\title{
Het carcinoom in de resectiemaag : een endoscopische en histologische studie
}

Citation for published version (APA):

Pop, P. (1983). Het carcinoom in de resectiemaag : een endoscopische en histologische studie. [Doctoral Thesis, Maastricht University]. Rijksuniversiteit Limburg. https://doi.org/10.26481/dis.19831104pp

Document status and date:

Published: 01/01/1983

DOI:

10.26481/dis.19831104pp

Document Version:

Publisher's PDF, also known as Version of record

\section{Please check the document version of this publication:}

- A submitted manuscript is the version of the article upon submission and before peer-review. There can be important differences between the submitted version and the official published version of record.

People interested in the research are advised to contact the author for the final version of the publication, or visit the DOI to the publisher's website.

- The final author version and the galley proof are versions of the publication after peer review.

- The final published version features the final layout of the paper including the volume, issue and page numbers.

Link to publication

\footnotetext{
General rights rights.

- You may freely distribute the URL identifying the publication in the public portal. please follow below link for the End User Agreement:

www.umlib.nl/taverne-license

Take down policy

If you believe that this document breaches copyright please contact us at:

repository@maastrichtuniversity.nl

providing details and we will investigate your claim.
}

Copyright and moral rights for the publications made accessible in the public portal are retained by the authors and/or other copyright owners and it is a condition of accessing publications that users recognise and abide by the legal requirements associated with these

- Users may download and print one copy of any publication from the public portal for the purpose of private study or research.

- You may not further distribute the material or use it for any profit-making activity or commercial gain

If the publication is distributed under the terms of Article $25 \mathrm{fa}$ of the Dutch Copyright Act, indicated by the "Taverne" license above, 


\section{Het carcinoom in de resectiemaag}

Een endoscopische en histologische studie

\section{Proefschrift}

Ter verkrijging van de graad van doctor in de geneeskunde aan de Rijksuniversiteit Limburg te Maastricht, op gezag van de Rector Magnificus Prof. Dr. H.C. Hemker, volgens besluit van het College van Dekanen in het openbaar te verdedigen in de aula van de universiteit op vrijdag 4 november 1983 des namiddags te vier uur

door

Peter Pop

geboren te Maastricht 
Promotores:

Prof.Dr. J.M. Greep

Prof.Dr. G.J.V. Swaen

Referenten:

Prof.Dr. J.A. Flendrig

Prof.Dr. A.J.Ch. Haex

Prof.Dr. F. Sturmans 


\section{Hoofdstuk 2.}

Literatuuroverzicht

2.1. Historisch overzicht maagoperaties

2.2. Maagstompcarcinoom, nomenclatuur en definitie

2.3. Frequentie van voorkomen van het maagstompcarcinoom

2.4. Maagstompcarcinoom en geslacht

2.5. Stompcarcinoom en de indicatie tot primaire operatie

2.6. Leeftijd van de patiënt op het moment van de diagnostiek van het maagstompcarcinoom; tijdsinterval tussen primaire operatie en diagnosestelling stompcarcinoom

2.7. Stompcarcinoom en primaire operatie

2.8. Macroscopie en microscopie van het stompcarcinoom

2.9. Pathogenese van het stompcarcinoom

2.10. Klinisch symptomatologie van het stompcarcinoom

2.11. Diagnostiek van het stompcarcinoom

2.12. Histologisch onderzoek van stoma- en corpusbiopsieèn van de geopereerde maag

2.12.1. Epitheliale dysplasie

2.13. Behandeling van het stompcarcinoom

Hoofdstuk 3.

Vraagstelling van het onderzoek

4.1. Patiëntengroepen

4.2. Onderzoekgegevens

4.2.1. Gegevens van de anamnese

4.2.2. Gegevens van de endoscopie

4.2.3. Gegevens van histologisch onderzoek

4.2.4. Gegevens van de ziektegeschiedenis

4.3. Statistische methoden

Endoscopisch en histologisch onderzoek van BII-magen, meer dan 10 jaar postoperatief, in verband met klachten, in de periode 1970 tot en met 1979

5.1. Gegevens van de anamnese

5.2. Gegevens van de endoscopie

5.3. Gegevens van histologisch onderzoek

5.4. Ziektegeschiedenis van de carcinoompatiënten

5.5. Samenvatting van de onderzoekgegevens 
Endoscopisch en histologisch onderzoek van BII-magen, meer dan 10 jaar postoperatief, in verband met klachten, in de periode 1980 tot en met 1982

6.1. Gegevens van de anamnese

6.2. Gegevens van de endoscopie

6.3. Gegevens van histologisch onderzoek

6.4. Ziektegeschiedenis van de carcinoompatiënten

6.5. Samenvatting van de onderzoekgegevens

Hoofdstuk 7.

7.1. Gegevens van de anamnese in de periode 1980 tot en met 1982

7.2. Gegevens van de endoscopie

7.3. Gegevens van histologisch onderzoek

7.4.1. Ziektegeschiedenis van de carcinoompatiënten

7.4.2. Ziektegeschiedenis vam de niet-carcinoompatiënten met endoscopisch afwijkende beelden

7.5. Samenvatting van de onderzoekgegevens

Hoofdstuk 8.

Endoscopisch en histologisch onderzoek van BI-magen, meer dan 10 jaar postoperatief, in verband met klachten, in de periode 1970 tot en met 1979

8.1. Gegevens van de anamnese

8.2. Gegevens van de endoscopie

57

8.3. Gegevens van histologisch onderzoek

8.4. Ziektegeschiedenis van de carcinoompatiënten

8.5. Samenvatting van de onderzoekgegevens

Hoofdstuk 9.

Endoscopisch en histologisch onderzoek van BI-magen, meer dan 10 jaar postoperatief, in verband met klachten, in de periode 1980 tot en met 1982

9.1. Gegevens van de anamnese

9.2. Gegevens van de endoscopie

9.3. Gegevens van histologisch onderzoek

9.4. Samenvatting van de onderzoekgegevens 
Endoscopisch en histologisch onderzoek van BI-magen, meer dan 10 jaar postoperatief, bij patiënten zonder klachten, in de periode 1980 tot en met 1982

10.1. Gegevens van de anamnese

10.2. Gegevens van de endoscopie

10.3. Gegevens van histologisch onderzoek

10.4. Samenvatting van de onderzoekgegevens van BII-magen, in verband met een bloeding, in de periode 1970 tot en met 1982

11.1. Gegevens van de anamnese

11.2. Gegevens van de endoscopie

11.3. Gegevens van histologisch onderzoek

11.4. Ziektegeschiedenis van de carcinoompatiënten.

11.5. Samenvatting van de onderzoekgegevens

Hoofdstuk 12.

Discussie

Hoofdstuk 13.

Conclusies

Discussion

Conclusions

Literatuurlijst

Dankwoord

Curriculum Vitae

Endoscopische beelden

Histologische beelden 


\section{Hoofdstuk 1}

\section{Inleiding}

Vanaf 1970 werden in Maastricht regelmatig patiènten met een BI- en BII-resectiemaaggeëndoscopieerd. Opvallend bij deze endoscopieen was de vrijwel steeds aanwezige gastritis ter hoogte van het stoma en het zeer regelmatig, vaak in grote hoeveelheden, voorkomen van gal in de restmaag. Carcinomen werden relatief frequent vastgesteld in de BII-maag, zelden in de BI-maag. In het algemeen bleek de prognose van het carcinoom in de BII-maag slecht te zijn.

Bij bestudering van de literatuur over het carcinoom van de geopereerdie maag, bleek er een aantal onduidelijkheden te bestaan:

- van de frequentie van voorkomen van het carcinoom van de geopereerde maag bleken de percentages sterk uiteen te lopen, varieerden van 1.3 tot $17.0 \%$, afhankelijk van de onderzochte patiëntenpopulaties;

- de prognose van patiënten, bij wie het stompcarcinoom gediagnostiseerd werd naar aanleiding van aanwezige klachten, bleek slecht te zijn; om deze reden werd geadviseerd patiënten, meer dan 10 jaar na een maagoperatie, regelmatig te screenen op het voorkomen van een carcinoom in de beginfase, teneinde de prognose van dit lijden te verbeteren;

- het bleek niet duidelijk te zijn, of het fenomeen matige dysplasie, dat bij histologisch onderzoek van met name stomabiopten nogal eens vastgesteld wordt, betekenis heeft in de zin van een premaligne afwijking, watuan strikte controle noodzakelijk is, om tijdig in een nog curatieve fase het stompcarcinoom te kunnen diagnostiseren.

Bestudering van een aantal operatieboeken wit de jaren vijftig leerde, dat er in dic periode in Maastricht ongeveer 100 patiënten per jaar een maagresectie ondergingen . In de loop der jaren werd de maagoperatie wrijwel steeds door dezelfde chirurgen verricht.

Aangezien de operatieboeken onvoldoende gegevens bevatten over de aard van het grondlijden, het type van de operatie enz., werden vervolgens statussen van individuele patiënten opgezocht. $\mathrm{B} \mathrm{ij}$ bestudering hiervan bleek, dat de BII-resectie het meest frequent werd uitgevoerd, vaak in verband met een ulcus duodenilijden, duidelijk meer bij mannen dan bij vrouwen. Het operatieverslag vermeldde bij deze chirurgen een uniforme methodiek, in praktisch alle gevallen werd een BII-resectie met retrocolische anastomose uitgevoerd.

In 1979 werd besloten nader onderzoek te verrichten naar de frequentie van voorkomen van het stompcarcinoom van de in Maastricht geopereerde patiënten, na te gaan of er vanuit deze populatie patiënten een groep "at risk" te selecteren zou zijn, bij wie in een symptoomloze fase endoscopie op het voorkomen van een stompcarcinoom zinvol zou zijn, om vita vroegdiagnostiek in een curatieve fase zinnige therapie te kunnen bieden. Tevens werd besloten te onderzocken of het histologische fenomeen matige dysplasie enige betekenis heeft als premaligne afwijking.

Via het Diagnostisch Centrum (een afdeling in het ziekenbuis, waarheen huisartsen patiënten verwijzen voor onderzoek met behulp van diagnostische faciliteiten wan het ziekenhuis) werden de huisartsen van Maastricht en omstreken op de hoogte gesteld van het feit, dat patienten meer dan 10 jaar na een maagresectie, mogelijk een verhoogde kans hebben op de ontwikkeling wan een stompcarcinoom; hen werd de mogelijkheid geboden hiervoor in aanmerking komende patiënten te verwijzen voor endoscopisch onderzoek.

In het ziekenhuis werkzame specialisten werden eveneens op de hoogte gebracht wan gepland onderzoek. 


\section{Hoofdstuk 2}

\section{Literatuur-overzicht}

\subsection{Historisch overzicht maagoperaties}

Ongeveer 100 jaar geleden, in 1881, werrichtte Billroth de eerste succesvolle maagresectie. Hij legde een gastroduodenostomie aan bij een patiënte met een stenoserend antrumcarcinoom. Bij een patiént met een niet te reseceren stenoserend carcinoom van het antrum legde Wölfler in september 1881 een gastrojejunostomie aan. De eerste maagresectie in verband met een peptisch ulcuslijden vond plaats in 1882, het jaar waarin Rydygier een gastroduodenostomie volgens Billroth verrichtte bij een patiẻnt met een stenoserend ulcus ter hoogte van de pylorus. Door Billroth werd in 1885 de maagresectie met gastrojejunostomie (Billroth-II resectie) aangegeven als tweede mogelijkheid wan chirurgische behandeling van het benigne ulcuslijden. De hoge mortaliteit was er de oorzaak van, dat de maagresectie als behandeling van het goedaardig ulcuslijden niet populair werd. In de eerste vier decennia van deze eeuw bleef de gastroenterostomie de voorkeursbehandeling van het peptisch ulcuslijden. Naar aanleiding van een toenemend aantal recidief ulcera ter hoogte wan het stoma nam rond 1920 het aantal uitgevoerde gastroenterostomieên af, werd deze operatie vervangen door de $2 / 3$ maagresectie met gastrojejunostomie, zoals reeds in 1914 geadviseerd werd door Schnitzler en in 1918 door Finsterer. In verband met de post-gastrectomieklachten werden modificaties van de klassieke BII-resectie reeds aangegeven door von Hacker (retrocolische gastrojejunostomie) in 1885 en Braun (een entero-enterostoma op het laagste punt tussen afferente en efferente jejunumlis) in 1892 . In de loop der jaren is zeker een twintigtal modificaties van de BII-resectie in de literatuur aangegeven (Rehner 1975). De Billroth-II resectie vindt tot het midden van de jaren zeventig in ruime mate toepassing als chirurgische therapie van het ongecompliceerde ulcus pepticumlijden.

Rond de jaren veertig van deze eeuw ontstond er van chirurgische zijde belangstelling voor de nervus vagus chirurgie als de therapie van het peptisch ulcuslijden. Dragstedt en Owens behandelden in 1943 patiënten met een ulcus duodeni met een truncale vagotomie. Als gevolg van de hierop frequent volgende maag-atonie met functionele pylorusstenose vond een doorbraak van deze operatieprocedure pas plaats na ontwikkeling van de selectieve vagotomie.

Jackson en Frankson beschreven in 1948 een selectieve vagotomie met gastroenterostomie, Weinberg combineerde in 1951 een truncale vagotomie met een pyloroplastiek en Harkins beschreef in 1960 een selectieve vagotomie met antrectomie. De door Holle in 1965 beschreven selectieve proximale vagotomie (eveneens genoemd highly selective vagotomy en pariëtale celdenervatie) sluit de rij wan chirurgische ingrepen bij patiënten met een ulcus pepticum.

In het begin van de jaren zeventig is er een duidelijke toename te zien van het aantal vagotomieen en een hiermee corresponderende afname van het aantal resecties bij het peptisch ulcuslijden. $V$ anaf 1977 is er cen duidelijke daling te constateren in het aantal maagoperaties (resecties en vagotomieën) door een afname wan het antal ullcusperforaties (Busman, 1983) en door het verschijnen wan geneesmiddelen (histamine II receptorantagonisten) die een significante verbetering betekenen van de conservatieve behandeling van het ulcus pepticum in vergelijking met de tol dan toe gebruikte medicatie van antacida en anticholinergica. In hoeverre het vanuit literaturgegevens meer bekend worden van het maagstompcarcinoom als late complicatie van de maagoperatie mede bijgedragen theeft tot het doen afnemen van het aantal maagresecties, is niet duidelijk.

\subsection{Maagstompcarcinoom, nomenclatuur en definitie}

Het carcinoom in de resimaag van patiënten, geopereerd in verband met een benigne peptisch ulcus, werd voor het eerst in 1926 gemeld door Beatson, Owens en Schwarz. Zij beschreven deze carcinomen in de gastroenterostomiemaag. In 1930 beschreef Eichelter voor het eerst een carcinoom ter hoogte van het stoma van een BII-resectiemaag bij een patiënt, geopereerd in verband met een benigne ulcus. Prinz en Konjetzny beschouwden in 1938 het carcinoom van de restmaag als een bijzondere vorm van maagcarcinoom, duidelijk te onderscheiden van het carcinoom-reci- 
dief in de primair ter behandeling van een carcinoom geopereerde maag. In een Bl-resectiemaag werd een carcinoom voor het eerst gemeld door Heinzel en Laque in 1954.

Het begrip maagstompcarcinoom wordt geintroduceerd en per definitie wordt gesteld, dat an twee voorwaarden dient te zijn voldaan (Helsingen en Hillestad 1956. Hebold 1958, Liavaag 1962, Gerstenberg e.a. 1965, Hilbe e.a. 1968):

- de maagoperatie in het verleden dient verricht te zijn in verband met een histologisch bevestigde goedaardige aandoening;

- het tijdsinterval tussen de eerste maggoperatie en de vaststelling van het carcinoom in de geopereerde maag moet tenminste vijf jaar bedragen (arbitrair gekozen termijn)

Het carcinoom in de mag na een tevoren uitgevoerde gastroenterostomie wordt door een aantal auteurs (Kootz 1967. Albert en Nowothy 1970, Peters e. a. 1974) in een aparte groep onderge. bracht. Anderen wermelden in hun studies over het maagstompcarcinoom eveneens carcinomen in de gastroenterostomiemaag. Morgenstern e.a. (1973) stellen voor een carcinoom in een rest. maag, optredend tenminste 20 jaar na een operatie in verband met een primair maagcarcinoom, eveneens te rekenen tot de stompcarcinomen.

\section{Commentar}

Volgens bovengenoemde definitie dient ieder carcinoom in de geopereerde matag, war dan ook gelocaliseerd, beschouwd te worden als een stompcarcinoom. Wanneer het stompcarcinoom niet alleen gezien wordt als na de operatie te zijn ontstaan, mar ook als gevolg van de operatie, kunmen de volgende opmerkingen worden gemaakt. Waar op grond van pathogenetische mechanismen, zoals gallige reflux, gedacht wordt aan het stoma als belangrijke predilektieplaats voor het ontstaan van een stompcarcinoom (zie: 2.9. Pathogenese van het stompcarcinoom, pagina 17), wordt in de literatuur geen aandacht besteed aan het uit deze gedachtengang voort vloeiende probleem van bijvoorbeeld een in de cardia van de restmaag gelocaliseerd carcinoom. Deze localisatie, ver verwijderd van het stoma, moet op zijn minst als atypisch beschouwd worden bij verondersteld aanwezige pathogenetische mechanismen zoals de gallige reflux. De vraag dient derhalve gesteld te worden of deze hoog in de maag gelocaliseerde carcinomen wel als echte stompcarcinomen beschouwd kunnen worden. Anderzijds kan de vraag opgeworpen worden, of de theorie over de gallige reflux als belangrijk pathogenetisch mechanisme voor het onstaan van het stompcarcinoom, wel valide is. Op grond van dierexperimenteel onderzoek (Dahm en Werner 1973, Langhans e.a. 1980) en klinische studies (Borg 1959, Werner e.a. 1975, Schumpelick e.a. 1979) wordt naast een eventuele invloed van voeding (nitrosaminen), bacteriën, zuurgraad van de maag e.d., de gallige reflux als van essentiële betekenis gezien voor het ontstaan van het stompcarcinoom. Naar deze opvatting dient het stoma gezien te worden als voorkeursplaats voor de ontwikkeling van een stompcarcinoom. Voor het hoog in de restmaag gelocaliseerde carcinoom dient rekening gehouden te worden met de mogelijkheid, dat genoemd pathogenetisch mechanisme hier niet verantwoordelijk is voor het ontstaan. Het hoog gelocaliseerde carcinoom in de restmaag zou dan als een "gewoon" maagcarcinoom kunnen worden gezien.

\subsection{Frequentie van voorkomen van het maagstompcarci- noom}

Waar in 1926 het carcinoom in de geopereerde maag als casuistische mededeling gemeld werd, is er sedert de jaren zestig sprake van een toenemende berichtgeving over deze als late complicatie van de maagoperatie te beschouwen aandoening. Terwijl de verzamelde literatuur in 1940 twin. tig patiënten meldt met een stompcarcinoom, is dit aantal in 1963328 , wordt in 1976 over 2546 patiënten met een maagstompcarcinoom melding gemaakt (Peitsch e.a. 1976). De toename in frequentie van voorkomen zal voor een belangrijk deel samenhangen met de toename van het aantal in het verleden verrichte maagoperaties. Het geattendeerd zijn op het probleem wan het maagstompcarcinoom, verbeterde diagnostische mogelijkheden (endoscopie), toename van het aantal obducties zullen mede hebben bijgedragen tot het toenemend aantal meldingen in de literatuur. Onduidelijk is of men te maken heeft met een echte toename van de incidentie dan wel met artefacten. 
Over de frequentie wn thet voorkomen van het stompcarcinoom (gedefinieerd als een nieuw ontdekt carcinoom in een mage meer dan vijf jaar tevoren geopereerd in verband met een histologisch bewezen goedaardige aandoening) wordt vanuit verschillende gezichtshoeken bericht (zie Tabel 2.1):

- vanuit de kliniek meldt de internist retrospectief het adatal stompcarcinomen in relatie tot het aantal onderzochte patiênten met een geopereerde maag (meestal in verband met maagklachten onderzocht); de chirurg meldt het aantal stompcarcinomen in relatie tot het totale aantal geopereerde maagcarcinomen;

- vanuit obductiestatistieken worden gegevens gemeld over het aantal stompcarcinomen in relatie tot het totaal aantal maagresecties in het obductiebestand over een bepaalde tijdsperiode;

Tabel 2.1. De frequentie van woorkomen van het stompcarcinoom vanuit verschillende gezichtshoeken bekeken

\begin{tabular}{|c|c|c|c|}
\hline auteurs & jaar & $\begin{array}{c}\text { aantal } \\
\text { patiënten }\end{array}$ & $\begin{array}{l}\text { o stomp- } \\
\text { carcinoom }\end{array}$ \\
\hline \multicolumn{4}{|c|}{ obductie onderzoek } \\
\hline $\begin{array}{l}\text { Külhimayere.a. } \\
\text { Hebold } \\
\text { Mörl } \\
\text { Hilbe e.a. } \\
\text { Stalsberg e.a. } \\
\text { Terjesene.al. } \\
\text { Peitsch e.a. } \\
\text { Grosse }\end{array}$ & $\begin{array}{l}1954 \\
1958 \\
1967 \\
1968 \\
1973 \\
1976 \\
1978 \\
1978\end{array}$ & $\begin{array}{r}363 \\
81 \\
300 \\
412 \\
630 \\
728 \\
315 \\
410\end{array}$ & $\begin{array}{r}10.6 \\
9.9 \\
8.3 \\
8.2 \\
8.7 \\
2.1 \\
7.1 \\
6.1\end{array}$ \\
\hline \multicolumn{4}{|c|}{ klinisch onderzoek } \\
\hline $\begin{array}{l}\text { Helsingen e.a. } \\
\text { Krause } \\
\text { Denk e.a. } \\
\text { Dragoni } \\
\text { Griesser e.a. } \\
\text { Kronberger e.a. } \\
\text { Dahme.a. } \\
\text { Nicholls } \\
\text { Clemençon e.a. } \\
\text { Rösch e.a. } \\
\text { Peitsch e.a. }\end{array}$ & $\begin{array}{l}1956 \\
1957 \\
1957 \\
1963 \\
1964 \\
1968 \\
1973 \\
1974 \\
1976 \\
1977 \\
1977\end{array}$ & $\begin{array}{r}303 \\
3611 \\
2488 \\
116 \\
580 \\
2624 \\
530 \\
5115 \\
534 \\
705 \\
302\end{array}$ & $\begin{array}{r}3.6 \\
7.7 \\
1.3 \\
7.8 \\
13.3 \\
1.0 \\
6.9 \\
0.6 \\
4.3 \\
2.0 \\
8.9\end{array}$ \\
\hline \multicolumn{4}{|c|}{ endoscopisch onderzoek } \\
\hline $\begin{array}{l}\text { Solumid e.a. } \\
\text { Reissiglea. } \\
\text { Domellof e.a. } \\
\text { Geile e.a. } \\
\text { Osnese.a. } \\
\text { Oscarson } \\
\text { Bosseckert e.a. }\end{array}$ & $\begin{array}{l}1976 \\
1976 \\
1977 \\
1977 \\
1977 \\
1978 \\
1979\end{array}$ & $\begin{array}{r}705 \\
494 \\
676 \\
808 \\
74 \\
364 \\
205\end{array}$ & $\begin{array}{r}6.8 \\
17.0 \\
2.1 \\
5.2 \\
17.6 \\
6.0 \\
17.0\end{array}$ \\
\hline \multicolumn{4}{|c|}{ endoscopisch onderzoek prospectief } \\
\hline $\begin{array}{l}\text { Ewerthe.a. } \\
\text { Siwage e.a. } \\
\text { Geboese.a. } \\
\text { Stokkeland e.a. } \\
\text { Offerhaus e.a. }\end{array}$ & $\begin{array}{l}1978 \\
1979 \\
1980 \\
1981 \\
1982\end{array}$ & $\begin{array}{l}106 \\
63 \\
56 \\
108 \\
504\end{array}$ & $\begin{array}{l}0.0 \\
0.0 \\
8.9 \\
0.9 \\
1.6\end{array}$ \\
\hline
\end{tabular}

- in retrospectief onderzoek worden patiënten 5 tot 40 jaar postoperatief eenmalig endoscopisch bekeken en wordt het aantal stompcarcinomen gemeld;

- in prospectieve studies wordt een aantal patiënten postoperatief vervolgd (meestal pas geruime tijd na de operatie!) en periodiek endoscopisch gecontroleerd op het voorkomen van als precancereus beschouwde slijmvliesafwijkingen en stompcarcinoom. 
Het zal dan ook duidelijk zijn dat uit verschillende onderzoeken naar woren komende frequen ties van voorkomen van het stompcarcinoom sterk varièren, in directe afhankelijkheid van de samenstelling van de onderzochte patientenpopulaties. Stokkeland e.a. (1981) vermelden in een prospectieve studie $0.9 \%$ stompcarcinomen, Geboes e.a. (1980) $8.9 \%$; in klinische studies worden percentages vermeld variërend van 0.6 tot $13.3 \%$, terwijl vanuilt obductiestatistieken percentages naar voren komen van 2.1 tot $10.6 \%$ (zie Tabel 2.1.).

Op grond van deze gegevens worden uitspraken gedaan over het al dan niet in verhoogde frequentie voorkomen van het maagstompcarcinoom in vergelijking met het maagcarcinoom bij niet wan tevoren geopereerde personen; adviezen wordlen gegeven over het al dan niet wenselijk zijn wan periodiek endoscopisch controle-onderzoek van de geopereerde maag.

\section{Commentaar}

Het sterk uiteenlopen van percentages per categorie onderzochte patiënten doet vermoeden, dat in deze onderzoeken methodische fouten gemaakt zijn. Daar verondersteld mag worden, dat prospectieve en retrospectieve studies in hun opzet kritisch bekeken zijn en wetenschappelijk gezien van meer belang zijn dan klinische mededelingen, lijkt het zinvol deze groepen nader te bekijken.

Uitgegaan wordt van de eisen die gesteld dienen te worden om in prospectieve en retrospectieve studies vergelijkingen mogelijk te maken:

- voldoend groot aantal patiënten;

- voldoend lange postoperatieve periode;

- voldoend lange observatieperiode (prospectief onderzoek);

patiënten geopereerd volgens dezelfde methode;

- patiënten met hetzelfcle grondlijden waarvoor operatie geindiceerd was;

- vergelijking van patiëntengroepen met hetzelfde grondlijden; operatief en conservatief behandeld.

Een ruim voldoend aantal patiënten dient aanwezig te zijn, aangezien o.a. door overlijden en het niet genegen zijn om aan onderzoek deel te nemen, met een relatief groot percentage uitval rekening gehouden dient te worden. Bij retrospectieve studies moet de postoperatieve periode voldoende lang zijn, daar het interval tussen operatie en het optreden van een maagstompcarcinoom tenminste 20 jaar bedratat (zie Tabel 2.4.: Stompcarcinoom en het gemiddeld interval tussen primaire operatie en diagnosestelling, blz. 14). Prospectieve studies moeten tijdig alanvangen en zich uitstrekken over een voldoend aantal jaren, teneinde uitspraken te kunnen doen over de betekenis wan als precancereus beschouwde afwijkingen en de ontwikkeling hiervan tot een carcinoom. In verband met verondersteld aanwezige pathogenetische mechanismen zoals galreflux dienen patiënten volgens eenzelfde methode geopereerd te zijn (BI- of BIl-maag, zonder of met Braunse anastomose). Het primaire lijden moet bekend zijn (ulcus ventriculi, ulcus duodeni enz.), gegevens over histologisch onderzoek van het operatiepreparaat zijn wenselijk. Het lijkt eveneens noodzakelijk te beschikken over een vergelijkbare groep patiênten met dezelfde primaire aandoening, waarvan de behandeling conservatief geweest is, evenals over cen controlegroep, teneinde de carcinoomfrequentie in deze groepen te kunnen vergelijken. Duidelijke definities dienen aanwezig te zijn ten aanzien van het stompcarcinoom, veronderstelde precancereuze afwijkingen enz.

Bij bestudering van in de literatuur vermelde onderzoeken naar de frequentie van voorkomen van het stompcarcinoom kan een aantal opmerkingen worden gemaakt:

- de definitie van het stompcarcinoom (carcinoom in de geopereerde maag, meer dan 5 jaar na operatie, waarbij de basisaandoening histologisch bewezen goedaardig dient geweest te zijn) wordt door een ieder gevolgd. De gastro-enterostomiemaag wordt door sommigen wel, door anderen niet in series onderzochte patiénten opgenomen;

als stompcarcinoom worden alle carcinomen, ontstaan in de geopereerde matg beschouwd. Wanneer het stompcarcinoom gezien wordt als ten gevolge van de operatie ontstan en de galreflux beschouwd wordt als belangrijk pathogenetisch mechanisme, komt de vratag naar voren of het cardiacarcinoom als een stompcarcinoom beschouwd mag worden;

- in weel onderzoeken worden zowel BI-als BII-magen bekeken. In het algemeen wordt verondersteld dat de BII-resectiemaag een groter risico heeft voor het ontwikkelen van een stompcarcinoom;

- in de meeste studies wordt niet aangegeven of de hierin opgenomen patiënten volgens dezelfde methode geopereerd werden; 
- vaak blijk het miet mogelijk oude gegevens wan patienten te achterhalen (primaire indicatie tot operatic, operatie-methode enz.);

- in de studies ontbreken vaak gegevens over de overleden patiënten (geen obductiegegevens. bekend, patient uit het oog verloren, veronderstelde diagnose bij overlijden enz.);

- in retrospecticve studies, warin de frequenties van het stompcarcinoom worden aangegeven, kan uiteraard geen rekening gehouden worden met de in de toekomst nog zich ontwikkelende stompcarcinomen van de nog levende patiènten;

- prospectieve studies bestaan vaak uit een of enkele endoscopieën over een betrekkelijk korte tijdsduur, meer dan 20 tot 25 jaar postoperatief; dit zijn dus geen prospectieve studies in de eigenlijke betekenis van het woord;

- studies vinden regelmatig plaats in universitaire klinieken, waar sprake is van een concentratie van probleempatienten uit een verre omgeving.

Bovenstaande opmerkingen kunnen worden geillustreerd aan de hand van het artikel "Hoe vaak komt maagstompcarcinoom voor?" van Welvaart en Warnsinck (1982). Op grond van voorgaande overwegingen kunnen de wolgende kanttekeningen worden gemaakt:

- van de 130 patiënten (uit een totaal van 264 patiënten die in de periode van 1950 tot 1955 een BII-resectie ondergingen), die overleden zijn wordt gemeld, dat 5 patiënten overleden aan de gevolgen van een stompcarcinoom. Niet vermeld wordt of het hier obductiegegevens betreft met histologische bevestiging van deze diagnose. Van de overige 125 overleden patiënten worden geen gegevens vermeld (oorzalk van overlijden, obductiebevindingen en dergelijke). De stellingname van de auteurs dat het "onwarschijnlijk is dat een dramatisch ziektebeloop, zoals men dat verwacht bij lijders aan een stompearcinoom, door de behandelend arts zou zijn gemist en wanneer de patiënt is overleden, een onjuiste doodsoorzaak zou zijn opgegeven", kan bekritiseerd worden via de opmerking dat een stompcarcinoom in beginfase aanwezig kan geweest zijn bij patiënten overleden aan de gevolgen van andere ziekten. Eveneens is het mogelijk dat bij overleden patiënten, bij wie geen obductie, geen uitgebreid voorafgaand onderzoek en dergelijke verricht is, niet correcte gegevens over de waarschijnlijke doodsoorzaak gemeld zijn (veel artsen zijn nauwelijks op de hoogte wan het voorkomen van stompcarcinomen in de resectiemaag);

- dat de vage klachten van 42 van de 127 nog levende patiënten zonder aarzeling kunnen worden toegeschreven aan de vroegere resectie, is mogelijk anamnestisch aannemelijk. Dit werd niet zeker gesteld wia endoscopisch onderzoek, ter uitsluiting van een stompcarcinoom;

- de mededeling dat het hoogst onwaarschijnlijk is, dat in de serie patiënten die nog in leven zijn, er patiënten voorkomen, die alsnog een stompcarcinoom ontwikkelen, danwel met een stompcarcinoom zonder bijbehorende klachten leven, is beslist onjuist. Een stompcarcinoom in een beginfase geeft doorgaans geen klachten; stompcarcinomen komen uiteraard ook later dan 25 tot 30 jaar postoperatief voor.

De conclusic dat de uitkomsten van dit non-informatief onderzoek geen steun geven aan de bewering, dat de kans op een stompcarcinoom duidelijk hoger is, dan de kans dat een gezond individu een maagcarcinoom krijgt, is juist. Echter kunnen bij de in dit onderzoek gehanteerde getallen wragtekens geplaatst worden, waardoor de betrouwbaarheid van de berekende percentages dubieus wordt.

\subsection{Maagstompcarcinoom en geslacht}

Wanneer in de literatuur series patiënten met een maagstompcarcinoom vermeld worden, blijkt deze aandoening veel frequenter bij de man dan bij de wroww vastgesteld te zijn (zie Tabel 2.2.). In grotere series (meer dan 50 patiënten) varieert de man-vrouw verhouding van $6.1: 1$ tot $10.2: 1$.

\section{Commentar}

Vrijwel alle auteurs wijzen er op, dat deze vaststelling in samenhang gezien moet worden met het feit, dat magresecties in verband met een ulcuslijden bij de man veel frequenter dan bij de vrouw uitgevoerd worden. In de verschillende publicaties worden hiervan echter geen verdere gegevens vermeld. 
Tabel 2.2. Stompcarcinoom bij mannen en vrouwen

\begin{tabular}{|c|c|c|c|}
\hline auteur/geslacht & $\operatorname{man}$ & vrouw & toragl \\
\hline Hammar 1976 & 51 & 5 & 56 \\
\hline Wolf e.an. 1977 & 33 & 2 & 35 \\
\hline de Boer e.a. 1978 & 86 & 14 & 100 \\
\hline Radomskye.a. 1978 & 36 & 4 & 40 \\
\hline Dahme.a. 1979 & 81 & 12 & 93 \\
\hline Schönlebene.a. 1979 & 30 & 6 & 36 \\
\hline Tautenhahn e.a. 1979 & 32 & 4 & 36 \\
\hline Hünicke e.a. 1980 & 19 & 1 & 20 \\
\hline Haemers e.a. 1980 & 20 & 0 & 20 \\
\hline Rauwerda 1980 & 118 & 16 & 134 \\
\hline Orlando e.a. 1981 & 16 & 1 & 17 \\
\hline Doughertye.a. 1982 & 20 & 1 & 21 \\
\hline
\end{tabular}

\subsection{Stompcarcinoom en de indicatie tot primaire operatie}

Sommige auteurs geven aan dat het stompcarcinoom vaker gezien wordt bij patiënten die primair geopereerd werden in verband met een ulcus ventriculi (Helsingen e.a. 1956, Boeckl e.a. 1963, Griesser e.a. 1964, Kronberger e.a. 1968, Nicholls 1974, Schmid 1977, Radomsky c.a. 1978), anderen stellen dat er geen duidelijk voorkeursrelatie bestaat met het ulcus duodeni of het ulcus ventriculi (Freedman e.a. 1954, Krause 1957, Berkowitze.a. 1959, Stalsberg e.a. 1971, Saegesser e.a. 1972, Peitsch e.a. 1976, Domellö e.a. 1977), terwij] er eveneens mededelingen zijn, dat het ulcus duodenilijden frequenter gepaard gaat met een stompcarcinoom dat het ulcus ventriculilijden (Hammar 1976, Hünicke e.a. 1980, Langhans e.a. 1980, Mozsik e.a. 1980).

\section{Commentaar}

In het algemeen worden er in de bestudeerde literatuur geen gegevens vermeld over de groep geopereerde patiënten, waaruit de stompcarcinoompatiënten afkomstig zijn; met name ontbreken hierbij de gegevens over indicatie tot primaire operatie, waarbij de verhouding van de antallen patiënten ulcus duodeni : ulcus ventriculi van belang is. Een andere complicerende factor bij de beoordeling van een eventuele voorkeursrelatie stompcarcinoom/UD-UV-lijden is gelegen in het feit, dat bij patiënten met een ulcus duodenilijden frequenter een BII-resectie, bij patiënten met een ulcus ventriculi frequenter een BI-resectie uitgevoerd wordt, waarbij in het algemeen gesteld wordt, dat de kans op ontwikkeling van een stompcarcinoom groter geacht mag worden bij een BII-resectiemaag dan bij een BI-resectiemaag.

Waar in het algemeen het interval tussen primaire operatie en het stompcarcinoom 20 jaar of lan. ger blijkt te zijn, zullen slijmvliesveranderingen ter hoogte van de restmaag in deze periode van doorslaggevende betekenis kunnen zijn. Het feit, dat het tijdsinterval langer is naarmate de primaire operatie op jongere leeftijd heeft plaatsgevonden, wijst ook in deze richting (de Boer e.a. 1978, Dougherty e.a. 1982). Bij een operatie op oudere leeftijd (tijdsinterval in het algemeen korter van duur) zullen slijmvliesafwijkingen als basis voor de ontwikkeling van een stompcarcinoom in zekere mate aanwezig zijn. Wanneer ook op oudere leeftijd slijmvliesafwijkingen in de zin van een gastritis frequenter voorkomen bij patięnten met een ulcus ventriculi dan bij patiënten met een ulcus duodenilijden, zal mogelijk bij deze groep patiënten sprake zijn van een voorkeursrelatie maagstompcarcinoom - ulcus ventriculilijden op mogelijke betrekkelijk korte termijn (vergeleken met het tijdsinterval van de jongere patiënt). Een stompcarcinoom bij de oudere patiënt met een ulcus duodenilijden zonder slijmvliesafwijkingen op het moment wan de operatie, zal zich dan eventueel ontwikkelen op een langere termijn (vergelijkbaar met het intervall bij de jongere patiënt). Gegevens hierover zijn in de literatuur niet te vinden. 


\subsection{Leeftijd van de patiënt op het moment van de diagnostiek van het stompcarcinoom; tijdsinterval tussen primaire opera- tie en diagnosestelling stompcarcinoom}

In de literatuur zijn de gegevens ten aanzien van de leeftijd van de patiènt waarop het stompcarcinoom zich manifesteert en het tijdsinterval tussen primaire operatie en diagnosestelling van het stompcarcinoom wrijwel gellikluidend. De gemiddelde leeftijd, waarop het stompcarcinoom gediagnostiseerd wordt warieert in de diverse studies van 59.9 tot 70.3 jaar (zie Tabel 2.3.) en komt volgens de diverse auteurs overeen met de gemiddelde leeftijd, waarop ook in hun kliniek het "gewone" maagcarcinoom zich presenteert.

Tabel 2.3. Stompcarcinoom en de gemiddelde leeftijd bij diagnosestelling

\begin{tabular}{|c|c|c|}
\hline awteur & $\begin{array}{l}\text { gemiddelde leeftijd } \\
\text { in jaren }\end{array}$ & $\begin{array}{l}\text { aantal } \\
\text { stompcarcinomen }\end{array}$ \\
\hline Terjesene.a. 1976 & 66.0 & 36 \\
\hline Hammar 1976 & $58.8^{*}-63.6^{*}-67.7^{* *}$ & $9 * 22 *-34 * *$ \\
\hline de Boer e.a. 1978 & 65,0 & 100 \\
\hline Orosse 1978 & 60.0 & 25 \\
\hline Radoms ky e.a. 1978 & 61.5 & 40 \\
\hline Dahme.a. 1979 & 63.6 & 93 \\
\hline Schónleben e.a. 1979 & 59.9 & 36 \\
\hline Tautenhahne.a. 1979 & 64.9 & 36 \\
\hline Hünicke. a. 1980 & 60.3 & 20 \\
\hline Mozsik e.a. 1980 & 60.1 & 28 \\
\hline Otlando e.a. 1981 & 70.3 & 17 \\
\hline Dotugherty a. 1982 & 65.7 & 21 \\
\hline
\end{tabular}

$*=$ precancere uze verandering $\quad * *$ vroegcarcinoom

* * infiltratief groeniend carcinoom

Het tijdsinterval tussen de primaire operatie en het manifest wor ten van het stompcarcinoom varieert van 18.7 tot 28.5 jaar (zie Tabel 2.4.).

Hierbij wordt door verschillende auteurs aangetekend, dat het tijdsinterval langer is, naar mate de patiênt op jongere leeftijd de primaire operatie ondergaan heeft. Tot 15 jaar na de primaire operatie blijft bet risico op de ontwikkeling wan een stompcarcinoom beperkt, na 15 jaar is er sprake van een duidelijke toename van dit risico (Stalsberg e.a. 1972, Clemençon e.a. 1975, Schmid e.a. 1976, Peitsch e.a. 1976, de Boer e.a. 1978).

Tabel 2.4. Stonpearcinoom en het gemiddeld interval tussen primaire operatie en diagnosestelling

\begin{tabular}{|c|c|c|}
\hline ancer & $\begin{array}{l}\text { gemiddeld interval } \\
\text { in jaren }\end{array}$ & $\begin{array}{l}\text { armial } \\
\text { stompcarcinomen }\end{array}$ \\
\hline Terjesene.a. 1976 & 28.5 & 36 \\
\hline Kratochvil a. 1977 & 250 & 12 \\
\hline Schnid e.a. 1977 & 24.0 & 44 \\
\hline Wolfe.a. 1977 & 21.0 & 35 \\
\hline de Bower ea. 1978 & 25.1 & 100 \\
\hline Grosse 1978 & 21.5 & 25 \\
\hline Radomskye.a. 1978 & 27.8 & 40 \\
\hline Dahme e. 1979 & 22.4 & 93 \\
\hline Schönleberte. 1979 & 24.4 & 36 \\
\hline Thutenhabne.a. 1979 & 18.9 & 36 \\
\hline Hunicke ext 1980 & 27.9 & 20 \\
\hline Langhans e.a. 1980 & 25.5 & 44 \\
\hline Hamerse. 1980 & 23.0 & 20 \\
\hline Ratuwerda 1980 & 25.1 & 134 \\
\hline Orlandora 1981 & 18.7 & 17 \\
\hline Dougherty e. 1982 & 26.9 & 21 \\
\hline
\end{tabular}




\subsection{Stompcarcinoom en primaire operatie}

Het merendeel van de literatuur, handelend over het voorkomen van een carcinoom in de geopereerde maag, meldt dat het carcinoom bij woorkeur voorkomt in de BII-resectiemaag en gastroenterostomiemaag (Kühlmayer e.a. 1954, Gerstenberg e.a. 1965, Morgenstern e.a. 1973. Böttcher e.a. 1973, Dony e.a. 1973, Peters e.a. 1974, Peitsch e.a. 1976). Enkele malen wordt het even frequent voorkomen van het carcinoom in de BI-en BII-resectiemaag vermeld (Schmid 1977, de Boer e.a. 1978). Een enkele maal wordt gewezen op het feit, dat een bepaald type BIIresectiemaag (antecolische BII-maag met Braunse anastomose) ten gevolge wan een verminderde reflux van gallige darminhoud minder risico zou bieden op de ontwikkeling van een stompcarcinoom (Dahm e.a. 1976).

Hünicke e.a. (1980) melden bij 20 patiënten met een stompcarcinoom vijfmaal een carcinoom in een BII-resectiemaag, antecolisch aangelegd met Braunse anastomose (gegevens over het aantal patiënten, geopereerd volgens deze methode, in vergelijking met aantallen patiënten, geopereerd volgens andere methoden, ontbreken in deze publicatie).

\section{Commentaar}

Over de literatuur ten aanzien van de eventuele relatie stompcarcinoom primaire operatieprocedure kunnen de volgende kanttekeningen worden gemaakt:

in een aantal publicaties over het stompcarcinoom wordt geen melding gemaakt of het carcinomen betreft in een BI-maag of BII-maag, eventueel gastroenterostomiemaag (Hilbe e.a. 1968, Wolf e.a. 1977, Voigtsberger e.a. 1977, Grosse 1978);

- in diverse publicaties worden absolute getallen genoemd van aantallen stompcarcinomen in BI- en BII-resectiemagen, niet aangegeven wordt het aantal oorspronkelijk uitgevoerde BI- en BII-maagresecties en het hieruit berekende percentage stompcarcinomen in de BI-en BIImaag (Hilbe e.a. 1968, Hammar 1976, Osnes e.a. 1977, de Boer e.a. 1978, Eberlein e.a. 1978, Grosse 1978, Dahm e.a. 1979, Haemers e.a. 1980, Hünicke e.a. 1980, Orlando e.a. 1981, Langhans e.a. 1981, Dougherty e.a. 1982);

in publicaties over het stompcarcinoom worden in het algemeen weinig gegevens vermeld over de localisatie van het stompcarcinoom (Hilbe e.a. 1968 . Schmid e.a. 1976, Kratochvil e.a. 1977, Grüngreiff e.a. 1978, Dahm e.a. 1979, Giacosa e.a. 1979, Nicholls e.a. 1979, Schwamberger e.a. 1979 , Haemers e.a. 1980, Mozsik e.a. 1980). Uitgaande van de veronderstelling dat de gallige reflux een duidelijke pathogenetisch moment vormt, kan het stoma gezien worden als predilektieplaats voor het ontstaan van dit carcinoom. Eventuele verschillen in localisatie van het stompcarcinoom in de BI- en BII-maag zouden kunnen wijzen op verschillende pathogenetische mechanismen (alkalische reflux-stomacarcinoom in de BII-maag, andere mechanismen in BI-maag, mogelijk vergelijkbaar met mechanismen, aanleiding tot de ontwikkeling van een carcinoom in de niet geopereerde maag);

- in publicaties worden van patiënten, geopereerd in een begrensde tijdsperiode, stompcarcinomen in Bl- en Bll-magen gemeld (Domellöf e.a. 1976, Ewerth e.a. 1978 , Savage e.a. 1979, Bähr e.a. 1980).

Er wordt geen rekening gehouden met het feit dat eventueel op grond van hetzelfde pathogenetische mechanisme (gallige reflux) in de BI-maag (minder gallige reflux dan in de BII-maag) het stompcarcinoom op een later tijdstip tof ontwikkeling zal komen. Overigens wordt op grond van deze veronderstelling (ernst van gallige reflux bepaalt al dan miet het optreden van een stompcarcinoom) in de groep BII-resectiemagen vrijwel nooit aangegeven volgens welke procedure de operatie plaatsgevonden heeft (retrocolische BII-maag versus antecolische BIImaag met Braunse anastomose). Verwacht mag worden dat resectiemagen met cen geringe reflux (antecolische BII-maag met Braunse anastomose) minder risico bieden op de ontwikkeling van een stompcarcinoom. Wanneer er aan de ontwikkeling van een stompcarcinoom in de BI-en BII-maag eventueel verschillende pathogenetische mechanismen ten grondslag liggen, dient eveneens rekening gehouden te worden met de mogelijkheid van een tijdsinterval van wisselende lengte.

\subsection{Macroscopie en microscopie van het stompcarcinoom}

Naar macroscopische verschijningsvormen kan er vrijwel steeds gesproken worden van een van 
de volgende drie manifestaties van het carcinoum:

- eem ulcererende vorm;

- cen polipoild grouende vorm;

- een infultratief groeiende vorm.

Op grond wan het verondersteide aanwezige pathogenetische mechanisme galreflux mag verwacht worden dat het stoma van de restmaag een voorkeurslocalisatie is. In de literatuur wordt de anastomose relatief frequent genoemd als plaats van voorkomen van het carcinoom (zie Tabel 2.5.). De cardiaregio wordt regelmatig genoemd als plaats van woorkomen van het carcinoom in de restmaag. Op grond van overwegingen ten aanzien van pathogenetische mechanismen, kan men zich afvragen of het in de cardia gelocaliseerde carcinoom van de restmaag beschouwd mag worden als een carcinoom, ontstaan in relatie met de resectie, danwel dat hier sprake is van een carcinoom, vergelijkbaar met het carcinoom in de niet geopereerde maag, de ontstaanswijze betreffende. Van deze problematiek wordt in de literatuur geen meliding gemaakt.

Bij aan aantal patienten is het, gezien de uitgebreidheid van het carcinoom, niet mogelijk de primaire localisatie in de maag te bepalen. Tabel 2.5. vermeldt de localisatie van het carcinoom in de restmaag in percentages, zoals in de literatuur door enkele auteurs aangegeven.

Tabel 2.5. Localisatie van het stompcarcinoom in $\%$ in de restmaag

\begin{tabular}{|c|c|c|c|c|c|c|}
\hline auteur & adntal & $\begin{array}{c}\text { srom } \\
\%\end{array}$ & $\begin{array}{c}\text { stomat } \\
\text { corpus } \\
\%\end{array}$ & corpus & $\begin{array}{c}\text { cardia } \\
\%\end{array}$ & $\begin{array}{c}\text { gehele } \\
\text { madg } \\
\%\end{array}$ \\
\hline Schonlobena. a. 1979 & 36 & 55.6 & & & 22.2 & 222 \\
\hline Radomskye.a. 1978 & 40 & 45.0 & & & 20.0 & 35.0 \\
\hline de Boer e. $\llbracket 978$ & 100 & 40.0 & 23.0 & $\sharp 2.0$ & 14.0 & 11.0 \\
\hline Tautenhahne.a. 1979 & 36 & 50.0 & & 5.6 & 11.1 & 33.3 \\
\hline Hünicke.a. 1980 & 20 & 55.0 & & & 10.0 & 35.0 \\
\hline Langharnse.a. 1980 & 44 & 45.4 & & & 27.3 & 27.3 \\
\hline Peitsch"e.a. 1976 & 1400 & 29.4 & & 34.6 & 13.3 & 22.7 \\
\hline
\end{tabular}

* literatuurstudie:

Bestudering van de literatuur op histologische kwalificatie van het carcinoom leert, dat de carcinomen in een a antal publicaties geklassificeerd worden naar beschrijuend histologische typen zoals adenocarcinoom, papillaircarcinoom, solide carcinoom, scirreus carcinoom en coloüdcarcinoom. In een aantal artikelen wordt de indeling van Lauren (1965) aangehouden: intestinaal en diffuus carcinoom. Met de indeling van Lauren is een betere korrelatie met de klinische parameters mogelijk. In het algemeen zijn patienten met een diffuus carcinoom iets jonger, de prognose is slechter; polipeus groeiende carcinomen blijken meer van het intestinale type, infiltrerende carcinomen meer van het diffuse type te zijn. Intestinale metaplasic wordt frequent in de directe omgeving van het carcinoom en ook vrij uitgebreid ter hoogte van de normale mucosa gezien bij patiënten met een intestinaal carcinoom, hetgeen bij een diffuus carcinoom duidelijk minder frequent het geval is.

De Boer e.a. (1978) en Schmid (1977) geven een indeling naar beschrijvend histologische types. Het slecht gedifferentieerde adenocarcinoom blijkt het meest frequent aanwezig te zijn. Rauwerda (1980) geeft van 134 patiënten de volgende indeling: adenocarcinoom, variërend van hoog tot slecht gedifferentieerd bij 127 patiënten, ongedifferentieerd carcinoom bij 6 patiënten, leiomyosarcoom bij 1 patiënt. Hammar (1976) geeft van 56 patiënten met een stompcarcinoom een indeling volgens Lauren: 27 patienten tonen een stompcarcinoom van het intestinale type, 29 patienten een carcinoom van het diffuse type.

\section{Commentaar}

Wanneer in de literatuur de localisatie van het stompcarcinoom in de restmaag wordt beschreven, geeft men hierbij onder andere aan dat het stoma frequent de plaats is waar een stompcarcinoon voorkomt. De cardia wordt eveneens regelmatig vermeld als primaire regio van het stompcarcinoom. Waar in de meeste artikelen als een van de belangrijke pathogenetische mechanismen, ten grondslag liggend aan het ontstaan van het stompcarcinoom, de reflux van gallig materiaal vanuit de dunne darm naar voren gebracht wordt, is het opvallend, dat bij de vermelding van de cardia als een van de plaatsen van primaire localisatie van het stompcarcinoom, geen na- 
der commentaar gegeven wordt. Wanneer immers de gallige refiux een belangrijke rol zou spelen bij het naar voren doen komen wan slijmvliesveranderingen, witeindelijk resulterend in een stompcarcinoom, is te verwachten dat het stomaslijmvlies, door imnig contact met gereflucteerd gallig materiaal, in eerste instantie veranderingen zal laten zien in de richting van een stompcarcinoom. Het cardiaslijmvlies zou hiervoor nauwelijks in anmerking kunnen komen. Experimenten met proefdieren (Dahm en Werner 1973, Langhans e.a. 1980) wijzen op het stoma van de geopereerde maag als exclusieve plaats van voorkomen van het stompcarcinoom ten gevolge van intens contact stomaslijmvlies-gallig materiaal, al dan niet in mede-aanwezigheid van nitrosaminen.

Alhoewel in de literaturur bij de beschrijving van de microscopie van maagcarcinomen de voordelen van de indeling volgens Lauren in intestinale en diffuse typen carcinoom gemelld worden als goed correlerend met een aantal klinische parameters, wordt bij de beschrijving van de microscopie van stompcarcinomen in grotere series opvallend weinig van deze indeling gebruik gemaakt.

\subsection{Pathogenese van het stompcarcinoom}

Ten aanzien van de pathogenese van het stompcarcinoom kunnen de in de literatuur narar voren komende hypothesen als volgt worden samengevat:

- beschadiging van de mucosabarrière door gallige reflux;

- stomaontsteking door epitheelirritatie;

- chronisch atrofische gastritis met anaciditeit;

- carcinogenen (nitrosaminen), vanuit voedsel, speeksel e.d. (nitraten, nitrieten) ontstaan via bacteriële interactie bij anaciditeit wan de maagrest.

Dierexperimenteel onderzoek geeft ondersteuning aan deze hypothesen. Dahm en Werner (1975) beschrijven proeven met Wistarratten: drie groepen dieren (BI-maag, BII-maag, niet geopereerde maag) krijgen ad libitum drinkwater met nitrosoguanidine ( $\mathrm{N}-\mathrm{Methyl}-\mathrm{N}$ '- Nitro- $\mathrm{N}-\mathrm{Ni}$ trosoguanidine in een concentratie van $120 \mathrm{mg}$ per liter), terwijl een groep dieren met een BI- of BII-maag normaal drinkwater voorgezet krijgt. Tussen de $29 \mathrm{e}$ en $31 \mathrm{e}$ week na het begin van toediening van de nitrosoguanidine worden de dieren gedood en histologisch onderzocht. Bij 25 van de 66 dieren met een maagoperatie bleek er na toediening van nitrosoguanidine een carcinoom aanwezig. Een carcinoom ontwikkelde zich niet bij de niet geopereerde controlegroep, waaraan nitrosoguanidine werd toegediend en bij de groep met een maagoperatie, die normaal drinkwater voorgezet kreeg. Premaligne afwijkingen (adenomateuze hyperplasie) ontwikkelden zich bij 18 van de 66 geopereerde dieren met nitrosoguanidine, terwijl ook bij één dier van de niet geopereerde controlegroep deze afwijking aanwezig bleek. In de B.I-groep bleek het carcinoom in $80 \%$ van de gevallen aanwezig ter hoogte van het stoma, in $20 \%$ ter hoogte van het corpus van de restmaag. In de BII-groep werden alle carcinomen gezien ter hoogte van het stoma. De auteurs concluderen, dat het stoma van dle geopereerde mag een plaats van voorkeur is voor de ontwikkeling van cen carcinoom; dat, wanneer blootstelling aan carcinogenen plaatsvindt, op deze plaats een carcinoom tot ontwikkeling komt.

Langhans e.a. (1980) verdeelden Wistarratten in zes groepen: BI-maag, BII-maag, BII-maag met Roux-Y-procedure, BlI-maag met Braunse anastomose, gastroenterostomiemaag en een niet geopereerde controlegroep. Het doel van de studie was na te gaan of er tussen de diverse groepen met een wisselende mate van gallige reflux verschillen konden worden geconstateerd ten aanzien van de frequentie van voorkomen van een carcinoom na verloop van tijd. Na 56 weken werden de nog levende dieren gedood (142 van de 265 ratten) en histologisch onderzocht. Er bleken 28 carcinomen aanwezig. Een duidelijke relatie tussen de carcinoomfrequentie en het type var operatie kwam naar voren, met dien verstande, dat bij operatietypen met een in ernst toenemende galreflux, er een toenemend dantal carcinomen werd vastgesteld. De onderzoekers concluderen dat aan de gallige reflux een duidelijke betekenis moet worden toegekend ten aanzien van het ontstaan van carcinomen in de geopereerde maag.

\section{Commentaar}

Ofschoon conclusies uit dierexperimenteel onderzoek zoals beschreven niet zonder meer geldingskracht hebben ten aanzien van de situatie bij de mens, wordt in het algemeen aangenomen, 
dat ook bij de mens de gallige reflux met name in de BIl-maag met retrocolische anastomose een rol speelt in de pathogenese van het stompcarcinoom. Studies die hiervoor het bewijs leveren, zijn in de literatuur niet beschreven.

\subsection{Klinische symptomatologie van het stompcarcinoom}

In de publicaties, waarin aandacht besteed wordt aan het klachtenpatroon van patiënten met een stompcarcinoom (Terjesen e.a. 1976, Wolf e.a. 1977, de Boer e.a. 1978, Tautenhahn e.a. 1979, Rauwerda 1980, Haemers e.a. 1980, Orlandio e.a. 1981, Dougherty e.a. 1982), komt nagenoeg dezelfide combinatie van klachten naar woren: verminderde eetlust, gewichtsverlies, pijn, misselijkhe id en overgeven. De publicaties wisselen ten aanzien van deze symptomen alleen in de volgorde van frequentie van woorkomen.

Kenmerkende afwijkingen bij lichamelijk onderzoek worden niet beschreven, behoudens een palpabele weerstand in de bovenbuik en een vergrote, onregelmatige lever in de ver voortgeschreden gevallen wan een stompcarcinoom met levermetastasen. Biochemisch afwijkende bevindingen in de zin van een ijzergebreksanaemie en obstructieve levertesten worden meestal gezien bij uitgebreide carcinomen met levermetastasen.

\section{Commentaar}

De literatuur vermeldt regelmatig het klachtenpatroon van patiënten met een stompcarcinoom, er vind geen vergelijking plaats met het klachtenpatroon van patienten met een resectiemaag, eenzelfde aantal jaren postoperatief, bij wie bij verder onderzoek geen stompcarcinoom aanwezig blijkt te zijn. Naar alle waarschijnlijkheid zal er sprake zijn van een soortgeljjk klachtenpatroon bij symptomatische patiënten met een resectiemaag vele jaren na de primaire operatie. mogelijk bestatat er een verschil in voorkomen in frequentie van de verschillende klachten, ernst van de vermagering en dergelijke.

\subsection{Diagnostiek van het stompcarcinoom}

Waar in oudere publicaties over het stompcarcinoom nog melding gemaakt wordt van het röntgenonderzoek, blijkt dit nauwelijks het geval in publicaties van recente datum. Door het relatief frequent voorkomen van fout-positieve en fout-negatieve uitslagen, is het röntgenonderzoek als methodiek voor het vaststellen van een stompcarcinoom wrijwel verlaten. De gastroscopie met de moderne flexibele scoop, in combinatie met het nemen van biopsieën voor histologisch onder$20 e k_{,}$is op dit moment het meest betrouwbare onderzoek. De literatuur maakt enerszijds melding van gastroscopisch onderzoek bij de patiënt met klachten, anderzijds van de endoscopie als screening-onderzoek bij het opsporen van het carcinoom in de symptoomloze fase. Geadviseerd word de klachtenvrije patiënt vanaf 10 tot 15 jaar postoperatief regelmatig (om de 1 tot 3 jaar) endoscopisch te onderzoeken om het stompcarcinoom in een curatieve fase te kunnen diagnostiseren. Met nadruk wordt gesteld bij deze patiënten multipele biopsieën met name ter hoogte van het stoma en ook elders in de maag te nemen, aangezien het stompcarcinoom in een vroege fase (intramucosaal carcinoom) endoscopisch niet herkenbaar is.

In het algemeen bevatten de artikelen over de resultaten van endoscopisch onderzoek van de restmaag weinig gegevens over de endoscopische beelden van het stompcarcinoom, met name in de vroege fase hiervan. Krentz (1976) beschrijft in een endoscopische atlas dat een uitgebreid stompcarcinoom zonder probleem te diagnostiseren is. Gewoonlijk worden grove, nodulaire mucosaverdikkingen gezien ter hoogte van de anastomose met soms zwelling en obstructie van de anastomose. De mucosa is in verhoogde mate kwetsbaar. Fibrineuze beslagen, oppervlakkige necrosen en diepe ulcera kunnen het beeld geven van een tumor met proliferatieve en ulcererende groeikenmerken. Maligne veranderingen in een vroege fase kumnen moeilijk te diagnostiseren zi $\mathrm{n}$; biopsieèn kunmen een hulp zijn bij het stellen van de diagnose, evenals gastrofotografie, die in de loop van de tijd met elkaar vergelijkbare beelden geeft. In een monografie over het carcinoom in de geopereerde maag melden Rehner e.a. (1975) onder het hoofdstuk endoscopie, dat grotere ulceratieve laesies en maligne veranderingen in het algemeen endoscopisch gemakkelijk te herkennen zijn, dat de beoordeling van discrete, met name ter hoogte van de anastomose gelocaliseerde geringe afwijkingen veel oefening en ervaring vereist. 
Een enkele auteur (Domellöf e.a. 1976) geeft in een casusbespreking de endoscopische beelden van de individuele patient met een stompcarcinoom. Over bijzondere bevindingen in de restmaag wordt mededeling gedaan, onder andere in een drietal artikelen over poliepen van de resimaag (Janunger e.a. 1978, Stemmermann e.a. 1979, Dirschmid e.a. 1981). Dirschmid wond endoscopisch bij 9 van 1292 patiënten met een geopereerde maag poliepen, waarbij tweemaal spra. ke bleek te zijn van een vroegcarcinoom, eenmaal van een borderline-laesie; zesmaal werd een hyperplastische poliep gezien. Janunger beschrijft bij 30 van 336 endoscopisch-histologisch onderzochte patiënten met een geopereerde maag poliepen. Achtentwintig maal bleek de poliep aanwezig in de directe omgeving van het stoma; histologisch werd 28 maal een hyperplastische poliep gezien, tweemaal een adenomateuze poliep. Bij 3 patiënten met een sessiele, hyperplastische poliep werd in een follow-up studie een stompcarcinoom vastgesteld. Stemmermann beschrijft bij één patiënt met een BI-resectiemaag en bij én patiënt met een BII-resectiemaag hyperplastische poliepen ter hoogte van het stoma, 10 en 11 jaar postoperatief.

Hoewel verondersteld wordt dat een benigne ulcus in de resectiemaag zelden voorkomt meen dan 5 jaar postoperatief, meldt Schmid (1977) in een studie dit fenomeen relatief frequent bij $28 \%$ endoscopisch onderzochte BII-magen, 5 tot 10 jaar postoperatief. Door hem wordt gemeld, dat in de latere postoperatieve fase, het aantal patienten met een benigne peptisch ulcus duidelijk afneemt.

Macroscopisch worden millimetergrote, oppervlakkige witte tot geel-witte mucosa "xantelasmata" door sommige auteurs frequent vermeld (Domellö e.a. 1977: 95 van de 264 patienten met een BII-maag); door anderen in uitzonderlijke gevallen beschreven (Savage e a. 1979:2 van de 673 patiënten met een BI- en BII-resectiemaag; Geboes e.a. 1980: geen van de 56 patiënten met een BII-maag).

Ten aanzien van de "normale" resectiemaag komt uit de literatuar het navolgende beeld naar voren: frequent wordt ter hoogte van het stoma (bij de BII-resectiemaag vaker dan bij de BI-resectiemaag) een rood geinjiceerd slijmvlies gezien, hetgeen ter hoogte van het corpus van de restmaag minder frequent en in minder uitgesproken mate het geval is. De ernst wan een eventueel aanwezige ontsteking kan niet afgelezen worden aan het endoscopisch beeld van het meer of minder geinjiceerde slijmvlies, maar kan slechts histologisch adequaat worden beoordeeld. Een eventuele atrofie van het corpusslijmvlies kan herkend worden aan het zichtbaar zijn van de bloedwaten over een groot deel van het oppervlak van het slijmvlies. Over het percentage van woorkomen van gal in de restmaag en over hoeveelheden gal in de maag in vergelijking met de ernst van de ontsteking werden geen mededelingen in de literatuur gevonden.

\section{Commentaar}

Wanneer in de literatuur geadviseerd wordt de endoscopie als screening-onderzoek te gebruiken voor het opsporen wan het stompcarcinoom in de symptoomloze fase, wordt uitdrukkelijk vermeld multipele biopsieën te nemen, aangezien het carcinoom in een vroege fase endoscopisch vaak niet herkenbaar is. Aangezien op deze wijze geformuleerd er niet van screening sprake kan zijn, aangezien niet voldaan wordt aan een van de belangrijkste voorwaarden woor screening (het beschikbaar zijn van een gevoelige en specifieke methode) dient gesproken te worden ower naonderzoek.

In de literatuur wordt opvallend weinig melding gemaakt van de endoscopische beelden wan patiënten met een vroegcarcinoom in de stomaregio. Weliswar wordt in diverse pulblicatios gewezen op de indeling van deze vroegcarcinomen in de niet geopereerde maag naar criteria, zoals vastgesteld door de Japan Endoscopy Sociëty OCITY (Nagayo 1974), een beschrijwing van de vroegcarcinomen in de stomaregio van de geopereende mag vindt echter miet volgens dezc criteria plaats. Evenmin wordt duidelijk aangegeven, of speciale aandacht moet worden besteed ant bepaalde slijmvliesafwijkingen in de stomaregio zoals ulceratieve laesies, wittige plekken, verhoogde kwetsbaarheid enz.

\subsection{Histologisch onderzoek van stoma- en corpusbiopten van de geopereerde maag}

In enkele studies wordt uitgebreid ingegaan op de bevindingen van histologisch onderzoek van de resectiemaag (Domellö e.a. 1975, 1976, 1977, Schrumpf e.a. 1977, Ewerth e.a. 1978, Savage 
e.a. 1979. Geboes e.a. 1980, Stokkeland e.a. 1981). Door verschillende onderzoekers werden multipele biopten genomen ter hoogte van het stoma en het corpus van de restmaag. In 5 studies worden de gegevens vermeld ower histologische kenmerken van de resectiemaag zoals type slijmvlies, ontsteking, intestinale metaplasie, dysplasie, cystische werwijding van klierbuizen en dergelijke. Schrumpf en Stokkeland (vervolgstudie van Schrumpf) zullen buiten beschouwing worden gelaten, aangezien zij per onderzochte patiënt slechts één histologisch kenmerk vermelden (of ontsteking, of intestinale metaplasie, of dysplasie). Dit wekt verwondering, aangezien per onderzochte patiënt uiteraard steeds combinaties van deze kenmerken vermeld zouden moeten worden.

Domellöf e.a. (1976) vermelden van een groep van 70 patiënten met een BI-resectiemaag, 10 tot 22 jaar postoperatief, als type stomaslijmvlies in $94 \%$ een corpustype, $6 \%$ gemengd corpus-antrumtype. De overige publicaties vermelden hierover geen gegevens. De auteurs vermelden bij $95.7 \%$ van hun patiênten een chronische gastritis ter hoogte wan het stoma, bij $88.3 \%$ ter hoogte van het corpus; een acute gastritis wordt door hen gezien in $80 \%$ ter hoogte van het stoma, in $75.4 \%$ ter hoogte van het corpus. Intestinale metaplasie wordt vermeld bij $40.0 \%$ van de stoma$\mathrm{ta}, \mathrm{bij} 26.1 \%$ van de corpusbiopsieen, terwijl een cysteuze verwijding van klierbuizen in $38.6 \%$ ter hoogte van het stoma, in $26.1 \%$ ter hoogte wan het corpus gezien wordt. Gegevens over het voorkomen van een dysplasie zijn niet aanwezig.

Diomeliöf e.a. (1977) vermelden van een groep van 205 patienten met een BII-resectiemaag, 20 tot 24 jaar postoperatief een chronische gastritis ter hoogte van het stoma in $97.0 \%$, ter hoogte van het corpus in $99.5 \%$ van de gevallen, terwijl een acute gastritis ter hoogte van het stoma in $79.3 \%$, ter hoogte van het corpus in $83.0 \%$ wordt gezien. Atrofie ter hoogte van het stoma wordt vastgesteld bij $68.0 \%$, ter hoogte van het corpus bij $38.8 \%$ van de patiënten. Intestinale metaplasie wordt ter hoogte van het stoma aangetroffen in $33.2 \%$, ter hoogte van het corpus in $27.9 \%$ van de patiënten, terwijl een cysteuze dilatatie van klierbuizen in $69.8 \%$ ter hoogte van het stoma, in 29.1\% ter hoogte van corpus wordt gezien.

Savage e.a. vermelden de gegevens van 63 patiënten (21 BI-, 42 BII-magen) 15 tot 27 jaar postoperatief. Een chronische gastritis ter hoogte van het stoma wordt gezien bij $100 \%$ van de patiënten, ter hoogte van het corpus bij $85 \%$; een acute gastritis blijkt aanwezig in $73 \%$ van de stomabiopsieën, in $60 \%$ van de corpusbiopten. Intestinale metaplasie wordt gezien bij $34 \%$ van de patiënten ter hoogte van het stoma, bij $33 \%$ ter hoogte van het corpus; een cysteuze verwijding van klierbuizen in $55 \%$ van de stomabiopten, in $39 \%$ van de corpusbiopsieën. In deze studie wordt wel aandacht bestered aan het voorkomen van dysplasie: ter hoogte van het stoma wordt in $34 \%$ een lichte, in $19 \%$ een matige dysplasie aangetroffen, terwijl deze percentages ter hoogte van het corpus respectievelijk 44 en 4 zijn.

Geboes e. a. beschrijven de gegevens van 56 BII-resectiemagen, 10 tot 24 jaar postoperatief. De histologische gegevens van stoma- en corpusbiopten zijn niet apart vermeld. Gastritis wordt vastgesteld bij $89.8 \%$ van de patiënten, intestinale metaplasie bij $39.5 \%$. een cysteuze verwijding van klierbuizen bij $55.2 \%$, dysplasie in lichte/matige/ernstige mate bij respectievelijk $21.3 \%$ $7.0 \% / 1.8 \%$ van de biopten. Naar mate het interval na de operatie toeneemt, stijgt het percentage intestinale metaplasie, een matige dysplasie wordt vastgesteld vanaf 15 jaar postoperatief.

Ewerth e.a. melden gegevens van 106 patienten (96 BII-, 15 BI-resectiemagen uit een oorspronkelijke serie van 111 patienten), 22 tot 26 jaar postoperatief. Ter hoogte van het stoma wordt een matig tot ernstig atrofie gezien bij $50.9 \%$ van de patiënten, ter hoogte van het corpus bij $50.9 \%$; een atrofische gastritis wordt vermeld ter hoogte van het stoma in $32.1 \%$, ter hoogte van het corpus in $34.9 \%$. Intestinale metaplasie wordt ter hoogte van het stoma aangetroffen bij $53.8 \%$ van de patiënten, ter hoogte van het corpus bij $39.6 \%$; een matige dysplasie wordt in $5.7 \%$ van de biopten ter hoogte van het stoma, in $1.9 \%$ van de biopsieèn ter hoogte van het corpus gezien.

\section{Commentar}

De gegevens van deze 5 series patiënten overziende zijn zinvolle vergelijkingen nauwelijks mom gelijk, aangezien bij de beoordeling van de histologische gegevens van verschillende criteria werd uitgegaan, niet steeds dezelfde histologische kenmerken werden onderzocht, niet altijd onderscheid werd gemaakt tussen stoma-en corpusbiopsieën.

\subsubsection{Epitheliale dysplasie}

Door Nagayo en Grundmann wordt in 1971 respektievelijk 1975 naar aanleiding van histologisch 
onderzoek van zowel resectiemateriaal als magshijnvliesbiopsieẽn, waarbij de overgang van atypisch epitheel naar carcinoomgroei beschrewen wordt, het begrip dysplasie natar onderscheiden mate van ernst naar voren gebracht. De belangrijkste histologische en cytologische kenmerken van epitheeldysplasie zijn: cellulaire atypie, abnormale differentiatie en desorganisatie van de mucosa-architectuur.

Oehlert e.a. (1975) wijzen erop, dat deze veranderingen van het oppervlakte-epitheel zich zowel bij een foveolaire hyperplasie alsook bij een intestinale metaplasie met of zonder begeleidende chronische of chronisch atrofische gastritis kunnen ontwikkellen. De door hen als dysplasie III beschreven veranderingen komen overeen met het door Mason (1965) beschreven oppervlakki* ge carcinoom van de maag, met de door Schade (1974) als intra-epitheliaal carcinoom gedefinieerde ombouw van oppervlakte-epitheel en zijn in overeenstemming met de door Grundmann beschreven ernstige dysplasie. Vanuit zijn onderzoek wijst Oehlert erop dat mogelijk de als dysplasie II en III beschreven veranderingen van het epitheel in verloop van tijd kunnen teruggan. In een overzichtsartikel in 1980 maken Morson e.a. een onderscheid tussen een precancereuze aandoening, waarvan gesteld wordt dat alleen de atrofische gastritis, pernicieuze anaemie, maagstomp en bepaalde maagpoliepen als zodanig beschouwd kunnen worden, en de precancereuze laesie epitheeldysplasie, gemeenschappelijk bij deze aandoeningen aanwezig, voorkomend zowel in het gewone maagepitheel als bij intestinale metaplasie. De mate van epitheetverandering toont een spectrum van histologische en cytologische afwijkingen, variërend van lichte veranderingen, als resultaat wan ontsteking en regeneratie aanwezig, tot het beeld van ernstige dysplasie, te zien als een overgang naar intramucosaal carcinoom. De mate van uitbreiding van dysplasie over het oppervlak van de maagmucosa kan eveneens als belangrijk worden gek walificeerd. Een ernstige dysplasie is op zich geen indicatie voor een chirurgische interventie, maar maakt zorgvuldige controle wel noodzakelijk. Gewezen wordt op het belang van het nemen van multipele biopten, teneinde deze laesies te kunnen aantonen, respectievelijk niet te missen.

Schrumpf e.a. beschrijven in 1977108 patiënten met een BII-resectie, 20 tot 25 jaar postoperatief, die deels klachtenvrij, deels in verband met klachten endoscopisch worden onderzocht. Twintig biopsieèn worden genomen ter hoogte van het stoma, 20 biopsieèn ter hoogte van het corpus van de maag. Histologisch onderzoek toont één uitgebreid carcinoom (gemengd type), 3 vroegcarcinomen (tweemaal intestinale, eenmaal diffuse type) en 3 patiënten met een ernstige dysplasie (carcinoma in situ). Intestinale metaplasie wordt vastgesteld bij 24 patiënten, een lichte dysplasie bij 52 patiënten, een matige dysplasie bij 12 patiënten. Operatie heeft plaatsgevonden bij 5 patiënten (1 uitgebreid carcinoom, 3 vroegcarcinomen en 1 ernstige dysplasie). Bij 2 patièn" ten bleek het carcinoom multifocaal aanwezig; dysplastische laesies, het gehele spectrum omvattend werden bij alle 5 patiënten gezien.

In een follow-up studie vermelden Stokkeland e.a. in 1981 de resultaten van onderzoek van 58 patiënten. Histologisch werd geen carcinoom of ernstige dysplasie vastgesteld. Van de 31 patiënten met een lichte dysplasie bij voorgaand onderzoek, bleek in 13 gevallen opnieuw een lichte dysplasie aanwezig; van de 9 patiënten met een matige dysplasie bij voorgaand onderzoek werd een lichte dysplasie wastgesteld bij 4 patiënten, een matige dysplasie bij geen van deze patiënten. Van de 18 patiënten zonder dysplasie bij voorgaand onderzoek bleken 2 patiënten nu een lichte, 2 patiënten een matige dysplasie te tonen. Geconcludeerd werd, dat geen progressie van de dysplasie heeft plaatsgevonden. Geadviseerd wordt patiênten met een licht tot matige dysplasie om de 3 tot 5 jaar te heronderzoeken (gastroscopie met multipele biopsieên).

Ewerth e.a. melden in 1978 van 1111 patiënten ( 93 klachtenvrij, 18 met maagklachten), 22 tot 26 jaar na een maagresectie (15 BI-, 96 BII-resectiemagen) de gegevens van endoscopisch en histologisch onderzoek. Multipele biopten werden genomen. Van 106 patienten net goed te beoordelen histollogisch materiaal bleken 25 patiènten een dysplasie te tonen: 19 maal een lichte dysplasic, vijfmaal een matige dysplasie, eenmaal een ernstige dysplasie. Carcinomen werden niet vastgesteld. Conclusies werden door de auteurs niet getrokken.

In 1979 beschreven Savage en Jones 63 patiënten ( 21 met een BI-, 42 met een BII-resectiemaag), 15 tot 27 jaar postoperatief, nauwelijks of geen klachten hebbend. Bij gastroscopie werden multipele biopsieen genomen ( 4 tot 5 ter hoogte van het stoma, 4 tot 5 elders en bovendien eventueel vanuit slijmvlieslaesies). Histologisch werd een lichte dysplasie vastgesteld bij 22 patiënten ( $34 \%)$ ter hoogte van het stoma, bij 28 patiënten $(44 \%)$ ter hoogte van het corpus, een matige dysplasie bij 12 patiënten (19\%) ter hoogte van het stoma, bij 3 patiënten ( $4 \%$ ) ter hoogte van het corpus. Dertien van de 14 patiënten met een matige dysplasie werden opnieuw onderzocht. Histologisch onderzoek toonde een matige dysplasie bij 11 patiënten ter hoogte van het stoma, bij 9 patiënten ter hoogte van het corpus, terwijl eenmaal een ernstige dysplasie gezien werd ter hoogte van het stoma. Operatie vond plaats bij de patiënt met de ernstige dysplasie, een carci- 
noom werd histologisch niet gevonden. Door de auteurs wordt intestinale metaplasie (door sommigen als precancereus gezien) op zich zelf niet een voldoende indicatie geacht voor radicale matregelen. Iichte dysplasie wordt door hen als een reactieve verandering gezien, waarbij verdere controle niet noodzakelijk is. Matige of ernstige dysplasie wordt als premaligne beschouwd (mate varn risico onbekend). Patiënten met een matige dysplasie worden zorgvuldig vervolgd. Geboes e.a. beschrijuen in 1980 een serie wan 56 patienten met een BII-resectiemaag, 10 tot 24 jar postoperatief, in verband met klachten geêndoscopieerd. Multipele biopsiën worden genomen ter hoogte van stoma en corpus. Een carcinoom wordt bij 5 patiënten ( $8.9 \%$ ) wastgesteld. Histollogisch onderzoek toont vijfmaal een carcinoom wan het diffuse type. Een lichte dysplasie blijkt bij 17 patiënten $(30.0 \%)$, cen ernstige dysplasie bij 1 patiënt (1.8\%) aanwezig te zijn. Geadwiseerd wordt patiënten met een intestinale metaplasie (beschouwd als een precancereuze conditie) nauwkeurig te vervolgen. Eenzelfde advies wordt gegeven ten aanzien wan patienten met een lichte dysplasie (waarvan de betekenis niet duidelijk geacht word": resultaat van regeneratieve fenomenen of neoplastische veranderingen?) en matige dysplasie (beschouwd als een maligne laesie). Patiënten met een ernstige dysplasie dienen eventueel te worden geopereerd.

Offerthaus e.a. vermelden in cen korte beschouwing in 1982 de resultaten van een bioptisch- endoscopisch onderzoek van 504 patiënten, die meer dan 15 jaar tevoren een partiële maagresectie hebben ondergatn. Bij eerste onderzoek werden 8 maagstompcarcinomen ( 3 vroegcarcinomen) gevonden (4 endoscopisch waargenomen), 5 patiënten toonden een dysplasie graad III. Na-onderzoek van deze 5 patiènten leverde bij 2 een endoscopisch niet waargenomen vroegcarcinoom op. Bij de overige 3 patiënten werd geen progressie of regressie van de afwijking vastgesteld. Vijfenzestig patienten hadden bij eerste onderzoek een lichtere graad van dysplasie, bij 21 patiënten volgde na-onderzoek, waarbij negenmaal lichte tot matige dysplasie aanwezig bleek, de overigen toonden geen dysplasie. Honderdeenenveertig patienten, die bij eerste onderzoek geen dysplasie hadden, werden voor controle gezien: bij 22 patienten werd nu een lichte tot matige dysplasie vastgesteld, bij 1 patiënt een ernstige dysplasie. Gestelld wordt, dat voor een tijdige ontdekking van een maagstompcarcinoom en opsporing van premaligne slijmvliesafwijkingen uitvoerig biopteren noodzakelijk is. Reversibiliteit van ernstige dysplasie lijkt onwaarschijnlijk, het klinisch belang van lichtere graden van dysplasie is minder duidelijk.

\section{Commentaat}

Bij de beschouwingen over de dysplasie als een eventuele premalige slijmwliesafwijking, komt duidelijk maar voren dat dysplasie in geringe mate slechts gezien mag worden als passend bij ontsteking of regeneratie van het slijmvlies in de restmaag. De betekenis van dysplasie van matige ernst is niet duidelijk; gegevens uit de literatuur geven te weinig steun aan de opvatting, dat dysplasie wan matige ernst gezien client te worden als een premaligne afwijking van het slijmvlies. Terwijl sommige auteurs bij controle-onderzoek van patiënten met een matige dysplasie dit fenomeen opnieuw vaststellen in een hoog percentage van de onderzoeken, blijkt zulks bij andere onderzockers niet het geval te zijn. De als ernstige dysplasie gekwalificeerde slijmvliesafwijkingen van de restmaag worden door vrijwel alle auteurs gezien als een carcinoma in situ.

\subsection{Therapie van het stompcarcinoom}

In de literatuur wordt in diverse studies angegeven, dat de chirurgische therapie van het stompcarcinoom gepaard gaat met veel postoperatieve complicaties en dat de prognose slecht is.

Radomsky e.a. (1978) vergeleken de resultaten wan operatie van 40 patiënten met een stompcarcinoom mot die van 112 patiënten met een totale gastrectomie uit een serie van 11.52 patiënten met een primair maagcarcinoom. "Zeventien patiënten met een stompcarcinoom bleken inoperabel te zijn, 14 mal werd een totale gastrectomie verricht, achtmaal een subtotale maagresectie bij een kllein tot het stoma beperkt carcinoom, eenmaal werd een endoprothese aangebracht. In de groep van 14 maagstompcarcinoompatiënten met een totale resectie werden frequenter complicaties gezien in de zin van een gestoorde wondgenezing, naadinsufficiëntie en cardiopulmonale problemen dan in de groep van 112 patiënten met een gewoon magcarcinoom, die een totale maagresectie ondergingen. Zes van de 14 patiënten ( $43 \%$ ) overleden postoperatief, in vergelijking met 17 van de 112 patiënten $(15 \%$ ) uit de groep totale gastrectomieèn bij de primaire maagcarcinoompatiënten. Complicaties en mortaliteit bleken significant minder aanwezig in de groep stompcarcinoompatiënten met een subtotale maagresectie. 
Andere auteurs (Kootz 1966, Kronberger e. a. 1968. Bötrcher e.a. 1973, Dahm a.a. 1975) melden eveneens een hoge postoperatieve mortaliteit (22 tot $60 \%$ ) na totale magresectie bij patuenten met een stompcarcinoom. Als oorzaken worden genoemd het late tijdstip van de diagnose, de slechte algemene conditie (cachexie, hypoprotemaemie) op het moment van de operatie. Ook de prognose op langere termijn biedt weinig gunstige perspektieven woor de stompcarcinoompatienten. Radomsky e.a. (1978) melden in hun studie, dat 2 jaar na de operatie nog slechts 2 van de 40 patiënten in leven zijn. Peitsch e.a. (1979) gingen de lotgevallen van 55 patienten met cen stompcarcinoom na: slechts 8 van de 55 patiënten konden radikaal worden geopereerd (subtotale of totale gastrectomie), 9 patienten ondergingen een palliatieve resectie, bij alle overige pa* tiënten bleek het carcinoom inoperabel te zijn. Postoperatief overleed $21.8 \%$ van de patiënten, 12 maanden na operatie was slechts $14 \%$, na 2 jaar $9 \%$ van de patiënten nog in leven. Slechts 1 patiènt overleefde 5 jaar.

De gegevens van de Boer e.a. (1978) worden vermeld in Tabel 2.6.

Terjesen e.a. (1976), Wolf e.a. (1977), Rauwerda e.a. (1979), Tautenhahne.a. (1979), Haemers e.a. (1980), Hünicke e.a. (1980), Langhans e.a. (1980) en Orlando e.a. (1981) bevestigen de slechte prognose van patiènten met een stompcarcinoom. Vrijwel alle genoemde auteurs besluiten hun artikel met een soortgelijke conclusie als de Boer e.a. (1978): voorkomen van het inoperabel zijn wan het stompcarcinoom is misschien mogelijk, wanneer iedere asymptomatische patiënt, die een maagresectie heeft ondergaan, endoscopisch gescreend wordt vanaf 15 jaar na de primaire operatie en wanneer alle patiënten met klachten, ontstaan na een geheel of vrijwel geheel symptoomvrije periode als verdacht voor een stompcarcinoom worden beschouwd.

Tabel 2.6. Verschillende vormen van behandeling met corresponderende overlevingsdutr van patienten met een stompcarcinoom (de Boer 1978)

\begin{tabular}{|c|c|c|c|c|c|c|}
\hline \multirow{2}{*}{$\begin{array}{l}\text { behandelings } \\
\text { rormen }\end{array}$} & \multirow{2}{*}{$\begin{array}{l}\text { auntal } \\
\text { patië̀y- } \\
\text { ten }\end{array}$} & \multirow{2}{*}{$\begin{array}{l}\text { overle- } \\
\text { ving in } \\
\text { maanden }\end{array}$} & \multicolumn{2}{|c|}{ overledenpat. } & \multicolumn{2}{|c|}{ inlevenzinde pat } \\
\hline & & & asnots & $\begin{array}{l}\text { overle. } \\
\text { vingsitijd } \\
\text { (mond) }\end{array}$ & aantal & $\begin{array}{l}\text { overle } \\
\text { vingstijd } \\
\text { (mnd) }\end{array}$ \\
\hline \multicolumn{7}{|l|}{ totale } \\
\hline gastrectomie & 26 & 14.1 & 19 & 12.4 & 7 & 16.8 \\
\hline reresectie & 16 & 11.7 & 11 & 4.2 & 5 & 26.8 \\
\hline bypass procedure & 10 & 48 & 10 & 4.8 & (l) & \\
\hline \multicolumn{7}{|l|}{ exploratieve } \\
\hline laparotomie & 15 & 5.1 & 15 & 5.1 & 0 & \\
\hline geen laparotomie & 19 & 3.9 & 16 & 3.8 & 3 & 4.3 \\
\hline curatieve resectic & 24 & 16.4 & 14 & 11.1 & 10 & 24.2 \\
\hline
\end{tabular}

\section{Commentaar}

Als reactie op het artikel wan Radomsky over de hoge mortaliteit en het grote actutal postoperaltieve complicaties van maagstompcarcinoompatiënten na cen totale resectic, kan gesteld worden, dat in verband met de vermelde cachexie, hypoproteïnaemie e.d. een goede voorbereiding op de operatie via totaal parenterale voeding geindiceerd zou zijn geweest. In dat geval zouden mogelijkerwijs het aantal postoperatieve complicaties en de mortaliteit minder zijn geweest. Overigens komt de vraag naar voren of operatieve therapie van de patienten met een maagstompcarcinoom betere resultaten oplevert dan de conserwatief internistische benadering. Die gegewens wan de Boer e.a. doen vermoeden dat conservatief internistische therapie de slechtste prognose heeft. Individuele ziektegeschiedenissen ontbreken echter, zodat de verschillende vormen van therapie niet goed vergelijk baar zijn tegen de achtergrond wan klinische gegevens zoals de algemene conditie van de patient, de uitgebreidheid van het maagstompcarcinoom, het voorkomen van eventuele metastasen enz.

Bij mededelingen, dat door chirurgische therapie in de wroege fase van het stompcarcinoom veel betere resultaten kunnen worden behaald dan wanneer operatie plaatsvindt bij de symptomatische patiënt met een uitgebreid stompcarcinoom, dienen enkele kanttekeningen te worden gemaakt.

Metingen van de groei van een maligne maagproces hebben aangetoond, dat de verdubbelingstijd yan de laesie in de vroege fase erg lang is (555-3076 dagen), vergeleken met die van metasta- 
sen (17-90 dagen). De groei wan het maagcarcinoom is 30 maal sneller in de late dan in de vroege fase (Fujita 1978, Kawai e.a. 1974). De progressie van het carcinoom kan in de praemaligne fase in dekaden, in de yroege fase in jaren, in de eindfase in maanden gemeten worden. Hieruit is te concluderen, dat patienten met een stompcarcinoom in de vroege fase ook zonder operatie waarschijulijk in een aantal gevallyen nog jarenlang asympt omatisch kunnen blijven. De prognose, gemeten naar de vijf-jaars overlevingsduur, is veel gunstiger bij operatie van patiënten met een maagcarcinoom in de vroege fase (95\% vijf-jaars overleving bij een carcinoom beperkt tot de mucosa; $87 \%$ bij een carcinoom beperkt tot mucosa en submucosa), dan wanneer het carcinoom geopereerd wordt in een latere fase ( $24 \%$ wijf-jaars overleving bij uitbreiding to in de serosa; $9 \%$ bij uitbreiding buiten de maag) (Kidokoro e. a. 1980). Derhalve likt de prognose van een patiënt met een carcinoom in de wroege fase op korte termijn goed, op lange termijn slecht te zijn. Bij een patient met eefu verhoogd risico voor operatie dient bij de beslissing opereren ja/nee met deze overweging rekening te worden gehouden. Een complicerende factor hierbij vormt het feit, dat slechts histologisch onderzoek wan het operatiepreparaat definitief leert, of er inderdaad sprake is van een vroegcarcinoom.

\section{Hoofdstuk 3}

\section{Vraagstelling van het onderzoek}

Zoals aangegeven in de inleidling werd op grond van eigen ervaring met patiënten met een geopereerde maag en op basis van de bestudeerde literatuur besloten de navolgende zaken verder te onderzoeken:

- 1: de frequentie van voorkomen van het stompcarcinoom in de BI- en BII-resectie maag;

2: endoscopische en histologische beelden bij patiënten met een BI- en BII-resectiemaag, meer dan 10 jaar postoperatief, waarbij een onderscheid gemaakt wordt tussen patiënten met en zonder klachten;

3: endoscopische en histologische beelden van patiënten met een stompcarcinoom van de BIen BII-resectiemaag, waarbij een onderscheid gemaakt wordt tussen patiënten met en zonder klachten;

4: de prognose van patiënten met een stompcarcinoom van de resectiemaag "waarbij vergeleken wordt de groep patiënten met en zonder klachten;

5: de eventuele aanwezigheid en betekenis in premaligne zin van endoscopusch en histologisch vast te stellen slijmvliesafwijkingen in de stomaregio;

6: een eventueel volgens bepaalde criteria uit de populatie BI-BIImaagpatiënten te selecteren groep, in aanmerking komend woor onderzoek op een beginnend stompcarcinoom.

De haalbaarheid van dit onderzoek met genoemde vraagstelling werd bekeken in 1980 en als volgt beoordeald.

Om een indruk te kunnen krijgen van de frequentie van voorkomen van het carcinoom van de geopereerde maag in Maastricht en ongeving en tevens gegevens in handen te krijgen over relaties van het stompcarcinoom met geslacht/leeftijd van patiënten, tijdsinterval primaire operatie-diagnosestelling stompcarcinoom en dergelijke, bleek het noodzakelijk over de volgende gegevens te kunnen beschikken:

- het in het verleden verrichte aantal maagoperaties, onderwerdeeld in BI-, BII- en GE-maag, met bijbehorende data zoals naam, geslacht, geboortedatum van patiënt, jaar van operatie; - de verdere lotgevallen van deze patiënten, waarvan onder andere bekend dienen te zijn de cventuele data en oorzaken van overijden;

- endoscopische en histologische gegevens van nog levende patiënten ter vaststelling van een eventueel op dat moment aanwezig stompcarcinoom.

Bij navraga bleken slechts de operatieboeken vanaf het jaar 1952 ter beschikking te staan, gegevens uit de jaren voorafgaande aan 1952 bleken vernietigd bij de overgang van het oude naar het huidige ziekenhuis. De operatieboeken bevatten de navolgende gegevens: jaartal en datum van operatie, naam patiënt en afdeling van herkomst in het ziekenhuis, aard van de operatie, naam van chirurg en narcotiseur.

De geboortedata van de patiënten bleken niet vermeld te zijn. Onder het hoofd aard van de ope- 
ratie werden ten aanzien van aan maag-duodenum gerelateerde problemen de navolgende aanduidingen gegeven: maagresectie, BI-maag, BII-maag, GE-maag, maagoperatie, maagperforatie, overhechting, maagloloeding, ulcus duodeni, ulcus ventriculi, maagcarcinoom, maag. In de periode 1952 tot 1964 werd alleen gesproken wan maagresectie zonder verdere onderverdeling in BI-, BII- en GE-maag, de periode 1964 tot en met 1971 gaf in een aantal gevallen een onderverdeling van maagresecties in BI- en BII-maag te zien. Wanneer er vanuit gegaan wordt, dat de diverse aanduidingen, behalve overhechting an GE-maag, aangeven dat een resectie verricht werd, kan uit de gegevens het aantal maagresecties per jaar worden berekend. Hierbij kan worden opgemerkt, dat geen zekerheid bestaat over het verricht zijn van een resectie bij aanduidingen zoals maagoperatie, maagperforatie, maagbloeding, ulcus duodeni, ulcus ventriculi, maag. carcinoom en maag. Evenmin kan in een groot aantal gevallen onderscheid gemaakt worden naar BI- en BII-resecties. Het ontbreken van geboortedata maakt het opzoeken van de statussen, waaruit de gewenste gegevens naar alle waarschijnlijkheid gehaald kunnen worden uitermate gecompliceerd. Bij pogingen hiertoe blijken bovendien veel statussen niet vindbaar, bij nawraag blijkt dat in de onderzochte periode sommige chirurgen de gewoonte hadden de patiëntenstatussen thuis te bewaren.

Wanneer bovendien in aanmerking genomen wordt het feit dat veel patiënten inmiddels overleden zijn, terwijl vaak geen obductie verricht werd, de literatuur erop wijst dat veel nog in leven zijnde patiënten een endoscopie in het kader van een screening weigeren te ondergaan, het lot wan de nog levende, niet-carcinoompatiënten uiteraard voor de komende decennia niet bekend is (patiënten bekend via operatieboeken vanaf 1952, gemiddeld interval primaire operatie-diagnosestelling stompcarcinoom meer dan 20 jaar!), kan met aan zekerheid grenzende waarschijnlijkheid gesteld worden, dat het op dit moment niet mogelijk zal zijn uit ter beschikking staande gegevens een betrouwbare frequentie van voorkomen van het stompcarcinoom van de geopereerde maag in Maastricht en omgeving te berekenen.

Vraagstelling 1 bleek derhalve niet te beantwoorden.

Bij analyse van de in 1980 beschikbare patiëntengegevens in verband met de vraagstellingen 2 tot en met 6 , komen de volgende gegevens naar voren:

- de overgrote meerderheild van de geëndoscopieerde patiënten met cen BI- en BII-maag werd onderzocht in verband met klachten. Een begin werd gemaakt met het onderzoek van symptoomloze patiënten met een BII-maag meer dan 10 jaar postoperatief, onder andere via met de huisartsen gemaakte werkafspraken via het Diagnostisch Centrum;

van alle geëndoscopieerde patiënten bleken duidelijk anamnestische gegevens aanwezig zoals jaartal van primaire operatie, klachtenpatroon e.d.;

vrijwel alle endoscopieën werden door dezelfde onderzoeker (auteur van dit proefschrift) verricht; nauwkeurige verslaglegging beeft plaatsgevonden;

bij vrijwel alle patiënten werd tijdens de endoscopie materiaal verzameld voor histologisch onderzoek, waarbij dient te worden aangetekend dat in de periode 1972 tot 1980 dit materiaal meestal beperkt bleef tot én biopsie ter hoogte van het stoma en én biopsie ter hoogte van het corpus, terwijl vanaf 1980 ter hoogte van het stoma en corpus van de maag telkens tenminste vier biopsieën werden genomen;

in de periode 1972-1980 werd het histologisch onderzoek van de biopsieën door verschillende patholoog-anatomen verricht; vanaf 1980 door dezelfde patholoog-anatoom (J.W.A.), die ook de biopsieën uit de periode 1972-1980 herbeoordeelde;

bij 39 patienten, in het verleden geopereerd in verband met een goedaardige aandoening, werd een stompcarcinoom endoscopisch en histollogisch gediagnostiseerd; het fenomeen dysplasic werd bij histologisch onderzoek van biopten in ongeveer $25 \%$ van het onderzochte materiaal vastgesteld.

Gezien de vraagstellingen van het onderzoek leek het noodzakelijk:

- de groep symptoomloze patiënten, endoscopisch te onderzoeken op een stompcarcinoom uit te breiden;

- per endoscopisch onderzoek tenminste 4 biopsieën te nemen van stoma en corpus van de małg, om de kans zo groot mogelijk te maken eventueel premaligne of maligne afwijkingen op histologisch niveau te ontdekken;

- een revisie van tot dusver via endoscopie verkregen histologisch materiaal te laten verrichten volgens vast te stellen criteria door éen patholoog-anatoom.

Wanneer aan deze voorwaarden zou kunnen worden woldaan, leek een onderzoek naar de wraagstellingen 2 tot en met 6 haalbaar. 
Besloten werd volgens bovensitande lijnen het onderzoek voort te zetten. De volgende vraagstellingen komen dan naar voren:

- 1 bestaan er tussen patiènten met een BI- en BII-resectiemaag, meer dan 10 jaar postoperatief, onderscheiden naar het al of niet aanwezig zijn wan klachten, verschillen ten aanzien wan:

- endoscopische en histologische beelden;

- de frequentie van woorkomen van een stompcarcinoom;

- de prognose van het eventueel gediagnostiseerde stompcarcinoom;

- 2 heeft het histologisch fenomeen matige dysplasie enige betekenis als premalligne kenmerk wan een stompcarcinoom:

- 3 kan er op grond van te omschrijven criteria uit de grote groep BI- en BII-resectiemagen een subgroep patienten geselecteerd worden, bij wie onderzoek op het woorkomen van een stompcarcinoom zinvol is met het oog op een curatieve behandeling.

\section{Hoofdstuk 4}

\section{Patiënten en methoden}

\subsection{Patiëntengroepen}

Voor deze studie zijn de patiënten in de volgende groepen onderverdeeld:

- groep 1: 174 patiënten met een BII-resectiemaag, meer dan 10 jaar postoperatief, in verband met klachten onderzocht in de periode 1970 tot en met 1979 ;

- groep 2: 118 patiënten met een BII-resectiemaag, meer dan 10 jaar postoperatief, in verband met klachten onderzocht in de periode 1980 tot en met 1982;

- groep 3: 1.38 patiënten met een BII-resectiemaag, meer dan 10 jaar postoperatief, klachtenvrij, onderzocht op het voorkomen van een stompcarcinoom in de periode 1980 tot en met 1982;

groep 4: 58 patiënten met een BI-resectiemaag, meer dan 10 jaar postoperatief, in verband met klachten onderzocht in de periode 1970 tot en met 1979;

- groep 5: 49 patiënten met een BI-resectiemaag, meer dan 10 jaar postoperatief, in verband met klachtem onderzocht in de periode 1980 tot en met 1982;

- groep 6: 43 patiënten met een BI-resectiemaag, meer dan 10 jaar postoperatief, klachtenvrij, onderzocht op het voorkomen van een stompcarcinoom in de periode 1980 tot en met 1982;

- groep 7: 51 patiënten met cen BII-resectiemaag, minder of meer dan 10 jaar postoperatief, in verband met een bloeding onderzocht in de periode 1970 tot en met 1982

De patienten, endoscopisch en histologisch onderzocht in de periode 1970 tot en met 1979, waren vrijwel zonder uitzondering afkomstig uit de polikliniek en kliniek van de Afdelingen lnterne Geneeskunde en Heelkunde.

De patiènten, onderzocht in de periode 1980 tot en met 1982, waren enerzijds afkomstig uit de polikliniek en kliniek van de. Afdelingen Interne Geneeskunde en Heelkunde, anderzijds waren zij rechtstreeks door de huisarts verwezen naar de Afdeling Endoscopie. In deze periode werd via het Diagnostisch Centrum aan de huisarts de mogelijkheid geboden op indicatie endoscopisch onderzoek van patiënten te doen plaatsvinden. In een brief aan de huisarts werd met name de nadruk gelegd op het endoscopisch onderzoek van de BII-resectiemaag-patiënten met klachten en van symptoomloze patiënten met een BII-resectiemaag meer dan 10 jaar postoperatief, ter vaststelling van een maagstompcarcinoom in een curatieve fase.

\subsection{Onderzoekgegevens}

Van alle patiënten werden de gegevens verzameld van anamnese, endoscopisch en histologisch onderzoek; van de patiënten met een stompcarcinoom werd de gehele ziektegeschiedenis bekeken. 
Op enkele uitzonderingen na werden alle bij het onderzoek betrokken patiënten bekeken door eén onderzoeker (auteur van deze studie).

Het histologisch onderzoek van alle patienten werd door tén patholoog-anatoom (J.W.A.) beoordeeld, eventueel herzien.

\subsubsection{Gegevens van de anamnese}

Een standaard anamnese werd steeds opgenomen, voorafgaande aan het endoscopisch onderzoek. Gegevens werden gecontroleerd via bestudering wan het klinisch en poliklinisch archief. Van een aantal patiënten bleek het niet mogelijk te beschikken over gegevens uit de klinische status ten tijde van de primaire operatie, aangezien deze status niet altijd vindbaar blek te zijn. Wanneer patiënten in onzekerheid verkeerden over gegevens uit de ziektegeschiedenis zoals tijdstip primaire operatie, indicatie primaire operatie en dergelijke, werd getracht deze gegevens te verkrijgen via huisarts, eventueel via familieleden van de patiënt.

De volgende gegevens werden verzameld: leeftijd, geslacht, tijdstip primaire operatie, aard primaire operatie, indicatie primaire operatie, tijdsinterval tussen primaire operatie en endoscopisch onderzoek; klachtenpatroon, bestaande uit de symptomen verminderde eetlust, vermagering, opboeren, zuurbrandlen, misselijkheid, overgeven, pijn.

\subsubsection{Gegevens van de endoscopie}

Het endoscopisch onderzoek werd vrijwel steeds verricht in de morgenuren tussen 7.00 en 8.30 uur, waarbij de patiënt nuchter was vanaf 22.00 uur de avond voorafgaand aan het onderzoek. In voorbereiding op het onderzoek werd de keel gesprayd met lidocaïne $10 \%$. Andere medicatie werd niet gegeven, de maag werd niet geheveld voor onderzoek. Zonodig werd tijdens onderzoek via de endoscoop antifoam in de maag gespoten.

Onderzoek werd steeds verricht met endoscopen met voorwaartsgerichte optiek.

Van het endoscopisch onderzoek werden de volgende gegevens verzameld:

- beoordeling van het stoma, waarbij onderscheid gemaakt werd tussen een wijd openstaand stoma, gekwalificeerd als een normaal stoma; een stoma dat zich presenteert als een plooiconvergentie, via luchtinsufflatie goed te ontplooien is, gemakkelijk te passeren met de endoscoop; een stenotisch stoma niet te ontplooien via luchtinsufflatie, niet te passeren met de endoscoop;

- beoordeling van het stoma op ontsteking. Een onderscheid wordt gemaakt tussen geen ontsteking, wanneer het stomaslijmvlies niet geinjiceerd is; cen matige of duidelije ontsteking, al naar gelang het slijmwlies minder of meer rood geinjiceerd is;

- beoordeling van het stoma op andere kenmerken; gelet werd op het al dan niet glad begrensd zijn van het stoma, de anwezigheid van forse plooien, nodulariteiten van de rand, slimvliesonregelmatigheden, star/spekkig zijn van het slijmvlies (o.a. gekenmerkt door niet meegegeven van het weefsel via palpatie met de gesloten biopsietang), kleur van het slimvilies (met name wittige plekken door overgrijpen van jejunumslijumlies op de stomarand, de aanwexigheid van xantelasmata, de aanwezigheid van intestinale metaplasie op histologisch niweau), cen toegenomen kwetsbaarheid van het slijmvlies (verhoogde bloedingsneiging bij manipuleren met de endoscoop, nabloeden bij biopteren), de aanwezigheid van ulceratieve laesies, polipoide afwijkingen, matigne aandoend weefsel;

- de beoordeling van het corpus op ontsteking: de mate van gastritis werd op dezelfde wijze becordeeld als ter hoogte van het stoma; gelet werd op atrofie van het slijmvlies (doorschemeren van bloedvaten door de mucosa, zonder voorafgande luchtinsufflatie, eventueel na het laten ontsnappen van de lucht via de endoscoop);

- beoordeling wan het corpus op andere kenmerken: gelet werd op dezelfde fenomenen zoals beschreven bij de beoordeling van het stoma; tevens werd andacht besteed aan de eventuele aanwezigheid van retentiemateriaal;

- beoordeling op hoeveetheid gal, direct na introductie van de endoscoop in de maag. Onderscheid werd gemaakt tussen geen gal, matig veel gal wanneer enige coating van het slijmvlies met galvokjes en enige galbijmenging van het maagsecreet had plaatsgevonden; veel gal, wanneer er sprake was van galmeertjes ter hoogte van de restmaag. 


\subsubsection{Gegevens van histologisch onderzoek}

Voor histologisch onderzoek werden in de periode 1970 tot en met 1979 bij vrijwel alle patienten biopsieèn genomen, meestal ến biopsic ter hoogte van het stoma en ến ter hoogte van het corpus van de restmaag. In de periode 1980 tot en met 1982 werdien tenminste vier bjopsieen genomen ter hoogte van het stoma en vier biopsieën ter hoogte van het corpus van de restmaag (kleine curvatuurzijde-achterwandzijde-grote curvatuurzijde-voorwandzijde). Bij afwijkende slijmvliesbevindingen, met name bij enige verdenking op maligniteit, werden meer biopsieën ter plaatse genomen. Poliepen werden, indien aanwezig, via de diathermiesnatar verwijderd.

De tijdens endoscopie voor het histologisch onderzoek genomen biopten werden niet ieder afzonderlijk in een potje formaline gedaan. Wanneer behoudens een gastritis bij endoscopisch onderzoek overigens geen afwijkingen naar voren kwamen, werden de stomabiopsieën in één potje, de corpusbiopsieën in een ander potje bewaard. Bij afwijkend endoscopische bevindingen, werden de uit deze slijmvliesgebieden afkomstige biopsieën elk in een apart potje gedaan. Weefselmaterial werd gefixeerd in $10 \%$ neutraal gebufferde formaline en ingebed in paraplast. Van ieder blokje werden op drie niveaus 5 micronplakjes gesneden en gekleurd met haematoxylineeosine.

Histologisch werden coupes beoordeeld op de volgende gegevens:

-stoma: slijmvlieskarakter (antrum-, corpus-, antrum-corpustype);

ontsteking (geen, focalal, diffuus);

ontsteking (geen, licht, matig, ernstig);

cysteuze verwijding van klierbuizen;

intestinale metaplasie;

dysplasie (licht, matig);

carcinoom (diffuus-intestinaal type);

poliepen (adenomateus en hyperplastische type).

-corpus: ontsteking (geen, focaal, diffuus);

ontsteking (geen, licht, matig, ernstig);

cysteuze verwijding van klierbuizen;

intestinale metaplasie;

dysplasie (licht, matig);

aantal zoutzuurcellen (voldoende, verminderd, afwezig);

carcinoom (diffuus of intestinaal type).

\section{Omschrijving van de histologie:}

Histologische beoordeling van het fenomeen gastritis vond plaats volgens de criteria van Whitehead (1973), de dysplasie werd bekeken volgens criteria uit het werk van Nagayo (1971), de onderverdeling van carcinoomtypen vond plaats volgens Lauren (1965).

\section{De normale corpusmucosa:}

Het oppervlakte-epitheel bestaat uit een enkele laag cylindrische cellen met een basaal gelegen kern. Het oppervlakte-epitheel verdwijnt op vele plaatsen in de diepte, vormt zo ondiepe maagputjes (foveolae), waarin ongeveer 4 dieper gelegen klierbuisjes uitmonden. Dit zijn eenvoudige rechte buisjes die dicht op elkaar liggen en van ongeveer gelijke lengte zijn. Zij nemen $3 / 4$ van de mucosadikte in. Het grootste deel van de cellen, die het bovenste gedeelte van de klierbuizen bekleden, bestaat uit pariëtale cellen. Ter hoogte van de uitmonding van de klieren in de putjes bevinden zich de slijmsecernerende nekcellen. Het onderste deel van de klierbuizen bevat de hoofdcellen. Ter hoogte van de basis bevinden zich af en toe argentaffine cellen.

\section{De normale antrummucosa:}

De maagputjes zijn hier dieper en soms vertakt; de klierbuizen korter en liggen minder dicht op elkaar gepakt dan in het corpus. Zij eindigen op verschillende niveaus en nemen ongeveer de helft of minder van de mucosadikte in. De tubuli verlopen gekronkeld, enkelvoudig of vertakt. Zij zijn bekleed met slijmsecernerende cellen en een enkele pariëtale cel. Argentaffine cellen komen meer frequent voor dan in andere delen van het maagslijmvlies. 
Chronische gastritis (licht-matig-emstig):

Het oppervlakte-epitheel kan degeneratieve of regeneratieve veranderingen wertonen, De cellen kunnen afgeplat of kubisch zijn met hyperchromatische kernen, terwijl er een gedeeltelijk of total verlies van de slijmkolom opgetreden is. De basophilie van het cy toplasma is toegenomen. De epitheelcellen kunnen een meerrijige laag wormen. Als degeneratieve weranderingen overheersen kunnen polymorfnucleaire leucocyten en af en toe ook lymfocyten het epitheel bimnen. dringen. Deze epitheelveranderingen kunnen eveneens aangetroffen worden in de foveolae. Een invasie van het klierbuisepitheel door pollymorfnucleaire leucocyten kan voorkomen, waarbij deze cellen zich soms ophopen in het verwijde lumen.

De klierbuizen kunnen nomaal blijven ondanks ernstige veranderingen ter hoogte van het oppervlakte-epitheel en de maagputjes.

In de lamina propria kan zich een ontstekingsinfiltraat bevinden van plasmacellen, lymfocyten, eosinophiele en neutrophiele polymorfnucleaire leucocyten. Het infiltraat blijtt meestal beperkt tot het gebied tussen de foveolae.

De ernst van de epitheelveranderingen, uitgebreidheid en dichtheid van het cellulaire infiltraat bepalen de graad van de ontsteking: licht, matig of ernstig.

Atrofrsche gastritis:

Wanneer de bovenomschreven veranderingen eveneens ter hoogte van de klierlaag aanwezig zijn en atrofie van tubuli kan worden vastgesteld, wordt er gesproken van een atrofische gastritis.

\section{Cysteuze verwijding van klierbuizen:}

Wanneer een klierbuis een 2 of meer dan tweemaal zo wijd lumen bezit als normaal, wordt gesproken van een cysteuze verwijding.

\section{Intestinale metaplasic:}

Kenmerkende verschijnselen van intestinale metaplasie zijn de aanwezigheid wan Goblet-cellen en cellen van Paneth in het maagslijmvlies.

\section{Dysplasie:}

Lichte dysplasie: de epitheelcellen, die een tubulus bekleden zijn hoog en hyperchromatisch met geëlongeerde, opvallende kernen. De kern-cytoplasma-ratio is toegenomen; de kernen zijn nog* al gelijkvormig en basaal gericht. Lichte irregulariteit van klierbuizen is aanwezig.

Matige dysplasie: de kernen zijn afgerond en blazig en geëlongeerd; de kern-cytoplasma-ratio is verder toegenomen; sommige kernen reiken tot aan de lumengrens van de cel. Er kan sprake zijn van enig pleiomorfisme, lichte architecturale afwijkingen van tubuli komen woor.

Ernstige dysplasie: de tekenen van een matige dysplasie zijn meer frequent en uitgesproken aanwezig, er is meer pleiomorfisme en vooral een toename van de architecturale afwijkingen valt op.

\section{Carcinoom:}

Intestinale type: dit type carcinoom is in principe opgebouwd uit klierbuizen die een goed te onderscheiden en ruim lumen bezitten. Er komen papillaire en soliede partijen voor, maar volledig ontbreken van klierbuizen is uiterst zeldzaam. De tumorcellen zijn relatief groot en wel omschreven. Hett celbeeld is gewoonlijk polymorf.

Diffuse type: de tumorcellen liggen verspreid en wel solitair of in kleine celgroepen. Klierbuislumina worden zelden gevonden. Indien aanwezig zijn ze klein en slecht omschreven. Hier en daar vormen de tumorcellen soliede velden, maar ook dan liggen de cellen in een losser verband dan bij het intestinale carcinoom. De tumorcellen zelf zijn kleiner en de celgrenzenzijn vaak moeilijk aan te geven. Het celbeeld is meer uniform.

\section{Polliep:}

Er worden hier twee vormen onderscheiden, mamelijk de adenomateuze en de hyperplastische poliep.

Adenomateuze poliep: deze is opgebouwd uit klierbuizen waarvan het bedekkend epitheel een wisselende mate wan dysplasie laat zien.

Hyperplastische poliep: er bestaat een mengeling van klieren, collageen en gladde spiercellen. De klieren zijn vaak cystisch en bekleed met hyperplastische cellen, welke groot zijn en een kleine basale kern bevatten. Er is een variabele hoeveelheid ontstekingsinfiltraat vooral in het gebied van de erosieve top. 


\subsubsection{Gegevens van de ziektegeschiedenis}

De ziektegeschiedenissen van de carcinoompatiênten werden uitwoerig vermeld. De gegevens werden verkregen vanuit:

- kinische en poliklimische statussen;

- operatieversilagen:

- histologische rapporten;

- mededelingen van patiènten, familieleden, huisartsen, specialisten en de Burgerlijke Stand.

\subsection{Statistische methoden}

Statistische berekeningen werden gedaan met behulp wan de chi-kwadraattoets en de logranktoets.

\section{Hoofdstuk 5}

\section{Endoscopisch en histologisch onderzoek van BII-ma- gen, meer dan 10 jaar postoperatief, in verband met klachten, in de periode 1970 tot en met 1979}

In de periode 1970 tot en met 1979 werden 174 patiënten, meer dan 10 jaar na een BII-resectie, endoscopisch onderzocht in verband met klachten, toegeschreven atan aandoeningen van de restmaag. Vrijwel steeds betrof het hier een combinatie van klachten: verminderde eetllust, vermagering, zuurbranden, opboeren, misselijkheid, overgeven en pijnen in de maagstreek.

In tegenstelling tot de groep patiënten met klachten bij een BII-resectie, geëndoscopieerd in de periode 1980 tot en met 1982, werd dit endoscopisch onderzoek nog niet volgens een standaardprocedure verricht. Bij analyse van deze groep patiënten blijken bij vrijwel alle patiënten biopsieën genomen te zijn uit de stoma- en corpusregio van de restmaag. Echter is er vaak sprake van slechts éen biopsie uit de stoma- en één biopsie uit de corpusregio. De beoordeelbaarheid op histologische fenomenen is niet altijd optimaal, doordat de hoeveelheid via biopsie verkregen materiaal te gering is.

Het bleek mogelijk van de 154 niet-carcinoompatiënten 149 stomabiopsieën en 145 corpusbiopsiezn histologiscli te beoordelen volgens de gestelde crïteria.

Van de 174 patiënten bleken 20 patiènten (19 mannen en 1 wrouw) een carcinoom van de resitmagg te hebben.

Van de carcinoom- en niet-carcinoompatiënten worden de gemiddelde leeftijd op het moment van het onderzoek en het gemiddelde tijdsinterval vanaf de operatie met variatie en standaarddeviatie vermeld in Tabell 5.1.

De gegevens van anamnese, endoscopisch en histologisch onderzoek worden voor beide groepen patiënten (carcinoom- en niet-carcinoompatienten) apart vermeld.

Tabel 5.1. Patiënten met een Bll-maag met klachten, onderzocht meer dan 10 jaar postoperatief in de periode 1970 tot en met 1979

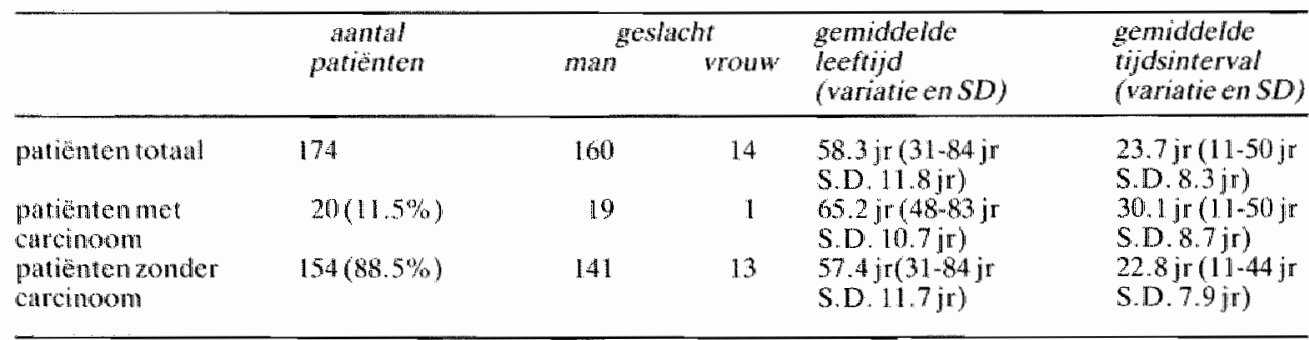




\subsection{Gegevens van de anamnese}

De indicaties voor de primaire operatie worden gegeven in tabel 5.2.

De wanuit de anamnese naar voren komende klachten worden vermeld in Tabel 5.3. en 5.4.

Tabel 5.2. Indicaties voor primaire operatie van de 174 patienten met een BII-maag

\begin{tabular}{|c|c|c|c|c|c|}
\hline & $\begin{array}{c}\text { anantal } \\
\text { patfenten }\end{array}$ & UD & UV & UDORUV & $\begin{array}{l}\text { andere gocdandiga } \\
\text { andoeming }\end{array}$ \\
\hline $\begin{array}{l}\text { pationten met } \\
\text { carcunoom }\end{array}$ & 20 & $6(30 \%)$ & $7(35 \%)$ & $7(35 \%)$ & $\cdots$ \\
\hline $\begin{array}{l}\text { Patienten } \\
\text { zonder } \\
\text { carcinoom }\end{array}$ & 154 & $71(46.1 \%)$ & $9(5.8 \%)$ & $70(45.5 \%)$ & $4(2.6 \%)$ \\
\hline
\end{tabular}

Tabel 5.3. Klachten van de 154 niet-carcinoompatienten met een BlI-maag

\begin{tabular}{lcc}
\hline klachten/aantal patiënter & $\begin{array}{c}\text { ABS } \\
n=154\end{array}$ & $\%$ \\
\hline eetlust verminderd & 62 & 40.3 \\
gewicht verminderd & 66 & 42.9 \\
aantal kg. verminderd* & 424 & 6.4 \\
zuurbranden & 37 & 24.0 \\
opboeren & 55 & 35.7 \\
misselijkheid & 60 & 39.0 \\
overgeven & 41 & 26.6 \\
pijn & 80 & 51.9 \\
druk, opgezet gevoele.d. & 22 & 14.3 \\
\hline
\end{tabular}

* 66 patiènten vermageren in totaal $424 \mathrm{~kg}$.

$=$ gemiddeld $6.4 \mathrm{~kg}$. per vermagerde patiënt

$=$ gemiddeld $2.7 \mathrm{~kg}$. per patiënt

Tabel 5.4. Klachten van de 20 carcinoompatiënten met een Bll-maag

\begin{tabular}{|c|c|c|}
\hline klachren/aantal patiënten & $\begin{array}{c}\overline{A B S} \\
n=20\end{array}$ & $\%$ \\
\hline $\begin{array}{l}\text { eetlust verminderd } \\
\text { gewicht verminderd } \\
\text { aantal kg. werminderd } \\
\text { zuurbranden } \\
\text { opboeren } \\
\text { misselijkheid } \\
\text { overgeven } \\
\text { pijn. } \\
\text { druk, opgezet gevoel e.d. }\end{array}$ & $\begin{array}{c}13 \\
18 \\
182 \\
5 \\
13 \\
8 \\
11 \\
10 \\
5\end{array}$ & $\begin{array}{l}65.0 \\
90.0 \\
10.1 \\
25.0 \\
65.0 \\
40.0 \\
550 \\
50.0 \\
250\end{array}$ \\
\hline
\end{tabular}

* 28 patiēnten vermageren in totaal $182 \mathrm{~kg}$.

$=$ gemiddeld $10.1 \mathrm{~kg}$. per vermagerde patiënt

$=$ gemiddeld $9.1 \mathrm{~kg}$. per patiënt 


\subsection{Gegevens van de endoscopie}

De algemene gegevens van endoscopisch onderzoek van de 154 niet-carcinoom patiënten worden vermeld in Tabel 5.5 .

Tabel 5.5. Agemene endoscopiegegevens van de 154 niet-carcinoom patiënten met een BII-maag

\begin{tabular}{|c|c|c|c|}
\hline \multicolumn{2}{|c|}{ endoscopie gegeven whantal patienten } & \multirow{2}{*}{$\begin{array}{c}\begin{array}{c}A B S \\
n=154\end{array} \\
136 \\
12 \\
6\end{array}$} & \multirow{2}{*}{$\begin{array}{r}\% \\
88.3 \\
7.8 \\
3.9\end{array}$} \\
\hline stoma & $\begin{array}{l}\text { normaal } \\
\text { plooiconvergentie } \\
\text { stenose }\end{array}$ & & \\
\hline stomagastritis & $\begin{array}{l}\text { geen } \\
\text { matig } \\
\text { duidelijk }\end{array}$ & $\begin{array}{r}3 \\
40 \\
111\end{array}$ & $\begin{array}{r}1.9 \\
26.0 \\
72.1\end{array}$ \\
\hline corpusgastritis & $\begin{array}{l}\text { geen } \\
\text { matig } \\
\text { duidelijk }\end{array}$ & $\begin{array}{l}66 \\
78 \\
10\end{array}$ & $\begin{array}{r}42.9 \\
50.6 \\
6.5\end{array}$ \\
\hline thoeveelheid gal & $\begin{array}{l}\text { onbekend } \\
\text { geen } \\
\text { matig } \\
\text { veel }\end{array}$ & $\begin{array}{r}123 \\
3 \\
8 \\
20\end{array}$ & $\begin{array}{r}79.9 \\
1.9 \\
5.2 \\
13.0\end{array}$ \\
\hline
\end{tabular}

Bij de 20 carcinoompatiënten zijn de volgende pathologische bevindingen bij endoscopisch onderzoek gedaan:

patiënt 1: ter hoogte van het stoma aan de grote curvatuur-voorwandzijde ulceratief-proliferatief weefsel, wijzend op een maligne proces;

patiëmt 2. ter hoogte van het stoma aan de voorwand-kleine curvatuurzijde duidelijk geïnfiltreerd slijmvlies, wijzend op een maligne proces;

patiënt 3: ter hoogte van het stoma aan de achterwand-kleine curvatuurzijde grof, gemakkelijk bloedend weefsel, suspect voor een maligne proces;

patient 4: ter hoogte van het stoma diffuus nodulair en stug weefsel, suspect voor een maligne proces;

patiënt 5: ter hoogte van de voorwandzijde van het stoma spekkig, wit gekleurd weefsel; ter hoogte wan de proximale maag proliferatief, gemakkelijk bloedend weefsel; een en ander wijzend op een maligne proces;

patiènt 6: ter hoogte van het stoma aan de kleine curvatuurzijde proliferatief, gemakkelijk bloedend weefsel, wijzend op aen maligne proces;

patient 7: ter hoogte van het stoma aan de kleine curvatuur-achterwandzijde een handpalmgroot star gebied met ulceratieve laesies, gemakkelijk bloedend; $\pm 6 \mathrm{~cm}$ onder de maag-oesophagusovergang proliferatieve plooien ter hoogte van de achterwand-kleine curvatuur-voorwandzijde; een en andet wijzend op een maligne proces:

patiënt 8: ter hoogte van het stoma circulair geïnfiltreerd, ulceratief weefsel, wijzend op een maligne proces;

patiênt 9: ter hoogte van het stoma en praestoma aan de kleine curvatuurzijde grove, onregelmatige, gemakkelijk bloedende plooien, suspect woor een maligne proces;

patiënt 10: ter hoogte van de stoma-en praestomaregio aan de kleine curvatuurzijde forse, wittige plooien, matig suspect voor een maligne proces; 
patient 11: ter hoogte van het stoma aan de kleine curvatuur woorwandzijde proliferatief weefsel, ach tiltbreidend naar de regio oesophagus-maagovergang, wijzend op een maligne proces:

patiënt 12: ter hoogte van het stoma aan de voorwandzijde spekkig geȟnfiltreerd weefsel, zich wibreidend naar proximaal, wijzend op een maligne proces;

patiënt 13: stoma diffuus proliferatief veranderd, wijzend op een maligne proces;

patiënt 14: ter hoogte van het stoma diffuus geïnfiltreerd slijnvlies, wijzend op een maligne proces;

patiënt 15: ter hoogte van het stoma aan de achterwand naar het lumen prominerend geïnfiltreerd weefsel, wijzend op een maligne proces;

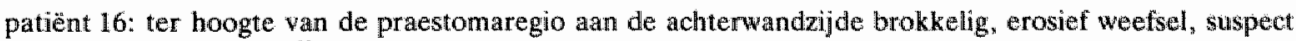
voor een maligne proces;

patiënt 17: twee tot drie cm proximaal van het stoma aan de voorwand kleine curvatuurzijde een klein wittig gebiedje, gemakkelijk bloedend, niet duidelijk maligne van aspect;

patiënt 18: ter hoogte wan de proximale maag aan de woorwand klleine curvatuurzijde een ulceratief-proliferatief proces, zich uitbreidend naar de oesophagus " wijzend op een maligne proces"

patiënt 19: ter hoogte van de proximale maag aan de kleine curvaturaijde uitgebreid proliferatief proces, wijzend op een maligne proces;

patiënt 20: ter hoogte van de distale oesophagus spekkig geïnfiltreerd weefsel, niet te passeren met de endoscoop, wijzend op een maligne proces.

Van de 20 carcinoompatiënten wees het endoscopisch onderzoek in 14 gevallen duidelijk op een maligne proces; viermaal was er sprake van een suspect beeld (patiënt 3,4, 9 en 16), eenmaal van een matig suspect beeld (patiënt 10), terwijl eenmaal een wittig gebiedje gezien werd (patiënt 17), niet duidelijk suspect voor maligniteit.

Het carcinoom bleek 15 maal ter hoogte van het stoma gelocaliseerd te zijn (waarbij zesmaal met uitbreiding corpuswaarts), tweemaal ter hoogte van de praestomaregio (patiënt 16 en 17), tweemaal ter hoogte van de proximale maag (patiënt 18 en 19), terwijl eenmaal het carcinoom bleek doorgegroeid te zijn naar de oesophagus (patiënt 20), waarbij de uitgebreidheid van het proces ter hoogte van de maag niet kon worden vastgesteld (zie figuur 5.1).

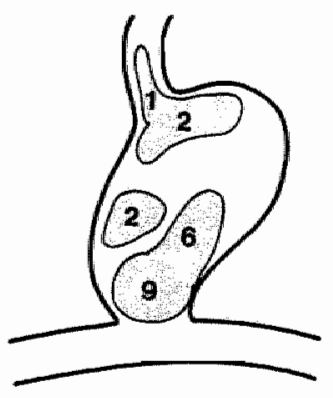

Figuur 5.1.

Localisatie van de 20 carcinomen in de Blf-maag 
Tabel 5.6. Bijzondere endoscopische bewhingen bij de 154 miet-carcinoom patiènten met een BII-maag

\begin{tabular}{lc}
\hline endoscopiegegeventantapationten & $A B S$ \\
& $n=154$ \\
\hline
\end{tabular}

forse plooien stoma

jejunumslingul ies op rand foma

wiltige plekken stoma/corpus

ulcus pepticum jejuni

ulcus stoma

ulcus pracstoma

erosie jejunum

erosiestoma

xantelasmata

suspecte tumor stoma

oesophagitis

oesophagusearcinoom

$\begin{array}{rr}17 & 11.0 \\ 3 & 1.9 \\ 9 & 5.8 \\ 10 & 6.5 \\ 3 & 1.9 \\ 2 & 1.3 \\ 2 & 1.3 \\ 1 & 0.6 \\ 5 & 3.2 \\ 1 & 0.6 \\ 5 & 3.2 \\ 1 & 0.6\end{array}$

Bij de niet-carcinoom patiënten werd énmaal endoscopisch een voor een maligne proces zeer verdacht beeld gezien: een kastanjegrote hobbelige tumor, fors bloedend bij biopsie. Bij histologisch onderzoek van genomen biopten en hierop volgende operatie kon het maligne karakter van deze afwijking niet worden bevestigd.

De overige bijzondere endoscopische bevindingen bij deze 154 niet-carcinoom patiënten worden vermeld in Tabel 5.6 .

\subsection{Gegevens van histologisch onderzoek}

De resultaten van histologisch onderzoek van de niet-carcinoompatiënten worden vermeld in Tabel 5.7. Hierbij dient opgemerkt te worden dat van 149 patiènten stomabiopten, van 145 patiënten corpusbiopten voor histologisch onderzoek beschikbaar waren.

Bij histologisch onderzoek van de bij endoscopie genomen biopten werd 17 maal de diagnose maligne proces van de restmaag bevestigd. Driemaal kon histologisch onderzoek van deze biopten geen definitieve bevestiging van de diagnose geven (eenmaal suspecte cellen, tweemaal chronische ontsteking met enige atypie). Bij 2 patiënten werd bij PA-onderzoek van het resectiepreparaat de diagnose carcinoom histologisch bevestigd. De derde patiènt werd niet geopereerd, overleed cachectisch onder het beeld van levermetastasen (klinisch, biochemisch en via leverscan vastgesteld); een obductie bevestigde de diagnose carcinoom van de restmaag.

Bij 13 pationten bleek een carcinoom van het intestinale type aanwezig te zijn, bij 7 patiënten een carcinoom wan het diffuse type.

Zover mogelijk werd het stoma van deze carcinoompatiënten beoordeeld op een dysplasie: zevenmaal bleek het stoma hierop niet te beoondelen (diffuus doorgroeid met carcinoom), viermaal toonde het stoma geen dysplasie, tweemaal een lichte dysplasie, driemaal een matige dysplasie, terwiji viermaal gegevens hiervan niet te achterhalen waren.

Bij 17 patiënten zijn er wia onderzoek (histologisch onderzoek van bij endoscopie verkregen material en wan het resectiepreparaat, preoperatief verricht biochemisch onderzoek en isotopenscan-onderzoek, operatie) argumenten naar voren gekomen pleitend voor het bestaan van een uitgebreid maligne proces.

Bij 2 niet geopereerde patiënten (patiènt 10 en 15) is er mogelijk sprake geweest van een niet uitgebreid carcinoom met eventueel redelijke prognose (klinisch beloop wijst hier niet op!), bij 1 patiënt (patiënt 17) leek een vrij beperkt carcinoom aanwezig, echter bleek het proximale resectievlak maligne cellen te tonen. 
Tabel 5.7. Gegevens van histologisch onderzoek van de 154 niet-carinoom patièten met een Bli-maag (149 stoma- en 145 corpusbiopsieèn)

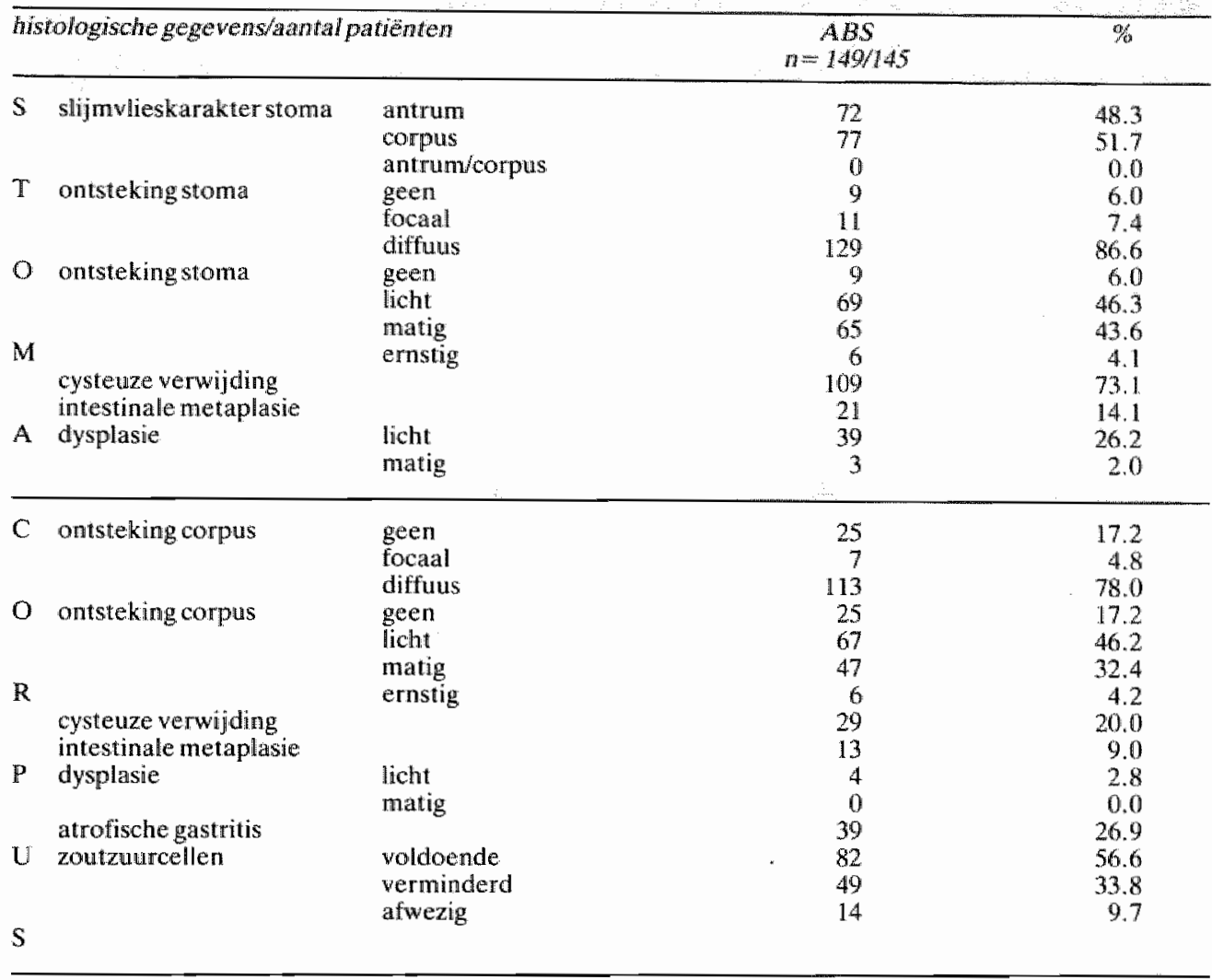

Bij l patiënt werd endoscopisch een voor een maligne proces verdachte hobbelige tumor ter hoogte van het stoma gezien, histologisch onderzoek van bij operatie genomen biopten kon dit vermoeden niet bevestigen.

Van de 9 niet-carcinoompatiënten met wittige slijmvliesplekken ter hoogte wan hel stoma toonde histologisch onderzoek in alle gevallen een duidelijk intestinale metaplasie, bij 1 patient in combinatie met matige dysplasie aanwezig.

Bij slechts 3 niet-carcinoompatiënten (gemiddelde leeftijd 59.0 jaar, gemiddeld interval 15.7 jaar) werd ter hoogte van het stoma een matige dysplasie gezien. Dit geringe aantal patiënten met een matige dysplasie is mogelijk toe te schrijven aan het feit, dat van patiënten uit deze groep vaak niet meer dan één stoma-biopt genomen werd. Endoscopisch werd bij 1 patiënt met matige dysplasie een wittig slijmvlies ter hoogte van het stoma gezien, berustend op een intestinale metaplasie. Van de overige histologische gegevens van deze 3 patiënten is te mellden dat ter hoogte van het stoma tweemaal een diffuus matige ontsteking, eenmaal een diffuus lichte ontsteking gezien werd, driemaal een cysteuze verwijding van klierbuizen aanwezig bleek, tweemaal een intestinalle metaplasie; ter hoogte van het corpus werd eenmaal geen afwijking vastgesteld, eenmaal een diffuus matige ontsteking met duidelijke afname van zoutzuurcellen, cenmaal een diffuus ernstige ontsteking. Het endoscopisch onderzoek van deze 3 patiënten werd niet herhaald, alle 3 patiënten verkeren in februari 1983 in goede algemene conditie $(7,11$ en 12 jaar na vermeld histologisch onderzoek waarbij een matige dysplasie werd vastgesteld). 


\subsection{Ziektegeschiedenis van de carcinoompatiënten}

patient 1: man, geboren in 1892, BM- resecte in 1950 in verband met ulcus ventriculi. Geen magklachten in intervalperiode. In janumi 1971 werd gastroscopie werricht in werband met 2 maanden bestaande klachten over pijnen in epigastrio, gevoelens van misselijkheid, af en toe overgewen; bij goede cettust was patient hiet wermagerd. Gastroscopie: middelgrone BIl-resectiemalag; ter hoogte var stoma aan grote curvituwr-woorwandzijde viceratef-prolferatief proces, ongetwijeld maligne wan ard; corpusslijm wes met duidelijk afwijkend. Histologisch bleek een carcinom van het intestinale type anwezig. Operatie toonde aam dat het carcinoom inoperabel was. Patiènt is overleden in februari $\| 971$.

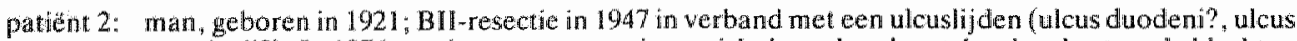
wentriculi?). In 1976 werd een gastroscopie verricht in verband met 4 weken bestaande klachten over verminderde eetlust, pijnen in epigastrio. In verband met een chronisch rbeumatoide arthriwis werd patièn behandeld met analgetica. Bij gastroscopie werd een matige stomagastritis, een geringe corpusgastritis vastge steld, ter hoogte van de distale oesophagus waren wittige beslagen zichtbaar. Bij histologisch onderzoek bleek een licht chronische stomamontsteking aanwezig "een matig chronische ontstek ng met intestinale metaplasie wan het corpus van de maag. In juli 1979 werd opnieuw gastroscople verricht in verband met 6 manden bestaande klachten over pinen in epigastrio rechts, gewichtsverlies van $16 \mathrm{~kg}$. ondanks goede eetlust. De lever bleek onregelmatig vergroot te zijn, eeru leversean toonde het beeld wan uitsparingen. Gastroscopie: middelgrote BII Hestetienaag, duidelijk geinfiltreerd slijmvlies ter hoogte van stoma an de voorwand-kleine curvatuurzijde, wijzend op een maligne proces; het corpus van de mag toonde geen bijzonderheden. Histologisch onderzoek toonde stomaslijmwlies wan het corpustype, tekenen van een gering chronische ontsteking, overigens geen bijzonderheden; het corpusslijmvlies toonde een inthestinale metaplasie, overigens evenmin bijzonderheden.

Operatie heeft niet platsgevonden, in augustus 1979 is patiènt cachectisch overleden. Bij obducthie werd ter hoogte van het stoma van de restmag een vrij uitgebreid carcinoom van het intestinalle type vastgesteld met uitgebreide metastasen onder andere in de lever.

patient 3: man, geboren in $1930 ;$ Bll-resectie in 1950 in verband met een ulcusperforatie (ullcus duodent? ulcus ventriculi?). In september 1978 werd een gastroscopie verricht in verband met enkele weken bestaande klachten over werminderde eethust, gewichtsverlies wan $6 \mathrm{~kg}$. jetwat zuurbranden, opboeren, gevoelens wan misselijkheid, af en toe overgeven, pijnen ter hoogte van de bovenbuik median.

Gastroscopie: middelgrote BI-Tesectiemaag; ther hoogte van stoma an achterwand-kleine curvatuurzijde grofplooig, gemakkelijk bloedend weefsel, suspect voor een maligne proces; het corpus van de magg toonde geen bijzonderheden. Histologisch onderzoek toonde een carcinoom van het diffuse type, het stomasijmvlies toonde overigens een diffur matige ontsteking, intestinale metaplasie en lichte dysplasie. Bij operatie werd ter hoogte wan de anastomose een harde tumor gevoeld, langs de kleine curvatuurzijde in het mesenterium waren grote klieren aanwezig. Een subtotale magresectie vond plats. Het resectiepreparaat toonde dik, vast aanvoelend slijmvlies in de regio stoma-kleine curvatuurzijde over een afstand van 10 tot $12 \mathrm{~cm}$. Er bleken wexl lymfkliermetaskasen aanwezig te zijn. Postoperatief hebben er zich geen problemen voorgecaan. In januti 1979 werd patiënt met ileusklachten in het ziekenhuis opgenomen, cen duidelijke ascites bleek aanwezig. Patiënt is overleden in februari 1979.

patient 4: wrouw, geboren in 1922; Bll-resectie in 1946 in verband met ulcus duodeni. Tot februari 1975 was patiente geheel klachtenwrij geweest. Vanaf dit moment klagde zij over retrosternaal blijwen steken van voedsel, opboeren, overgeven, gewichtsverlies wan $7 \mathrm{~kg}$. bij redelijke eetlust. Gastroscopie april 1975: middelgrote BI-resectiema:g; ler hoogte van stoma diffuus nodulair en stug weefsel, suspect woor een maligne proces; ter hoogte van corpus zeer forse plooien, niet geinfiltreerd lijkend. Histologisch onderzoek toonde en carcinoom van het diffuse type. Een operatie werd vertichi, watrbij een geindureerde retrocolische Billroth-II anastomose gezien werd, waarbij tevens de grote curvatuur geindureerd bleek te zijn doorgroei bestond naar het omringende weefsel. Een subtotale magresectie werd verricht, warbij tevens een stuk wan het colon tramsversum, de milt, $2 \mathrm{~cm}$. pancreasstaart werd meegenomen. Het resectiepreparaat toonde een diffuus groeiend maagcarcinoom met uitbreiding tot in het orale resectievlak en in het peritoneale vetweefsel. De tweede dag postoperatief is patiente acuut kortademig en cyanotisch geworden en onder het beeld van een longembolie overleden.

patient 5: man. geboren in 1922; BII-resectie in 1948 in verband met ulcus duodem. Sedert operatie klachlenvrij. Cerebrovasculair accident 1972. In april 1974 werd een gastroscopie verricht in verband

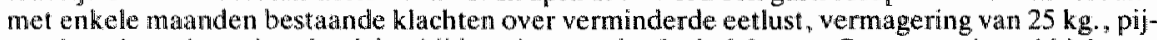
nen in epigastrio en braakneiging bij lang bestaande alcoholabusus. Gastroscopie: middelgrote Bli-fesectiemagg; ter hoogte van voorwandrijde stoma spekkig, wit gekleurd weefsel, ter hoogte 
van proximale maag proliferatief, gemakkelijk bloedend weefsel, een en ander wijzend op een maligne proces. Histologisch onderzoek wees op het bestalan wan een carcinoom van het intestinale type; ter hoogte van het stoma werd intestinale metaplasie met matige dysplasie gezien; het corpus van de maag toonde een atrofische gastritis, intestinale met aplasie, sterk verminderd antal zoutzuurcellen. Gezien het cerebrovasculair accident in 1972 en het biochemisch beeld vam levermetastasen, werd afgezien van operatie. Patient is owerleden in mei 1974.

patiënt 6: man, geboren in 1898; BII-resectie in 1929 in verband met ulcus duodeni. In 1974 werd een gastroscopie verricht in verband met verminderde eetlust, vermagering van 4 tot $5 \mathrm{~kg}$, opboeren en zuurbranden. Een middelgrote BU-resectiemaag bleek aanwezig, het stoma toonde ietwat wittig slijmvlies, gemakkelijk bloedend bij aanraken met de endoscoop, geen proliferatieve laesies; de overige maag toonde geen bijzonderheden. Histologisch onderzoek toonde een minimale ontsteking ter hoogte wan het stoma, intestinale metaplasie en plaatselijk een lichte dysplasie; het corpusslijmvlies toonde een superficiële ontsteking met intestinale metaplasie, geringe dysplasie en duidelijke atrofie. In november 1977 werd opnieuw een gastroscopie verricht in verband net enkele maanden bestaande klachten over verminderde eetlust, gewichtsverlies van $4 \mathrm{~kg}$.. Gastroscopie: middelgrote BlI-resectiemaag, ter hoogte van stoma wittig weefsel, ter hoogte van kleine curvatuurzijde stoma proliferatief, gemakkelijk bloedend weefsel, wijzend op maligne proces: proximale maag atrofisch slijmvlies. Histologisch onderzoek wees op het bestaan van een carcinoom van het diffuse type. Ter hoogte van het stoma werd overigens intestinale metaplasie en locaal lichte dysplasie vastgesteld.

Bij operatie werd een partiële reresectie verricht. Het resectiepreparaat toonde een circulair tumoreuze verdikking ter hoogte van het stoma, over een afstand wan ongeveer $3 \mathrm{~cm}$, er bestond infiltratie van de muscularis propria. Het slijmwlies toonde ontstekingsverschijnselen, een sterk intestinale metaplasie. Het proximale resectievlak bleek niet wrij wan tumor te zijn, toonde tevens een duidelijke dysplasie. Postoperatief hebben er zich geen problemen voorgedaan. In mei 1982 werd opnieuw een gastroscopie verricht in verband met verminderde eetlust en vermagering. Er was een kleine Bll-resectiemaag, het stoma toonde circulair wallig geinfilttreerd en sanguinolent slijmvlies, zich uitbreidend via de achterwand; het corpusslijmvlies was wittig van kleur, atrofisch van aspect; ter hoogte wan de distale oesophagus was ietwat spekkig slijmvlies zichtbaar. Histologisch onderzoek toonde een carcinoom wan het diffuse type in het stomagebied, met doorgroei tot in de submucosa van de distale oesophagus. In november 1982 is patiënt cachectisch overleden.

patiênt 7: man, geboren in 1906; Bll-resectie in 1939 in verband met een ulcus (ulcus duodeni?, ulcus ventriculi?). In mei 1967 werd röntgenonderzoek van de maag verricht in verband met een tractus digestivusbloeding: er werd een BII-tesectiemaag met zeer grove plooien gezien, mogelijk een ulcus ventriculi proximaal van het stoma aan de grote curvatuurzijde. Patiênt werd conservatief behandeld. In september 1970 volgde een gastroscoplie in verband met pijnen in epigastrio, gewichtsverlies wan $9 \mathrm{~kg}$. bij goede eetlust. Gastroscopie: middelgrote BII-resectiemaag, ter hoogte van stoma aan kleine curvatuur-achterwandzijde handpalmgroot star gebied met ulceratieve laesies, gemakkelijk bloedend; $\pm 6 \mathrm{~cm}$ onder maag-oesophagusovergang proliferatieve plooien ter hoogte wan achterwand-kleine curvatuur-voorwandzijde, een en ander wijzend op maligne proces. Histologisch onderzoek toonde een carcinoom van het intestinale type. Bij operatie werd ter hoogte van de anastomose een harde tumor gepalpeerd, vastzittend aan het colon transwersum. Er werd een resectie van de magstomp tot ruim boven de tumor verricht, een deel van het colon transwersum werd gereseceerd. Het resectiepreparat toonde bij thet stoma ter hoogte van de achterwandzijde een grote ulcererende tumor, $7 \mathrm{~cm}$ in doorsnee, met opgeworpen rand en diepe bow dem. Histologisch was een carcinoom van het intestinale type atnwezig, met doorgroei tot bij de serosa en ingroei in het colon transversum. Ongeveer 24 uar postoperatief klaagde patient over heftige buikpijnen, overleed onder het beeld van een shock. Bij obductie werd een naadlekkage, het beeld van een peritonitis vastgesteld.

patiënt 8: man, geboren in 1908; BII-resectie in 1947 in verband met een ulcus ventriculi. In aprill 1975 werd een gastroscopie verricht in werband met 4 maanden bestaande klachten over verminderdte eetlust, vermagering van $7 \mathrm{~kg}$, opboeren, pijnen ter hoogte van de bovenbuik medialan. Gastroscopie: middelgrote BII-resectienaag; ter hoogte van stoma circulail geinfiltreerd en ulceratief weefsel, wijzend op maligne proces; corpus van de maag geen bijzonderheden. Histologisch onderzoek toonde een carcinoom van het intestinale type. Bij operatie werd een harde tumor ter hoogte wan de anastomose gepalpeerd, er volgde een resectie ruim boven da tumor. Het resectiepreparaat toonde ter hoogte van het stoma een ulceratieve laesie met opgeworpen randen, $7 \times 2$ $\mathrm{cm}$ groot. Histologisch bleek een carcinoom van het intestinale type aanwezig tot dicht bij de se. rosa. Postoperatief hebben er zich geen problemen voorgedaan. In december 1975 werd een epiglottiscarcinoom (matig gedifferentieerd plaveiselcelcarcinoom) gediagnostiseerd. Patient is overleden in maart 1976.

patiën 9: man, geboren in 1928; Bll-resectie in 1952 in verband met ulcus duodeni. In juli 1977 werd cen gastroscopie verricht in verband met 6 maanden bestaande klachten over pijnen in epigastrio, gewichtsverlies van $2 \mathrm{~kg}$. bij goede eetlust, misselijkheid en overgeven. Gastroscopie: middelgrote 
BH wesectiemaag; ter hoogte van het stona en praestoma aan de kleine curvatuurzijde grove, onregelmatig, gemak kelijk bloedende plooien, suspect voor een maligne proces; overige matag \pm rood sijmulies, ietwat atrofisch van aspect. Histologisch onderzoek toonde een carcinoom van het intestinale type; ter hoogte van het stoma werd intestinale metaplasie, een matige dysplasie vasitgesteld; het corpus toonde eveneens intestinale metaplasie, en atrofische gastritis met afwezigg zijn van zoulzuncellen. Een subtotale maagresectie met Roux-Y-anastomose werd verricht. Macroscopisch toonde het resectiepreparat ter hoogte van het stoma een duidelijk werdikte wand, grofhobbelig slijmulies. Histologisch waseen carcinoom van het intestinale type aanwezig. met doorgroei tot in de sub-serosa, groei in perineurale lymfespleten; de resectievlakken waren vrij, er waren geen lymfkllermetastasen. Postoperatief hebben er zich geen problemen voorgedaan. Vanaf april 1980 klaggde patient in progressieve mate ower buikpijnaanvallen, in verband met een ileusbeeld volgde een operatie in augustus 1980, waarbij metastasen in de gehele buik werden vastgesteld. Na enkele cytostaticakuren met aanvankelijk redelijk succes, overleed patient in jantuari 1981.

patient 10: man, geboren in 1902; BII-resectie in 1930 in verband met ulcuslijden (ulcus duodeni?, ulcus ventriculi?). In september 1973 werd een gastroscopie verricht, omdat patiënt enkele maanden klaggde over een steengevoel ter hoogte van de bovenbuik, misselijkheid, overgewen, vermagering van $32 \mathrm{~kg}$. bij redelijke eetlust. Gastroscopie: middelgrote BII-resectiemaag; ter hoogte van kleine curvatuurzijde stoma forse, wittige plooien, matig suspect voor een maligne proces, owerige maag geen bijzonderheden. Histologisch werd een carcinoom van het diffuse type vastgesteld, elders toonde het stoma geen bijzonderheden. Een operatie werd door patient geweigerd, in september 1973 is patient cachectisch overleden.

patiènt 11: man, geboren in 1922; B11-resectie in 1951 in verband met ulcus verntriculi. In december 1978 werd een gastroscopie verricht in verband met 3 maanden bestaandle klachten over verminderde eetlust, gewichtsvermindering van $10 \mathrm{~kg}$, opboeren en overgeven. Gastroscopie: middelgrote BIl-resectiemaag; ter hoogte van stomen an kleine curvatuur-voorwandzijde proliferatief weefsel, zich uitbreidend naar regio malg-oesophagusovergang, wijzend op een maligne proces. Hisfologisch werd aen carcinoom wan het intestinale type wastgesteld. Een subtotale magresectie met Roux-Y-anastomose werd verricht. Het resectiepreparat toonde een grote tumormassa ( $8 \mathrm{x}$ $7 \mathrm{~cm}$ ) vanaf het stoma tot in de proximale resectierand. Lymfkliermetastasen waren aanwezig. Postoperatief hebben er zich geen problemen voorgedaan. In april 1979 werd patiënt in het ziekenhuis ter observatie opgenomen in verband met verder gewichtsverlies. Algemeen oriënterend onderzoek toonde geem bijzonderheden (gastroscopie niet verricht!). In december 1981 is patiënt cachectisch overleden.

patiënt 12: man, geboren in 1897; BII-resectie in 1948 in verband met ulcuslijden (ulcus duodeni?, ulcus ventriculi?). In december 1977 werd een gastroscopie verricht in verband met 3 malanden bestaande klachten over cen opgeblazen gevoel in epigastrio, verminderde eetlust, vermagering van $2 \mathrm{~kg}$., opstoten van voedsel Overigens bleken een diabetes mellitus, boezemfibrilleren, claudicatio intermittens aanwezig. Gastroscopie: vrij kleine BII-resectiemaag; nauw stoma ter hoogte van voorwandzijde spekkig geinfiltreerd, met uitbreiding naar proximaal, wijzend op maligne proces; overigens toonde het corpus geen bijzonderheden. Histologisch anderzoek wees op het bestam van een carcinoom van het diffuse type. Bij operatie werden ter hoogte van de bovenbuik zeer uitgebreid vergroeingen gezien, een tumor was palpabel ter hoogte van de anastomose met doorgroei naar pancreas en colon. Van resectie werd afgezien. Postoperatief hebben er zich geen problemen woorgedaan, patiënt is overleden in december 1977.

patiènt 13: man, geboren in 1905: BII-resectie in verband met ulcus ventriculi. In 1944 werd een cholecystectomie verricht in verband met een galsteenlijden. Een gastroscopie volgde in augustus 1973 in werband met 6 manden bestalande klachten over verminderde eetlust, vermagering van $13 \mathrm{~kg}$., opboeren en overgeven. Gastroscopie: middelgrote Bll-resectiemaag; veel retentiemateriaal, stoma diffuus proliferatief veranderd, wijzend op maligne proces, corpus toonde matig geinjiceerd slijmvlies. Histologisch onderzoek toonde een carcinoon van het intestinale type. Bij operatie werd een harde tumor ter hoogte van de anastomose gepalpeerd, in de omgeving waren vele tumortjes zichtbaar, het peritoneum was bezaaid met witte spikkels. Waar de tumor inoperabel was, werd een antecolische gastro-enterostomie angelegd. Postoperatief hebben er zich geen problemen voorgedaan. In januari 1974 is patiënt cachectisch overleden.

patient 14: man, geboren in 1905; BII-resectie in 1946 in verband met ulcusperforatie (ulcus duodeni?, ulcus ventriculi?), Na de operatie hebben er zich geen maagproblemen voorgedaan. In november 1976 werd een gastroscopie verricht in verband met klachten over vermagering van $5 \mathrm{~kg}$. bij goede eetlust, opboeren en overgeven. Gastroscopie: middelgrote BIl-resectiemaag met veel gallig retentiemateriaal, vernauwd stoma met diffuus geinfiltreerd slijmvlies, wijzend op maligne proces; overige maag niel goed te beoordelen ten gevolge van retertie; rood vlekkerig slijmwlies ter hoogte van distale oesophagus. Een carcinoom van het intestinale type bleek histologisch aanwe- 
zig te zijn. Bij operatie werd een wistgrote tumor gepalpeerd ter hoogte van de anastonose, er waren talrijke pathologische lymfklieren; enkele peritoneale uitzaaiingen. Fen Roux-Y-anastomose werd op het corpus van de maag aangelegd. Postoperatief hebben er zich geen problemen voorgedaan. In augustus 1977 is patiènt overleden.

patiënt 15: man, geboren in 1894, BII-resectie in 1948 in verband met een tucus ventriculi. In januari 1977 werd in het kader van een analyse van een anaemie een gastroscopie verricht. Maagklachten waren in lichte mate aanwezig. Gastroscopie: middelgrote Bll-resectiemaads; ter hoogte wan stoma aan achterwandzijdie naar lumen prominerend geinfiltreerd weefsel, wijzend op maligne proces: overige maag geen bijzonderheden. Histologisch onderzoek wees op het bestaan van een carcinoom van het intestinale type; het corpusslijmvlies toonde een atrofische gastritis met sterk verminderd aantal zoutzuurcellen. Van een operatieve ingreep werd afgezien in verband met een coronairsclerose en silicosis pulmonum. Patient is progressief achteruitgegaan, in augustus 1978 cachectisch overledien.

patient 16: man, geboren in 1908; BlI-resectie in 1948 in verband met ulcus duodeni, gevolgd door vagotomie in 1949 in verband met ullcus pepticum jejuni. In september 1974 werd een gastroscopie verricht in verband met 1,5 jaar bestaande klachten over een gespamen geveel in epigastrio, verminderde eetlust, gewichtsverlies van $17 \mathrm{~kg}$, opboeren, misselijkheid en brakneiging. Gastroscopie: middelgrote BII-resectiemalag; ter hoogte van praestomaregio aan achterwandzijde brokkelig erosief weefsel, suspect voor een maligne proces; beeld matige gastritis ter hoogte van corpus van de maag. Histologisch bleek een carcinoom van het diffuse type aanwezig; overigens werden geen afwijkingen van betekenis wastgesteld. Bij operatie werd een harde massa ter hoogte van de anastomose vastgesteld, metastasen ter hoogte van het mesenterium. De tumor bleek inoperabel. Postoperatief hebben er zich geen problemen voorgedaan. In maatt 1975 is patient cachectisch overleden.

patiënt 17: man, geboren in 1918; BII-resectie in 1952 in verband met ulcus duodeni. In augustus 1973 werd een gastroscopie verricht in verband met 6 maanden bestaande klachten over verminderde eetlust, gewichtsverlies van $2 \mathrm{~kg}$., drukgevoel in epigastrio. Gastroscopie: middelgrote BII-resectiemaag; 2 tot $3 \mathrm{~cm}$ proximaal van stoma aan voorwand-kleine curvatuurzijde, $k$ lein wittiggebiedje, gemakkelijk bloedend, niet duidelijk maligne van aspect, overige maag geen bijzonderheden. Bij histologisch onderzoek bleek een carcinoom van het diffuse type aanwezig; het stomaslijmvlies toonde enige intestinale metaplasie, geen dysplasie; het corpus van de maag toonde histologisch geen bijzonderheden. Een partiële maagresectie werd verricht, het maagresectiepreparaat toonde even proximaal van de anastomose een oneffen slijmvlies $(2 \times 1,5 \mathrm{~cm})$. Histologisch onderzoek toonde een carcinoom van het diffuse type, groeiend tot in de submucosa, in het proximale sneevlak werden maligne cellen gezien. Postoperatief thebben er zich geen bijzonderheden voorgedaan. Tot ok tober 1980 was patiënt klachtenvrij. In oktober 1980 volgde een opname in het ziekenhuis in verband met een bloeding. Bij gastroscopie werd aan kleine curvatuur-achterwandzijde van het stoma een groot ulcus gezien, 2 tot $3 \mathrm{~cm}$ in doorsnee, niet duidelijk maligne van aspect; de stomarand toonde aan de grote curvatuur-voorwandzijde een wittig slijmvlies met oppervlakking ulceratieve laesie. Histologisch werd een carcinoom van het diffuse type vastgesteld. Bij operatie bleek de maagrest geheel geinfiltreerd te zijn, er waren veel kleine metastasen ter hoogte van omentum, mesocolon, mesenterium en kleine bekken. Un mart 1981 is patient ca* chectisch overleden.

pattënt 18: man, geboren in 1909; Bll-resectie in 1963 in verband met ulcus pylori. In december 1974 werd een gastroscopie verricht in werband met én jaar bestaande klachten over verminderde eetlust, gewichtsverlies van $13 \mathrm{~kg}$, gevoelens van misselijkheid. Gastroscopie: middelgrote BII-resectiemaag; fraai stoma zonder bijzonderheden; ter hoogte van proximale maag aan voorwand-kleine curvatuurzijde ulceratief-proliferatief proces, zich uitbreidend naar de oesophagus, wijzend op maligne proces. Histologisch onderzoek toonde een carcinoom van het intestinale type. Een operatie werd niet verricht. In november 1976 is patiënt overleden.

patiënt 19: man, geboren in 1903; BII-resectie in 1927 in verband met ulcuslijden (ulcus duodeni?, ulcus ventriculi?). In oktober 1971 werd een gastroscopie verricht in verband met 2 maanden bestaande klachten over verminderde eetlust, vermagering van $7 \mathrm{~kg}$., opboeren, laag retrosternaal blijven steken wan voedsel. Gastroscopie: middelgrote BII-resectiemag met veel retentiemateriaal "stoma zover te beoordelen niet duidelijk afwijkend; ter hoogte van proximale maag aan kleine curwaturzijde uitgebreid proliferatief proces, maligne van aard; tekenen schimmelinfectie oeso phagus. Histologisch bleek een carcinoom van het intestinale type aanwezig. Bij operatic bleek de gehele maagrest doorgroeid met carcinoom, er bestond eveneens doorgroei naar pancreas en mesocolon transwersum. Postoperatief hebben er zich geen problemen voorgedan. Patiènt iscachectisch overleden in januari 1972. 
patiervit 20: man, geboren in 1911 ; B11-resectie in 1945 in verband met ulcus ventriculi. In oktober 1975 werd een gastroscopie verricht in verband met 2 maanden bestaande klachten over verminderde eetlust, gewichtsverlies wan $6 \mathrm{~kg}$, vol gevoel in epigastrio met opboenen, af en toe overgeven. Gastrosicopie: de distalle oesophagus toonde spekkig geinfiltreerd weefsel, niet te passeren met de endoscoop. Histologisch onderzoek wees op het bestaan van een carcinoom van het intestinale type. Bij operatie werd een oesophago-jejunostomie met Braunse anastomose aangelegd, war het maagcarcinoom inoperabel bleek te zijn. Postoperatief hebben er zich geen problemen voorge. daan. In april 1976 volgde cen operatie in verband met een ileusbeeld: de maag was niet te mobiliseren, ter hoogte van het sigmoïd was een harde tumor palpabel, ter hoogte van het pancreas werd een grote cyste gezien, overigens geen duidelijke tekenen wan metastasen. In augustus 1976 is patiënt overleden onder het beeld wan een trombosebeen en longembolieën; bij obductie werd cen uitgebreid margcarcinoom met $0 . a_{\text {. }}$ levermetastasen vastgesteld.

\subsection{Samenvatting van de onderzoekgegevens}

Uit dit onderzoek komen de volgende gegevens naar voren:

- bij 174 patiënten (gemiddelde leeftijd 58.3 jaar, gemiddeld interval 23.7 jaar) met maagklachten, endoscopisch en histologisch onderzocht in de periode 1970 tot en met 1979 , meer dan 10 jaar na een BII-resectie, werd bij 20 patiënten (gemiddelde leeftid 65.2 jaar, gemiddeld interval 30.1 jaar) histologisch een carcinoom wastgesteld (13 mal van het intestinale type, zevenmaal van het diffuse type);

- het klachtenpatroon van de carcinoompatiënten verschilde niet significant van dat van de nietcarcinoompatiënten; bij de carcinoompatiënten bleken meer klachten in combinatie aanwezig, de carcinoompatiënt vermagerde gemiddeld $9.1 \mathrm{~kg}$., de niet-carcinoompatiënt gemiddeld 2.7 $\mathrm{kg}$; ;

- bij de 20 carcinoompatiënten bleek ter hoogte van het stoma een matige dysplasie slechts driemaal aanwezig te zijn, waarbij aangetekend dat het stoma hierop bij 7 patiënten niet te beoordelen was, gegevens van 4 andere patiënten niet te achterhalen waren;

- bij geen van de 20 carcinoompatiënten kon de maligne tumor radicaal verwijderd worden; theoretisch zou dit mogelijk bij 3 patienten het geval geweest kunnen zijn, bij de overige patiënten bleck een radicale operatie niet mogelijk door uitgebreidheid van het proces, doorgroei in de directe omgeving of metastasen op afstand;

- bij 9 niet-carcinoompatiënten werden bij endoscopie wittige slijmvliesplekken ter hoogte van het stoma gezien, bij al deze patiënten bleek histologisch een duidelijk intestinale metaplasie aanwezig, eenmaal in combinatie met een matige dysplasie ter hoogte van het stoma;

- bij 3 niet-carcinoompatiënten werd ter hoogte van het stoma histologisch een matige dysplasie gezien, her-endoscopie van deze patiënten heeft niet plaatsgevonden; 7,11 en 12 jaar na deze bevindingen verkeren deze patiënten in goede algemene conditie;

- zeer frequent werd histologisch ter hoogte van het stoma een cysteuze verwijding van de klierbuizen gezien $(73.1 \%)$, hetgeen opgewat kan worden als een kenmerkend afwijkende bevinding van het stomaslijmulies. 


\section{Hoofdstuk 6}

\section{Endoscopisch en histologisch onderzoek van BII-ma- gen, meer dan 10 jaar postoperatief, in verband met klachten, in de periode 1980 tot en met 1982}

In de periode 1980 tot en met 1982 werden 118 patiënten met een meer dan 10 jaar tevoren verrichte BII-resectie onderzocht in werband met klachten, toegeschrewen aan aandoeningen van de resectiemaag. Het betrof hier een combinatie van klachten: verminderde eetlust, vermagering, pijn in de maagstreek, zuurbranden, opboeren, misselijkheid en overgeven. In deze periode werden volgens een vastgestelde procedure woor histologisch onderzoek 4 of meer biopten genomen zowel ter hoogte van het stoma als ter hoogte van het corpus van de restmaag. Waar het hier vrijwel altijd ruime biopten betrof, kon histologisch onderzoek hiervan zonder problemen plaatsvinden.

Van deze 118 patiënten bleken 14 patiënten ( 11 mannen en 3 vrouwen) een carcinoom van de restmaag te hebben $(11.9 \%)$.

Van de carcinoom- en niet-carcinoompatiënten worden de gemiddelde leeftijd op het moment van het onderzoek en het gemiddelde tijdsinterval vanaf de operatie met variatie en standaarddeviatie vermeld in Tabel 6.1 .

Tabel 6.1. Patiënten met een BII-maag met klachten, onderzocht meer dan 10 jaar postoperatief, in de periode 1980 tot en met 1982

\begin{tabular}{|c|c|c|c|c|c|}
\hline & \multirow{2}{*}{$\begin{array}{c}\text { aantal } \\
\text { patiénten }\end{array}$} & \multicolumn{2}{|c|}{ geslacht } & \multirow{2}{*}{$\begin{array}{l}\text { germiddelde } \\
\text { leeftijd } \\
\text { (variaticen en SD) }\end{array}$} & \multirow{2}{*}{$\begin{array}{l}\text { gemiddelde } \\
\text { tijdsinterval } \\
\text { (variatie en SD) }\end{array}$} \\
\hline & & man & vrouk & & \\
\hline \multirow{3}{*}{$\begin{array}{l}\text { patiënten } \\
\text { totaal } \\
\text { patiënten met } \\
\text { carcinoom } \\
\text { patiënten zonder } \\
\text { carcinoom }\end{array}$} & 1.18 & 103 & 15 & \multirow{3}{*}{$\begin{array}{l}63.1 \mathrm{jr}(35-90 \mathrm{jr} \\
\text { S.D. } 12.1 \mathrm{jr}) \\
71.11 \mathrm{jr}(54-90 \mathrm{jr} \\
\text { S.D. } 11.1 \mathrm{jr}) \\
\text { 62.0 jr }(35-86 \mathrm{jr} \\
\text { S.D. } 11.8 \mathrm{jr})\end{array}$} & \multirow{3}{*}{$\begin{array}{l}27.1 \mathrm{jr}(11-47 \mathrm{jr} \\
\text { S.D. } 9.0 \mathrm{jr}) \\
\text { 34.2 jr }(23-47 \mathrm{jr} \\
\text { S.D.6.3 jr } \\
\text { 26.1 jr (1.1-44 jr } \\
\text { S.D.8.9 jr) }\end{array}$} \\
\hline & $14(11.9 \%)$ & 11 & 3 & & \\
\hline & $104(88.1 \%)$ & 92 & 12 & & \\
\hline
\end{tabular}

De gegevens van anammese, endoscopisch en histologisch onderzoek worden voor beide groepen patiënten (carcinoom- en niet-carcinoompatiënten) apart gemeld.

\subsection{Gegevens van de anamnese}

De indicaties voor de primaire operatie worden gegeven in Tabel 6.2.

Tabel 6.2. Indicaties voor primaire operatie van de 118 patiënten met cen BII-maag

\begin{tabular}{lccccc}
\hline & $\begin{array}{c}\text { aantal } \\
\text { patiènten }\end{array}$ & UD & UV & UD ofUV & $\begin{array}{c}\text { anderc goedaardige } \\
\text { andounding }\end{array}$ \\
\hline $\begin{array}{l}\text { patiëntenmet } \\
\text { carcinoom }\end{array}$ & 14 & $5(35.7 \%)$ & $4(28.6 \%)$ & $5(35.7 \%)$ & $\cdots$ \\
$\begin{array}{l}\text { patiënten zonder } \\
\text { carcinoom }\end{array}$ & 104 & $45(43.3 \%)$ & $6(5.8 \%)$ & $49(47.1 \%)$ & $4(3.8 \%)$ \\
\hline
\end{tabular}


De vanuit de anammese naat voren komende klachten worden weergegeven in Tabel 6.3. en 6.4.

Tabel 6.3. Klachten van de 104 niet-carcinoompatiënten met een Bll-maag

\begin{tabular}{lcc}
\hline klachten/aantal patienten & ABS & $\%$ \\
\hline eetlust verminderd & 56 & \\
gewicht verminderd & 51 & 53.8 \\
aantal kg. verminderd* & 326 & 49.0 \\
zuurbranden & 31 & 6.4 \\
opboeren & 57 & 29.8 \\
misselijkheid & 42 & 40.8 \\
overgeven & 25 & 24.0 \\
pijn & 50 & 48.1 \\
druk, opgezer gevoel e.d. & 25 & 24.0 \\
\hline
\end{tabular}

" 51 patiënten vermageren in total $326 \mathrm{~kg}$.

$=$ germiddeld $6.4 \mathrm{~kg}$. per vermagerde patiènt

$=$ gemiddeld $3.1 \mathrm{~kg}$. per patiënt

Tabel 6.4. Klachten van de 14 carcinoompatienten met een BII-maag

\begin{tabular}{lcc}
\hline klachten/aantal patiënten & ABS & $\%$ \\
\hline eetlust verminderd & $n=14$ & \\
gewicht verminderd & 9 & 64.3 \\
aantal kg. verminderd* & 13 & 92.9 \\
zurbranden & 99 & 7.6 \\
opboeren & 2 & 14.3 \\
misselijkheid & 8 & 57.1 \\
overgeven & 7 & 50.0 \\
pijn & 5 & 75.7 \\
druk, opgezet gevoel e.d. & 10 & 14.3 \\
\hline
\end{tabular}

* 13 patiënten vermageren in total $99 \mathrm{~kg}$.

$=$ gemiddeld $7.6 \mathrm{~kg}$. per vermagerde patiënt

$=$ gemiddeld $7.1 \mathrm{~kg}$. per patiënt

\subsection{Gegevens van de endoscopie}

De algentene gegevens van endoscopisch onderzoek van de 104 niet-carcinoompatiënten worden vermeld in Tabel 6.5 .

Tabel 6.5.Algemene endoscopiegegevens van de 104 niet-carcinoompatiërnten met een Bll-maag

\begin{tabular}{llcc}
\hline endoscopie gegevens/antal patiërnten & ABS & $\%$ \\
\hline \multirow{2}{*}{ stoma } & normaal & 96 & \\
& plooiconvergentie & 7 & 92.3 \\
stomagastritis & stenose & 1 & 6.7 \\
& geen & 1 & 1.0 \\
corpusgastritis & matig & 33 & 1.0 \\
& duidelijk & 70 & 31.7 \\
hoeveelheid gal & mattig & 31 & 67.3 \\
& duidelijk & 60 & 29.8 \\
& onbekend & 13 & 57.7 \\
& geen & 0 & 12.5 \\
& matig & 20 & 0.0 \\
& veel & 39 & 19.2 \\
\hline
\end{tabular}


De bij endoscopisch onderzoek naar voren gekomen pathologische bevindingen bij do 14 carci noompatiënten kunnen als volgt worden omschreven:

patiènt 1: stoma/praestomaregio dikwallig geinfiltreerd ter hoogte wan de grote curvatuur-voonwandzijde. wijzend op een maligne proces;

patiënt 2: ter hoogte van de voorwandzijde van het stoma een wittig plekje, 1 tn in doorswee, nutuwelijks suspect voor een maligne proces;

patiënt 3: ter hoogte van het stoma spekkige, geinfiltreerde grote curvatuurzijde; ter hoogte van de prestomaregio aan de voorwandzijde naar het lumen bollende weefselpartij; uiceratieve laesie ter hoogte van de kleine curvatuurzijde praestomaregio; een en ander wijzend op een maligne proces;

patiënt 4: ter hoogte van het stoma diffuus geinfiltreerd slijmvlies „zich uitbreidend naar proximaal over een afstand van tenminste $5 \mathrm{~cm}$, wijzend op een maligne proces:

patiënt 5: ter hoogte van het stoma diffuus hobbelig, proliferatief slijmwlies, via de kleine curvatuurzijde zich uitbreidend naar proximaal, wijzend op een maligne proces;

patiënt 6: ter hoogte van het stoma geinfiltreerd weefsel aan de voorwandzijde, met uitbreiding naar de kleine en grote curvatuurzijde; via de voorwandzijde zich uitbreidend naar de regio overgang maag-oesophagus, wijzend op een maligne proces;

patiënt 7: stoma dikwallig geinfiltreerd ter hoogte van de grote curvatuur-voorwandzijde, wijzend op een maligne proces;

patiën 8: ter hoogte van het stoma aan de grote curvatuur-achterwandzijde forse, wittige, geinfiltreerde plooien; kastanjegrote tumor in de proximale maag aan de achterwandzijde, een en ander wijzend op een maligne proces;

patiënt 9: ter hoogte van het stoma nodulair, wittig weefsel; kastanjegrote proliferaties aan de voorwanden achterwandzijde van het corpus, wijzend op een maligne proces;

patiënt 10: ter hoogte van het stoma wallig geinfiltreerde woorwand-kleine curvatuur-achterwandzijde met oppervlakkig ulceratieve laesie, naar proximaal zich uitbreidend over een atstand van $4 \mathrm{~cm}$, wijzend op een maligne proces;

patiënt 11: vernauwd stoma met ietwat stug aandoend weefsel, nief duidelijk maligne van aspect;

patiènt 12: twee tot drie $\mathrm{cm}$ proximaal van het stoma aan de voorwandzijde verzonken wittig weefsel, $3 \mathrm{~cm}$ in doorsnee, suspect voor een maligne proces;

patient 13: halverwege het corpus een kastanjegrote polipoïde tumor aan de kleine curvatuur-achterwandzijde, wijzend op een maligne proces;

patient I4: ter hoogte van de cardia aan de grote curvatuur-achterwandzijde proliferatief-ulceratief weefsel, wijzend op een maligne proces.

$V$ an die 14 carcinoompatiënten bleek het endoscopisch beeld duidelijk op een maligne proces te wijzen in 11 gevallen; eenmaal werd er een suspect beeld in de praestomaregio (patiënt 12) gezien, terwijl tweemaal de afwijkingen niet of nauwelijks geinterpreteerd konden worden als wijzend op of verdacht voor een maligne proces (patiënt 2 en 11). Het carcinoom bleek 11 maall gelocaliseerd ter hoogte van het stoma (waarbij achtmaal met uitbreiding proximaalwaarts); cenmaal in de praestomaregio (patiënt 12), eenmaal ter hoogte van het corpus (patiënt 13) en eenmaal ter hoogte van de cardia (patiënt 14) (zie figuur 6.1).

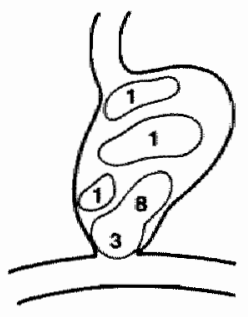

Figuur 6.1.

Locallsatie van de 14 carcinomen in de BHI-maag 
Van de niet-carcinoompatienten werd endoscopisch bij een 79-jarige man, 32 jaar postoperatief, een voor maligniteit suspect beeld gezien: direct praestomaal bevond zich aan de grote curvatuur-achterwandzijde een ietwat verheven, starre indruk makend slijmvliesplateau, met oppervlakkig ulceratieve laesie, $2 \mathrm{~cm}$ in doorsnee. Histologisch bleek geen maligne proces aanwezig, slechts een ulceratieve laesie, een focaal chronische ontsteking en geringe epitheeldysplasie. Een controle-endoscopie ter verkrijging van meer weefselmateriaal voor histologisch onderzoek werd door patiént geweigerd.

De overige bijzondere endoscopische bevindingen bij deze 104 niet-carcinoompatienten worden vermeld in Tabel 6.6.

Tabel 6.6. Bijzondere endoscopische bevindingen bij de 104 niet-carcinoompatiënten met een BII-maag

\begin{tabular}{lcc}
\hline endoscopie gegevens/antal patieñten & $A B S$ & $\%$ \\
\hline forse plooien stoma & 15 & 104 \\
jejunumsijmwlies op rand stoma & 9 & 8.4 \\
wittige plekken stomalcorpus & 10 & 9.6 \\
ulcus pepticum jejuni & 8 & 7.7 \\
ulcus stoma & 2 & 1.9 \\
ulcus praestoma & 1 & 0.9 \\
suspect tilcus praestoma & 1 & 0.9 \\
erosie jejunum & 1 & 0.9 \\
xantelasmata & 8 & 7.7 \\
oesophagitis & 2 & 1.9 \\
\hline
\end{tabular}

\subsection{Gegevens van histologisch onderzoek}

De resultaten wan histologisch onderzoek van de 104 niet-carcinoompatienten worden vermeld in Tabel 6.7. Van één van deze patiënten bleken de biopten van het corpus wan de maag zoekgeraakt te zijn.

Tabel 6.7. Gegevens van histologisch onderzoek van de 104 niet-carcinoom patiënten met een BI』-mag (104 stoma- en 103 corpusbiopsieën)

\begin{tabular}{|c|c|c|c|c|}
\hline \multicolumn{3}{|c|}{ histologische gegevenslatantal patiënten } & \multirow{2}{*}{$\begin{array}{c}A B S \\
n=104 / 103\end{array}$} & \multirow{2}{*}{$\begin{array}{c}\% \\
44.2 \\
\end{array}$} \\
\hline $\mathrm{S}$ & slijmvlieskarakter stoma & antrum & & \\
\hline & & corpus & 52 & 50.0 \\
\hline & & antrum/corpus & 6 & 5.8 \\
\hline \multirow[t]{3}{*}{$\Gamma$} & ontsteking stoma & geen & 10 & 9.6 \\
\hline & & focal & 21 & 20.2 \\
\hline & & diffuus & 73 & 70.2 \\
\hline \multirow[t]{3}{*}{$\mathrm{O}$} & ontsteking stoma & geen & 10 & 9.6 \\
\hline & & licht & 42 & 40.4 \\
\hline & & mattig. & 40 & 38.5 \\
\hline \multirow[t]{3}{*}{ M } & & ernstig & 12 & 11.5 \\
\hline & cysteuze verwijding & & 73 & 70.2 \\
\hline & intestingle metaolasie & & 17 & 16.3 \\
\hline \multirow[t]{2}{*}{ A } & dysplasie & licht & 47 & 45.2 \\
\hline & & matig. & 8 & 7.7 \\
\hline \multirow[t]{3}{*}{$\mathrm{C}$} & ontsteking corpus & geen & 29 & 28.2 \\
\hline & & focaal & 14 & 13.6 \\
\hline & & diffuus & 60 & 58.2 \\
\hline \multirow[t]{3}{*}{$\mathrm{O}$} & ontsteking corpus & geen & 29 & 28.2 \\
\hline & & licht & 28 & 27.2 \\
\hline & & matig & 37 & 35.9 \\
\hline \multirow[t]{3}{*}{$\mathrm{R}$} & & ernstig & 9 & 8.7 \\
\hline & cysteuze verwijding & & 13 & 12.6 \\
\hline & intestinale metaplasie & & 11 & 10.7 \\
\hline \multirow[t]{3}{*}{$\mathrm{P}$} & dysplasie & licht & 9 & 8.7 \\
\hline & & matig & 0 & 0.0 \\
\hline & atrofische gastritis & & 30 & 29.1 \\
\hline \multirow[t]{3}{*}{$\mathrm{U}$} & zoutzourcellen & voldoende & 70 & 68.0 \\
\hline & & verminderd & 19 & 18.4 \\
\hline & & afwezig & 14 & 13.6 \\
\hline $\mathrm{S}$ & & & & \\
\hline
\end{tabular}


Histologisch onderzoek van tijdens de endoscopie genomen biopten toonde een maligne proces aan bij 14 patiënten. Bij 13 patienten bleek dit een carcinoom van het intestinale type te zijn, bij 1 patiënt een carcinoom wan het diffuse type. Zover mogelijk werd het stoma van deze patienten nagekeken op een dysplasie: vierma bl blek het stomabiopt hierop niet te beoordelen (biopsieen toonden alleen carcinoomweefsel), vijfmaal bleek het stoma geen dysplasie te tomen (driemaal stomacarcinoom, tweemaal carcinoom ter hoogte van proximale maag), driemaal bleek een lichte dysplasie aanwezig, eenmaal cen matige dysplasie (bij carcinoom in stoma- en praestomaregio).

Bij 11. patiënten zijn er via onderzoek (histologisch onderzoek van bij endoscopie verk regen matterial en resectiepreparaat, echografisch/CT-scan onderzoek praeoperatief, operatie) argumenten naar woren gekomen pleitend voor het bestaan van een uitgebreid maligne proces. Bij 1 niet geopereerde patiënt is er mogelijk sprake geweest van een tot het stoma beperkt carcinoom met redelijke prognose (patiënt 11), eenmaal werd een gesteelde maligne tumor radicaal verwijderd (patiënt 13), eenmaal bleek een vrij uitgebreid oppervlakkig groeiend carcinoom aanwezig (patient 2), dat overigens niet radicaal werd verwijderd.

$\mathrm{Bij} 1$ patiënt werd een suspect ulcus in de praestomaregio vastgesteld, histologisch onderzoek toonde hier slechts een geringe dysplasie.

Van 10 patiënten met wittige slijmvliesplekken toonde het slijmvlies histologisch achtmaal een duidelijk intestinale metaplasie. Dysplasie van enige betekenis werd bij deze patiënten niet vastgesteld.

Bij 8 niet-carcinoompatiënten (gemiddelde leeftijd 61.4 jaar, gemiddeld interval 28.7 jaar) werd ter hoogte van het stoma een matige dysplasie gezien. Endoscopisch werd bij 1 patiënt een ulcus pepticum jejuni, bij 1 patiënt een lineair ulcus in de praestomaregio vastgesteld. Bij 5 patiënten met een matige dysplasie werd het endoscopisch onderzoek na éen jaar herhaald, waarbij diverse biopsieèn uit de stomaregio werden genomen. Tweemaal werd opnieuw een matige dysplasie vastgesteld, driemaal bleek er geen dysplasie van enige betekenis the bestaan.

\subsection{Ziektegeschiedenis van de carcinoompatiënten}

patiënt 1: man, geboren in 1911; BII-resectie in 1942 in verband met ulcus duodenilijden. Patiënt werd door de huisarts verwezen voor endoscopisch onderzoek in juli 1981 in verband met 7 weken bestaande pijnen ter hoogte van de navel, 3 weken bestaande klachten over zeurende pijnen in epigastrio vooral 's avonds, af en toe overgeven, vermagering van $4 \mathrm{~kg}$. bij goede eetlust. Gastroscopie: vrij kleine Bll-resectiemaag, ter thoogte van restmaag zeer veel gallig secreet; stoma ter hoogte van grote curvatuur-voorwandzijde dikwallig geinfiltreerd, ietwat wittig van kleur; praestomaall aan de voorwandzijde eveneens dikwallig geinfiltreerd slijmvlies, wijzend op een maligne proces. Het corpus van de maag toonde een geinjiceerd slijmvlies, overigens geen bijzonderheden. Bij histologisch onderzoek werd een carcinom van het intestinale type vastgesteld. In verband met de aanwezigheid van levermetast asen (biochemisch en echografisch vastgesteld) werd van operatie afgezien. In augustus 1981 is patiënt overleden.

patiënt 2: vrouw, geboren in 1904; BHI-resectie in 1938 in verband met een ulcus duodenilijden. Patiènte werd in februari 1980 endoscopisch onderzocht in werband met 6 maanden bestaande klachten over verminderde eetlust, gewichtsverlies van $10 \mathrm{~kg}$. , ietwat opboeren en zuurbranden. Gastroscopie: middelgrote BII-resectiemaag, geringe hoeveelheid gal aanwezig; aan de voorwandzijde van het stoma bevond zich een wittig plekje, doorsnee $1 \mathrm{~cm}$, nauwelijks suspect voor een maligne proces; het corpus toonde een matig gevlekt slijmvlies. Histologisch werd een carcinoom van het intestinale type vastgesteld, het corpus wan de maag toonde een sterk verminderd aantal zoutzuurcellen, overigens werden geen afwijkende bevindingen vastgesteld. Bij operatie werd cen partiele maagresectie verricht. Het maagresectiepreparaat toonde macroscopisch licht onregel. matig slijmvlies in het stomagebied, bij histologisch onderzoek bleek multifocaal een superficied groeiend carcinoom van het intestinale type aanwezig, het proximale snijvlak bleek niet vrij van tumor te zijn. Postoperatief hebben er zich geen problemen voorgedaan.

In juni 1982 werd een controle-gastroscopie verricht, waarbij geen afwijkingen van betekenis werden vastgesteld. Histologisch onderzoek toondie een stomaslijmvlies zonder noemenswaardige ontstekingsactiviteit, zonder dysplasie; het corpus toonde een atrofisch slijmvlies. Bij poliklinische controle in februari 1983 bleek patiënte klachtenvrij te zijn.

patiënt 3; vrouw, geboren in 1912; BII-resectie in 1952 in verband met een ulcus ventricult. In 1973 werd in verband met verminderde eetlust, vermagering van $6 \mathrm{~kg}$, pijnen in epigastrio en gevoellens wan misselijkheid een gastroscopie verricht. Endoscopisch en histologisch onderzoek toonde geen 
bifzonderheden. In juni 1981 werd patiënte woor gastroscopie verwezen in verband met enkele maanden bestande klachten over verminderde eethust, vermagering van $3 \mathrm{~kg}$, drukgevoel in de maagstreek en opboeren. Gastroscopie: middelgrote BII resectiemaag, matige hoeveelheid gal aanwexig; ter hoogte wan het stoma spekkig geinfitreerde grote curvatuurzjide; aan voorwandzijde praestomaregio naar lumen bollende weefselpartij; ulceratieve laesie ter hoogte van kleine curvatuurzijde praestomaregio, een en ander wijzend op een maligne proces; corpus licht geinjiceerd sljimvlies. Histologisch onderzoek toonde een carcinoom van het intestinale type. Bij operatie werd een subtotale magresectie met Roux- $Y$-anastomose verricht, tevens vond een cholecystectomie plaats in verband met een galsteenlijden. Metastasen werden niet gezien. Het operatiepreparat toonde ter hoogte van het stoma een wast aanwoelend ulceratief defect $(8 \mathrm{~mm}$ in doorsnee), overigens geen bijzonderheden. Histologisch was een carcinoom van het intestinale lype aanwezig, dat door de gehele wand heengroeide; het stoma toonde elders een duidelijk chronische ontsteking, intestinale metaplasie en lichte dysplasie; het corpus van de maag toonde een duidelijk chronische ontsteking, eveneens intestinale metaplasie, lichte dysplasie en locale atrofie. Postoperatief hebben er zich geen problemen voorgedaan. Een gastroscopie d.d. maart 1982 toonde een status na subtotale maagresectie zonder bijzonderheden. In februari 1983 was patiënte nog in leven, verkeerde in redelijk algemene conditie.

patiënt 4: man, geboren in 1926; Bll-resectie in 1957 in verband met een ulcus duodeni. In verband met een ulcus pepticum jejuni werd in 1962 een wagotomie verricht. In november 1980 werd patient endoscopisch onderzocht in werband met 8 wekem bestaande klachten over een verminderde eetlust, vermagering van $4 \mathrm{~kg}$, diffuse pijnen ter hoogte van de onderbuik. Gastroscopie: middeigrote Bll-resectiemaag, geringe hoeveelheid gal aanwezig; ter hoogte van stoma diffuus geinfiltreerd, witrig slijmvlies, zich uitbreidend naar proximaal over een afstand van tenminste $5 \mathrm{~cm}$, wijzend op een maligne proces; het corpus van de maag toonde ietwat forse plooien, overigens geen bijzonderheden. Histologisch onderzoek toonde een carcinoom van het intestinale type. Bij operatie bleek hef carcinoom ruim in de omgeving door te groeien, inoperabel te zijn. In maart 1981 volgde een blokkade van de plexus coeliacus in verband met op analgetica niet reagerende pijnen. In augustus 1981 vond een opname in thet ziekenhuis plaats in verband met 6 maanden bestaande diarree, duidelijk verminderde eetlust, progressief gewichtsverlies. In september 1981 is patient overleden.

patiènt 5: man, geboren in 1910; BLI-resectie in 1944 in werband met een ulcuslijden (ulcus duodeni?, ulcus ventriculi?). In 1962 werd een cholecystectomie verricht in verband met een cholecystitis acuta. In maart 1980 werd pattënt endoscopisch gezien in verband met 6 maanden bestaande klachten over verminderde eetlust, vermagering van $8 \mathrm{~kg}$, pijnen in epigastrio. Gastroscopie: middelgrote Bll-resectiemaag, geringe hoeveelheid gal ananezig; ter hoogte van het stoma diffuus hobbelig, proliferatief slijmvlies, via kleine curvatuurzijde zich uitbreidend naar proximaal, wijzend op een maligne proces; ter hoogte wan het corpus licht geinjiceerd sijimvlies. Histologisch onderzoek wees op het bestaan van een carcinoom van het intestinale type. Bij operatie bleek er ter hoogte van de maagstomp een vuistgrote tumor aanwezig, er bestond ingroei in het colon transversum, in de directe omgeving waren metastasen zichtbaar; cen gastro-enterostomie werd verricht. $\mathrm{Pa}$ tiënt is in september 1981 icterisch overleden.

patiënt 6: vrouw, geboren in 1897; Bll-resectie in 1945 in verband met een ulcuslijden (ullcus duodeni?, alcus ventriculi?). In augustus 1980 werd een gastroscopie verricht in verband met enkele weken bestande klachten over recidiverend braken en bovenbuikspijnen. Gastroscopie: middelgrote Bll-resectiemaag, veell retentiemateriaal aanwezig; ter hoogte van stoma geinfiltreerd weefsel aan voorwandzijde, met untbreiding naar kleine-en grote curvatuurzijde, via voorwandzijde zich witbreidend naar de oesophagus, wijzend op een maligne proces. Histologisch onderzoek wees op het bestaan van een carcinoom van het intestinale type. Operatie vond niet plaats gezien de leeftijd van patiënte en uitgebreidheid van het carcinoom. Patiënte is overleden in september 1980 .

patiëni 7: man, geboren in 1900; BH-resectie in 1946 in verband met ulcuslijden (ulcus duodeni", ulcus ventriculi?). In april 1981 werd een gastroscopie verricht in verband met 8 maanden bestaande klachten over een wermagering wan $10 \mathrm{~kg}$ bij redelijke eetlust, drukgevoel in de maagstreek. Een duidelijke ijzergebreksanaenic bleek aanwezig te zijn. Gastroscopie: middelgrote Bll-resectiemaag, matige hoeveelheid gal aanwezig; ter hoogte van stoma aan de grote curvatuur-voorwandzijde dikwallig geinfiltree rd slijmvlies, wijzend op een maligne proces; corpus zonder bijzonderheden. Histologisch onderzoek wees op het bestaarn van een carcinoom van het intestinale type. Gezien de leeftijd wan patiönt werd wan operatie afgezien. In verband met een recidiverende anaemie waren herhaalde malen bloedtransfusies noodzakelijk. In november 1980 werd opnieuw een gastroscopie vericht in werband met een bloeding: stoma diffuus spekkig geinfiltreerd, uitbreiding oraalwaarts over een afstand van tenminste 3 a $4 \mathrm{~cm}$, via voorwandzijde uitbreiding tot aan de oesophagus. In november 1982 is patiënt overleden. 
patient 8: man, geboren in 1926; BII-resecte in 1948 in werband met ed ulcus duodenilijen. In april 1980 werd een gastroscopie verricht in werband met bestande klachten over wetmagering wan $4 \mathrm{~kg}$. bij goede eetlust, pijnen in epigastrio, opboeren en gevoetens van misselijkheid. Gastroscopie: middelgrote BII resectiemaag, matig veel gal aanwezig; ler hoogte van het stoma aan de grote curvatuur-achterwandzijde forse, wittige, geinfiltreerde plooien; kastanjegrote tumor proximate matag aan de achterwandzijde, een en ander wijzend op een maligne proces; corpus matig geinjicent slijmvlies. Bij histologisch onderzoek werd een catcinoom van het diffuse type vastgesteld. Bij operatie bleek een maligne proces anwezig, vrijwel de gehele masg innemend, met doorgroei in de directe omgeving, als inoperabel te kwalificenen. In augustus 1980 is patient overleden.

patiënt 9: man, geboren in 1897; BII-resectia in 1948 in verband met een ulcus ventriculi. In jumil 1980 werd een gastroscopie verricht in verband met 6 weken bestaande klachten over vernunderde eet lust, gewichtsverlies van $12 \mathrm{~kg}$, opboeren, misselijkheid, overgeven en laag retrostemal blijven steken van voedsel. Gastroscopie: middelgrote BII-resectiemaag, geringe hoeveelheid gal aanwezig; ter hoogte wan het stoma nodulair, wittig weefsel; kastanjegrote proliferaties atn voorwanden achterwandzijde van het corpus, wijzend op een maligne proces; distale oesophagus geen bijzonderheden. Histologisch onderzaek wees op het bestaan van een carcinoom van het intestinale type. Op aandringen van de familie werd operatie verricht: er bleek een groot carcinoorn tot in de oesophagus aanwezig, als inoperabel te beschowwen, een peritonitis carcinomatosa was anwe. zig. Postoperatief is patiënt snel achteruitgegaan, exitus volgde ongeveer 14 dagen na de operatie.

patiènt 10: man, geboren in 1917; BH-resectie in 1946 in verband met een ulcus duodenilijdan. In 1973 werd een gastrosicopie verricht in verband met 4 jaar bestaande klachten over verminderde eetlust, geringe vermagering, af en toe opboeren, overgeven en drukgevoel in epigastrio. Endoscopisch noch histologisch werden afwijkingen van betekenis vastgesteld. In november 1981 werd een gastroscople verricht in verband met ongeveer 1 jaar bestaande klachten over bandvormige pijnen ter hoogte van de bovenbuik, zuurbranden, opboeren en gevoelens van misselijkheid. Gastroscopie: middelgrote BL-resectiema. veel gal aanwezig; ter hoogte van het stoma wallig geinfitreerd slijmvlies aan de voorwand-kleine curvatuur-achterwandzijde met oppervlakigig ulceratieve laesie, naar proximaal zich uitbreidend over een afstand van $4 \mathrm{~cm}$, wijzend op een maligne proces; matig geinjiceerd slijmvlies ter hoogte van het corpus van de restmakg. Histologisch onderzoek wees op een carcinoom van het intestinale type. Operatie vond niet plaats op advies van behandelend internist. Patiënt was nog in leven in februari 1983 , in en slechte allgemene conditie.

patiënt 11: man, geboren in 1890; BII-resectie in 1933 in verband met een ulcus ventriculi. In ok 10 ober 1980 werd een gastroscopie verricht in verband met 1 jaar bestaande klachten over verminderde cetlust, vermagering van $9 \mathrm{~kg}$., pijnen in epigastrio, opboeren en misselijkheid. Gastroscopie: middelgrote BII-resectiemaag, veel gal ter hoogte van restmaag; vernauwd stoma, ietwat stug aandoend weefsel, niet duidelijk maligne van aspect; rood geinjiceerd stomit- en corpusslijmvlies. Histologisch bleek een carcinoom van het intestinale type aanwezig te zijn. Gezien de leeftijd van patient werd van operatie afgezien. In september 1981 werd eem onderbeenamputatie rechts ver richt in verband met een gangreen van de rechtervoet. Sedert operatie bleek patient in gewicht 10 $\mathrm{kg}$ verminderd te zijn. In februari 1983 was patient nog in leven, verkeende in een zeer matige al gemene conditie.

patient 12: man, geboren in 1906; BLI-resectie in 1945 in verband met een ulcuslijden (ulcus duodeni", ulcus ventriculi?). In mat 1980 werd een gastroscopie verricht in verband met enkele maanden bestaande klachten over gewichtsvermindering van $15 \mathrm{~kg}$. bij normale eatust, drukgevoel in de maagstreek. Gastroscopie: vrij kleine BII-resectiemaag. matig weel gal ter hoogte van de restmaag, fraai stona met rood geinjiceerd siljmwlies; 2 tot $3 \mathrm{~cm}$ proximaal van stoma aan voorwandzijde verzonken wittig weefsel, $3 \mathrm{~cm}$ in doorsnee, suspect voor een maligne proces; courpus matig geinjiceerd, hier en daar wit vlekkerig slijmwlies. Bij histologisch onderzoek werd een cincinoom van het intestimale type vastgesteld. War er een coin-llesion ter hoogte van de linker long annwezig was (sputum suspect voor maligne cellen) werd afgezien van operatie. In april 1981 is patiënt cachectisch overleden.

patiènt 13: man, geboren in 1910; BШl-resectie in 1948 in verband met nalcuslijden (ulcus duodeni?, ulcus ventriculi?). In julli 1980 werd een gastrosoopie verricht in verband met 6 manden bestatande klachten over verminderde eetlust, gewichtsverlies wan $8 \mathrm{~kg}$, pijn in epigastrio links, overgeven en dergelijke. Een ijzergebreksanaemie bleek an wezig te zijn. Gastroscopie: middelgrote BII-resectiemaag, geringe hoeveelheid gal danwezig; halverwege het corpus van de maag aan de kleine curvatuur-achterwandzijde kastanjegrote, hobbelige tumor, wijzend op een maligne proces; corpus owerigens geem bijzonderheden. Histologisch onderzoelk wees op het bestaan wan een carci noom van het intestinale type. Bij operatie bleek een gesteelde tumor anawezig (doorsnee stecl 2 $\mathrm{cm}$, doorsnee tumor $4 \mathrm{~cm}$ ), die via een wigexcisie werd verwijderd. Bij histologisch onderzoek bleek een hoog gedifferentieerd adenopapillair carcinoom aanwezig met aanduiding van invasic: 
ve groei, de resectievlakken bleken vrij te zijn. Postoperatief hebben er zich geen bijzonderheden woorgedaan. In fobruan 1983 was patiën nog in levea, in een redelijk algemene conditie.

patient 14: man, geboren in 1923; BII-resectie in 1955 in verband met een ulcus ventriculi. In 1957 werd een vagotomie verricht in verband met een ulcus pepticum jejuni. In 1970 werd een gastroscopie verricht in verband met enig gewichtswerlies en pijnen in epigastrio, Bij endoscopisch onderzoek werd het beeld van een matige stoma en corpusgastritis gezien, histologisch onderzoek toonde intestimale metaplasie ter hoogte van het stoma, overigens geen bijzonderheden. In december 1980 werd een gastrascopie verricht in verband met 4 maanden bestaande klachten over pijnen in epigastrio, uitstralenid naar thoracal, gewichtsverlies van $4 \mathrm{~kg}$, regelmatig opboeren. Gastroscopie: middlelgrote BIL-resectiemag, veel gal alanwezig; fraai stoma met rood geinjiceerd slijnvlies en millimetergrote witte plekjes, matig geinjiceerd maagslijmvlies met galbrokken, ter hoogte van cardia aan grote curwatuur-achterwandzijde proliferatief-ulceratief weefsel, wijzend op maligne proces. Histologisch onderzoek wees op een carcinoom van het intestinalle type. Waar echografisch het beeld wan levermetastasen aanwezig bleek, een CT-scan wees op het bestaan van een grote tumormassa in de cardiaregio van de maag met doorgroei naar pancreasstaart en milthilus, werd van operatie afgezien. Therapie met cytostatica voigde, patient is cachectisch overleden in maat 1981 .

\subsection{Samenvatting van de onderzoekgegevens}

Uit dit onderzoek komen de volgende gegevens naar vorem:

- bij 118 patiènten met maagklachten, endoscopisch en histologisch onderzocht in de periode 1980 tot en met 1982, meer dan 10 jaar na een BII-resectie, werd bij 14 patienten (gemiddelde leeftijd 71.1 jaar, gemiddeld interval 34.2 jaar) histologisch een carcinoom vastgesteld (13 maal van het intestinale type, eenmaal van het diffuse type);

- het klachtenpatroon van de carcinoompatienten verschilde niet significant van dat van de nietcarcinoompatiënten; bij de carcinoompatiënten bleken meer klachten in combinatie aanwezig; de carcinoompatiënt vermagerde gerniddeld $7.1 \mathrm{~kg}$, de niet-carcinoompatiënt gemidcleild 3.1 $\mathrm{kg}$;

- bij de 14 carcinoompatiënten bleek ter hoogte van het stoma een matige dysplasie slechts tweemaal aanwezig te zijn, waarbij aangetekend dat het stoma hierop bij 4 patiënten niet te beoordelen was;

- slechts bij 1 van de 14 carcinoompatiënten werd de maligne tumor radicaal verwijderd (gesteelde tumor); theoretisch zou dit mogelijk bij 3 patiënten nog het geval geweest kunnen zijn; bij de overige patiënten bleek een radicale operatie niet mogelijk door uitgebreidheid van het proces, doorgroei in de directe omgeving of metastasen op afstand;

- bij 10 niet-carcinoompatiènten werden bij endoscopie wittige slijmvliesplek ken gezien, bij 8 patiënten bleek histologisch een duidelijke intestinale metaplasie aanwezig, een matige dysplasie werd bij deze patiènten ter hoogte van het stoma niet vastgesteid;

- bij 8 niet-carcinoompatiënten werd ter hoogte van het stoma histologisch een matige dysplasie gezien, bij 3 van de 5 geherendoscopicerde patiènten kon dit fenomeen niet opnieuw worden vastgesteld;

- zeer frequent werd histologisch ter hoogte van het stoma een cysteuze verwijding van cle klierbuizen gezien $(70.2 \%)$, hetgeen opgevat kan worden als een kenmerkend afwijkende bevinding van het stomaslijmvlies;

- een lichte dysplasie van het stomaslijmvlies was een zeer frequente bevinding bij histologisch onderzoek. 


\section{Hoofdstuk 7}

\section{Endoscopisch en histologisch onderzoek van BII-ma- gen, meer dan 10 jaar postoperatief, bij patiënten zon- der klachten, in de periode 1980 tot en met 1982}

In de periode 1980 tot en met 1982 werden 138 symptoomloze patienten, meer dan 10 jaar na een BII-resectie geendoscopieerd in het kader van een onderzoek op een stompcarcinoom. Van de 138 patiënten bleken 5 patiënten ( 5 mannen) een stompcarcinoom te hebben.

Van de carcinoom- en niet-carcinoompatiënten worden de gemiddelde leeftijd op het moment van het onderzoek en het gemiddelde tijdsinterval vanaf de operatie met variatie en standaarddeviatie vermeld in Tabel 7.1 .

Tabel 7.1. Patiènten met een BII-maag zonder klachten ${ }_{*}$ onderzocht meer dan 10 jaar postoperatief, in de periode 1980 tot en met 1982

\begin{tabular}{|c|c|c|c|c|c|}
\hline & \multirow{2}{*}{$\begin{array}{l}\text { aantal } \\
\text { patiènten }\end{array}$} & \multicolumn{2}{|c|}{ geslacht } & \multirow{2}{*}{$\begin{array}{l}\text { gemiddelde } \\
\text { leeftijd } \\
\text { (variatie en SD) }\end{array}$} & \multirow{2}{*}{$\begin{array}{l}\text { geniddelde } \\
\text { tijdsinterval } \\
\text { (variatie en } S D \text { ) }\end{array}$} \\
\hline & & man & vroun & & \\
\hline patiënten totaal & 138 & 127 & 11 & \multirow{3}{*}{$\begin{array}{l}62.0 \mathrm{jr}(35-86 \mathrm{jr} \\
\text { S.D. } 11.0 \mathrm{jr}) \\
65.0 \mathrm{jr}(64-66 \mathrm{jr} \\
\text { S.D.0.8j } \\
\text { 6.9 jr }(35-86 \mathrm{jr} \\
\text { S.D. } 11.2 \mathrm{jr})\end{array}$} & \multirow{3}{*}{$\begin{array}{l}25.6 \mathrm{jr}(11.43 \mathrm{jr} \\
\text { S.D. } 8.7 \mathrm{jr}) \\
34.4 \mathrm{jr}(30-40 \mathrm{jr} \\
\text { S.D. } 4.4 \mathrm{jr}) \\
25.3 \mathrm{jr}(11 \mathrm{l}-43 \mathrm{jr} \\
\text { S.D.8.7 jr) }\end{array}$} \\
\hline $\begin{array}{l}\text { patiènten met } \\
\text { carcinoom }\end{array}$ & $5(3.6 \%)$ & 5 & -- & & \\
\hline $\begin{array}{l}\text { patiënten zonder } \\
\text { carcinoom }\end{array}$ & $133(96.4 \%)$ & 122 & 11 & & \\
\hline
\end{tabular}

\subsection{Gegevens van de anamnese}

De indicaties voor de primaire operatie worden in Tabel 7.2. gegeven.

Tabel 7.2. Indicaties voor primaire operatie van de 138 patiënten met een BII-maag

\begin{tabular}{lccccc}
\hline & $\begin{array}{l}\text { aantal } \\
\text { patiënten }\end{array}$ & UD & UV & UDof UV & $\begin{array}{l}\text { andere goedardige } \\
\text { aandoening }\end{array}$ \\
\hline $\begin{array}{l}\text { patiënten met } \\
\text { carcinoom }\end{array}$ & 5 & $3(60 \%)$ & $1(20 \%)$ & $1(20 \%)$ & $\ldots$ \\
$\begin{array}{l}\text { patiënten zonder } \\
\text { carcinoom }\end{array}$ & 133 & $70(52.7 \%)$ & $4(3.0 \%)$ & $49(36.8 \%)$ & $10(7.5 \%)$ \\
\hline
\end{tabular}

\subsection{Gegevens van de endoscopie}

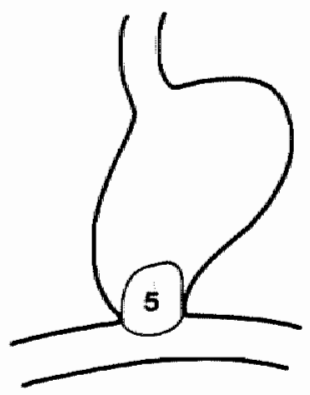

Figuur 7.1.

Localisatie van de 5 carcinomen in de Bll-maag 
Endoscopisch onderzoek van de 5 patiënten, bij wie histologisch een intramucosaal carcinoom bleck te bestaan (zie figuur 7.1), toonde in geen van deze gevallen afwijkingen, duidelijk wijzend in de richting van een maligne proces. Viermaal werden minimale slijmvliesafwijkingen vastgesteld, enmaal bleck een ulceratieve laesie aanwezig, op zich niet maligne ogend, echter suspect gezuen de klinische situatie (interval vanaf operatie 37 jaar, ulceratieve laesie bij afwezigheid van klachten).

De endoscopische bevindingen bij deze 5 patiënten kumnen als volgt worden omschreven:

patient 1: millimetergrote wittige plekjes op de stomarand (niet typisch voor jejunumweefsel, intestinale metaplasie of xantelasmata), stomarand ietwat verhoogd kwetsbaar ter hoogte van de achterwandzijde; geen duidelijke verdenking op een stompcarcinoom;

patiënt 2: ter hoogte van het stoma aan de achterwandzijde een minimaal wittig plekje, wiet verdacht voor een maligne proces;

patient 3: ter hoogte van het stoma aan de kleine curwatuur-achterwandzijde ietwat verhoogd kwetsbaar, erosief slijmvlies; micro-poliepjes ter hoogte van de achterwandzijde, een en ander nauwelijks suspect voor een stornpcarcinoom;

patiënt 4: ter hoogte van helt stoma aan de grote curvattuur-voorwandzijde een oppervlakkig ulceratief plekje. $3 / 4 \mathrm{~cm}$ in doorsnee; ter hoogte van de voorwandzijde van het stoma een langwerpig ulceratieve laesie, $1,5 \times 0,5 \mathrm{~cm}$, niet maligne van aspect;

patiènt 5: ter hoogte van de praestomaregio aan de voorwandzijde een plooiconvergentie, plooien ietwat onregelmatig, enkele haemorragische plekjes, een en ander nauwelijks suspect voor een maligne proces.

Van de 133 niet-carcinoompatiënten worden de algemene gegevens van endoscopisch onderzoek vermeld in Tabel 7.3 .

Tabel 7.3. Algemene endoscopiegegevens van de 133 niet-carcinoompatiènten met een BII-maag

\begin{tabular}{llcc}
\hline \multirow{2}{*}{ endoscopie gegevens/aantal patienten } & ABS & \% \\
& & 133 & \\
\hline stoma & normaal & 119 & 89.5 \\
& ploojconvergentie & 12 & 9.0 \\
stenose & 2 & 1.5 \\
stomagastritis & geen & 0 & 0.0 \\
& matig & 43 & 32.3 \\
& duidelijk & 90 & 67.7 \\
corpusgastritis & geen & 15 & 11.3 \\
& matig & 99 & 74.4 \\
& duidelijk & 19 & 14.3 \\
hoeveellheid gal & onbekend & 0 & 0.0 \\
& geen & 33 & 24.8 \\
& matig & 50 & 37.6 \\
& veel & 50 & 37.6 \\
\hline
\end{tabular}

Viemaal werden er bij endoscopisch onderzoek afwijkende slijmvliesbeelden gezien, niet apert maligne van aspect, doch dusdanig afwijkend van aard, dat rekening diende te worden gehouden met een maligne ontaarding. De ziektegeschiedenissen van deze patiënten zijn toegevoegd aan de lijst ziektegeschiedenissen van de carcinoompatiënten.

De bij endoscopie wastgesteld afwijkende beelden kunnen als volgt worden omschreven:

patiënt 6: ter hoogte van het stoma aan de voorwand-kleine curvatuurzijde een gebiedje van $2 \times 2 \mathrm{~cm}$ van fijn brokkelig wit weefsel (PA: uitgebreid intestinale metaplasie met matige dysplasie), matig suspect voor een maligne proces;

patiënt 7: ter hoogte van het stoma een de kleine curvatuurzijde stug weefsel met diverse wittige plekjes (PA: intestinale metaplasie en lichte dysplasie), enigszins suspect voor een maligne proces; 
patiènt 8: $\pm 4 \mathrm{~cm}$ praestomaal aan de voorwandzijde een licht verheven wittig slijmvliesgebiedje, $1,5 \times 1,0$ $\mathrm{cm}$, adenomateus van aspect (PA: uitgebreid duidelijk adenomateus dysplastische veranderingen), enigszins suspect voor een maligne proces;

patiënt 9: ter hoogte van de voorwandzijde van het corpus 2 slijnvliesflappen, $1,5 \times 0,75 \mathrm{~cm}$, aarbei-achtig. van aspect (PA: sterk chronische ontsteking, plaatselijk adenomatewze veranderingen met matige dysplasie), niet duidelijk maligne van aspect.

De bijzondere endoscopische bevindingen van de 133 niet-carcinoompatiènten worden vermeld in Tabel 7.4.

Tabel 7.4. Bijzondere endoscopüsche bevindingen bij de 133 niet-carcinoompatiènten met een Bll-maag

endoscopie gegevens/aantal patiënten

ABS

$\%$

$n=133$

$\begin{array}{lrr}\text { forse plooien stoma } & 9 & 6.8 \\ \text { jejunumslijmvlies op rand stoma } & 8 & 6.0 \\ \text { wittige plekken stoma/corpus } & 12 & 9.1 \\ \text { ulcus pepticum jejuni } & 2 & 1.5 \\ \text { ulcus praestoma } & 1 & 0.7 \\ \text { xantclasmata } & 16 & 12.0 \\ \text { adenomateus weefsel } & 2 & 1.5 \\ \text { kwetsbaar slijmvlies stoma } & 3 & 2.3 \\ \text { poliepen } & 4 & 3.0 \\ \text { oesophagitis } & 1 & 0.7\end{array}$

\subsection{Gegevens van histologisch onderzoek}

Histologisch onderzoek van bij endoscopie genomen biopten wees op het bestaan van intramucosale carcinomen bij 5 patiënten uit deze symptoomloze groep met een BII-resectiemaag meer dan 10 jaar postoperatief. De resectiepreparaten van deze patiënten toonden carcinomen, beperkt tot de mucosa, zonder verdere invasie van de maagwand of lymfkliermetastasen. Vier carcinomen bleken van het intestinale type te $z i j n, 1$ carcinoom van het diffuse type. Drie carcinomen bleken multifocaal van origine te zijn, waarbij het carcinoom van het diffuse type. De carcinomen waren allen gesitueerd in de directe omgeving van het stoma.

De overige histologische bevindingen van deze 5 patiënten en van de groep niet-carcinoompatiënten worden gegeven in Tabel 7.5, en 7.6.

Histologisch onderzoek van het endoscopisch afwijkende slijmvlies van de patiënten $6,7,8$ en 9 toonde geen maligne afwijkingen, wel uitgebreid intestinale metaplasie met matige dysplasie bij patiënt 6 , intestinale metaplasie en lichte dysplasie bij patiënt 7 , uitgebreid adenonateus dysplastische afwijkingen bij patiënt 8 en plaatselijk adenomateuze veranderingen met matige dysplasie bij patient 9 .

Histologisch onderzoek van de 12 wittige slijmwliesplekken toonde 10 maal een intestinale metaplasie (achtmaal ter hoogte van het stoma, tweemaal ter hoogte van het corpus van de maag). ging eenmaal gepaard met een matige dysplasie (ter hoogte van het stoma). De 4 poliepjes, verwijderd met de diathermiesnaar, bleken hyperplastisch van aard te zijn, eenmaal werd in combinatie met een poliep een matige dysplasie wan het stomaslijmvlies aangetoond. Onderzoek van het verhoogd kwetsbare slijmvlies toonde enmal een matige dysplasie.

Bij histologisch onderzoek van het stomaslijmvlies werd negenmaal een matige dysplasie vastgesteld. Bij endoscopisch onderzoek van deze patiënten (gemiddelde leeftijd 63.4 jaar, gemiddeld interval 31.0 jaar) werden bij 4 patiënten geen bijzonderheden vastgesteld. Bij de overige 5 patiënten werden driemaal xantelasmata in de stomaregio gezien, eenmaal wittig slijmvlies ter hoogte van het stoma, eenmaal een klein poliepje ter hoogte van het stoma, tweemaal adenomateus slijmvlies ter hoogte van het praestoma en het corpus van de restmaag.

Bij 6 patiënten met een matige dysplasie werd het endoscopisch onderzoek herhaald na cen jaar, waarbij diverse biopten genomen werden uit de stomaregio. Driemaal werd opnieuw een matige dysplasie van het stomaslijmvlies vastgesteld, tweemaal bleek er sprake te zijn van een lichte dysplasie, terwijl zesmaal herhaald histologisch onderzoek bij 1 patiënt (adenomateus weefsel ter hoogte van het corpus van de restmaag) afwisselend een lichte tot matige dysplasie toonde. 
Tabel 7.5. Gegevens van histologisch onderzoek van de 5 carcinoompatiènten met een BII-maag

\begin{tabular}{|c|c|c|c|c|}
\hline \multicolumn{3}{|c|}{ Bistologische gegevensiatantal patiënten } & \multirow{3}{*}{$\begin{array}{c}A B S \\
n=5 \\
3 \\
1\end{array}$} & \multirow{2}{*}{$\begin{array}{l}\% \\
60.0\end{array}$} \\
\hline$\$$ & slijmvlieskarakter stoma & antrum & & \\
\hline & & corpuss & & 20.0 \\
\hline & & antrum/corpus & 1 & 20.0 \\
\hline \multirow[t]{3}{*}{$\mathrm{T}$} & ontsteking stoma & geen & 1 & 20.0 \\
\hline & & focaal & 1 & 20.0 \\
\hline & & diffurus & 3 & 60.0 \\
\hline \multirow[t]{3}{*}{0} & ontsteking stoma & geen & 1 & 20.0 \\
\hline & & licht: & 1 & 20.0 \\
\hline & & matig & 3 & 60.0 \\
\hline \multirow[t]{3}{*}{ M } & & emstig & 0 & 0.0 \\
\hline & cysteuze verwijding & & 5 & 100.0 \\
\hline & intestinale metaplasic & & 1 & 20.0 \\
\hline \multirow{2}{*}{ A } & dysplasic & licht & 0 & 0.0 \\
\hline & & matig & 4 & 80.0 \\
\hline \multirow[t]{3}{*}{$\overline{\mathrm{C}}$} & onisteking corpus & geen & 2 & 40.0 \\
\hline & & focant & 2 & 40.0 \\
\hline & & diffuus & 1 & 20.0 \\
\hline \multirow[t]{3}{*}{0} & ontsteking corpus & geen & 2 & 40.0 \\
\hline & & licht & 1 & 20.0 \\
\hline & & matig & 2 & 40.0 \\
\hline \multirow[t]{3}{*}{ R } & & ernstig & 0 & 0.0 \\
\hline & cysteuze verwijding & & 1 & 20.0 \\
\hline & intestinale metaplasie & & 3 & 60.0 \\
\hline \multirow[t]{3}{*}{$\mathrm{P}$} & dysplasie & licht & 1 & 20.0 \\
\hline & & matigg & i & 20.0 \\
\hline & atrofische gastritis & & 2 & 40,0 \\
\hline \multirow[t]{4}{*}{$\mathbb{U}$} & zoutzunrcellen & volidoende & 3 & 60.0 \\
\hline & & verminderd & 0 & 0.0 \\
\hline & & afwezig & 2 & 40.0 \\
\hline & & & & \\
\hline
\end{tabular}

Tabel 7.6. Gegevens van histologisch onderzoek van de 133 niet-carcinoompatiènten met een BII-maag

\begin{tabular}{|c|c|c|c|c|}
\hline \multicolumn{3}{|c|}{ hisfologische gegevens/aantal patiënten } & \multirow{2}{*}{$\begin{array}{c}A B S \\
n=133 \\
63\end{array}$} & \multirow{2}{*}{$\begin{array}{r}\% \\
47.4\end{array}$} \\
\hline$s$ & slijmulieskarakter stoma & antrum & & \\
\hline & & corpus & 65 & 489 \\
\hline & & antrum/corpus & 5 & 3.7 \\
\hline \multirow[t]{3}{*}{$\mathrm{T}$} & ontsteking stoma & geen & 24 & 180 \\
\hline & & focaal & 28 & 21.1 \\
\hline & & diffuus & 81 & 60.9 \\
\hline \multirow[t]{3}{*}{0} & ontsteking stoma & geen & 24 & 18.0 \\
\hline & & Fiche & 56 & 42.2 \\
\hline & & matig & 45 & 33.8 \\
\hline \multirow[t]{3}{*}{ M } & & ernstig & 8 & 6.0 \\
\hline & cysteuze verwijding & & 99 & 74.4 \\
\hline & intestinale me taplasie & & 29 & 21.8 \\
\hline \multirow[t]{2}{*}{ A } & dysplasie & licht & 71 & 53.4 \\
\hline & & matig & 9 & 6.8 \\
\hline \multirow[t]{3}{*}{$\bar{c}$} & ontsteking corpus & geen & 29 & 21.8 \\
\hline & & focalal & 35 & 26.3 \\
\hline & & diffuus & 69 & 51.9 \\
\hline \multirow[t]{3}{*}{0} & ontsteking corpus & geen & 29 & 21.8 \\
\hline & & licht & 37 & 27.8 \\
\hline & & matig & 51 & 38.3 \\
\hline \multirow[t]{3}{*}{$\mathbf{R}$} & & ernstig & 16 & 12.1 \\
\hline & cysteuze verwijding & & 14 & 10.5 \\
\hline & intestinale metaplasie & & 31 & 23.3 \\
\hline \multirow[t]{3}{*}{ P } & dysplasie & licht & 8 & 6.0 \\
\hline & & matig & 0 & 0.0 \\
\hline & atrofische gastrixis & & 49 & 36.8 \\
\hline \multirow[t]{3}{*}{ U } & zoutzuurcellen & voldoende & 77 & 57.9 \\
\hline & & verminderc: & 39 & 29.3 \\
\hline & & afwezig & 17 & 12.8 \\
\hline
\end{tabular}




\subsubsection{Ziektegeschiedenis van de carcinoompatiënten}

patiènt 1: man, geboren in 1916; BII-resectie in 1942 in verband met een ulcus duodent. Bekend met chronische bronchitis en silicosis pulmonum sedert 1960. In 1972 gastroscopie in verband nuet ongeveer 1 jaar bestaan atypische magkklachten (ietwat zuurbranden, enkele maal overgeven, drukgevoel in epigastrio). Gastroscopie: wijd stoma met duidalijk oedemateus en rood geinjiceerd. slijmvlies; corpusslijmvlies in mindere mate geinjiceerd, mogelijk licht atrofisch. Histologisch onderzoek stornabiopt: slijmvlies van corpustype, matige hoeveelheid tuurvormende cellen, cysteuze werwijding van klierbuizen, gering rondkernig infiltrat lamina propria, geringe dysplasie. Histologisch onderzoek corpusbiopt: nauwelijks infiltraat lamina propria, cysteuze verwijding klierbuizen, mucosa-atrofie, weinig zuurvormende cellen, intestinale metaplasie, geen dysplasie. Symptomatische therapie volgde, waarna klachten verdwenen. In juni 1982 door huisaris werwezen voor endoscopie in het kader van een onderzoek op een stompcarcinoom. Gastroscopie: middelgrote BII-resectiernaag, ter hoogte van restmaag veel gal aanwezig; stomarand matig oedemateus en rood geinjiceerd, op stomarand millimetergrote wittige plekjes, die niet typisch waren voor jejunumweefsel, intestinale metaplasie of xantelasmata; stomarand ietwat verhoogd kwest baar ter hoogte van achterwandzijde, geen duidelijke verdenking op stompcarcinoom; corpusslijmvlies gevlekt met duidelijk zichtbare vattekening, wijzend op atrofie. Histologie stoma biopt: slijmwlies van antrumtype, enkele licht cysteus verwijde klierbuisstructuren; intramucosaal carcinoom ter hoogte van de achterwand, lichte tot matige dysplasie elders. Histologisch onder. zoek corpusbiopt: uitgebreide enigszins atypische metaplasie, weinig ontstekingsactiviteit in lamina propria, sterk gereduceerd aantal zoutzuurcellen. Na overleg met de longarts volgde operatie: subtotale maagresectie met Roux-Y-anastomose. Het maagresectiepreparaat toonde ter hoogte van het stomagebied enkele haemorragische plekken, overigens geen bijzonderheden. Histologisch onderzoek toonde een intramucosaal carcinoom ter hoogte van de achterwand, van het intestinale, deels diffuse type, niet multifocaal aanwezig; het stoma toonde een matige focale ontsteking, duidelijk intestinale metaplasie, mild tot matige dysplasie; het corpus toonde een maing focale ontsteking, focale intestinale metaplasie, focale atrofie en licht tot matige dysplasie. Postoperatief deden er zich aanvankelijk geen problemen voor; de vijfde dag postoperatief ont stond een ernstig respiratoire insufficiëntie met cardiale ritmestoornissen. Patient is overleden, bij obductie werd een grote longembolie vastgesteld, het operatiegebied toonde geen bijzonderheden.

patiènt 2: man, geboren in 1916; BII-resectie in 1950 in verband met een ulcus duodeni. Gastroscopie in 1970 in werband met 10 jaar bestaande maagklachten, waarvoor bij herhaald röntgenonderzock geen verklaring kon worden gegeven. Bij gastroscopie werd in het praestomagebied een grote ulcusput gezien, opgevuld met gallig materiaal. Reresectie volgde. Sedertdien periodiek irritable bowel klachten bij nerveuze en depressieve man. Enkele malen werd gastroscopie: werricht op verzoek van patiënt ter uitsluiting van een ulcus pepticum. Endoscopische bevindingen in 1971 , 1972, 1974, 1975, 1976 en 1979: vrij kleine BII-resectiemaag, rood geinjiceerd stomaslijmwlies, corpusslijmvlies zonder duidelijke afwijkingen. Histologisch onderzoek stoma: slijmwlies van antrumtype, diffuus matig superficiële ontsteking, lichte dysplasie in 1974 en 1979 ; histologisch onderzoek corpus: focaal licht tot matig oppervlakkige ontsteking, talrijke zoutzuurcellen, overigens geen bijzonderheden. In februari 1980 volgde een gastroscopie in het kader van ewen onderzoek op een stompcarcinoom (patiënt is klachtenwiij). Gastroscopie: geringe hoeveelheid gal aanwezig, stomaslijmvlies matig geinjiceerd, ter hoogte van achterwandzijde minimat wittig plekje, niet verdacht voor maligne proces; corpusslijmwlies zonder bijzonderheden. Histologisch onderzoek stoma: diffuus matig superficiële gastritis, matig tot ernstige dysplasie, carcinoom?; histologisch onderzoek corpus: focaal matig superficiële gastritis, overigens geen bijzonderheden. Gezien de bevindingen bij histologisch onderzoek werd besloten tot chirurgische therapie. Een subtotale maagresectie met Roux-Y-anastomose werd verricht, tevens vond cholecystectomie plaats in verband met een galsteenlijden. Het maagresectiepreparaat toonde intact slijmvlies zonder bijzonderheden. Histologisch onderzoek toonde multi-focaal een intramucosaal carcinoom van het intestinale type. Ter hoogte van het stoma werd een gering opperwlakkige ontsteking gezien, geen intestinale metaplasie, een licht tot matige dysplasie. Het corpusslijmvlies toonde histologisch een lichte dysplasie, owerigens geen bijzonderheden. Postoperatief hebben zich geen problemen woorgedaan. In wisselende mate was er sprake van atypische buikklachten, bij gastroscopie werd in het stomagebied eên persisterende hechtdraad met ulceratieve laesie vastgesteld. In cen periode van ernstige depressie pleegde patiënt suïcide in 1982.

patiënt 3: man, geboren in 1917; BII-resectie in verband met en ulcus duodeni. In verband met een recidief ulcus ter hoogte van het stoma werd in 1953 een reresectie verricht. Patiënt was gedurende vele jaren bekend met atypische buikklachten, toegeschrewen aan een irritable bowel syndroom. In 1979 wolgt opname in verband met een sub-ileus. Bij röntgenonderzoek van het colon werd een strictuur gezien ter hoogte van de overgang sigmoïd-colon descendens, bij coloscopie werd geen slijmvliespathologie vastgesteld. Bij operatie werden veel adhaesies gezien, er bleek een lang sig- 
moid aanwezig, dat afgeknik" werd door adhaesies. Overigens toonde de buik bij inspectie geen bijzonderheden. Postoperatief was patiënt klachtenvrij, bij redelijke eetlust nam hij in gewicht toe. In augustus 1981 volgde een gastroscopie in het kader van een onderzoek op een stompcarcinoom. Gastroscopie: middelgrote BII-resectiemaag met galmeertje; matig geinjiceerd stomaslijmwlies, licht erosief en verhoogd kwetsbaar ter hoogte van kleine curvatuur-achterwandzijde; micropoliepje ter hoogte van de achterwandzijde, een en ander nauwelijks suspect voor een stompciarcinoom; matig gevlekt corpusslijmvlies. Histologisch onderzoek stomabiopt: slijmwlies deels antrum", deels corpuskarakter, diffuus licht superficiële ontsteking, intramucosaal carcinoom, geen dysplasie; histologisch onderzoek corpusbiopt" geen tekenen van ontsteking, ruim voldoende zoutzuurcellem. Besloten werd tot chirurgische therapie, waarbij een sub-totale maagresectie met Roux-Y-anastomose werd verricht. Het maagresectiepreparaat toonde bij het stoma aan de zijde van de afwoerende lis een onregelmatig oppervlak van het slijmvlies met een haemorragische plek. Histologisch onderzoek toonde een intramucosaal carcinoom van het intestinalle type, niet multi-focatal aanwezig. Ter hoogte van het stoma bleek elders geen intestinale metaplasie of dysplasie aanwezig te zijn. Het corpus toonde histologisch focalle atrofie en focaal intestinale metaplasie, overigens geen bijzonderheden. Postoperatief hebben er zich geen problemen voorgedaan. Bij poliklinische controle in februari 1983 bleken er atypische buikklachten aanwezig, redelijk reagerend op symptomattische therapie.

patient 4: man, geboren in 1917; BII-resectie in 1945 in verband met ulcus ventriculi. Vanaf operatie geen maag-darmklachtefn. In 1979 myocardinfarct en caverneuze longtuberculose. Door huisarts verwezen woor onderzoek op stompcarcinoom in oktober 1982. Gastroscopie: middelgrote BII-resectiemaag, veel gal ter hoogte van de restmaag aanwezig; stoma toonde een matig geinjiceerd slijmvlies, aan grote curvatuur-voorwandzijde stoma oppervlakkig ulceratief plekje, $3 / 4 \mathrm{~cm}$ in doornsee; ter hoogte van voorwandzijde stoma langwerpig ulceratieve laesie, $_{1} 1,5 \times 0,5 \mathrm{~cm}$, niet maligne van aspect; licht geinjiceerd corpusslijmvlies, overigens geen bijzonderheden; een en ander endoscopisch niet duidelijk suspect voor een maligne proces, op klinische gronden (interval 37 jaar, geen klachten bij ulceratieve laesie) wel verdacht. Histologisch onderzoek stomabiopt: stomaslijmwies van corpustype, geen tekenen onsteking, ulcererend carcinoom van diffuse type, elders in stom licht tot matige dysplasie; histologie corpusbiopt: geen ontsteking, voldoende zoutzuurcellen, overigens geen bijzonderheden. Een totale magresectie met Roux-Y-anastomose werd verricht. Het maagresectiepreparaat toonde ter hoogte van het stoma aan de voorwandzijde enkele ulceratieve laesies, macroscopisch niet verdacht voor een maligne proces. Histologisch onderzoek toonde een to-tal intramucosale tumorhaardjes van het diffuse type; elders toonde het stoma een licht tot matige dysplasie, overigens geen bijzonderheden. Histologisch onderzoek wan het corpus van de maag toonde geen bijzonderheden. Postoperatief hebben er zich geen bijzonderheden voorgedaan. Patiënt verkeerde in februari 1983 in een goede algemene conditie.

patiênt 5: man, geboren in 1915; BII-resectie in 1946 in verband met een ulcuslijden (ulcus duodeni of ullcus ventriculi?). Sedert de operatie geen maag-darmklachten of andere bijzonderheden. Patiënt werd in september 1981 door de huisarts verwezen voor endoscopie in verband met een onderzoek op een stompcarcinoom. Gastroscopie: middelgrote BIL-resectiemaag, nauwelijks gal aanwezig; de stomarand toonde een matig geinjiceerd slijmwlies, praestomaal bevond zich aan de voorwandzijte een plooiconvergentie, ietwat onregelmatige plooien met enkele haemorragische plekjes, cen en ander nawwelijks suspect voor een maligne proces; het corpusslijmvlies leek ietwat atrofisch te zijn. Histologisch onderzoek stoma: slijmvlies van antrumtype, diffuus matig superficięle ontsteking. Iocaal matige dysplasie. Histologisch onderzoek corpus: diffuus licht oppervlakkige ontsteking; intestinale metaplasie, matige dysplasie ${ }_{n}$ atrofische gastritis mett duidelijk verminderd auntal zoutzuurcellen. In verband met deze bevindingen werd een controle-endoscopie verricht na ongeveer 2 maanden. Gastroscopie: bevindingen zoals bij voorgaande endoscopie. Histologisch onderzoek stoma: carcinoom van het intestinale type, overige bevindingen zoals bij vorig onderzoek. Een totale maagresectie met Roux-Y-anastomose werd verricht. Het malagresectiepreparmat toonde macroscopisch in de regio van het stoma geen verdachte laesies. Histologisch onderzock van het stoma toonde een intramucosaal carcinoom van het intestinale type, multi-focaal aanwezig; het stoma toonde elders een lichte ontsteking, geringe dysplasie; het corpus toonde geen ontsteking van betekenis ${ }_{\text {w }}$ ocaal intestinale metaplasie en atrofie. Postoperatief hebben er zich geen bijzonderheden voorgedaan, patiënt verkeerde in februari 1983 in een goede algemene conditie. 


\subsubsection{Ziektegeschiedenis van de niet-carcinoom patiënten met endoscopisch afwijkende beelden}

patiënt 6: man, geboren in 1905; BII-resectie in 1941 in werband met een ulcus duodeni. Sedert operatio geen maagklachten. Door huisarts verwezen in mei 1982 woor endoscopie in verband mat onderzoek op een stompcarcinoon. Gastroscopie: middelgrote B Il-resectemaag, duidelijk gal armwezig ter hoogte van restmag, stomastijnvlies duidelijk oedenoteus en geinjioeerd, ter hoogte van stoma aan voorwand-kleine curvatuurzijde gebiedje, $2 \mathrm{x} 2 \mathrm{~cm}$, wan fijn brokkelig weefsel, matig suspect woor een maligne proces; wisselend geinjiceerd corpusshijmwlies, overigens geen bijzonderheden. Histologisch onderzoek stoma: ter hoogte van witig waefsel slijinvlies van antrumk al rakter, uitgebreid intestinale metaplasie, op vrij uitgebreide schaal matige dysplasie; biopten elders uit stoma toonden dezelfde afwijkingen, al was dysplasie hier niet zo uitgebreid. Histologisch onderzoek corpus: matig chronisch atrofierende gastritis met intestinale metaplasie en plaatselijk lichte eprtheeldysplasie. Zowel gezien de bevindingery op endoscopisch als histologisch terrein, was een controle-endoscopie met multipele biopten van de stomaregio geindiceerd. Patient was klachtenvrij in februari 1983, wilde hernicuwd encloscopisch onderzok niet onder. gatan.

patiënt 7: man, geboren in 1910; BII-resectie in 1938 in verband met ulcus duodeni. Sedert operatie geen maagklachten, onder medische controle in verband met een lichte hypertensie. Voor endoscopie in het kader van een onderzoek op stompcarcinoom werd patient verwezer in oktober 1982. Grastroscopie: middelgrote Bl.-resectiamaag, nauwelijks gal ter hoogte van de restmaag anwwzig. De stomarand wertoonde duidelijk geinjiceerd slijmvlies, ter hoogte van de kleine curvatuurzijde stug aandoend (bij palpatie met de gesloten biopsietang niet geinfiltreerd afuvoelend), met diverse wittige plekjes, enigszins suspect voor een maligne proces; het corpus toonde eveneens eet duidelijk geinjiceerd slijmvlies. Histologisch onderzoek stoma: slijmvlies van antrumtype, gering chronische ontstekingsactiviteit, plaatselijk licht oppervlakkige epitheeldysplasie. Histologisch onderzoek corpus: gering diffuse ontsteking, lichte ontstekingsdysplasie oppervlakte aepitheel, aantal zoutzunrcellen verminderd. Controle-endoscopisch onderzoek van deze patient werd ge pland een jaar na dit onderzoek. Patiènt verkeerde in een goede algenene conditie in februari 1983.

patiënt 8: man, geboren in 1902; BIl-resectie in 1947 in verband met ulcuslifden (ulcus duodeni of ulcus ventriculi?). Na operatie geen maagklachten meer, cholecystectomie in 1957. Voor endoscopie in het kader van een onderzoek ap stompcarcinoom werd patient verwezen in jun: 1982. Gastroscopie: middelgrote Bll-resectiemaag, ter hoogte van restmatg was veel gal aanwezig. Stornarand toonde duidelijk oedemateus en geinjiceerd slijmvlies, verhoogd kwetsbaar atn de grote curwatuur-woorwandzijde; ter hoogte van de klleine curvatuurzijde diverse wittige plekjes op ongeveer $1.5 \mathrm{~cm}$ van stoma; op ongeveer $4 \mathrm{~cm}$ praestomaal aan de voorwandzijde licht verheven wittig slijmvliesgebiedje, $1,5 \times 1,0 \mathrm{~cm}$, adenomateus van aspect, enigszins suspect voor een maligne proces. Histologisch onderzoek stoman slijmvlies van antrumkarakter, matig diffuse ontsteking, platselijk intestinale metaplasie, matuge dysplasie; adenomateus slimvlies toonde entrelfde beeld met licht tot matige epitheeldysplasie. Histologisch onderanek corpus: gering chronische ontsteking, uitgebreid intestimale metuplasie, verminderd antal zoutzumoellen. In verlyand met deze bevindingen bij endoscopisch en histologisch onderzoek werd een controle-gastroscopie na drie maanden verricht, warbij endoscopisch eenzelfde beeld werd gezien. Histologusch onderzoek wan stomabiopten toonde geen opvallende ontstekingsactiviteit, platselijk intestinale metaplasie, plaatselijk lichte dysplasie. Meerdere biopten van het adenomateuze weefse: toonden adenomateuze dysplasie. De endoscopie werd gecomplicedro door een ernstige nabloeding. warwoor opname in het ziekenhuis noodzakelijk was. Tot dusver heeft patient controlk-endoscopisch onderzoek geweigerd. Hij werkeerde iu februari 1983 in een goede algemene conditic.

patiënt 9: man, geboren in 1916; BII-resectie in 1942 in verband met eeti ulcus duodeni. Sedert operatich geen maagklachten. Voor onderzoek op een stompcarcinoom werd patient verwezen in april 1980. Gastroscopie: middelgrote BIl-resectiemag, matige hoeveelheid gal aanwezig; duidelijk adenomateus slijmvlies ter hoogte wan stoma, fors nabloedend bij bioptenten; ter hoogte wan voorwandzijde corpus 2 slijmwliesflappen, aardbei-achtig van aspect, $1.5 \times 0,75 \mathrm{~cm}$ groot. Histologisch onderzoek stoma: slijmvlies van antrumtype, gering diffuse ontsteking, platatselijk intestinale metaplasie, geringe epitheeldysplasie, biopsie ter hoogte van slijmwliesflappen: wisselende ontstekingsactiviteit, focaal sterk intestinale metaplsie, plaatselijk matige dysplasie. Bij hernieuwd endoscopisch onderzoek werden met eer diathermiesnaar de slijmvliestlappen verwijderd; histologisch onderzoek toonde slijmwlies met adenomateuze veranderingen en matige dysplasie. Endoscopisch werd patiènt wervolgd, het stomat toonde aan de voorwandzijde wittig, verhoogd laedeerbaar slijmvlies, het corpus toonde op de plaats waar de slijmvliesflappen verwijderd waren een gebiedje met wittig slijmvlies, minimaal verhewen boven thet slijmvlies in dew di- 
recte omgeving. Bij herhaling genomen biopten uit stoma en woonwandzijde corpus toonden tekenen van chronische ontsteking, intestinale metaplasie, in nogal wisselende mate dysplasie (variërend van licht tot matig ernstig). Een van de endoscopieen werd gevolgd door een emstige na. bloeding, waarrvoor opname in het ziekenhuis noodzakelijk was. Endoscopisch onderzoek toonde bij herhaling weer hetzelfde beeld, bij histologisch onderzoek bleek in wisselende mate dysplasie aanwezig te zijn. Een duidelijk verhoogd risico op een stompcarcinoom leek bij patiênt aanwezig. Met hem werden de behandelingsmogelijkheden besproken. Hoewel voor dat mow ment een maagresectie niet noodzakelijk geacht werd, werd mede op aandringen van patiènt (ernstig ongerust over zijn malagkwaal, echtgenote overleden aan een maagcarcinoom), hiertoe in onderling owerleg toch besloten. Een subtotale maagresectie met een Roux-Y-anastomose werd verricht. Het maagresectiepreparaat toonde in het stomagebied duidelijk erosief slijmvlies, ter hoogte van de voorwandzijde van het corpus een wittig slijmvlies. Histologisch onderzoek van het stoma toonde een chronisch agressief locaal erosieve gastritis met lichte tot matige epitheeldysplasie. Het stoma werd geheel opgesneden, toonde nergens dysplasie van een hogere graad dan gering tot matig. Het wittige slijmvliesgebied aan de voorwandzijde toonde een soortgelijk beeld. Postoperatief hebben zich geen bijzonderheden woorgedaan. Ongeveer 6 maanden postoperatief bleek patiënt in februari 1983 klachtenvrij, in een goede algemene conditie te verkeren.

\subsection{Samenvatting van de onderzoekgegevens}

Uit onderzoek komen de volgende gegevens naar woren:

- bij 138 klachtenvrije patiënten, endoscopisch en histologisch onderzocht in de periode 1980 tot en met 1982, meer dan 10 jaar na een BII-resectie kwam encloscopisch-macroscopisch geen evident maligne pathologie naar voren;

- histologisch werd bij 5 patiënten gemiddeld 34.4 jaar na de primaire operatie een intramucosaal carcinoom ter hoogte van het stoma vastgesteld (viermaal van het intestinale type, eenmaal van het diffuse type), driemaal multi-focaal van origine; endoscopisch bleken bij deze patiënten geringe slijmvliesafwijkingen te bestaan; bij 3 patiënten bleek ter hoogte van het stoma een matige dysplasie aanwezig;

- bij 4 niet-carcinoompatiënten werden bij endoscopie slijmvliesafwijkingen gezien wijzend op de mogelijk heid var een carcinoom; bij 3 van deze patiënten bleek histologisch een matige dysplasie ter plaatse van de slijmwliesafwijking aanwezig;

- bij 13 patienten werden geringe slijmvliesafwijkingen gezien, zoals ook bij de carcinoompatiënten, in de vorm van wittige slijmvliesplekken en een verhoogd kwetsbaar slijmvlies; bij 2 van deze patiënten bleek histologisch een matige dysplasie ter hoogte van het stoma aanwezig;

- bij 9 patienten werd ter hoogte van het stoma histologisch een matige dysplasie vastgesteld; gemiddelde leeftijd en interval van deze patiënten kwamen overeen met de gemiddelde waarden hiervan bij de carcinoompatiënten;

- de 5 carcinoompatiënten onderscheidden zich klinisch op geen enkele wijze van de niet-carcinoompatiënten;

- de prognose van de geopereerde carcinoompatiènten (subtotale maagresectie met Roux-Yprocedure) lijkt goed te zijn;

- zeer frequent werd histologisch ter hoogte van het stoma een cysteuze verwijding van klierbuizen gezien $(74.4 \%)$; dit zou opgevat kunnen worden als een kenmerkende afwijkende bevinding van het stomaslijmulies;

een lichte dysplasie van het stomaslijmvlies was een zeer frequente bevinding bij histologisch onderzoek. 


\section{Hoofdstuk 8}

\section{Endoscopisch en histologisch onderzoek van BI-ma- gen, meer dan 10 jaar postoperatief, in verband met klachten, in de periode 1970 tot en met 1979}

In de periode 1970 tot en met 1979 werden 57 patiënten met een BI-resectiemaag meer dan 10 jaar na de operatie, endoscopisch onderzocht in verband met klachten, toegeschreven aan een aandoening van de restmaag. Een vergelijkbare groep patiënten werd in de periode 1980 tot en met 1982 onderzocht volgens een tevoren vastgestelde procedure (tenminste 4 biopsieèn ter hoogte van de stomaregio, tenminste 4 biopsieën ter hoogte van de corpusregio). Waar zulks niet het geval geweest is in het tijdwak 1970 tot en met 1979 , bovendien het weefselmateriaal uit deze periode niet altijd in optimale hoeveelheid aanwezig bleek, worden de omschreven groepen patiënten apart besproken.

Van deze 57 patiënten bleken 2 patiënten een carcinoom in de restmaag te hebben.

Van de carcinoom-en niet-carcinoompatiënten worden de gemiddelde leeftijd op het moment van het onderzoek en het gemiddelde tijdsinterval vanaf de operatie met variatie en standaarddeviatie vermeld in Tabel 8.1 .

Tabel 8.1. Patiënten met een BI-maag met klachten, onderzocht meer dan 10 jaar postoperatief, in de periode 1970 tot en met 1979 .

\begin{tabular}{|c|c|c|c|c|c|}
\hline & \multirow{2}{*}{$\begin{array}{c}\text { aantal } \\
\text { patienten }\end{array}$} & \multicolumn{2}{|c|}{ geslacht } & \multirow{2}{*}{$\begin{array}{l}\text { gemiddelde } \\
\text { leeftijd } \\
\text { (variatie en SD) }\end{array}$} & \multirow{2}{*}{$\begin{array}{l}\text { gemiddelde } \\
\text { tijdsinterval } \\
\text { (variatie en } S D \text { ) }\end{array}$} \\
\hline & & $\operatorname{man}$ & vrouw & & \\
\hline \multirow{3}{*}{$\begin{array}{l}\text { patiënten } \\
\text { totaal } \\
\text { patiënten met } \\
\text { carcinoom } \\
\text { patiënten zonder } \\
\text { carcinoom }\end{array}$} & 57 & 43 & 14 & \multirow{3}{*}{$\begin{array}{l}\text { S7.7 jr }(37-85 \mathrm{jr} \\
\text { S.D. } 12.4 \mathrm{jr}) \\
73.0 \mathrm{jr}(73-73 \mathrm{jr} \\
\text { S.D. } 0.0 \mathrm{jr}) \\
\text { 57.1 jr(37-85.jr } \\
\text { S.D. } 12.3 \mathrm{jr})\end{array}$} & \multirow{3}{*}{$\begin{array}{l}19.6 \mathrm{jr}(11-41 \mathrm{jr} \\
\text { S.D. } 8.3 \mathrm{jr}) \\
28.0 \mathrm{jr}(15-41 \mathrm{jr} \\
\text { S.D. } 18.4 \mathrm{jr}) \\
19.3 \mathrm{jr}(11-41 \mathrm{jm} \\
\text { S.D. } 7.9 \mathrm{jr})\end{array}$} \\
\hline & $2(3.5 \%)$ & 2 & - & & \\
\hline & $55(96.5 \%)$ & 41 & 14 & & \\
\hline
\end{tabular}

De gegevens van de anamnese, endoscopisch en histologisch onderzoek worden voor de carcinoom-en niet-carcinoompatiënten apart vermeld.

\subsection{Gegevens van de anamnese}

De indicaties voor de primaire operatie worden gegeven in Tabel 8.2.

Tabel 8.2.Indicaties voor primaire operatie van de 57 patiënten met een BI-maag

\begin{tabular}{llllll}
\hline & $\begin{array}{l}\text { gantal } \\
\text { patienten }\end{array}$ & UD & UV & UD of UV & $\begin{array}{c}\text { anderegocdacige } \\
\text { aandocming }\end{array}$ \\
\hline $\begin{array}{l}\text { patienten met } \\
\text { carcinoom }\end{array}$ & 2 & - & $2(100 \%)$ & $\cdots$ & $\cdots$ \\
$\begin{array}{l}\text { patiënten zonder } \\
\text { carcinoom }\end{array}$ & 55 & $16(29.1 \%)$ & $7(12.7 \%)$ & $28(50.9 \%)$ & $4(7.3 \%)$ \\
\hline
\end{tabular}

De vanuit de anamnese naar voren komende klachten wan de 55 niet-carcinoompatiënten worden in Tabel 8.3. vermeld. 
Tabei 8.3. Kiechen wan de 55 niet-carcinoompatienten met een BI-maag

\begin{tabular}{lcc}
\hline klachten/anal patienten & ABS & $\%$ \\
& $n=55$ & \\
\hline eettlust verminderd & 28 & 50.9 \\
vermagering & 28 & 50.9 \\
aantal kg. vermagering & 170 & 6.1 \\
zuurbranden & 9 & 60.4 \\
opboeren & 33 & 54.5 \\
misselijkheid & 30 & 30.9 \\
overgeven & 17 & 67.3 \\
pijn & 37 & 12.7 \\
druk, opgezet gevole.d. & 7 & \\
\hline
\end{tabular}

* 28 patiénten wermageren in totaal $170 \mathrm{~kg}$.

$=$ gemiddeld $6.1 \mathrm{~kg}$. per vermagerde patiënt

$=$ gemiddeld $3.1 \mathrm{~kg}$. per patiënt

De 2 careinoompatiënten klaagden beiden over een verminderde eetlust, vermagerden 10 en 28 $\mathrm{kg}$, hadden overigens als symptomen zuurbranden ( 1 patiënt), opboeren (1 patiënt), misselijkheid (1 patiënt), overgeven ( 2 patiënten) en pijn (1 patuënt).

\subsection{Gegevens van de endoscopie}

De algemene gegewens van het endoscopisch onderzoelk van de 55 niet-carcinoompatinten worden vermeld in Tabel 8.4. De bijzonderheden naar voren gekomen bij dit onderzoek worden weergegeven in Tabel 8.5 .

Tabel 8.4. Algemene endoscopische gegevens van de 55 niet-carcinoompatiënten met een BI-maag

\begin{tabular}{|c|c|c|c|}
\hline \multicolumn{2}{|c|}{ endoscopjegegevens/aantal patienten } & \multirow{2}{*}{$\begin{array}{c}A B S \\
n=55 \\
48\end{array}$} & \multirow{2}{*}{$\begin{array}{c}\% \\
87.3\end{array}$} \\
\hline stoma & normaal & & \\
\hline & plooiconvergentie & 7 & 12.7 \\
\hline \multirow{4}{*}{ stomagastritis } & stenose & 0 & 0.0 \\
\hline & geen & 4 & 7.3 \\
\hline & matig & 24 & 43.6 \\
\hline & duidelijk & 27 & 49.1 \\
\hline \multirow[t]{3}{*}{ corpusgastrit is } & geen & 22 & 40.0 \\
\hline & matig & 31 & 56.4 \\
\hline & duidelijk & 2 & 3.6 \\
\hline \multirow[t]{4}{*}{ hoeveellheid gall } & geen & 2 & 3.6 \\
\hline & matig & 5 & 9.2 \\
\hline & duidelijk & 1 & 1.8 \\
\hline & onbekend & 47 & 854 \\
\hline
\end{tabular}

Tabel 8.5. Bijzondere endoscopische bevindlingen bij de 55 niet-carcinoompatiënten met een BI-maag

\begin{tabular}{lcc}
\hline endoscopie gegevens/antal patiennten & ABS & $\%$ \\
\hline forse pllooien stoma & $n=55$ & 10.9 \\
witte plekken stomat & 6 & 1.8 \\
ulcus duodeni & 1 & 1.8 \\
ulcus stoma & 1 & 1.8 \\
ulcus prestoma & 4 & 7.3 \\
erosie stoma & 1 & 7.3 \\
xantelasmata & 4 & 1.8 \\
poliepen & 1 & \\
\hline
\end{tabular}

Endoscopisch onderzoek liet bij 2 patiënten een carcinoom van de resectiemaag zien (zie figuur 8.1).

De afwijkingen bij deze patiënten kunnen als wolgt worden omschreven: 


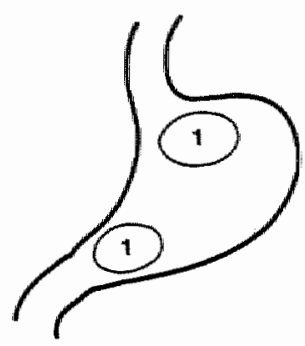

Figuur 8.1.

Localisatie van de 2 carcinomen in de BI-maag

patiënt 1: ter hoogte van het stoma circulair proliferatieve plooien, wijzend op een maligne proces;

patiënt 2: ter hoogte van de proximale maag vrijwel circulair proliferatief-ulceratief proces, wijzend op cen maligne proces.

De bijzondere endoscopische bevindingen van de 55 niet-carcinoompatiënten worden vermeld in Tabel 8.5 .

\subsection{Gegevens van histologisch onderzoek}

Van de 2 patienten met een voor maligniteit verdachte afwijking in de restmaag, werd bij I patiënt de diagnose bevestigd via histologisch onderzoek van de bij endoscopie genomen biopten.

Tabel 8.6. Gegevens van histologisch onderzoek van de 55 niet-carcinoompatiënten met een Bl-maag ( 54 stoma- en 50 corpusbiopsieën)

\begin{tabular}{|c|c|c|c|c|}
\hline \multicolumn{3}{|c|}{ histologischegegevens/aantal patiënten } & \multirow{2}{*}{$\begin{array}{c}A B S \\
n=54 / 50 \\
11\end{array}$} & \multirow{2}{*}{$\begin{array}{c}\% \\
20.4\end{array}$} \\
\hline $\bar{s}$ & slijmwlieskarakter stoma & antrum & & \\
\hline & & corpus & 42 & 77.8 \\
\hline & & antrum/corpus & 1 & 1.8 \\
\hline \multirow[t]{3}{*}{$\mathrm{T}$} & ontsteking stoma & geen & 2 & 3.7 \\
\hline & & focaal & 1 & 1.8 \\
\hline & & diffuus & 51 & 94.5 \\
\hline \multirow[t]{3}{*}{0} & ontsteking stoma & geen & 2 & 3.7 \\
\hline & & licht & 20 & 37.0 \\
\hline & & matig & 30 & 55.6 \\
\hline \multirow[t]{3}{*}{$\mathrm{M}$} & & ernstig & 2 & 3.7 \\
\hline & cysteuze verwijding & & 32 & 58.2 \\
\hline & intestinale metaplasie & & 4 & 7.3 \\
\hline \multirow[t]{2}{*}{ A } & dysplasie & licht & 9 & 16.7 \\
\hline & & matig & 1 & 1.8 \\
\hline \multirow[t]{3}{*}{$\bar{C}$} & ontsteking corpus & geen & 10 & 20.0 \\
\hline & & focaal & 2 & 4.0 \\
\hline & & diffuus & 38 & 76.0 \\
\hline \multirow{3}{*}{0} & ontsteking corpus & geen & 10 & 20.0 \\
\hline & & licht & 20 & 40.0 \\
\hline & & matig & 18 & 36.0 \\
\hline \multirow[t]{3}{*}{$\mathbb{R}$} & & ernstig & 2 & 4.0 \\
\hline & cysteuze verwijding & & 5 & 10.0 \\
\hline & intestinale metaplasie & & 3 & 6.0 \\
\hline \multirow[t]{3}{*}{ P } & dysplasie & licht & 0 & 0.0 \\
\hline & & matig & 0 & 0.0 \\
\hline & atrofische gastritis & & 18 & 36.0 \\
\hline \multirow[t]{3}{*}{$\mathrm{U}$} & zoutzuurcellen & voldoende & 33 & 66.0 \\
\hline & & verminderd & 13 & 26.0 \\
\hline & & afwezig & 4 & 8.0 \\
\hline
\end{tabular}


Van de tweede patient toonde het biopt verdachte cellen en werd de diagnose definitief bevestigd via onderzoek van bij obductie verkregen weefsel.

Van de carcinomen bleek 1 carcinoom van het intestinale fype te zijn en 1 carcinoom van het diffuse type.

Bij een van de patiénten werd er ter hoogte van het stoma een matige dysplasie gevonden, het stomabiopt wan de andere patiënt was hierop niet te beoordelen. Van de niet-carcinoompatiënten worden de bevindingen van histologisch onderzoek vermeld in tabel 8.6 . Van 1 patiënt bleken de stomabiopten niet te beoondelen, wan 5 patiënten werden er geen corpusbiopsieën genomer:

Het fenomeen matige dysplasie werd ter hoogte van het stoma zelden gezien: eenmaal bij een van de carcinoompatiënten (stomabiopten van de andere carcinoompatiënt bleken hierop niet te beoordelen), eenmaal bij een van de 54 niet-carcinoompatiënten. Ten dele kan dit geringe aantal matige dysplasieén toegeschrewen worden aan het beperkte aantal stomabiopsieën (meestal 1 biopsie per patiënt j dat bij onderzoek werd genomen.

\subsection{Ziektegeschiedenis van de carcinoompatiënten}

patiënt 1: man, geboren in 1901; B.I-resectie in 1959 in verband met ulcus ventriculi. In februari 1974 werd patiënt voor onderzoek verwezen in werband met 3 maanden bestaande klachten over verminderde cetlust, vermagering van $10 \mathrm{~kg}$., zuurbranden, opboeren, overgeven en pijnen in epigastrio. Gastroscopie: middelgrote BI-resectiemaag; rond stoma proliferatief veranderde plooien; ter hoogte varn corpus tekenen wan een atrofische gastritis. Histologisch onderzoek toonde het beeld wan een carcinoom van het diffuse type, ter hoogte van het stoma bleek een matige dysplasie aanwezig, intestinale metaplasie werd gezien ter hoogte van stoma en corpus van de restmaag; het corpus toonde een atrofische gastritis met sterk verminderd aantal zoutzuurcellen. Bij operatie werd vlak voor de anastomose een harde tumor gepalpeerd, ter hoogte van het ligamentum hepatoduodenale bleek een hard kliertje aanwezig; de restmaag werd voor de helft gereseceerd, retrocolisch werd end to side een anastomose maagstomp-jejunum aangellegd. Onderzoek wan het resectiepreparaat toonde een schotelvormige tumor, doorsnee $5.5 \mathrm{~cm}$., ter hoogte van de grote curvatuurzijcle; bij histologisch onderzoek bleek een carcinoom van het diffuse type aanwezig, met doorgroei tot de serosa; lymfkliermetastasen bleken aanwezig. In april 1974 is patiënt overleden.

patiënt 2: man, geboren in 1899; Bl-resectie in 1931 in verband met ulcus ventriculi. Sedert 1967 in toenemencle mate pijnen in epigastrio in aansluiting aan de maaltijd, af en toe overgeven, gewichtsvermindering van $28 \mathrm{~kg}$. gedurende het laatste jaar. Patiënt weigerde onderzoek, werd opgenomen in cachectische toestand in september 1972. Gastroscopie: middelgrote BI-resectiemaag; distale malag niet afwijkend; ter hoogte van proximale maag vrijwel circulair aanwezig uitgebreid proli* feratief-ulceratief proces, maligne van aspect; beeld reflux-oesophagitis. Bij histologisch onderzock werd het beeld wan een ulceratieve laesie met sterk atypische cellen gezien, de diagnose maligniteit was hierop niet met zekerheid te stellen. Patient is in oktober 1972 overleden. Bij obductie werd een uitgebreid magcarcinoom van het intestinale type vastgesteld, metastasen bleken alawwezig te zijn.

\subsection{Samenvatting van de onderzoekgegevens}

Bij dit onderzoek komen de volgende gegevens naar voren:

- bij 57 patiennten (gemiddelde leeftijd 27.3 jaar, gemiddeld interval 19.3 jaar), in de periode 1970 tot en met 1979 endoscopisch en histologisch onderzocht in verband met klachten meer dan 10 jaar na een BI-resectie, werd bij 2 patiënten (leeftijd 73 jaar, interval 15 en 41 jaar) histologisch een carcinoom vastgesteld (eenmal van het intestinale type, eenmaal van het diffuse type);

- bij histologisch onderzoek werd een matige dysplasie ter hoogte van het stoma gezien bij 1 van de 2 patiënten met een carcinoom (stomaslijmvlies van de andere patiënt hierop niet te beoordelen); een matige dysplasie van thet stomaslijmvlies $\mathrm{kwam}$ bij slechts 1 van de 54 niet-carcinoompatiënten voor, hetgeen ten dele toe te schrijven zal zijn aan het geringe aantal biopsieën ter hoogte van het stoma;

- bij histologisch onderzoek werd een cysteuze verwijding van de klierbuizen van het stomaslijmvlies gezien bij $58.2 \%$ van de niet-carcinoompatiënten. 


\section{Hoofdstuk 9}

\section{Endoscopisch en histologisch onderzoek van BI-ma- gen, meer dan 10 jaar postoperatief, in verband met klachten, in de periode 1980 tot en met 1982}

In de periode 1980 tot en met 1982 werden 49 patiënten met een BI-resectiemaag, meer dan 10 jaar postoperatief endoscopisch onderzocht in verband met klachten, welke toegeschreven werden aan een aandoening van de restmaag.

Carcinomen werden in deze groep noch endoscopisch, noch histologisch vastgesteld.

Van de patiënten worden de gemiddelde leeftijd op het moment van het onderzoek en het gemiddelde tijdsinterval vanaf de operatie met variatie en standaarddeviatie vermeld in Tabel 9.1.

Tabel 9.1. Patiènten met een BI-maag met klachten, onderzocht meer dan 10 jaar postoperatief, in de periode 1980 tot en met 1982 .

\begin{tabular}{|c|c|c|c|c|c|}
\hline & \multirow{2}{*}{$\begin{array}{c}\text { aantal } \\
\text { patienten }\end{array}$} & \multicolumn{2}{|c|}{ geslacht } & \multirow{2}{*}{$\begin{array}{l}\text { gemiddelde } \\
\text { leeftijd } \\
\text { (variatic en SD) }\end{array}$} & \multirow{2}{*}{$\begin{array}{l}\text { gemiddelde } \\
\text { tijdsinterval } \\
\text { (variatie en SD) }\end{array}$} \\
\hline & & man & vrour & & \\
\hline patiênten & 49 & 39 & 10 & $\begin{array}{l}61.5 \mathrm{jr}(30-95 \mathrm{jr} \\
\text { S.D. } 15.9 \mathrm{jr})\end{array}$ & $\begin{array}{l}20.7 \mathrm{jr}(11-54 \mathrm{jr} \\
\text { S.D. } 9.2 \mathrm{jr})\end{array}$ \\
\hline
\end{tabular}

\subsection{Gegevens van de anamnese}

Indicaties voor de primaire operatie worden gegeven in Tabel 9.2.

Tabel 9.2. Indicaties voor primaire operatie van de 49 patiënten met een BI-maag

\begin{tabular}{llllll}
\hline & $\begin{array}{l}\text { aantal } \\
\text { patienten }\end{array}$ & UD & UV & UD of UV & $\begin{array}{l}\text { anderegocdardige } \\
\text { andoening }\end{array}$ \\
\hline patiènten & 49 & $16(32.7 \%)$ & $10(20.4 \%)$ & $20(40.8 \%)$ & $3(6.1 \%)$ \\
\hline
\end{tabular}

De vanuit de anamnese naar voren komende klachten worden vermeld in Tabel 9.3.

Tabel 9.3. Klachten wan de 49 patiënten met een BI-maag

\begin{tabular}{|c|c|c|}
\hline klachen/aantal patientes & $\begin{array}{c}A B S \\
n=49\end{array}$ & $\%$ \\
\hline eetlust verminderd & 23 & 46.9 \\
\hline vermagering & 21 & 42.9 \\
\hline aantal $k \mathrm{~g}$. vermagering & 110 & 5.2 \\
\hline zurubranden & 11 & 22.4 \\
\hline opboeren & 20 & 40.8 \\
\hline misselijk heid & 22 & 44.9 \\
\hline overgeven & 14 & 28.6 \\
\hline pijn & 24 & 49.0 \\
\hline druk, opgezet gevoel e.d. & 5 & 10.2 \\
\hline
\end{tabular}

\footnotetext{
* 21 patiënten vermageren in totaal $110 \mathrm{~kg}$

- een gemiddelde van $5.2 \mathrm{~kg}$. per vermagerde patient

$=$ een gemiddelde van $2.2 \mathrm{~kg}$. per patient
} 


\subsection{Gegevens van de endoscopie}

De algemene bevindingen bij endoscopisch onderzoek worden wermeld in Tabel 9.4.

Tabel 9.4.Algemene endoscopie gegevens van de 49 patiënten met een BI-maag

\begin{tabular}{llcc}
\hline endoscopic gegevens/aantal patiënten & ABS & $\%$ \\
& & $n=49$ & \\
\hline \multirow{2}{*}{ stoma } & normal & 48 & 98.0 \\
& plooiconvergentie & 1 & 2.0 \\
stomagastritis & stenose & 0 & 0.0 \\
& geen & 2 & 4.1 \\
matig & 27 & 55.1 \\
& duidellijk & 20 & 30.8 \\
hoeveelheid gal & geen & 18 & 51.0 \\
& matig & 25 & 12.3 \\
& duidelijk & 6 & 49.0 \\
suspect stoma & geen & 24 & 38.8 \\
& matig & 19 & 12.2 \\
& duidelijk & 6 & 2.0 \\
\hline
\end{tabular}

De bijzonderheden, naar voren gekomen bij dit onderzoek, worden weergegeven in Tabel 9.5.

Tabel 9.5. Bijzondere endoscopische bevindingen bij de 49 patiënten met een BI-maag

\begin{tabular}{lcc}
\hline endoscopiegegevens/ántal patiënten & ABS & $\%$ \\
\hline forse plooien stoma & 6 & 49 \\
witte plek ken stoma & 3 & 12.2 \\
ulcus duodeni & 4 & 6.1 \\
ulcus stoma & 1 & 8.2 \\
ulcus praestoma & 1 & 2.0 \\
erosie duodenum/stoma & 2 & 4.1 \\
suspect gebied praestoma & 1 & 2.0 \\
xantelasmata & 4 & 8.2 \\
poliepen & 1 & 2.0 \\
\hline
\end{tabular}

Eenmaal bleck er cen beeld te bestaan, enigszins verdacht woor een maligne proces: ter hoogte van de praestomaregio bevond zich aan de voorwandzijde over een afstand van 5 tot $6 \mathrm{~cm}$ een boven het slijmvliesniveau verheven hobbelig gebied, wittig van aspect, niet geinfiltreerd aanvoelend met de gesloten biopsietang. Histologisch onderzoek toonde een uitgebreid intestinale metaplasic, geen epitheeldysplasie.

De overige bijzondere endoscopische bevindingen van de $49 \mathrm{BI}$-patiënten worden vermeld in Tabel 9.5 .

\subsection{Gegevens van histologisch onderzoek}

De algemene gegevens bij histologisch onderzoek worden vermeld in Tabel 9.6. In deze groep patiënten werd een matige dysplasie slechts bij én patiënt vastgesteld. 
Tabel 9.6. Gegevens van histologisch onderzoek van de 49 patiënten met een BI-maag ( 47 stoma-en 46 corpusbiopsieèn)

\begin{tabular}{|c|c|c|c|c|}
\hline \multicolumn{3}{|c|}{ histologische gegevens/aantal patiënten } & \multirow{3}{*}{$\begin{array}{c}A B S \\
n=47 / 46 \\
15 \\
30\end{array}$} & \multirow{2}{*}{$\begin{array}{r}d 9 \\
31.9\end{array}$} \\
\hline S & slijmvlieskarakter stoma & antrum & & \\
\hline & & corpus & & 63.8 \\
\hline & & antrum/corpus & 2 & 4.3 \\
\hline \multirow[t]{3}{*}{$\mathrm{T}$} & ontsteking stoma & geen & $\overline{9}$ & 19.1 \\
\hline & & focaal & 5 & 10.6 \\
\hline & & diffuns & 33 & 70.3 \\
\hline \multirow[t]{3}{*}{$\mathrm{O}$} & ontsteking storna & geen & 9 & 19.1 \\
\hline & & licht & 18 & 38.4 \\
\hline & & matig & 19 & 40.4 \\
\hline \multirow[t]{3}{*}{ M } & & ernstig & 1 & 2.1 \\
\hline & cysteuze verwijding & & 23 & 48.9 \\
\hline & intestinale metaplasie & & 11 & 23.4 \\
\hline \multirow[t]{2}{*}{ A } & dysplasie & licht & 17 & 36.2 \\
\hline & & matig & 1 & 2.1 \\
\hline \multirow[t]{3}{*}{$\mathrm{C}$} & ontsteking corpus & geen & 13 & 28.3 \\
\hline & & focaal & 8 & 17.4 \\
\hline & & diffuus & 25 & 54.3 \\
\hline \multirow[t]{3}{*}{0} & ontsteking corpus & geen & 13 & 28.3 \\
\hline & & licht & 21 & 45.7 \\
\hline & & matig & 11 & 23.9 \\
\hline \multirow[t]{3}{*}{$\mathbf{R}$} & & ernstig & 1 & 2.1 \\
\hline & cysteuze verwijding. & & 3 & 6.5 \\
\hline & intestinale metaplasic & & 4 & 8.7 \\
\hline \multirow[t]{3}{*}{$\mathbf{P}$} & dysplasie & licht & 0 & 0.0 \\
\hline & & matig & 0 & 0.0 \\
\hline & atrofische gastritis & & 13 & 28.3 \\
\hline \multirow[t]{3}{*}{ U } & zoutzuurcellen & voldoende & 33 & 71.7 \\
\hline & & verminderd. & 7 & 15.2 \\
\hline & & afwezig & 6 & 13.11 \\
\hline
\end{tabular}

\subsection{Samenvatting van de onderzoekgegevens}

Bij dit onderzoek komen de volgende gegevens naar voren:

- bij 49 patiënten (gemiddelde leeftijd 60.7 jaar, gemiddeld interval 20.3 jaar) in de periode 1980 tot en met 1982 endoscopisch en histologisch onderzocht in verband met klachten meer dan 10 jaar na een BI-resectie, werd bij geen van de patiënten een carcinoom vastgesteld;

- bij histologisch onderzoek werd een matige dysplasie ter hoogte van het stoma slechts bij 1 van de 47 hierop onderzochte patiënten vastgesteld;

- bij histologisch onderzoek werd een cysteuze verwijding van de klierbuizen van het stomaslijmvlies gezien bij $48.9 \%$ van de hierop onderzochte patiënten. 


\section{Hoofdstuk 10}

\section{Endoscopisch en histologisch onderzoek van BI-ma- gen, meer dan 10 jaar postoperatief, bij patiënten zon- der klachten, in de periode 1980 tot en met 1982}

In de periode 1980 tot en met 1982 werden 43 symptoomloze patiënten, meer dan 10 jaar postoperatief, endoscopisch en histologisch onderzocht in het kader van een onderzoek op een stompcarcinoom.

Maligne processen werden in deze groep patiënten bij endoscopisch en histologisch onderzoek niet vastgesteld.

Van de patiënten worden de gemiddelide leeftijd op het moment van het onderzoek en het gemiddelde tifdsinterval vanaf de operatie met variatie en standaarddeviatie vermeld in Tabel 10.1.

Tabel 10.1. Patiënten met een BI-maag zonder klachten, onderzocht meer dan 10 jaar postoperatief, in de periode 1980 tot en met 1982.

\begin{tabular}{|c|c|c|c|c|c|}
\hline & \multirow{2}{*}{$\begin{array}{l}\text { aantal } \\
\text { patiënten }\end{array}$} & \multicolumn{2}{|c|}{ gestacht } & \multirow{2}{*}{$\begin{array}{l}\text { gemiddelde } \\
\text { leeftijd } \\
\text { (variatie en SD) }\end{array}$} & \multirow{2}{*}{$\begin{array}{l}\text { gemiddelde } \\
\text { tijdsinterval } \\
\text { (variatic en } S D\end{array}$} \\
\hline & & man & vraw w & & \\
\hline patiënten & 43 & 36 & 7 & $\begin{array}{l}61.4 \mathrm{jr}(40-80 \mathrm{jr} \\
\text { S.D.11.2 jr) }\end{array}$ & $\begin{array}{l}23.0 \mathrm{jr}(11-49 \mathrm{jr} \\
\text { S.D. } 9.8 \mathrm{jr})\end{array}$ \\
\hline
\end{tabular}

\subsection{Gegevens van de anamnese}

De indicaties van de primaire operatie worden gegeven in Tabel 10.2.

Tabel 10.2. Indicaties voor primaire operatie van de 43 pattënten met een BI-maag

\begin{tabular}{llllll}
\hline & $\begin{array}{l}\text { aantal } \\
\text { patienten }\end{array}$ & UD & UV & UD of UV & $\begin{array}{l}\text { andere goedaardige } \\
\text { aandoening }\end{array}$ \\
\hline patiènten & 43 & $17(39.5 \%)$ & $6(14.0 \%)$ & $17(39.5 \%)$ & $3(7.0 \%)$ \\
\hline
\end{tabular}

\subsection{Gegevens van de endoscopie}

De algemene bevindingen bij endoscopisch onderzoek worden vermeld in Tabel 10.3

Tabel 10.3. Algemene endoscopie gegevens van de 43 patiènten met een BI-maag

\begin{tabular}{|c|c|c|c|}
\hline \multicolumn{2}{|c|}{ endoscopie gegevens/antal patiènten } & \multirow{2}{*}{$\begin{array}{c}A B S \\
n=43 \\
42\end{array}$} & \multirow{2}{*}{$\begin{array}{r}\% \\
97.7\end{array}$} \\
\hline stoma & normat al & & \\
\hline & plooiconwergentie & 1 & 2.3 \\
\hline & stenose & 0 & 0.0 \\
\hline \multirow[t]{3}{*}{ stomagastritis } & geen & 5 & 11.6 \\
\hline & matig & 22 & 51.2 \\
\hline & duidelijk & 16 & 37.2 \\
\hline \multirow[t]{3}{*}{ corpusgastritis } & geen & 16 & 37.2 \\
\hline & matig & 23 & 53.5 \\
\hline & duidelijk & 4 & 9.3 \\
\hline \multirow[t]{3}{*}{ hoeveelheidgal } & geen & 23 & 53.5 \\
\hline & matig & 12 & 27.9 \\
\hline & veel & 8 & 18.6 \\
\hline
\end{tabular}

De bijzondere endoscopische bevindingen van de 43 BI-patiënten worden vermeld in Tabel 10.4. 
Tabel 10.4. Bijzondere endoscopische bevindingen bij de 43 patiëten met een BI-maag

\begin{tabular}{|c|c|c|}
\hline endoscopie gegevens/aantal patiënten & $\begin{array}{c}A B S \\
n=43\end{array}$ & $d$ \\
\hline $\begin{array}{l}\text { forse plooien stoma } \\
\text { witte plekken stoma } \\
\text { ulcus stoma } \\
\text { kwetsbaar slijmulies } \\
\text { xantelasmata } \\
\text { poliepen }\end{array}$ & $\begin{array}{l}2 \\
3 \\
1 \\
2 \\
4 \\
2\end{array}$ & $\begin{array}{l}4.6 \\
7.0 \\
2.3 \\
4.6 \\
9.3 \\
4.6\end{array}$ \\
\hline
\end{tabular}

\subsection{Gegevens van histologisch onderzoek}

De algemene gegevens van histologisch onderzoek worden vermeld in Tabel 10.5. Aangezien van 1 patiënt de genomen biopsieèn zoekgeraakt zijn, worden in deze tabel de gegevens van 42 patiënten gemeld.

In deze groep patiënten werd een matige dysplasie ter hoogte van het stoma gezien bij 4 patiëntem $(9.5 \%)$.

Tabel 10.5.Gegevens van histologisch onderzoek van de 43 patiënten met een BI-maag ( 42 stoma- en 42 corpusbiopsieën)

\begin{tabular}{|c|c|c|c|c|}
\hline \multicolumn{3}{|c|}{ histologische gegevens/aantal patiënten } & \multirow{2}{*}{$\begin{array}{c}A B S \\
n=42 / 42 \\
7\end{array}$} & \multirow{2}{*}{$\frac{\%}{16.7}$} \\
\hline$S$ & slijmvlieskarakter stoma & antrum & & \\
\hline & & corpus & 33 & 78.6 \\
\hline \multirow{4}{*}{$\mathrm{T}$} & & antrum/corpus & 2 & 4.7 \\
\hline & ontsteking stoma & geen & 6 & 1.4 .3 \\
\hline & & focaal & 11 & 26.2 \\
\hline & & diffuus & 25 & 59.5 \\
\hline \multirow[t]{3}{*}{$\mathrm{O}$} & ontsteking stoma & geen & 6 & 14.3 \\
\hline & & licht & 13 & 31.0 \\
\hline & & matig & 20 & 47.6 \\
\hline \multirow[t]{3}{*}{ M } & & ernstig & 3 & 7.1 \\
\hline & cysteuze werwijding. & & 11 & 26.2 \\
\hline & intestinale metaplasie & & 9 & 21.4 \\
\hline \multirow{2}{*}{ A. } & dysplasie & licht & 14 & 33.3 \\
\hline & & matig & 4 & 9.5 \\
\hline \multirow[t]{3}{*}{$\mathrm{C}$} & Ontste king corpus & geen & 16 & 38.1 \\
\hline & & focaal & 10 & 23.8 \\
\hline & & diffuus & 16 & 38.1 \\
\hline \multirow{2}{*}{0} & ontsteking corpus & geen & 16 & 38.1 \\
\hline & & licht & 5 & 11.9 \\
\hline \multirow[t]{3}{*}{$\mathbf{R}$} & & matig & 19 & 45.2 \\
\hline & & ernstig & 2 & 4.8 \\
\hline & $\begin{array}{l}\text { cystenze verwijding } \\
\text { intestinale metaplasie }\end{array}$ & & 2 & 4.8 \\
\hline \multirow{3}{*}{$\mathbf{P}$} & $\begin{array}{l}\text { intestinale metapiasie } \\
\text { dysplasie }\end{array}$ & & $\begin{array}{l}6 \\
0\end{array}$ & $\begin{array}{r}14.3 \\
0.0\end{array}$ \\
\hline & & licht & 0 & $\begin{array}{l}0.0 \\
0.0\end{array}$ \\
\hline & atrofische gastritis & matig & 8 & 19.0 \\
\hline \multirow[t]{3}{*}{$U$} & zoutzuurcellen & voldoende & 34 & 81.0 \\
\hline & & verminderd & 4 & 9.5 \\
\hline & & afwezig & 4 & 9.5 \\
\hline
\end{tabular}




\subsection{Samenvatting van de onderzoekgegevens}

Uit dit onderzoek komen de wolgende gegevens naar voren:

- bij 43 symptoomloze patiënten (gemiddelde leeftijd 61.3 jaar, gemiddeld interval 22.9 jaar), endoscopisch en histologisch onderzocht in de periode 1980 tot en met 1982, meer dan 10 jaar nat een Bl-resectie, werd geen stompcarcinoom vastgesteld;

- bij histologisch onderzoek werd een matige dysplasie ter hoogte van het stoma gezien bij 4 patiènten $(9.5 \%)$;

- bij histologisch onderzoek werd een cysteuze verwijding van de klierbuizen ter hoogte van het stoma vastgesteld bij $26.2 \%$ van de patiênten. 


\section{Endoscopisch en histologisch onderzoek van BII-ma- gen, in verband met een bloeding, in de periode 1970 tot en met 1982}

Eenenvijftig patiënten met een BII-resectiemaag werden in de periode 1970 tot en met 1982 onderzocht in verband met de verschijnselen van een bloeding (bloedbraken, teerontlasting) uit het bovenste gedeelte van het maagdarmkanaal.

Van deze 51 patiënten bleken 9 mannen een stompcarcinoom te hebben. De resultaten van onderzoek van deze groep carcinoompatiënten worden apart gemeld en vergeleken met de onderzoekresultaten van de overige patiënten uit deze populatie BII-patiênten.

Van de carcinoom-en niet-carcinoompatiënten worden de gemiddelde leeftijd op het moment van onderzoek en het gemiddelde tijdsinterval vanaf de operatie met variatie en standaarddeviatie vermeld in Tabel 11.1. Dezelfde gegevens worden tevens vermeld voor de groep patiënten, onderverdeeld naar tijdsinterval meer dan 10 jaar en korter dan 10 jaar na de operatie.

Tabel 11.1. Patiènten met een BlI-maag met een bloeding, onderzocht in de periode 1970 tot en met 1982.

\begin{tabular}{|c|c|c|c|c|c|}
\hline & \multirow{2}{*}{$\begin{array}{l}\text { aantal } \\
\text { patiënten }\end{array}$} & \multicolumn{2}{|c|}{ geslacht } & \multirow{2}{*}{$\begin{array}{l}\text { gerniddelde } \\
\text { leeftijd } \\
\text { (variatie en SD) }\end{array}$} & \multirow{2}{*}{$\begin{array}{l}\text { gemiddelde } \\
\text { tijdsinterval } \\
\text { (variatic en } S D \text { ) }\end{array}$} \\
\hline & & man & vrouw & & \\
\hline patiënten totaal & 51 & 46 & 5 & $\begin{array}{l}59.6 \mathrm{jr}(36-89 \mathrm{jr} \\
\text { S.D. 13.8 jr) }\end{array}$ & $\begin{array}{l}21.3 \mathrm{jr}(1-49 \mathrm{jr} \\
\text { S.D. } 13.0 \mathrm{jr})\end{array}$ \\
\hline $\begin{array}{l}\text { patiënten met } \\
\text { carcinoom }\end{array}$ & $9(17.6 \%)$ & 9 & . & $\begin{array}{l}73.4 \mathrm{jr}(57-89 \mathrm{jr} \\
\text { S.D. } 9.2 \mathrm{jr})\end{array}$ & $\begin{array}{l}37.8 \mathrm{jr}(30-45 \mathrm{jr} \\
\text { S.D. } 4.5 \mathrm{jr})\end{array}$ \\
\hline $\begin{array}{l}\text { patiënten zonder } \\
\text { carcinoom. }\end{array}$ & $42(82.4 \%)$ & 37 & 5 & $\begin{array}{l}56.6 \mathrm{jr}(36-83 \mathrm{jr} \\
\text { S.D. } 13.1 \mathrm{jr})\end{array}$ & $\begin{array}{l}17.8 \mathrm{jr}(1.49 \mathrm{jr} \\
\text { S.D. } 11.6 \mathrm{jr})\end{array}$ \\
\hline $\begin{array}{l}\text { patiënten } \\
>10 \text { jaar post- }\end{array}$ & 38 & 35 & 3 & $\begin{array}{l}63.4 \mathrm{jr}(36-89 \mathrm{jr} \\
\text { S.D. 13.6 jr) }\end{array}$ & $\begin{array}{l}26.9 \mathrm{jr}(11-49 \mathrm{jr} \\
\text { S.D } 10.3 \mathrm{jr})\end{array}$ \\
\hline $\begin{array}{l}\text { operatiet } \\
\text { patiênten } \\
<\text { lo jaar post- } \\
\text { operatief }\end{array}$ & 13 & 11 & 2 & $\begin{array}{l}48.5 \mathrm{jr}(36-65 \mathrm{jr} \\
\text { S.D. } 8.5 \mathrm{jr})\end{array}$ & $\begin{array}{l}4.9 \mathrm{jr}(1-10 \mathrm{jr} \\
\text { S.D.2.8jr) }\end{array}$ \\
\hline
\end{tabular}

\subsection{Gegevens van de anamnese}

De indicaties voor de primaire operatie worden gegeven in Tabel 11.2.

Tabel 11.2. Indicatie voor primaire operatie van de 51 patiënten met een BII-maag

\begin{tabular}{|c|c|c|c|c|c|}
\hline & $\begin{array}{l}\text { aantal } \\
\text { patiënten }\end{array}$ & $U D$ & $U V$ & UD of UN & $\begin{array}{l}\text { andere goedandige } \\
\text { aandoening }\end{array}$ \\
\hline $\begin{array}{l}\text { patiéntern met } \\
\text { carcinoom }\end{array}$ & 9 & $5(55.6 \%)$ & $1(11.1 \%)$ & $3(33.3 \%)$ & - \\
\hline $\begin{array}{l}\text { patienten zonder } \\
\text { carcinoom }\end{array}$ & 42 & $18(42.9 \%)$ & $1(2.4 \%)$ & $19(45.2 \%)$ & $4(9.5 \%)$ \\
\hline
\end{tabular}

De anammese opnemend bleken 21 patiënten ( 15 niet-carcinoom-, 6 carcinoompatiënten), afgezien van de bloeding, klachtenvrij te zijn. De bij de overige 30 patiënten aanwezige maagdarmklachten worden weergegeven in Tabel 11.3 . 
Tabel 11.3. Klachten van 30 patiënten met een bloeding

\begin{tabular}{lcc}
\hline klachten/aantal patienten & $A B S$ & $\%$ \\
& $n=30$ & \\
\hline eetlust verminderd & 12 & 40.0 \\
vermagering & 11 & 36.7 \\
auntalkg.vermagering & 44 & 4.0 \\
zuurbranden & 8 & 26.7 \\
opboeren & 11 & 36.7 \\
misselijkheid & 9 & 30.0 \\
overgeven & 2 & 6.7 \\
pijn & 14 & 46.7 \\
druk, opgezet gevoel e.d. & 4 & 13.3 \\
\hline
\end{tabular}

* 1. patiënten vermageren in totaal $44 \mathrm{~kg}$.

$=$ gemiddeld $4.0 \mathrm{~kg}$ per vermagerde patiënt

$=$ gemiddeld $1.5 \mathrm{~kg}$ per patiënt

De anamnese werd tewens bekeken op factoren mogelijk ten grondslag liggend aan de bloeding, zoals antistollingstherapie, medicatie (analgetica, antiflogistica e.d.), alcoholabusus enz.. Tabel 1.1.4. toont potentiële oorzaken vam de bloeding bij 19 patiënten (18 niet-carcinoom-, 1 carcünoompatiënt).

Tabel 11.4.Potentiële oorzaken van de bloeding bij 19 patiënten met een BII-maag

\begin{tabular}{|c|c|c|}
\hline oorzaken bloeding/aantal patiënten & $\begin{array}{l}A B S \\
n=19\end{array}$ & $\%$ \\
\hline allcoholabusus ${ }^{\text {th }}$ & 5 & 26.3 \\
\hline salicylaten ${ }^{*}$ & 8 & 42.1 \\
\hline indomethacine & 3 & 15.8 \\
\hline antistollingstherapie & 3 & 15.8 \\
\hline morbus Rendu-Osler & 1 & 5.3 \\
\hline
\end{tabular}

: 1 patiënt alcoholabusus + gebruik salicylaten

\subsection{Gegevens van de endoscopie}

Bij 37 patienten werd bij endoscopisch onderzoek een potentiële bloedingsbron vastgesteld (zie Tabel 11.5.).

Tabel 11.5. Potentièle bloedingsbron bij endoscopie vastgesteld bij 37 patiënten met en BII-maag

\begin{tabular}{llc}
\hline bloedingsbron/anntal patienten & ABS & $\%$ \\
\hline ulcus pepticum jejuni & 10 & 27.0 \\
ulcus stoma & 6 & 16.2 \\
erosie jejunum & 2 & 5.4 \\
erosie stoma & 2 & 5.4 \\
kwetsbaar slijmvlies & 2 & 5.4 \\
carcinoom & 9 & 24.3 \\
Mallory-Weiss laesie & 1 & 2.7 \\
ulceratie oesophagus & 5 & 13.5 \\
\hline
\end{tabular}


Bij 9 carcinoompatiënten werden de volgende afwijkingen vastgesteld:

patiënt 1: $4 \mathrm{~cm}$ onder de oesophagus-maagovergang aan de voorwandzijde van het corpus hobbelig slijmm vlies met centraal spuitend vaatje, wijzend op een maligne proces;

patient 2: ter hoogte van de achterwand van het stoma minimaal nodulair slijmvlies, enigszins suspect voor een maligne proces;

patiènt 3: ter hoogte van de achterwand-grote curvatuurzijde van het stoma star weefsel, via de achterwand zich uitbreidend naar proximaal, wijzend op een maligne proces;

patiënt 4: ter hoogte van de achterwand-grote curvatuurzijde van het stoma grote en kleine noduli, wijzend op een maligne proces;

patiënt 5: ter hoogte van de kleine curvatuurzijde van het stoma, overgrijpend op voor-en achterwand nodulair *erdikt weefsel, zich uitbreidend naar proximaal váa kleine curvatuurzijde, wijzend op een maligne proces:

patiënt 6: ter hoogte van de voorwand van de stoma-praestomaregio een in de lengterichting verlopend ulcus, $3 \mathrm{~cm}$ lang, endoscopisch niet verdacht voor een maligne proces;

patiënt 7: in de praestomaregio aan de voorwandzijde een ulceratief proces, $3 \times 2 \mathrm{~cm}$, in star slijmwlies, wijzend op een maligne praces:

patiënt 8: ter hoogte van de voorwandzijde van het stoma, zich uitbreidend naar de cardia een handpalmgroot proliferatief proces, wijzend op een maligne proces;

patiënt 9" ter hoogte van het stoma diffuus spekkig slijmwlies; aan de achterwandzijde van het stoma een handpalmgroot oppervlakkig erosief gebied; ulceratieve laesie aan de kleine curvatuurzijde van het praestomagebied; knikkergroot polipoïde laesie halverwege het corpus aan de voorwandzijde, een en ander wijzend op een maligne proces.

Ten aamzien van de endoscopische beelden kan gemeld worden dat van de 9 via histologisch onderziek gediagnostiseerde carcinomen er 7 endoscopisch duidelijk waren, eenmaal minimaal nodulair slijmvlies ter hoogte van het stoma gezien werd enigszins suspect voor een maligne proces, evemeens eenmaal in de stoma-praestomaregio een ulcus gezien werd, niet verdacht voor malig-. niteit. Het carcinoom bjeek zevenmaal in de stomaregio gelocaliseerd te zijn, waarbij viermaal met uitbreiding corpuswaarts, eenmaal in de praestomaregio, terwijl eenmaal het carcinoom gediagnostiseerd werd in het proximale corpus van de restmaag (zie figuur 11.1).

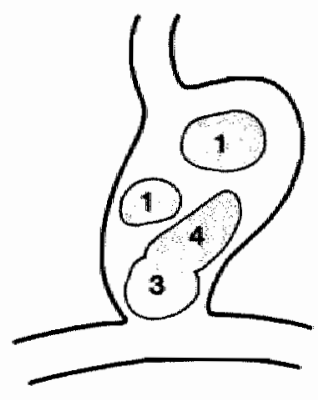

Figuur 11.1.

Localisatie van de 9 carcinomen in de BIl-mag 
De overige bevindingen bij endoscopisch onderzoek van de niet-carcinoom patiënten worden vermeld in Tabel 11.6.

Tabel 11.6.Algemene endoscopiegegevens van de 42 niet-carcinoompatiënten met een BII-maag

\begin{tabular}{|c|c|c|c|}
\hline \multicolumn{2}{|c|}{ endoscopie gegevens/dantal patienten } & \multirow{2}{*}{$\begin{array}{l}A B S \\
n=42 \\
40\end{array}$} & \multirow{2}{*}{$\begin{array}{l}\% \\
95.2\end{array}$} \\
\hline stoma & normaal & & \\
\hline & plooiconvergentie & 1 & 2.4 \\
\hline & stenose & 1 & 2.4 \\
\hline \multirow{3}{*}{ stomagastritis } & geen & 2 & 4.8 \\
\hline & matig & 15 & 35.7 \\
\hline & duidelijk & 25 & 59.5 \\
\hline \multirow[t]{3}{*}{ corpusgastritis } & geen & 14 & 33.3 \\
\hline & matig & 23 & 54.8 \\
\hline & duidellijk & 5 & 11.9 \\
\hline \multirow{4}{*}{ hoeveelheid gal } & onbekend & 32 & 76.2 \\
\hline & geen & 3 & 7.1 \\
\hline & matig & 5 & 11.9 \\
\hline & weel & 2 & 4.8 \\
\hline
\end{tabular}

\subsection{Gegevens van histologisch onderzoek}

Van de 9 patiënten met een carcinoom in de geopereerde maag, werd de diagnose zevenmaal gesteld vila histologisch onderzoek van bij endoscopie genomen biopten. Eenmaal werden bij histologisch onderzoek voor maligniteit verdachte cellen in het biopt gezien, de diagnose carcinoom werd bevestigd bij obductie van de patiënt; eenmaal werd in verband met een heftige bloeding (spuitend vat) niet gebiopteerd, de diagnose carcinoom werd bevestigd via histologisch onderzoek van het resectiepreparaat.

Van de 9 carcinomen bleken 7 carcinomen van het intestinalle type, 2 carcinomen van het diffuse type te zijn. Bij I patiënt was een dubbeltumor aanwezig: een carcinoom van het intestinale type en een maligne carcinoï. De overige histologische bevindingen bij deze 9 patiënten worden vermeld in Tabel 11.7. Van deze patienten konden 6 stoma- en 7 corpusbiopten goed worden beoordeeld.

Ten aanzien van het fenomeen matige dysplasie ter hoogte van het stoma, kan nog opgemerkt worden, dat bij de 9 carcinoompatienten ter hoogte van het stoma tweemaal een matige dysplasie aanwezig bleek, tweemaal een lichte clysplasie. Tweemaal werd geen dysplasie vastgesteld, bij 3 patienten bestond het stomabiopt alleen uit carcinoomnweefsel. 
Tabel 11.7. Gegevens van histologisch onderzoek wan de 9 carcinoompatiênten mer een BII-malg (6 stoma- en 7 corpusbiopsiezin)

\begin{tabular}{|c|c|c|c|c|}
\hline \multicolumn{3}{|c|}{ histologische gegevens/aantal patienten } & \multirow{2}{*}{$\begin{array}{l}A B S \\
n=6 / 7 \\
4\end{array}$} & \multirow{2}{*}{$\frac{6}{66.7}$} \\
\hline $\mathrm{s}$ & slijmvlieskarakter stoma & antrum & & \\
\hline & & corpus & 2 & 33.3 \\
\hline \multirow{4}{*}{$T$} & & antrumicorpus & 0 & 0.0 \\
\hline & ontsteking stoma & geen & 1 & 16.7 \\
\hline & & focaal & 2 & 33.3 \\
\hline & & diffuus & 3 & 50.0 \\
\hline \multirow[t]{3}{*}{ O } & ontsteking stoma & geen & 1 & 16.7 \\
\hline & & licht & 3 & 50.0 \\
\hline & & matig & 2 & 33.3 \\
\hline \multirow[t]{3}{*}{ M } & & ernstig & 0 & 0.0 \\
\hline & cysteuze verwijding. & & 4 & 66.7 \\
\hline & intestinale metaplasie & & 2 & 33.3 \\
\hline \multirow[t]{2}{*}{ A } & dysplasie & licht & 0 & 0.0 \\
\hline & & matig & 2 & 33.3 \\
\hline \multirow[t]{3}{*}{$\mathrm{C}$} & ontste king corpus & geen & 0 & 0.0 \\
\hline & & focaal & 1 & 14.3 \\
\hline & & diffuus & 6 & 85.7 \\
\hline \multirow[t]{3}{*}{$\mathrm{O}$} & ontsteking corpus & geen & 0 & 0.0 \\
\hline & & licht & 6 & 85.7 \\
\hline & & matig & 1 & 14.3 \\
\hline \multirow[t]{3}{*}{$\mathbf{R}$} & & ernstig & 0 & 0.0 \\
\hline & cysteuze verwijding & & 3 & 42.8 \\
\hline & intestinale metaplasie & & 4 & 57.1 \\
\hline \multirow[t]{3}{*}{$\mathrm{P}$} & dysplasie & licht & 3 & 42.8 \\
\hline & & matig & 1 & 14.3 \\
\hline & atrofische gastritis & & 1 & 14.3 \\
\hline \multirow[t]{3}{*}{$\mathrm{U}$} & zoutzuurcellen & voldoende & 3 & 42.8 \\
\hline & & verminderd & 4 & 57.1 \\
\hline & & afwezig & 0 & 0.0 \\
\hline $\mathrm{S}$ & & & & \\
\hline
\end{tabular}

Van de 42 niet-carcinoompatiënten werd bij 8 patiënten in verband met een ernstige bloeding. bioptisch geen materiaal voor histologisch onderzoek genomen.

De gegewens van histologisch onderzoek van de stomabiopsieën van 34 patiënten en corpusbiopsieën van 33 patiënten (van een patiënt bleken de corpusbiopsieën zoekgeraakt te zijn), worden. gemeld in Tabel 11.8 .

In de stomabiopten van 34 niet-carcinoompatiënten werd geen matige dysplasie gevonden, 14 mal bleek een lichte dysplasie aanwezig te zijn. 
Tabel 11.8. Gegevens wan histologisch onderzoek van de 34 niet-carcinoompatiënten met een BII-maag ( 34 stoma en 33 corpusbiopten)

\begin{tabular}{|c|c|c|c|c|}
\hline hist & tologische gegevens/antat & Enten & $\begin{array}{l}A B S \\
\pi=3\end{array}$ & $\%$ \\
\hline $\mathrm{s}$ & slijmvliesikarakter stoma & antrum & 15 & 44.1 \\
\hline & & corpus & 18 & 52.9 \\
\hline & & antrum/corpus & 1 & 3.0 \\
\hline $\mathrm{T}$ & ontstekingstoma & geen & 2 & 5.9 \\
\hline & & focdal & 1 & 3.0 \\
\hline & & diffuns & 31 & 91.1 \\
\hline 0 & ontsteking stoma & geen & 2 & 5.9 \\
\hline & & licht & 7 & 20.6 \\
\hline & & matig & 23 & 67.6 \\
\hline M & & emstig & 2 & 5.9 \\
\hline & cysteuze werwijding & & 27 & 79.4 \\
\hline & intestinale metaplasic & & 6 & 17.6 \\
\hline A & dysplasie & licht & 14 & 41.2 \\
\hline & & matig & 0 & 0.0 \\
\hline $\mathrm{C}$ & ontsteking corpus & geen & 11 & 33.3 \\
\hline & & focaal & 5 & 15.2 \\
\hline & & diffuus & 17 & 51.5 \\
\hline 0 & ontsteking corpus & geen & 11 & 33.3 \\
\hline & & licht & 14 & 42.4 \\
\hline & & matig & 8 & 24.3 \\
\hline $\mathrm{R}$ & & ernstig & 0 & 0.0 \\
\hline & cysteuze verwijding & & 2 & 6.1 \\
\hline & intestinale metaplasie & & 1 & 3.0 \\
\hline$P$ & dysplasie & licht & 0 & 0.0 \\
\hline & & matigg & 0 & 0.0 \\
\hline & atrofische gastritis & & 4 & 12.1 \\
\hline U & zoutzuurcellen & voldoende & 27 & 81.8 \\
\hline & & verminderd & 5 & 15.2 \\
\hline & & afwezig & 1 & 3.0 \\
\hline
\end{tabular}

\subsection{Ziektegeschiedenis van de carcinoompatiënten}

patiĕnt 1: man, geboren in 1891 ; BII-resectie in verband met ulcuslijden (ulcus duodeni?, ukus ventriculi?). Bloeding in maart 1980 bij corticosteroidtherapie in verband met chronisch longlijden. Er bestonden enkele weken klachten over verminderde eetlust, gering gewichtsverlies, ietwat opboeren. Gastroscopie: middelgrote BII-resectimaag, ter hoogte van distale oesophagus en proximale maag veel oud en wers bloed; fraai stoma zonder bijzonderheden; ongeveer $4 \mathrm{~cm}$ onder de oesophagus-maagovergang aan de voorwandzijde van corpus hobbelig slijnvlies met centraal spuitend vaatie, wijzend op malligne proces. Biopten werden niet genomen in verband met heftige bloeding. Asngezien de bloeding niet tot staan kwam, volgde een operatie; ter hoogte wan de kleine curvatuurzijde bestond een geinfiltreerd gebied, reikend van distaal van de cardia tot enkele centimeters proximaall van het stoma; een wig-resectie werd verricht. Histologisch onderzoek wees op het bestaan van een carcinoom van het intestinale type, met doorgroei tot in thet vetweefsel, in zenuwen/bloedwaten; lymfkliermetastasen waren aanwezig. Ongeveer 14 dagen na de operatie is patiënt acuut overleden. Bij obductie werd een $90 \%$ stenose van de coronairvaten gezien; tussen maagrest en lever bevond zich een holte gevuld met necrotisch materiaal, geen verbinding tonend met de restmaag.

patiënt 2: man, geboren in 1924; BIl-resectie in 1942 in verband met perforatie ulcus duodeni. Bloeding in april 1981 bij antistollingstherapie. Enkele dagen klachten over verninderde eetlust, gevoelens van misselijkheid. Gastroscopie: middelgrote BII-resectiemalag; ter hoogte van achterwand stoma minimaal nodulair slijimwlies, enigszins suspect voor maligniteit; ulceratieve laesie niet aanwezig; het corpus van de maag toonde geen bijzonderheden. Histologisch onderzoek wees op het bestaan van een carcinoom wan het intestinale type. Operatie: subtotale maagresectie met RouxY-anastomose. Macroscopisch toonde het resectiepreparaat geen duidelijke afwijkingen, histologisch werd een carcinoom van het intestinale type ter hoogte wan het stoma gezien "met begin 
van invasieve groei; diverse coupes wan het stoma toonden dysplasie, varierend van licht tot matig. Het postoperatieve tijdvak werd gecompliceerd door een longinfectie en cerebrow wasculair accident. In februari 1983 bevond patient zich in goede algemene conditie.

patient 3: man, geboren in 1910; BLI-resectie in verband met ulcus duodeni. Bloeding in juni 1979 bij klachtenvrije patiënt. Gastroscopie: middelgrote BII-resectiemaag; ter hoogte van de achterwandgrote curvaturzijde stoma star weefsel, via achterwand tich uitbreidend naar proximaal, wijzend op een maligne proces; corpus overigens matig geinjiceerd slijmvlies. Histologisch onderzoek wees op het bestaan van een carcinoom van het diffuse type. Operatie: mandarijngrote mobiele tumor ter hoogte van stoma; subtotale maagresectie met Roux-Y-anastomose; geen metastasen. Histologisch onderzoek toonde een carcinoom van het diffuse type met doorgroei in de serosa, tevens perineurale en angio-invasieve groei. Postoperatief hebben er zich geen problemen voorgedaan. In verband met klachten over verminderde eetlust, opboeren, gevoelens van misselijkheid en overgeven volgde een gastroscopie in januari 1980: status na subtotale matgresectie: hobbelig, geinfiltreerd slijmvlies ter hoogte van overgang maagrest-dundarmlis. Histologisch onderzoek wees op het bestaan van een carcinoom van het diffuse type. Operatie volgde waarbij tu* mordoorgroe in de dunne darm en buikwand werd gezien. In maart 1980 is patiênt overleden.

patiënt 4: man, geboren in 1904; BII-resectie in 1942 in verband met ulcuslijden (ulcus duodeni?, ulcus ventriculi?). Bloeding in maart 1976 bij klachtenvrije patiênt. Gastroscopie: middelgrote Bll-resectiemaag; ter hoogte van achterwand-grote curvatuurzijde stoma grotere en kleinere noduli, wijzend op een maligne proces; corpus van de maag toonde een matig geinjiceerd slijmvlies. Histologisch onderzoek toonde een carcinoom van het intestinale type. Büj operatie werden veel vergroeiingen ter hoogte van bovenbuik gezien; de restmaag was over het gehele oppervlak geinfiltreerd, er was doorgroei naar de omgeving; aangezien het carcinoom inoperabel bleek, werd een gastro-enterostomie met Braunse anastomose aangelegd. Ongeveer een week ma operatie is patiënt acuut overleden: longembolie?? Obductie heeft niet plaatsgevonden.

patiënt 5: man, geboren in 1908; BII-resectie in 1942 in verband met ullcus duodeni. Maagbloeding in maart 1977 bij klachtenvrije patiënt. Gastroscopie: middelgrote BII-resectiemaag; ter hoogte van kleine curvatuurzijde stoma, overgrijpend op woor-en achterwand nodulair verdikt weefsel, via klleine curvatuurzijde zich uitbreidend naar proximaal, wijzend op een maligne proces; corpus overigens niet duidelijk afwijkend. Histologisch onderzoek wees op het bestaan van een carcinoom van het intestinale type. Bij operatie werd ter hoogte van de restmaag een groot carcinoom gevoeld; de restmaag en een stuk jejunum werden en-block verwijderd; aangezien bij vriescoupe het proximale resectievlak niet wrij van tumor bleek, werd de distale oesophagus verwijderd, een oesophago-jejunostomie end to side werd aangelegd. Het maagresectiepreparaat toonde een geinfiltreerd stoma met uitbreiding proximaalwaarts; het corpus toonde aan de kleine curvatuurachterwandzijde een $5 \mathrm{~cm}$ grote tumot met ulceratie tot in de serosa. Histologisch bleek een dubbel-tumor aanwezig: ter hoogte van het stoma een carcinoom van het intestinale type, elders een maligne carcinoild. Postoperatief hebben er zich geen problemen woorgedaan. In juli 1978 volgde een opname in verband met een flegmoneuze appendicitis; metastasen werden bij operatie niet gezien. In maart 1979 is patiënt cachectisch overleden. Een obductie werd niet verricht.

patiênt 6: mar, geboren in 1912; BII-resectie in 1940 in verband met ulcus duodeni. Sedert de operatie in 1940 heeft patiënt tot 197613 maal een maagbloeding gehad. Maagklachten zijn overigens nooit aanwezig geweest. In verband met een bloeding in ok tober 1980 werd een gastroscopie verricht: middelgrote BII-resectiemaag; geringe hoeveelheid gal aanwezig; ter hoogte van voorwand stoma-praestomaregio in lengterichting verlopend ulcus, $3 \mathrm{~cm}$ lang, niet werdacht voor een maligne proces; corpus van de maag toonde licht geinjiceerd slijmvlies. Histologisch onderzoek wees op het bestaan van een carcinoom van het intestinale type. Operatie: subtotale maagresectie met Roux-Y-anastomose. Het maagresectiepreparaat toonde een klein ulceratief defect ter hoogte van het stoma, in doorsnee bestaand uit wit-grijzig weefsel, reikend tot in de muscularis. Histologisch onderzoek toonde een carcinoom van het intestinale type, infiltratief groeiend tot aan de tunica muscularis. Lymfkliermetastasen waren niet aanwezig. Postoperatief hebben er zich geen problemen woorgedaan. In januari 1981 volgde een opname voor een liesbreukoperatie. In febru* ari 1983 bevond patiënt zich in een goede algemene conditie.

patiënt 7: man, geboren in 1901; BII-resectie in 1940 in verband met ulcus duodeni. Bloeding in januari 1981 bij klachtenwrije patient. Gastroscopie: middelgrote BII-resectiemaag, fra ai stoma zonder bijzonderheden, in praestomaregio aan voorwandzijde ulceratief proces $3 \times 2 \mathrm{~cm}$ groot, in star slijmvlies, wijzend op maligne proces; het corpus toonde geen bijzonderheden. Histologisch onderzoek wees op een carcinoom vam het diffuse type. De behandelend internist wees een operatic af in verband met patient's leeftijd. In verband met een recidief bloeding werd patiênt opnieuw in het ziekenhuis opgenomen in oktober 1982. Er bestonden klachten over verminderde eetlust, ge. ringe vermagering, pijnen in epigastrio. Gastroscopie: middelgrote BII-resectiemaag, geen gal ter hoogte van restmaag; stoma- en praestomaregio bleken over een afstand van $3 \mathrm{~cm}$ geinfil- 
treerd te zijn, ter hoogte van grote en kleine curvatuurzijde bevonden zich oppervlakkig ulceratheve laesies, 1 tot $1.5 \mathrm{~cm}$ in doorsnee; het corpus van de maag toonde een licht tot mathig geinjiceerd slijmwlits. Gezien lleeftijd en matig algemene conditie werd afgezien van operatie In februar 1 1983. was er sprake van verdere achteruitgang in algemene conditie.

patiënt 8: man, geboren in 1899", BII-resectic in 1937 in verband met ulcuslijden (uIcus duodeni?, ulcus ventriculi?). Bloeding in februari 1977 bij vermagering van $6 \mathrm{~kg}$ in 2 tot 3 maanden, overigens geen maagklachten. Gastroscopie: middelgrote Bll-resectiemaag; ter hoogte van woonwandzijde stoma, zich uitbreidend naar de cardia handpalmgroot proliferatief proces, wijzend op malligniteit; corpus overigens een matig geinjiceeerd slijmvlies. Histologisch onderzoek van bij herhaling genomen biopten toonde een ulcererend en gramulerend proces, voor maligniteit verdachte cellen. In verband met de leeftijd en uitgebreidheid van het proces werd van operatie afgezien. Patiënt is overleden in augustus 1978. Bij obductie werd een groot $(4 \times 4 \mathrm{~cm})$ onregelmatig begrensd ulcus met opgeworpen rand gezien, wanaf het stoma zich uitbreidend naar proximaal. Histologisch onderzoek wees op het bestaan van een carcinoom van het intestinale type; in de linker boven$k$ wabsbronchus werd een weede carcinoom gezien, histologisch een $k$ keincellig anaplastisch carcinoom.

patiënt 9: man, geboren in 1900; BII-resectie in 1942 in verband met ulcus ventriculi. Bloeding in april 1979 bij klachtenvrije patiênt. Gastroscopie: middelgrote BII-resectiemaag; ter hoogte van stoma diffuus spekkig slijmvlies, aan achterwandzijde handpalmgroot oppervlakkig erosief gebied; ulceratieve laesie ter hoogte van k leine curvatuurzijde praestomaregio; knikkergrote polipoide laesie halverwege corpus voorwandzijde; een en ander wijzend op maligne proces. Histologisch onderzoek wees op het bestaan van een carcinoom wan het intestinale type. Bij operatie werd een tumor gezien, doorgroeiend tot in de leverhilus; de tumor kon worden verwijderd. Het resectieprepatraat toonde een turnor, $11 \times 6 \mathrm{~cm}$ groot, door de spierlaag heen groeiend, gelocaliseerd in sto ma en corpus van de restmaag; histologisch onderzoek toonde een carcinoom van het intestinale type met angio-invasieve groei, groei in lymispleten en zenuwen. Postoperatief hebben er zich geen problemen woorgedlan. Patient is overleden in augustus 1979 . Obductie werd niet verricht.

\subsection{Samenvatting van de onderzoekgegevens}

Bij dit onderzoek komen de volgende gegevens natar voren:

- bij 51 patiënten (gemiddelde leeftijd 59.6 jaar, gemiddeld interval 21.3 jaar) met een maagbloeding, endoscopisch en histologisch onderzocht in de periode 1970 tot en met 1982,1 tot 49 jaar na een Bll-resectie, werd bij 9 patiënten (gemiddelde leeftijd 73.4 jaar, gemiddeld interval 37.8 jaar) histologisch een carcinoom vastgesteld (zeven maal van het intestinale type, tweemaal van het diffuse type;

van de 9 carcinoompatiënten bleken 6 patiẻnten afgezien van de bloeding klachtenvrij te zijn, van de 42 niet-carcinoompatiënten bleek dit bij 1.5 patiënten het geval te zijn;

- van 18 niet-carcinoompatiënten ( $42.8 \%$ ) bleek de anamnese positief ten aanzien'van cen eventucle oorzaak voor de bloeding, van 9 carcinoompatiënten bleek dit slechts bij $\mathbb{1}$ patiënt (11. $1 \%$ ) het geval te zijn;

- bij de 9 carcinoompatiënten bleek ter hoogte van het stoma slechts tweemaal een matige dysplasie aanwezig. waarbij opgemerkt dat het stoma hierop bij 3 patiënten niet te beoordelen bleek te zijin;

- ondanks het feit, dat 6 patiënten klachtenvrij waren op het moment van de bloeding, bleken binnen 2 jaar 4 van deze patiënten (driemaal operatie, eenmaal geen operatie) overleden te zijn aan de gevolgen van het maagcarcinoom;

- bij geen van de 34 niet-carcinoompatiënten, bij wie histologisch onderzoek van het stoma werd vericht, werd een matige dysplasie aangetroffen; ten dele kan dit verklaard worden door het geringe aantal stomabiopten van een aantal patiënten uit de periode 1970 tot en met 1979 ;

- zeer frequent werd ter hoogte van het stoma histologisch een cysteuze verwijding van de klierbuizen gezien ( $79.4 \%$ ), hetgeen opgevat kan worden als een kenmerkende afwijkende bevinding van het stomaslijmulies. 


\section{Hoofdstuk 12}

\section{Discussie}

In de volgende bespreking, gebaseerd op gegevens van literatuuronderzoek en de resultaten van eigen onderzoek komen de volgende punten aan de orde:

1 : de definitie van het stompcarcinoom;

2 : de frequentie van voorkomen van het stompcarcinoom na een BI-en Bll-resectie;

3a: vergelijking van endoscopische en histologische beelden van niet-carcinoompatiënten met een BI-resectiemaag, meur dan 10 jaar postoperatief, onderscheiden naar het all of niet aanwezig zijn van klachten, onderzocht in de periode 1980 tot en met 1982 ;

3b: vergelijking van endoscopische en histologische beelden van niet-carcinoompatiënten met een Bll-resectiemaag, meer dan 10 jaar postoperatief, onderscheiden naar het al of niet aanwezig zijn van klachten, onderzocht in de periode 1980 tot en met 1982;

4a: vergelijking van de frequentie van voorkomen van het stompcarcinoom en de prognose van het stompcarcinoom van patiënten met een BI-resectiemaag, meer dan 10 jaar postoperatief, onderscheiden naar het al of niet aanwezig zijn van klachten, onderzocht in de periode 1970 tot en met 1982 ;

$4 \mathrm{~b}$ : vergelijking wan de frequentie van woorkomen van het stompcarcinoom en de prognose van het stompcarcinoom van patiënten met een BII-resectiemaag, meer dan 10 jaar postoperatief, onderscheiden naar het al of niet aanwezig zijn van klachten, onderzocht in de periode 1970 tot en met 1982

5a: vergelijking van gegevens van patiënten met een BI-en BII-resectiemaag, meer dan 10 jaar postoperatief, onderzocht in verband met klachten in de periode 1970 tot en met 1979 (groep A);

5b: vergelijking van gegevens van patiënten met een BI- en BII-resectiemaag, meer dan 10 jaar postoperatief, onderzocht in verband met klachten in de periode 1980 tot en met 1982 (groep B);

5c: vergelijking van gegevens van symptoomloze patiënten met een BI-en Bll-resectiemaag, meer dan 10 jaar postoperatief, onderzocht op het voorkomen van een stompcarcinoom in de periode 1980 tot en met 1982 (groep C);

6 : de betekenis van het symptoom bloeding als late postoperatieve complicatie bij patienten met een BII-resectiemaag, onderzocht in de periode 1970 tot en met 1982 ;

7 : de betekenis van het histologische fenomeen matige dy splasie als eventueel premaligne kenmerk van het stompcarcinoom;

8 : de betekenis van endoscopisch en histologisch onderzock van symptoomloze patiënten met een BI- en BIll-resectiemaag, meer dan 10 jaar postoperalief;

9 : selectie van patiënten met een resectiemaag, in aannerking komend voor onderzoek op het voorkomen van een stompcarcinoom.

\section{ad. 1. De definitie van het stompcarcinoom}

In de literatuur wordt onder een stompcarcinoom van de BI-en BII-resecticmaag verstaan ieder carcinoom, waar ook in de restmaag gelocaliseerd, meer dan 5 jaar na de primaire operatie, die verricht werd in verband met een histologisch bewezen goedaardige aandoening. Waar ten aanzien van de pathogenetische mechanismen vanuil dierexperimenteel onderzoek en klinische studies weliswaar niet bewezen, echter aannemelijk gemaakt is, dat de gallige reflux een belangrijke rol speelt in de ontstaansgeschiedenis van het carcinoom van het stoma wan de geopereerde maag, lijkt het zinvol onderscheid te maken tussen carcinomen van de restmaag gelocaliseerd ter hoogte van het stoma en elders gelocaliseerde carcinomen, met name ter hoogte van het proximale corpus en de cardia. De stomacarcinomen kunnen worden beschouwd als te zijn ontstaan als gevolg van slijmvliesveranderingen in relatie met het lenomeen gallige reflux, wat in verband te brengen is met de procedure van de primaire operatie. De elders in de restmaag gelocaliseerde carcinomen zouden dan onder te brengen zijn bij de groep "gewone maagcarcinomen", in ieder geval wat betreft de ontstaanswijze niet in verband te brengen met het fenomeen gallige reflux. Onder de aanname, dat het stompcarcinoom frequent gezien wordt als late complicatie van de 
BIl-resectie en de galreflux een belangrijke rol speelt in de pathogenese van dit carcinoom ter hoogte van het stoma gelocaliseerd, wordt in de literatuur ten aanzien van de therapie van het peptisch ulcuslijden het volgend advies gegeven: conservatieve therapie met geneesmiddelen zoals de histamine II receptorantagonisten, dan wel chirurgische therapie in de zin van een highly selective vagotomy of eventueel een resectie volgens een galreflux verhinderende procedure.

De vraag komt naar voren, in hoeverre er klinisch verschillen bestaan tussen het ter hoogte van het stoma aanwezige carcinoom en het carcinoom gelocaliseerd elders in de restmaag. In het voorliggende onderzoek werden 48 carcinomen in een BI-resectiemaag, 2 carcinomen in een BI-resectiemaag gediagnostiseerd, meer dan 10 jaar na een primaire operatie in verband met een goedaardige aandoening. Van deze 48 carcinomen waren er 20 ter hoogte van het stoma aanwezig, 18 ter hoogte van het stoma en corpus, terwijl 10 carcinomen ter hoogte van het corpus werden wastgesteld (zie figuur 12.1). De gemiddelde leeftijd van de patiënten bedraagt in de groepen stoma-, stoma/corpus- en corpuscarcinoom achtereenvolgens 69.2,67.4 en 68.8 jaar, terwijl het gemiddelde interval berekend werd op $34.5,33.3$ en 29.4 jaar. Ter hoogte van het stoma werd 16 maal een carcinoom van het intestinale type, viermaal van het diffuse type gezien; carcinomen ter hoogte van het stoma en corpus blijken 14 maal van het intestinale type, viermaal van het diffuse type, terwijl de corpuscarcinomen histologisch zevenmaal een intestinaal type, driemaal een diffuus type laten zien.

Ook ten aanzien van het klachtenpatroon, de endoscopische en histologische beelden bestaan er tussen carcinomen van verschillende localisatie geen duidelijke verschillen.

Het heeft derhalve geen praktische consequenties carcinomen in de resectiemaag naar Jocalisatie te ondlerscheiden.

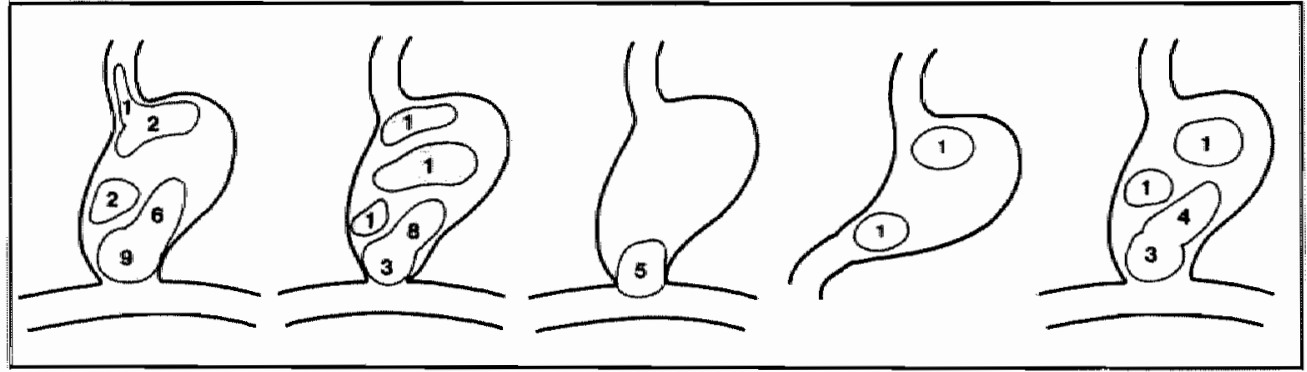

Figuur 12.1.

BII-magen met klachten 1970 tot en met 1979; BII-magen met klachten 1980 tot en met 1982; BII-magen zonder klachten 1980 tot en met 1982; BI-magen met klachten 1970 tot en met 1979; BII-magen met bloeding 1970 tot en met 1982.

\section{ad, 2. De frequentie van voorkomen van het stompcarcinoom na een BI-en BII-resectie}

De frequentie van voorkomen van het carcinoom in de BI- en BII-restmaag wordt in de literatuur zeer wisselend opgegeven, varieert van 0.0 tot $17.6 \%$, afhankellik van de katerogie onderzochte patienten. Meestal worden resultaten gemeld uit obductiestatistieken, klinisch retrospektief onderzoek en endoscopisch retrospektief onderzoek. Een enkele maal worden frequenties van voorkomen van het carcinoom vermeld vanuit prospektief endoscopisch onderzoek, waarbij onderzoek verricht wordt in wisselende tijdsintervallen vanaf de operatie, waarbij de uitval van patiënten aanzienlijk is door overlijden en weigering het endoscopisch onderzoek te ondergaan.

Aangezien in het algemeen aan de voorwaarden, die gesteld kunnen worden aan prospektief onderzoek, niet wordt voldaan, zijn er nauwelijks betrouwbare gegevens over de frequentie van voorkomen van het carcinoom in de restmaag aanwezig.

Door gebrek aan essentiële gegevens van de populatie patiënten, die in het verleden in de regio Maastricht een maagresectie heeft ondergaan, is het niet mogelijk gebleken van deze patiënten een frequentie van voorkomen van het stompcarcinoom te berekenen.

Vanuit de series endoscopisch en histologisch bestudeerde patiënten met een BI- en BII-resectiemagg, meer dan 10 jaar postoperatief, werden de frequenties van voorkomen van de carcinomen berekend:

- 292 patiënten met een BII-resectiemaag, meer dan 10 jaar postoperatief, bestudeerd in verband met klachten in de periode 1970 tot en met 1982: 34 stompcarcinomen $=11.6 \%$.

- 138 symptoomloze patiënten met een BII-resectiemaag, meer dan 10 jaar postoperatief onderzocht op het voorkomen van een stompcarcinoom in de periode 1980 tot en met 1982: 5 stompcarcinomen $=3.6 \%$. 
- 38 patiënten met een BII-maagresectie, meer dan 10 jaar postoperatief, bestudeerd in verband met een magbloeding in de periode 1970 tot en met $1982: 9$ stompcarcinomen $=23.7 \%$.

- 106 patiënten met een BI-magresectie, meer dan 10 jaar postoperatief in verband met klachten bestudeerd in de periode 1970 tot en met $1982: 2$ stompcarcinomen $=1.9 \%$.

- 43 symptoomloze patiënten met een BI-maagresectie, meer dan 10 jaar postoperatief, onderzocht op het voorkomen van een stompcarcinoom in de periode 1980 tot en met 1982: geen stompcarcinomen $=0.0 \%$.

Bij een totaal aantal van 468 patienten met een BII-resectie, meer dan 10 jaar postoperatief, werden 48 patienten gezien met een stompcarcinoom $=10.3 \%$.

Bij een totaal aantal van 149 patiënten met een BI-resectie, meer dan 10 jaar postoperatief, werden 2 patiènten gezien met een stompcarcinoom $=1.3 \%$.

ad. 3a. Vergeliking van endoscopische en histologische beelden van niet-carcinoompatiënten met een BI-resectiemaag, meer dan 10 jaar postoperatiet, onderscheiden naar het al of niet aanwezig zijn wan klachten, onderzocht in de periode 1980 tot en met 1982

Wanneer groepen niet-carcinoompatiënten met een BI-resectiemaag, meer dan 10 jaar postoperatief, onderscheiden naar het al dan niet aanwezig zijn van klachten, vergeleken worden ten aanzien van endoscopische en histologische beelden, komen voor deze vergelijking in aanmerking de groep niet-carcinoompatiënten met een BI-resectiemaag met klachten uit de periode 1980 tot en met 1982 en de groep niet-carcinoompatiënten met een BI-resectiemaag zonder klachten uit de periode 1980 tot en met 1982 . In deze periode werden volgens protocol endoscom pische beelden beoordeeld, woor histologisch onderzoek tenminste 4 biopten ter hoogte van het stoma en 4 biopten ter hoogte van het corpus van de restmaag genomen. In de periode 1970 tot en met 1979 is dit niet het geval geweest.

De algemene gegevens van endoscopisch onderzoek van de groepen niet-carcinoompatiënten met een BI-resectiemaag met en zonder klachten worden vermeld in Tabel 12.1 .

Tabel 12.1. Algemene endoscopiegegevens van de 49 patiënten met cen BI maag met klachten en de 43 patiënten met een BI-maag zonder klachten

\begin{tabular}{|c|c|c|c|}
\hline \multicolumn{2}{|c|}{ endoscopische gegevens/aantal patiënten } & \multirow{2}{*}{$\begin{array}{l}\text { met klachren } \\
\% \\
n=49 \\
98.0\end{array}$} & \multirow{2}{*}{$\begin{array}{l}\text { Zonder klachten } \\
\% \% \\
n=43 \\
97.7\end{array}$} \\
\hline stoma & normaal & & \\
\hline & plooiconvergentie & 2.0 & 2.3 \\
\hline & stenose & 0.0 & 0.0 \\
\hline \multirow{3}{*}{ stomagastritis } & geen & 4.1 & 11.6 \\
\hline & matig & 55.1 & 51.2 \\
\hline & duidelijk & 40.8 & 37.2 \\
\hline \multirow[t]{3}{*}{ corpusgastritis } & geen & 36.7 & 37.2 \\
\hline & matig & 51.0 & 53.5 \\
\hline & duidelijk & 12.3 & 9.3 \\
\hline \multirow{3}{*}{ hoeveellheid gal } & geen & 49.0 & 53.5 \\
\hline & matig & 38.8 & 27.9 \\
\hline & duidelijk & 12.3 & 18.6 \\
\hline suspect stoma & & 2.0 & 0.0 \\
\hline
\end{tabular}

Opvallende verschillen worden niet gezien ten aanzien van de configuratie van het stoma, de frequentie en ernst van de stoma- en corpusgastritis, de hoeveelheid gal ter hoogte wan de resectiemaag.

Bij vergelijking van de bijzonderheden, naar voren gekomen bij endoscopisch onderzoek (zie Tabel 12.2.) is het enig significante verschil het aantal ulceratieve/erosieve laesies: bij de symptomatische groep voorkomend in $16.3 \%$, bij de symptoomloze groep in slechts $2.3 \%$ van de gevallen $(p<0.05)$.

Deze gegevens zijn in overeenstemming met het al of niet aanwezig zijn van klachten bij deze groepen patiënten. 
Tabel 12.2. Bijzondere endoxcopische bewindingen bij de 49 patiënten met een BI-maag met klachten en de 43 patienten met een BI-madg zonder klachten

\begin{tabular}{|c|c|c|}
\hline endoscopie gegevens/aantal patienten & $\begin{array}{l}\text { met klachen } \\
\% \\
n=49\end{array}$ & $\begin{array}{l}\text { zonderklachten } \\
\% \\
n=43\end{array}$ \\
\hline forse plooien stoma & 12.2 & 4.6 \\
\hline witte plekken stoma/corpus & 6.1 & 7.0 \\
\hline ulcus duodeni & 8.2 & 0.0 \\
\hline ulcus stoma & 16.3 & $2.3^{* * *}$ \\
\hline ulcus praestoma & 2.0 & 0.0 \\
\hline erosie duodenum/stoma. & $4.1]$ & 0.0 \\
\hline kwetsbaar slijmulies & .0 & 4.6 \\
\hline suspect gebied praestoma & 20 & 0.0 \\
\hline xantelasmata & 8.2 & 9.3 \\
\hline poliepen & 2.0 & 4.6 \\
\hline
\end{tabular}

*** $\mathrm{p}<0.05$ chil-kwadraattoets

Histologisch (zie Tabel 12.3.) wordt een cysteuze verwijding van klierbuizen ter hoogte van het stoma significant vaker gezien bij patiënten met klachten $(p<0.05)$. Een lichte ontsteking van het corpus komt significant vaker voor bij patiênten met klachten $(p<0.01)$, terwijl een matig ernstige ontsteking van het corpus significant vaker gezien wordit bij patiënten zonder klachten $(p<0.05)$. Overigens bestaan er geen significante verschillen op histologisch niveau tussen deze patiënten met en zonder klachten.

Concluderend kan gesteld worden dat er geen duidelijke relatie is tussen deze ontsteking en het klachtenpatroon van de patiënt. De vraag komt naar voren of bij een aantal patiënten klachten mogen worden geinterpreteerd als veroorzaakt door een maagafwijking.

Tabel 12.3. Gegevens van histologisch onderzoek van de 49 patiënten met een BI-maag met klachten ( 47 stoma- en 46 corpusbiopsieën) en de 42 patiënten met een BI-maag zonder klachten ( 42 stoma- en 42 corpusbiopsieën)

\begin{tabular}{|c|c|c|c|c|}
\hline \multicolumn{3}{|c|}{ histologische gegeveras/aantal patiënten } & \multirow{3}{*}{$\begin{array}{l}\text { merklachiten } \\
\% \\
n=47 / 46 \\
31.9 \\
63.8\end{array}$} & \multirow{3}{*}{$\begin{array}{l}\begin{array}{l}\text { zonder klachten } \\
\% \\
n=42 \\
16.7 \\
78.6\end{array} \\
\end{array}$} \\
\hline $\mathrm{S}$ & slijmvlieskarakter stoma & antrum & & \\
\hline & & corpus & & \\
\hline & & antrum/corpus & 43 & 4.7 \\
\hline \multirow[t]{3}{*}{$\mathrm{T}$} & ontsteking stoma & geen & 19.1 & 14.3 \\
\hline & & focall & 10.6 & 26.2 \\
\hline & & diffuus & 70.3 & 59.5 \\
\hline \multirow[t]{3}{*}{0} & ontsteking stoma & geen & 19.1 & 44.3 \\
\hline & & hicht & 38.4 & 31.0 \\
\hline & & matig. & 40.4 & 47.6 \\
\hline \multirow[t]{3}{*}{ M } & & ernstig & 2.1 & 7.1 \\
\hline & cysteuze verwijding & & 48.9 & $26.2 * * *$ \\
\hline & intestinale metaplasie & & 23.4 & 21.4 \\
\hline \multirow[t]{2}{*}{ A } & dysplasie & لichti & 36.2 & 33.3 \\
\hline & & matig & 2.1 & 9.5 \\
\hline \multirow[t]{3}{*}{$\mathrm{C}$} & ontsteking corpus & geen & 28.3 & 38.1 \\
\hline & & focaal & 17.4 & 23.8 \\
\hline & & diffuus & 54.3 & 38.1 \\
\hline \multirow[t]{3}{*}{0} & ontsteking corpus & geen & 28.3 & 38.1 \\
\hline & & licht & 45.7 & $11.9 *$ \\
\hline & & matig & 23.9 & $45.2^{* * * *}$ \\
\hline \multirow[t]{3}{*}{ R } & & ermstig & 2.1 & 4.8 \\
\hline & cysteuze werwijding & & 6.5 & 4.8 \\
\hline & intestinale metaplasie & & 8.7 & 14,3 \\
\hline \multirow[t]{3}{*}{$\mathbf{P}$} & dysplasie & licht & 0.0 & 0.0 \\
\hline & & matig & 0.0 & 0.0 \\
\hline & atrofische gastritis & & 28.3 & 19.0 \\
\hline \multirow[t]{3}{*}{$U$} & zoutzuurcellen & woldoende & 71.7 & 81.0 \\
\hline & & verminderd & 15.2 & 9.5 \\
\hline & & afwezig & 13.1 & 9.5 \\
\hline
\end{tabular}

${ }^{*} p<0.01 * * * p<0,05$, chi-kwadraattoets 
ad. $3 b$. Vergelijking van endoscopische en histologisch beelden van niet-carcinoompatiŏnten met een BII-resectiemaag, meer dan 10 jaar postoperatief, onderscheiden marir het al of net aanwezig zijn van klachten, onderzocht in de periode 1980 tot en met 1982

Wanneer groepen niet-carcinoompatienten met een BII-resectienaag, meer dan 10 jaar postoperatief, onderscheiden naar het al dan niet aanwezig zijn wan klachten, vergeleken worden ten aanzien van endoscopische en histologische beelden, komen voor deze vergelijking in aanmerking de groep BII-patiënten met klachten uit de periode 1980 tot en met 1982 en de groep BII-patiënten zonder klachten uit de periode 1980 tot en met 1982 . In deze periode werden volgens protocol endoscopische beelden beoordeeld, voor histologisch onderzoek tenminste 4 biopten ter hoogte van het stoma en 4 biopten ter hoogte van het corpus van de restmaag genomen. In de periode 1970 tot en met 1979 is dit niet het geval geweest.

De algemene gegevens van endoscopisch onderzoek worden woor de groepen BII-patiënten met en zonder klachten vermeld in tabel 12.4 .

Tabel 12.4. Algemene endoscopiegegevens van de 104 patiënten met een BII-maag met klachten en de 133 patiënten met een BII-maag zonder klachten

\begin{tabular}{|c|c|c|c|}
\hline endoscopische ge & atiënten & $\begin{array}{l}\text { met klachten } \\
\% \\
n=104\end{array}$ & $\begin{array}{l}\text { Zonder klachien } \\
\% \\
n=133\end{array}$ \\
\hline \multirow[t]{3}{*}{ stoma } & normaal & 92.3 & 89.5 \\
\hline & plooiconvergentie & 6.7 & 9.0 \\
\hline & stenose & 1.0 & 1.5 \\
\hline \multirow[t]{3}{*}{ stomagastritis } & geen & 1.0 & 0.0 \\
\hline & matig & 31.7 & 32.3 \\
\hline & duidelijk & 67.3 & 67.7 \\
\hline \multirow[t]{3}{*}{ corpusgastritis } & geen & 29.8 & $11.3^{4}$ \\
\hline & matig & 57.7 & $74.4^{*}$ \\
\hline & duidelijk & 12.5 & 14.3 \\
\hline \multirow[t]{3}{*}{ hoeveelheid gal } & geen & 19.2 & 24.8 \\
\hline & matig & 37.5 & 37.6 \\
\hline & veel & 43.3 & 37.6 \\
\hline
\end{tabular}

" $p<0.01$, chi-kwadraattoets

Een corpusgastritis blijkt significant vaker te ontbreken bij patiënten met klachten $(p<0.01)$, een matig ernstige gastritis wordt significant vaker gezien bij patiënten zonder klachten dan bij patiênten met klachten $(p<0.01)$. Gesteld kan worden dat er geen duidelijke relatie bestaat tussen het al dan niet anwezig zijn van klachten en de aanwezigheid van een stoma- en corpusgastritis.

Bij vergelijking van de bijzonderheden vastgesteld bij endoscopisch onderzoek (zie Tabel 12.5.) blijken ulceratieve/erosieve laesies sugnificant vaker woon te komen bij symptomatische patiënten dan bij symptoomloze patiënten met een BII-resectiemaag $(p<0.01)$. Dit gegeven is positief gekorreleerd aan het aanwezig zijn van klachten. Overigens zijn er weinig opvallende verschillen in het endoscopisch beeld tussen beide groepen patiënten.

Tabel 12.5. Bijzondere endoscopische bevindingen bij de 104 patiënten met een BIImag met klachten en de 133 patiënten met een BII-maag zonder klachten

\begin{tabular}{|c|c|c|}
\hline endoscopie gegeveris/aantal patiënten & $\begin{array}{l}\text { met klachten } \\
\% \\
n=104\end{array}$ & $\begin{array}{l}\text { zonder kiachten } \\
\% \\
n=133\end{array}$ \\
\hline $\begin{array}{l}\text { forse plooien stoma } \\
\text { jejunumslijmvlies op rand stoma } \\
\text { wittige plekken stoma/corpus } \\
\text { ulcus pepticum jejuni } \\
\text { ulcus stoma } \\
\text { ulcus praestoma } \\
\text { suspect ulcus pratestoma } \\
\text { erosie jejunum } \\
\text { xantelasmata } \\
\text { adenomateus weefsel } \\
\text { kwetsbaar slijmvlies stoma } \\
\text { poliepen } \\
\text { oesophagitis }\end{array}$ & $\begin{array}{r}14.4 \\
8.6 \\
9.6 \\
7.7 \\
1.9 \\
0.9 \\
0.9 \\
0.9 \\
7.7 \\
0.0 \\
0.0 \\
0.0 \\
1.9\end{array}$ & $\begin{array}{r}6.8 \\
6.0 \\
9.1 \\
1.5 \\
0.0 \\
0.7 \\
0.0 \\
0.0 \\
12.0 \\
1.5 \\
2.3 \\
3.0 \\
0.7\end{array}$ \\
\hline
\end{tabular}

${ }^{*} \mathrm{p}<0.01$, chi-kwadraattoets 
Bij vergeluking van de beelden op histologisch niveau (zie Tabel 12.6.) blijkt bij patiënten zonder klachten een focale ontsteking ter hoogte van het corpus significant vaker voor te komen $(p<0.02)$. Hetzelfde geldt woor het histologische fenomeen intestinale metaplasie van het corpus $(p<0.02)$. Een duidelijke relatie tussen het al of niet aanwezig zijn van klachten en afwijkingen op histologisch niveau kan niet worden gelegd.

Tabel 12.6. Gegewens van histologisch onderzoek van de 104 patiënten met een BII-maag met klachten (104 stoma- en 103 corpusbiopsieen) en de 133 patienten met een BII-maag zonder klachten (133 stoma-en 133 corpusbiopsieèn)

\begin{tabular}{|c|c|c|c|c|}
\hline & tologische gegeverns/antal & enten & $\begin{array}{l}\text { met klachten } \\
\% \\
n=104 / 103\end{array}$ & $\begin{array}{l}\text { zonder klachten } \\
\% \\
n=133\end{array}$ \\
\hline \multirow[t]{3}{*}{$\mathrm{S}$} & slijmvlieskarakter stoma & antrum & 44.2 & 47.4 \\
\hline & & corpus & 50.0 & 48.9 \\
\hline & & antrum/corpus & 5.8 & 3.7 \\
\hline \multirow[t]{3}{*}{$\mathrm{T}$} & ontsteking stoma & geen & 9.6 & 18.0 \\
\hline & & focal & 20.2 & 21.1 \\
\hline & & diffuus & 70.2 & 60.9 \\
\hline \multirow[t]{3}{*}{$\mathrm{O}$} & ontsteking stoma & geen & 9.6 & 18.0 \\
\hline & & licht & 40.4 & 42.2 \\
\hline & & matig & 38.5 & 33.8 \\
\hline \multirow[t]{3}{*}{$M$} & & ernstig & 11.5 & 6.0 \\
\hline & cysteuze werwijding & & 70.2 & 74.4 \\
\hline & intest inale metaplasie & & 16.3 & 21.8 \\
\hline \multirow{2}{*}{ A } & dysplasie & licht & 45,2 & 53.4 \\
\hline & & matig & 7.7 & 6.8 \\
\hline \multirow[t]{3}{*}{$\mathrm{C}$} & ontsteking corpus & geen & 28.2 & 21.8 \\
\hline & & focaal & 13.6 & $26.3 * *$ \\
\hline & & diffuus & 58.2 & 51.9 \\
\hline \multirow[t]{3}{*}{0} & ontsteking corpus & geen & 28.2 & 21.8 \\
\hline & & licht & 27.2 & 27.8 \\
\hline & & matig & 35.9 & 38.3 \\
\hline \multirow[t]{3}{*}{$\mathrm{R}$} & & ernstig & 8.7 & 12.1 \\
\hline & cysteuze werwijding & & 12.6 & 10.5 \\
\hline & intestinale metaplasie & & 10.7 & $23.3^{* *}$ \\
\hline \multirow[t]{2}{*}{$\mathrm{P}$} & dysplasie & licht & 8.7 & 6.0 \\
\hline & atrofische gastritis & & 29.1 & 36.8 \\
\hline \multirow[t]{3}{*}{$\mathrm{U}$} & zoutzuurcellen & voldoende & 68.0 & 57.9 \\
\hline & & verminderd & 18.4 & 29.3 \\
\hline & & afwezig & 13.6 & 12.8 \\
\hline
\end{tabular}

**t $p<0.02$, chi-kwadraattoets

ad. 4a. Vergelijking wan de frequentie van voorkomen van het stompcarcinoom en de prognose van het stompcarcinoom van patiënten met een BI-resectiemaag, meer dan 10 jaar postoperatief, onderscheiden naar het al of niet aanwezig zijn van klachten, onderzocht in de periode 1970 tot en met 1982

Bij de vergelijking van de frequentie van voorkomen van het stompcarcinoom en de prognose van het stompcarcinoom wordt tevens de groep patiënten met een BI-resectiemaag uit de periode 1970 tot en met 1979 betrokken. Bij vergelijking van de gegevens wordt rekening gehouden met het feit dat de onderzoekperiode van de groep patienten met klachten zich uitstrekt over een periode van 13 jaar, het onderzoek van de patiënten zonder klachten over een periode van 3 jaar. Bij patiènten met een BI-resectiemaag, meer dan. 10 jaar postoperatief, onderzocht in verband met klachten in de periode 1970 tot en met 1982, werd tweemaal een stompcarcinoom gezien. Bij de symptoomloze patiënten, in de periode 1980 tot en met 1982 onderzocht op het voorkomen van een stompcarcinoom, werd geen stompcarcinoom gediagnostiseerd. Gesteld mag worden dat in de periode 1970 tot en met 1982 de frequentie van het voorkomen van stompcarcinomen in de BI-resectiemaag gering is, deze frequentie bedraagt $1.9 \%$ bij de patiënten $(n=106)$ die in verband met klachten werden onderzocht, $1.3 \%$ bij de totale groep patiënten met een BI-resectiemaag $(n=149)$, onderzocht in deze periode. 
De prognose van beide symptomatische patienten met een stompcarcinoom bleek uitermate slecht te zijn, een maand na diagnosestelling zijn beide patiènten overleden.

ad. $4 b$. Vergelijking van de frequentie van vook komen van het stompcarcinoom en de prognose van het stompcarcinoom van patienten met een BII-resectiemaag, meer dan 10 jaar postoperatief, onderscheiden naar het al of niet aanwezig ziju van klachten, onderzocht in de periode 1970 tot en met 1982

Bij de vergelijking van de frequentie van woorkomen van het stompcarcinoom en de prognose van het stompcarcinoom wordt tevens betrokken de groep Bll-patiënten uit de periode 1970 tot en met 1979. Rekening wordt gehouden met het feit dat van de patiènten met klachten de onderzoekperiode zich uitstrekt over een periode wan 13 jaar, van de patiënten zonder klachten over een periode van 3 jaar.

Bij 292 patiënten met een BII-resectiemaag, meer dan 10 jaar postoperatief, onderzocht in verband met klachten in de periode 1970 tot en met 1982 werd 34 maal een stompcarcinoom vastgesteld: $11.6 \%$. In de periode 1970 tot en met 1979 werden 20 stompcarcinomen gediagnostiseerd bij 174 patiënten $(11.5 \%$ ), in de periode 1980 tot en met 1982 werden 14 stompcarcinomen vastgesteld bij 118 patienten $(11.8 \%)$.

Bij 138 symptoomloze patiënten werd in de periode 1980 tot en met 1982 vijfmaal (3.6\%) een stompcarcinoom gediagnostiseerd. Wanneer deze percentages stompcarcinomen vergeleken worden voor de periode 1980 tot en met 1982 , dan blijkt bij symptomatische patiënten het percentage $11.8 \%$, bij symptoomloze patiënten $3.6 \%$ te bedragen. Het verschil is significant $(p<0.02)$.

Ten aanzien van het vraagstuk van de prognose worden de gegevens van de 34 symptomatische patiënten met een stompcarcinoom vermeld in Tabel 12.7. Een duidelijke korrelatie blijkt aanwezig tussen de uitgebreidheid van het maligne proces en de overlevingsduur.

Bij de 5 symptoomloze patiënten met een stompcarcinoom bleek er in alle gevallen sprake te zijn van een early gastric carcinoma. Een patiënt is postoperatief overleden aan de gevolgen van een longembolie, een patiënt heeft in een depressieve bui suicide gepleegd. De overige 3 patiënten zijn in leven, in goede algemene conditie. De gemiddelde overlevingsduur van deze 3 patiënten bedraagt tot dusver (februari 1983) 13 maanden.

Er lijkt een duidelijk verschil in prognose te bestaan: bij patiënten met een symptomatisch stompcarcinoom is door de uitgebreidheid van het proces de prognose meestal somber, bij patiënten met een stompcarcinoom in de symptoomloze fase is er vaak sprake van een carcinoom in een vroege fase, waarvan de prognose na in opzet curatief chirurgisch ingrijpen, goed is.

Tabel 12.7. Verschillende vormen van behandeling met corresponderende overlevingsduur van 34 symptomatische patiënten met een stompearcinoom

\begin{tabular}{|c|c|c|c|c|c|c|}
\hline $\begin{array}{l}\text { behandelings- } \\
\text { wormen }\end{array}$ & $\begin{array}{l}\text { totalal } \\
\text { aantal } \\
\text { patienten }\end{array}$ & $\begin{array}{l}\text { gemiddelde } \\
\text { overleving } \\
\text { in maanden }\end{array}$ & $\begin{array}{l}\text { overlede } \\
\text { aantal }\end{array}$ & $\begin{array}{l}\text { atiënten } \\
\text { gemiddelde } \\
\text { owerlevings- } \\
\text { tijd (mnd) }\end{array}$ & $\begin{array}{l}\text { nog in } \\
\text { aantal }\end{array}$ & $\begin{array}{l}\text { zijnde pat. } \\
\text { gemiddelde } \\
\text { owerlevings } \\
\text { tijd (mnd) }\end{array}$ \\
\hline $\begin{array}{l}\text { subtotale } \\
\text { maagresectie } \\
\text { beperkte }\end{array}$ & 5 & 47.6 & 2 & 750 & 3 & 29.3 \\
\hline $\begin{array}{l}\text { maagresectie } \\
\text { inoperabell }\end{array}$ & $\begin{array}{r}4 \\
11\end{array}$ & $\begin{array}{r}23.2 \\
5.5\end{array}$ & $\begin{array}{r}4 \\
11\end{array}$ & $\begin{array}{r}23,2 \\
5,5\end{array}$ & - & - \\
\hline $\begin{array}{l}\text { geen operatie } \\
\text { i. } v \text { m. proces } \\
\text { geen operatie }\end{array}$ & 6 & 1.2 & 6 & 1.2 & - & - \\
\hline $\begin{array}{l}\text { i.v.m. leeftijd } \\
\text { postoperatief } \\
\text { overleden }\end{array}$ & 6 & 18.8 & 4 & 17.5 & 2 & 21.5 \\
\hline
\end{tabular}

* uitgebreidheid proces en/of metastasen 
ad. Sa. Vergeliking van gegevens wan patiënten met een BI- en BII-resectiemaag, meer dan 10 jaatr postoperatief, onderzocht in verband met klachten in de periode 1970 tot en met 1979 (groep A)

Wanneer de gegevens van onderzoek van de groepen BI- en BII-maagresectiepatiënten, onderzocht in de periode 1970 tot en met 1979, worden vergeleken, blijkt een stompcarcinoom procentueel vaker voor te komen bij patiënten met een BII-resectiemaag (BI-maag: $3.5 \%$; BII-maag: $11.5 \%$ ). Dit verschil blijkt echter niet significant te zijn bij deze geringe aantallen stompcarcinomen. De groepen zijn goed vergelijkbaar wat betreft de gemiddelde leeftijd en gemiddeld interval.

Histologische gegevens van de groepen niet-carcinoompatiënten met een BI- en BII-resectiemaag worden vergeleken, teneinde na te gaan of er verschillen aanwezig zijn, mogelijk relevant ten aanzicn van het vraagstuk van de frequentie van woorkomen van het stompcarcinoom in de BI- en BII-maag. Het betreft 55 patienten met een BI-maag (gemiddelde leeftijd 57.3 jaar; gemiddeld interval 19.3 jaar) en 154 patiënten met een BII-maag (gemiddelde leeftijd 57.4 jaar; gemiddeld interval 22.8 jaar).

Tabet 12.8 Vergelijking van de onderzoekgegevens van de 55 niet-carcinoompatiënten met een BI-maag ( 54 stoma- en 50 corpusbiopsieën) en de 154 niet-carcinoompatiënten met een BI-maag (149 stoma- en 145 corpusbiopsieën).

\begin{tabular}{lll}
\hline Onderzoekgegevens/aantal patiénten & $\begin{array}{c}B I-\operatorname{mag}(\%) \\
n=54 / 50\end{array}$ & $\begin{array}{c}B I \text {-maag }(\%) \\
n=149 / 145\end{array}$ \\
\hline karakter stomaslijmvlies: antrum & 20.4 & $48.3^{*}$ \\
stomagastritis: licht $\quad$ corpus & 77.8 & $51.7^{*}$ \\
$\quad$ matig & 37.0 & 46.3 \\
cysteuze verwijding klierbuizen stomat & 55.6 & $43.6^{* * * *}$ \\
intestinale metaplasie stoma & 58.2 & 73.1 \\
dysplasie stoma: licht & 7.3 & 14.1 \\
$\quad$ matig & 16.7 & 26.2 \\
corpusgastritis: licht & 1.8 & 2.0 \\
matig & 40.0 & 46.2 \\
intastinale metaplasie corpus & 36.0 & 32.4 \\
dysplasie corpus: licht & 6.0 & 9.0 \\
atrofische gastritis corpus & 0.0 & 2.8 \\
\hline
\end{tabular}

* $p<0.01 \quad * * * p<0.05$, chi-kwadratattoets

Bij vergelijking van de gegevens (zie Tabel 12.8) blijkt stomaslijmvlies van het antrumkarakter bij de BII-maaggroep significant vaker voor te komen dan bij de BI-maaggroep $(p<0.01)$; intestinalle metaplasie ter hoogte van het stoma blijkt bij de BII-maaggroep twee maal zo frequent alanwezig als bij de BI-maaggroep, het verschil is niet significant. Een cysteuze verwijding van klierbuizen komt ter hoogte van het stoma van patiënten met een BI-maag minder frequent voor dan bij patiēnten met een Bll-maag. Dit verschil is niet significant.

Met de ter beschikking staande gegevens kan geen antwoord gegeven worden op de vraag, waarom het stompcarcinoom drie maal zo frequent voorkomt bij patiënten met een BII-maag als bij patięnten met een BI-maag. Men zou zich kunnen afvragen of het twee maal zo frequent voorkomen van antrumslijmvlies ter hoogte van het stoma van patiënten met een BII-maag enige betekenis heeft. Verandert het stomaslijmvlies van de BII-maag frequenter dan dat van de BImaag onder invloed van galreflux van een corpus- in een antrumtype? Geeft dit een grotere kans op een stompcarcinoom bij gecontinueerde prikkeling door galreflux? Ook met behulp van gegevens uit de literatuur is op deze vraag geen antwoord te geven.

ad. $5 b$. Vergelijking van gegevens van patiënten met een BI-en BII-resectiemaag, meer dan 10 jaar postoperatief, onderzocht in verband met klachten in de periode 1980 tot en met 1982 (groep B) 


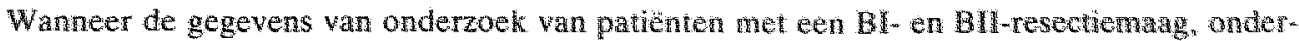
zocht in verband met klachten in de periode 1980 tot en net 1982 vergeleken worden, bhk een stompcarcinoom significant vaker woor te komen bij patienten met een BII-maag $(p<0,02)$. De groepen zjin goed vergeljkbaar ten aanzien van gemidelde leftiyd en gemideld interval. Gegevens wan de groepen net-carcinoompatienten met een BI-en Bl-maag worden vergeleken, teneinde a te gaan of er verschillen aanwezig zijn, mogelijk relevant tea araien wam hot vraag. stuk van de frequentie van voorkomen van het stompcarcinoom in de BL-en BII-maag. Het betreft 49 patienten met een BI-maag (geniddelde leeftid 61.5 jaar, gemóndeld interval $20.7 \mathrm{jag}$ ) en 104 patiënten met een BI-mag (gemiddelde leeftijd 62.0 jatr, gemiddeld interval 26.1 jarar).

Tabel 12.9. Vergelijking van de onderzoekgegevens van de 49 niet-curcinoompatiènten met een Bl-maag

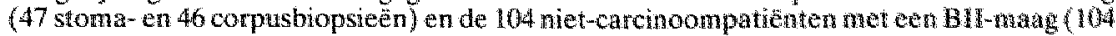
stoma- en 103 corpusbiopsieèn)

\begin{tabular}{|c|c|c|}
\hline onderzoekgegevensfaantal patienten & $\begin{array}{l}B I-\operatorname{mag}(\%) \\
n=47 / 46\end{array}$ & $\begin{array}{l}\text { BII-rmatag (o) } \\
n=104 / 09\end{array}$ \\
\hline slijmvlieskarakter stoma: antrum & 31.9 & 44.2 \\
\hline corpus & 63.8 & $50.0 \%$ \\
\hline stomagastritis: licht & 38.4 & 40.4 \\
\hline matig & 40.4 & 38.5 \\
\hline cysteuze werwijding klierbuizen stoma & 48.9 & $70.2^{2 * *}$ \\
\hline intestinale metaplasie stoma & 23.4 & 16.3 \\
\hline dysplasie stomat licht & 36.2 & 45.2 \\
\hline matig & 2.1 & 7.7 \\
\hline corpusgastritis: licht & 45.7 & $27.2 * * *$ \\
\hline matig & 23.9 & 35.9 \\
\hline intestinale metaplasie corpus & 8.7 & 10.7 \\
\hline dysplasie corpus: licht & 0.0 & 8.7 \\
\hline atrofische gastritis corpus & 28.3 & 29.1 \\
\hline hoeveetheid gal maagrest: matig & 38.8 & 37.5 \\
\hline duidelijk & 12.2 & $43.3^{\text {* }}$ \\
\hline
\end{tabular}

* $p<0.01{ }^{* *} p<0.02 * * * 0<0.05$, chi-kwadraattoets

Bij vergelijking van de gegevens (zie Tabel 12.9.) komen er enkele duidelike verschillen naar voren. Slijmvlies van het corpuskarakter wordt ter hoogte van het stoma significant vaker gezien bij de BI-maag $(p<0.05)$, cysteuze verwijding van klierbuizen ter hoogte van het stoma significant vaker bij de BII-maag $(p<0.02)$. Een lichte corpusontsteking wordt significant vaker gezten bij de BI-maag $(\mathrm{p}<0.05$ ), een lichte dysplasie van corpusepitheel significant vaker bij de Bllmaag $(p<0.05)$. Een duidelijke hoeveelheid gal blijkt significant vaker gezien te worden in de Bll-maag $(p<0.01)$.

Gegevens uit de literatuur (dierexperimenteel onderzoek wan Dahm en Werner 1973 , Langhans e.a. 1980) steunen de veronderstelling, dat or en relatie bestaat tussen de ernst van de gallige reflux in de resectiemaag en het hieraan positief gekorreleerde risico op het ontstaan van een stompcarcinoom.

Hypotheses dat ten gevolge van een minder ernstige galleflux in de Bl-resectiemaag op vee: langere termijn een stompcarcinoom zich zou ontwikkelen, dat onder invloed van galreflux het stomaslijmvlies van een corpustype zou veranderen in een antrumtype, hetgeen dan een groter risico op een stompcarcinoom zou geven via gecontinueerde prikkeling via galreflux, zijn speculatief. Over de betekenis van een matige dysplasie als precancereuze aandoening van de resectiemaag zijn de meningen verdeeld.

ad. $5 c$. Vergelijking van gegevens van symptoomloze patiënten met ecn BI- en BII-resectiemaag, meer dan 10 jaar postoperatief, onderzocht op het voorkonen van een stompcarcinoom in de periode 1980 tot en met 1982 (groep C)

Wanneer de gegevens van symptoomloze patiënten met een BI- en BII-resectiemaag, in de periode 1980 tot en met 1982 volgens dezelfde procedure onderzocht op het voorkomen wan een stompcarcinoom, worden vergeleken, blijkt een stompcarcinoom wel aanwezig in de BII-maag. ( 5 van de 138 patiënten) en niet in de BI-maag ( 0 van de 43 patiënten). Het verschil is niet significant. De groepen zijn goed vergelijkbaar ten aanzien van gemiddelde leeftijd en gemiddeld in- 
terval. Gegevens van de groepen niel-carcinoompatiênten met een BI-maag en een BlI-maag worden vergeleken, teneinde na te gaan of verschillen aanwezig zijn, mogelijk relevant wat betreft het vraagstuk van de frequentie van voorkomen van het stompcarcinoom in de BI- en BIImaag. Het betreft 43 patienten met een Bl-maag (gemiddelde leeftijd 61 . 4 jaar; gemiddeld interval 23.0 jaar) en 133 patienten met een Bll-maag (gemiddelde leeftijd 61.9 jaar; gemiddeld interval 25.4 jaar).

Tabel 12.10. Vergelijking van de onderzoekgegevens van de 42 niet-carcinoom patiènten met een BImaag ( 42 stoma- en 42 corpusbiopsieern) en de 133 niet-carcinoom patiènten met een BIImaag (133 stoma- en 133 corpusbiopsieër)

\begin{tabular}{|c|c|c|}
\hline onderzoekgegewens/antal patienten & $\begin{array}{l}B I-m a g(\%) \\
n=42\end{array}$ & $\begin{array}{l}B I \text {-maag }(\%) \\
n=1,33\end{array}$ \\
\hline slijmvlieskarakter stoma: antrun & 16.7 & $47.4 *$ \\
\hline corpus & 78.6 & $48.9^{*}$ \\
\hline stomagastritis: licht & 31.0 & 42.2 \\
\hline matig & 47.6 & 33.8 \\
\hline cysteuze we rwijding klicrbuizen stoma & 26.2 & $74.4^{\text {* }}$ \\
\hline intestinale metaplasie stoma & 21.4 & 21.8 \\
\hline dysplasiee stomat: licht & 33.3 & $53.4 * *$ \\
\hline matig. & 9.5 & 6.8 \\
\hline corpusgastritis: licht & 11.9 & $27.8^{\text {sisk }}$ \\
\hline matig & 45.2 & 38.3 \\
\hline intestinale metaplasie corpus & 14.3 & 23.3 \\
\hline dysplasie corpus: licht & 0.0 & 6.0 \\
\hline atrofische gastritis corpus & 19.0 & $36.8^{*}$ \\
\hline hoeveelheid gal restmaag: matig & 27.9 & 37.6 \\
\hline duidelijk & 18.6 & $37.6^{* * * *}$ \\
\hline
\end{tabular}

* p $<00,01$ "*** $p<0.05$, chi-kwadraattoets

Bij vergelijking van de gegevens (zie Tabel 12.10.) komen er enkele significante verschillen naar voren. Slijmwlies van het antrumkarakter komt significant vaker voor ter hoogte van het stoma van de BII-maag $(p<0.01)$, slijmvlies van het corpuskarakter ter hoogte van het stoma van de BImaag ( $p<0.01)$. Cysteuze verwijding van klierbuizen wordt significant vaker gezien ter hoogte van het stoma van de BII-maag $(\mathrm{p}<0.01)$; hetzelfde geldt voor het fenomeen lichte dysplasie $(p<0.05)$. Een lichte corpusontsteking en atrofische gastritis wordt eveneens significant vaker vastgesteld bij patiënten met een BIII-maag $(p<0.05)$. Bij endoscopie wordt een duidelijke hoeveelheid gal significant vaker vastgesteld bij patiënten met een BII-maag $(p<0.05)$.

Gegevens uil de literatuur (dierexperimenteel onderzoek Dahm en Werner 1973, Langhans e.a. 1980) steunen de veronderstelling, datt er een relatie bestaat tussen de ernst van de gallige reflux in de resectiemaag en een verhoogd risico op een stompcarcinoom. Hypotheses, dat onder invloed van de galreflux het stomaslijmwlies van een corpus- in een antrumtype zou veranderen, het antrumslijmvlies bij gecontinueerde prikkeling door galreflux gepredisponeerd zou zijn voor de ontwikkeling van een stompcarcinoom, zijn speculatief. Een matige dysplasie ter hoogte van het stoma, door sommigen gezien als een premaligne aandoening, komt in deze serie even frequent voor bij patiënten met een BI-resectiemaag als bij patiënten met een Bll-resectiemaag (de 5 patiènten met een stompcarcinoom meegerekend). Dit gegeven zou kunnen pleiten tegen het premaligne zijn van het fenomeen matige dysplasie.

ad. 6. De betekenis van het symptoom bloeding als late postoperatieve complicatie bij patienten met een BIT-resectiemaag, onderzacht in de periode 1970 tor en met 1982

In de periode 1970 tot en met 1982 werden 51 patiënten met een BII-resectiemaag endoscopisch onderzocht in verband met verschijnselen van een bloeding uit het bovenste gedeelte van het maagdarmkanaal. De primaire operatie werd bij 38 patiënten meer dan 10 jaar voor het onderzoek verricht. Endoscopisch en histologisch werd een stompcarcinoom vastgesteld bij 9 van de 38 patiënten $(23.7 \%)$.

Zes van de 9 carcinoompatiënten $(66.7 \%)$ hadden geen klachten van verminderde eetlust, vermagering, zuurbranden, opboeren, misselijkheid, overgeven en pijn. Vijftien wan de 42 niet-carcinoom patiënten $(35.7 \%)$ waren eveneens klachtenvrij. 
Wanneer de anamnese bekeken wordt op factoren mogelik ten grondslag liggend gan de bloeding zoals antïstollingstherapie, gebruik van analgetica, alcoholabusus en dergelijke, wordt bij éen van de 9 carcinoompatiènten ( $11.1 \%$ ) en bij 18 van de 42 niet-carcinoom patiënten $(42.8 \%)$ in de anamnese een potentiële oorzak woor de bloeding gevonden.

Bij operatie bleek het carcinoom bij 2 patiënten inoperabel te zijn, vijfmal werd een resectie verricht. Bij 2 patiènten vond geen operatie plaats gezien de gevorderde leeftijd en matige algemene conditie in het ene gevall, de leeftijd en uitgebreidheid van het proces in het andere geval. Twee patiënten zijn overleden aan complicaties van de operatie, 4 patiẻnten zijn overleden na gemiddeld 13.5 maanden $(4,8,18$ en 24 maanden), 3 patiènten zijn in februari 1983 nog in leven na gemiddeld 24.3 maanden.

De prognose van deze groep patiënten is derhalve slecht, maar lijkt iets minder ongunstig dan de prognose van patiënten, bij wie een stompcarcinoom ge diagnostiseerd wordt naar aanleiding van klachten zoals verminderde eetlust en duidelijke vermagering.

Wanneer er zich derhalve bij patiënten met een BII-resectiemaag, meer dan 20 jaar postoperatief, een bloeding voordoet, dient, zeker wanneer er vanuit de anamnese geen potentiële oorzaak voor de bloeding naar voren komt, gedacht te worden aan de mogelijkheid van een carcinoom in de restmaag.

\section{ad. 7. De betekenis van het histologische fenomeen matige dysplasie als eventueel premaligne kenmerk wan het stompcarcinoom}

In verband met de vraagstelling of het fenomeen matige dysplasie ter hoogte van het stoma enige betekenis heeft als precancereuze afwijking in de resectiemaag, werden de verschillende series patiënten met BI- en BII-resectiemagen bekeken op het voorkomen wan een matige dysplasie ter hoogte van het stoma.

De frequentie van voorkomen kan als wolgt worden weergegeven (patiënten met en zonder carcinoom van de restmaag zijn apart vermeld):

- groep BII-patiënten met klachten, periodie 1970 tot en met 1979:

o 149 niet-carcinoompatiënten: driemaal matige dysplasie $=2.0 \%$

- 20 carcinoompatiënten: driemaal matige dysplasie $=15,0 \%$

Opmerking: het stoma van 11 carcinoompatiënten is niet te beoordelen (zevenmaal door* groeid door carcinoom, viermaal geen gegevens);

- groep BII-patiënten met klachten, periode 1980 tot en met 1982:

o 104 niet-carcinoompatiënten: achtmaal matige dysplasie $=7.7 \%$

o 14 carcinoompatiënten: tweemaal matige dysplasie $=14.3 \%$

Opmerking: het stoma van 4 carcinoompatiënten is niet te beoordelen (diffuus doorgroeid door carcinoom);

- groep BII-patienten zonder klachten, periode 1980 tot en met 1982 :

o 133 niet-carcinoompatiënten: negenmaal matige dysplasie $=6.8 \%$

- 5 carcinoompatiënten: viermaal matige dysplaise $=80.0 \%$;

groep BII-patiënten met bloeding, periode 1970 tot en met 1982:

o 34 niet-carcinoompatiënten: nulmaal matige dysplasie $=0.0 \%$

o 9 carcinoompatienten: tweemal matige dysplasie $=22.2 \%$

Opmerking: het stoma van 3 carcinoompatiënten was niet te beoordelen (geen gegevens);

- groep BI-patiënten met klachten, periode 1970 tot en met 1979:

o 54 niet-carcinoompatiënten: eenmaal matige dysplasie $=1.8 \%$

o 2 carcinoompatiënten: eenmaal matige dysplasie $=50.0 \%$

Opmerking: het stoma van 1 carcinoompatient was niet te beoordelen (diffuus doorgroeid door carcinoom);

groep BI-patienten met klachten, periode 1980 tot en met 1982 :

- 47 niet-carcinoompatiënten: eenmaal matige dysplasie $=2.1 \%$;

groep BI-patiënten zonder klachten, periode 1980 tot en met 1982 :

$\circ \quad 42$ niet-carcinoompatiënten: viermaal matige dysplasie $=9.5 \%$.

Opgemerkt dient te worden dat in de periode 1970 tot en met 1979 minder biopten ter hoogte van het stoma genomen werden, hetgeen het geringe aantal vastgestelde matige dysplasieën ter hoogte van het stoma in deze periode in de hand gewerkt kan hebben.

Berekend over de 420 niet-carcinoompatiënten met een BII-resectiemaag wordt een matige dysplasie 20 maal ( $4.8 \%$ ) gezien; bij de 48 carcinoompatiënten met een BII-resectiemaag wordt de 
matige dysplasic 11 maal (22.9\%) wastgesteld, warbij aangetekend dat 18 maal het stoma hierop niet beoordeeld kon worden (11 mal diffuus doorwoekerd door carcinoom, zevenmaal geen hislologisch materiaal).

Bij de 104 niet-carcinoompatienten met een BI-resectiemaag werd ter hoogte van het stoma zesmal $(4.2 \%)$ een matige dysplasie vastgesteld; bij de 2 carcinoompatienten met een BI-resectiemagg bleek er eenmal ter hoogte van het stoma een matige dysplasie aanwezig, eenmaal was dit fenomeen niet te beoordelen ten gevolge van een doorwoekering wan het stoma met carcinoomweefsel.

Van de 20 niet-carcinoompatiënten met een BH-resectiemaag, waarbij ter hoogte van het stoma een matige dysplasie werd vastgesteld, werd bij 11 patiënten na ongeveer 1 jaar een endoscopisch controle-onderzoek verricht, waarbij zesmaal $(54.4 \%$ ) opnieuw een matige dysplasie naar voren gekomen is, vijfmaal geen afwijkingen in deze zin werden vastgesteld. De owerige patienten hebben tot dusver dit controle-onderzoek geweigerd. Hierbij bevinden zich 3 patiênten bij wie het eerste onderzoek 7,11 en 12 jaar geleden heeft plaatsgevonden. Deze patiënten zijn klachtenvrij, bevinden zich in een goede algemene conditie.

Bij de 6 patiënten met een BI-resectiemaag, bij wie een matige dysplasie ter hoogte van het stoma werd vastgesteld, werd bij 4 patiënten na ongeveer 1 jaar een endoscopisch controle-onderzoek verricht, waarbij tweemaal $(50.0 \%)$ opnieuw een matige dysplasie naar voren gekomen is, tweemaal geen afwijkingen in deze zin werden vastgesteld. De overige 2 patienten hebben tot dusver dit controle-onderzoek geweigerd.

Hoewel op basis van dit materiaal geen definitieve uitspraken ten alanzien van het histologisch fenomeen matige dysplasie gedaan kunnen worden, komen uit dit onderzoek de volgende gegevens naar voren:

- het fenomeen matige dysplasie komt in vrijwel gelijke mate voor ter hoogte van het stoma zowell in de BI- als de BII-resectiemaag;

- het fenomeen matige dysplasie wordt vaker gezien ter hoogte van het stoma van patiënten met een carcinoom van de restmaag, dan bij patiënten zonder carcinoom;

- ter vaststelling van het fenomeen matige dysplasie ter hoogte van het stoma dienen multipele biopten te worden genomen;

- bij controle-onderzoek van patiënten met een matige dysplasie ter hoogte van het stoma, wordt ondanks het nemen van multipele biopten, het fenomeen slechts bij ongeveer de helft wan de patiënten opnieuw aangetroffen;

- het fenomeen matige dysplasie ter hoogte van het stoma kan niet zonder meer beschouwd worden als een precancereuze afwijking.

ad. 8. De betekenis van endoscopisch en histologisch onderzoek van symptoomloze patiënten met een BI- en BII-resecticmag, meer dan 10 jaar postoperatief

Om exn curatieve behandeling van het carcinoom van de restmaag mogelijk te maken, dient dit carcinoom in een vroege fase te worden gediagnostiseerd. Bij onderzoek van klachtenvrije patiënten blijkt dit mogelijk te zijn, wanneer een ervaren endoscopist nauwkeurig de maag, met na" mo op geringe slijmvliesafwijkingen inspecteert en multipelle biopten voor histologisch onderzoek neemt.

Teneinde de vraag te kunnen beantwoorden of screening van patiënten met een resectiemaag haalbaar is, dienen de voorwaarden waaraan vroegdiagnostiek moet voldoen te worden nagegaan (van Es 1980):

- secundaire preventie moet de prognose verbeteren of de levenskans vergroten of de te verwachten nadelen van de ziekte verkleinen;

- het vereiste onderzoek moet voor de patiënt nauwelijks belastend en gemakkelijk aanvaardbatar zijn;

- het onderzoek moet geen risico"s voor de patiënt met zich meebrengen;

- risico"s en nadelen van een eventueel in te stellen behandeling moeten in verhouding staan tot de winst die deze behandeling kan opleveren;

- vroege symptomen moeten met een grote mate van zekerheid binnen afzienbare termijn leiden tot het krijgen van de ziekte:"

- als men wil screenen zal de ziekte of een zodanige frequentie moeten hebben dat de opbrengst in omvang redelijk genoemd kan worden of van zodanige ernst zijn, dat het ontdekken van de ziekte zeer belangrijke consequenties heeft; 
voor het onderzoek moet een methode beschikbaar zijn die zowel gevoelig als specifiek is;

- de eis moet gesteld worden dat de kosten (materiaal en mankracht) in verhouding staan tot andere kosten van de gezondheidszorg en in evenwicht zijn met het totale budget; ook kan men de eis stellen, dat kosten en baten tegen elkaar opwegen.

Deze voorwaarden achtereenvolgend aan een nadere beschouwing onderwerpend, kunnen de volgende opmerkingen gemaakt worden:

- Uit ons onderzoek komt naar voren dat de levenskansen van patiënten, curatief geopereerd in verband met een in een vroege fase vastgesteld carcinoom in de restmaag, un vergelijking met de levenskansen van patienten waarbij de diagnose gesteld is in de symptomatische fase aan. zienlijk vergroot lijken te zijn. Tegen de achtergrond wan het feit, dat de progressie van het maagcarcinoom in de praemaligne fase waarschijnlijk in dekaden, in de vroege fase in jaren en in eindstadia in maanden gemeten dient te worden, moet opgemerkt worden, dat ook zonder operatie patiënten met een carcinoom in de vroege fase naar alle waarschijnlijkheid nog jaren klachtenvrij zullen kunnen leven. De vijfjaars-overlevingsduur is na operatie van het carcinoom in de vroege fase (carcinoom beperkt tot de mucosa/submucosa) significant beter dan na operatie in een latere fase;

- Voor een aantal patiënten blijkt endoscopisch onderzoek nogal belastend en niet gemakkelijk aanvaardbaar in die zin, dat zij er op grond van verhalen van kennissen, buurtbewoners en anderen nogal tegen opzien. Vaak zijn deze patiënten tijdens onderzoek nogal onrustig en kokhalzen regelmatig, waardoor het onderzoek voor hen, vergeleken met de patiënten die het onderzoek rustig ondergaan, inderdaad nogal onaangenaam kan zijn.

Voorlichting aan de patiënt over het onderzoek en gebruik van lichte sedativa kunnen de onaangename kanten wan het onderzoek verminderen. In het kader van onderzoek van symptoomloze patiënten op een carcinoom van de resectiemaag, meer dan 10 jaar postoperatief, werden de huisartsen via een schrijven op de hoogte gesteld van aard en bedoelingen van het onderzoek. Het werd aan hen overgelaten patiënten hiervoor te selecteren en deze patiënten op de hoogte te brengen van de achtergrond van het onderzoek. Het aantal patiënten, dat na dit gesprek met de huisarts het onderzoek geweigerd heeft, is niet bekend. De patiënten die het onderzoek hebben ondergaan, hebben in het algemeen dit niet als erg onaangenaam ervaren. Tweemaal zijn er negatieve reacties ontvangen: eenmaal over het niet ingelicht zijn ten aanzien van de procedure van het nemen van biopten (maagklachten na onderzoek, het zich geplaatst zien in de patiëntenrol), eenmaal ten aanzien van de financiële aspecten van het onderzoek. In het algemeen kan gesteld worden dat het endoscopisch onderzoek van de maag niet gekwalificeerd kan worden als erg belastend, als niet gemakkelijk aanvaardbaar voor de patiënt.

- De risico's van de gastroscopie zijn over het algemeen gering. Het enige risico bij de vastgestelde procedure bleek de kans op een flinke nabloeding te zijn. Bij de 630 geëndoscopieerde patiënten heeft dit probleem zich vijfmaal $(0.79 \%)$ voorgedaan, tweemaal $(0.32 \%)$ bleek een ziekenhuisopname noodzakelijk. Overigens kan gesteld worden, dat bij klachtenvrije patięnten het risico op somatisering aanwezig is, wanneer zij geconfronteerd worden met de modedeling. dat er in de geopereerde maag afwijkingen aanwezig kunnen zijn, danwel in de nabije toekomst zich kunnen ontwikkelen. Wil men dit risico wolledig ontlopen, dan lijkt struisvogelpolitiek het enige alternatief.

- Risico's en nadelen wan de in te stellen chirurgische therapie lijken in werhouding tot de te behalen winst, wanneer bij de selectie van patiënten rekening gehouden wordt met de risico's van de eventuele operatieve procedure en patiënten met een duidelijk verhoogd risico worden uit. gesloten.

- Wanneer histologisch kenmerkende bevindingen, wijzend op de aanwezigheid van een carci-

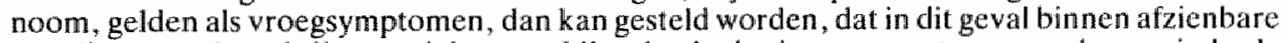
termijn er sprake zal zijn van ziekteverschijnselen in de zin van symptomen zoals verminderde eetlust, vermagering, opboeren, misselijkheid, overgeven, pijn, etc.

- Wanneer de te screenen populatie patiënten met een resectiemaag duidelijk gesellecteerd kan worden op grond van aanwezige criteria uit de grote groep patiënten met een maagoperatie in het verleden, zal naar alle waarschijnlijkheid de frequentie van voorkomen van het stompcarcinoom in deze groep voldoende hoog zijn om de opbrengst van onderzoek redelijk te noemen. De ernst van de aandoening is in ieder geval zodanig, dat vaststelling ervan belangrijke conse. quenties heeft.

- De endoscopie is een gevoelig onderzoekmethodiek voor zover door een ervaren endoscopist voor een maligne proces verdachte laesies macroscopisch kunnen worden vastgesteld, waarbij 
via histologisch onderzoek van genomen biopten door een ervaren patholoog-anatoom de díagnose carcinoom kan worden bevestigd. Vaker kunnen echter carcinomen in een vroege fase niet endoscopisch-macroscopisch worden herkend en dienen multipele biopsieen te worden genomen. Histologisch onderzoek kan de diagnose vroegcarcinoom alleen opleveren, wanneer de biopsieèn op de "goede" plek worden genomen. Een combinatie van factoren (een ervaren endoscopist en patholoog-anatoom, het aantal genomen biopsieën) bepaalt derhalve de gevoeligheid van dit onderzoek. De specificiteit van het onderzoek (endoscopie + histologie) blijkt goed te zijn.

- Wanner zorgvuldige selectie met ter beschikking staande criteria wordt toegepast, lijkt aan de eis dat kosten in verhouding dienen te staan tot andere kosten wan de gezondheidszorg, in evenwicht dienen te zijn met het totale budget, voldaan te kunnen worden. Ten aanzien van de eis dat kosten en baten tegen elkaar dienen op te wegen, moet worden gesteld, dat de mate van het beantwoorden aan deze eis niet ingeschat kan worden, zolang niet duidelijk is in hoeverre negatieve aspecten aan de screening verbonden zijn in de zin van somatisering van tot dusver klachtenvrije patiënten enz.

Het geheel aan voorwaarden voor toelaatbare screening van klachtenvrije patiënten met een resectiemaag overziende, lijkt aan de eisen hiervan niet zonder meer te kunnen worden voldaan. De beperkte kennis van het natuurlijke beloop van het stompcarcinoom door gebrek aan langetermijn follow-up studies van niet-geopereerde patiènten en van als precancereus beschouwde aandoeningen, maakt het vrijwel onmogelijk het nut van screening te beoordelen.

\section{ad. 9. Selectie van patiënten met een resectiemaag in aanmerking komend voor onderzoek op het voorkomen van een stompcarcinoom}

Onderzoek van symptoomloze patiënten met een resectiemaag biedt de enige mogelijkheid om het carcinoom in een curatieve fase te diagnostiseren. Het lijkt zinvol na te gaan of er valide criteria zijn op grond waarvan patiënten voor dit onderzoek geselecteerd kunnen worden.

- De resultaten van ons onderzoek wijzen er op, dat een carcinoom van de resectiemaag significant vaker gezien wordt bij patiënten met een BII-resectiemaag, dan bij patiënten met een BIresectiemaag. De BII-resectiemaag lijkt derhalve een groter risico te bieden op het ontstaan van een stompcarcinoom.

Gezien de slechte prognose van het carcinoom in de geopereerde maag, gediagnostiseerd in de symptomatische fase, wordt in de literatuur geadviseerd patiënten met een resectiemaag vanaf 10 jaar postoperatief regelmatig endoscopisch en histologisch te onderzoeken. Aangezien het interval tussen de operatie en de diagnosestelling carcinoom van de geopereerde maag gemiddeld ongeveer 30 jaar bedraagt, lijkt het tijdstip om het onderzoek 10 jaar postoperatief te beginnen te vroeg gekozen. Te frequent zou in dat geval onderzoek verricht worden bij patiënten, die op dat moment nauwelijks een risico lopen. Enerzijds brengt dit hoge kosten met zich mee, anderzijds de mogelijkheid dat de patiënten na enkele malen een endoscopisch onderzoek te hebben ondergaan, dit zullen weigeren in een fase, dat de kans op een carcinoom duidelijk verhoogd is. Om zo goed mogelijk het tijdstip vast te stellen waarop onderzoek moet plaats vinden, werd het onderzoekmateriaal statistisch bewerkt.

Uitgegaan werd van 3 patièntengroepen:

0292 patiënten met een BII-maag, onderzocht in verband met klachten in de periode 1970 tot en met 1982, in deze groep werden 34 carcinomen vastgesteld (groep KL);

- 51 patiënten met een BII-maag, onderzocht in verband met het symptoom bloeding in de periode 1970 tot en met 1982, in deze groep worden 9 carcinomen vastgesteld (groep BL); o 138 patiënten met een BII-maag zonder klachten, onderzocht in de periode 1980 tot en met 1982 , in deze groep werden 5 carcinomen vastgesteld (groep GK).

In de groepen KL en BL werden de meeste carcinomen vastgesteld in een late fase, de prognose van deze patiënten bleek slecht te zijn. Het is uiteraard niet vast te stellen wanneer deze carcinomen in een vroege fase verkeerden en nog curatief behandeld konden worden. Uitgangspunt voor de berekening van het tijdstip van onderzoek op een vroegcarcinoom vormde daarom de groep GK, waarin alle carcinomen in een vroeg stadium werden gediagnostiseerd. Tabel 12.11. geeft het gemiddelde tumorvrije tijdsinterval met de standaarderror, gebaseerd op tumorvrije overlevingskurven voor de groepen KL, BL en GK. Daar het langste tumorvrije interval voor de GK-groep (43 jaar) korter was dan de langste intervallen bij de groepen $\mathrm{KL}$ en 
BL (50 resp. 49 jaar), zijn bij deze laatste twee groepen de gemiddelden berekend over het tijdvak $0-43$ jaar. Hierdoor zijn de groepen beter vergelijkbaar. Deze gemiddelden en standaard-errors zijn in Tabel 12.11, 12.12 en 12.13 met een * aangeduid.

Tabel 12.11. Gemiddelde tumorvrije tijdsinterval met standaard-error van de groepen KL, BL, en GK

\begin{tabular}{llll}
\hline & $K L$ & $B L$ & $G K$ \\
\hline germ. & $39.23^{*}$ & $38.87^{*}$ & 41.57 \\
s.e. & $.602^{*}$ & $1.083^{*}$ & .657 \\
\hline
\end{tabular}

Het werschil tussen de groepen KL en BL bleek niet significant te zijn ( $p=0.575$, logranktoets), het verschil tussen de groepen KL en $G K$ was wel significant $(p=0.011$, logrank toets) terwijl het verschil tussen de groepen BL en GK eveneens significant bleek te zijn $(p=0.019, \log$ ranktoets).

Tabel 12.12. toont het gemiddelde tumorvrije tijdsinterval met de standaard-error wanneer de groepen KL en BL samengenomen worden en vergeleken met de groep GK. Het verschil blijkt significant te zijn ( $\mathrm{p}=0.007$, logranktoets).

Tabel 12.12. Gemiddelde tumorvrije tijdsinterval en standaard-error van de groepen KL + BL. en GiK

\begin{tabular}{lcc}
\hline & $K L+B L$ & $G K$ \\
\hline gem. & $38.97^{*}$ & 41.57 \\
s.e. & $.541^{*}$ & .657 \\
\hline
\end{tabular}

Figuur 12.2 geeft de overlevingskromme weer van de groepen KL, BL en GK. Deze carcinoomvrije overlevingsduurkromme geeft voor elk tijdstip het percentage patiënten dat nog geen carcinoom heeft.

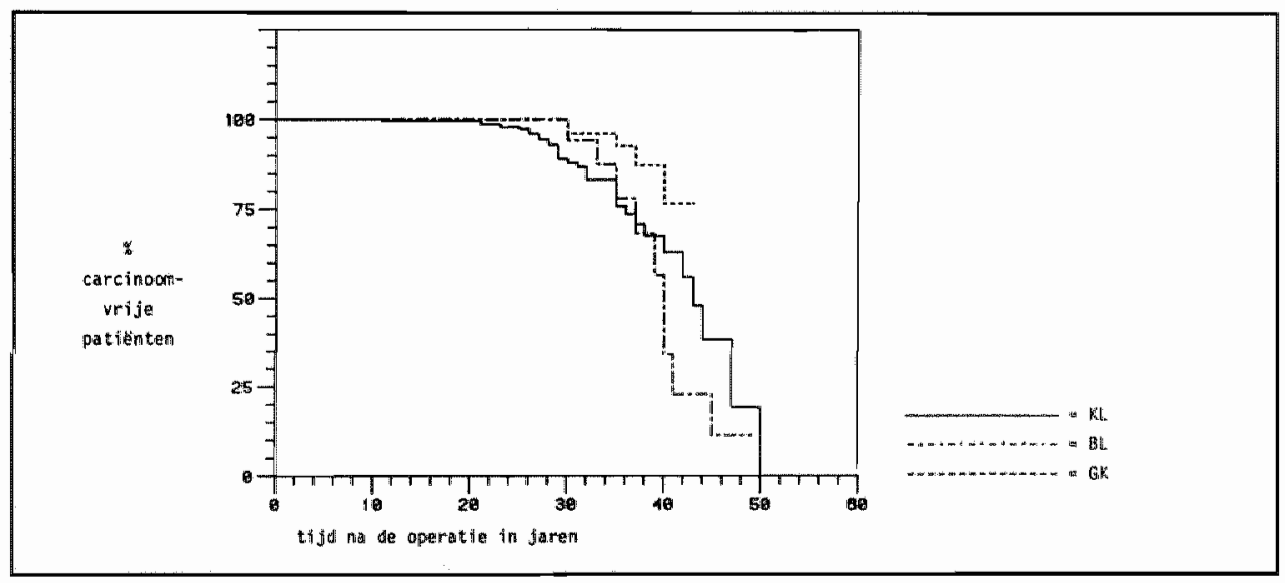

Figuur 12.2 Overlevingskromme van de groepen $\mathrm{KL}, \mathrm{GK}$ en $\mathrm{BL}$

Hieruit blijkt dat in de verschillende groepen 20 jaar postoperatief het aantal carcinoomvrije patiënten vrijwel $100 \%$ bedraagt. Dertig jaar na de primaire operatie bedraagt in de groep met een bloeding en in de klachtenvrije groep het carcinoompercentage ongeveer $100 \%$, terwijl dit in de groep met klachten ongeveer $88 \%$ is.

Wanneer voor het 99 e percentiel van de GK-groep (het tijdstip waarop $99 \%$ van de symptoomloze groep nog geen carcinoom heeft) een $95 \%$-betrouwbaarheidsinterwal wordt uitgerekend, blijkt dit het interval van 30 tot 40 te zijn.

Aangezien in de literatuur wordt aangegeven, dat het tijdsinterval wan primaire operatie tot diagnosestelling carcinoom langer is naarmate de patient op jeugdiger leeftijd geopereerd wordt, werd dit nagegaan voor de in ons onderzoek betrokken carcinoompatienten. De patiënten werden in 4 groepen opgesplitst naar de leeftijd bij primaire operatie: jonger dan 27 jaar, 27 tot en met 33 jaar, 34 tot en met 41 jaar en ouder dan 41 jaar. De gegevens worden vermeld in Tabel 12.13. 
Tabel 12.13. Leeftijd bij operatie en gemiddelde van tijdsinterval operatie - carcinoom met standaardarror

\begin{tabular}{lcccc}
\hline lectijdinjaren & $\$ 27$ & 27.34 & $34-42$ & $\geqslant 42$ \\
\hline gem. & $40.96^{*}$ & $39.42^{*}$ & 39.52 & $38.21^{*}$ \\
s.e. & $.708^{*}$ & $.772^{*}$ & .872 & $1.529^{*}$ \\
\hline
\end{tabular}

Hoewel er een lichte trend bestaat in de richting van een op een vroeger tijdstip optreden van een carcinoom bij de oudere patiënt, zijn de verschillen, met name tussen de uiterste groepern niet significant ( $p=0.169$, logranktoets). Hieruit kan worden geconcludeerd, dat de leeftijd bij operatie weinig unvloed heeft op het tijdstip van optreden van het carcinoom.

Uitdrukkelijk dient bij deze statistische gegevens te worden opgemerkt, dat gezien het geringe aantal carcinomen t. $O . v$. het aantal onderzochte patiënten, schattingen van grootheden en krommen bijzonder onnauwkeurig zijn. Met in achtneming hiervan, lijkt het redelijk bij symptoomloze patiënten met een BII-resectiemaag onderzoek te doen plaatsvinden vanaf 20 jaar postoperatief.

- Aangezien het fenomeen matige dysplasie niet beschouwd kan worden als een precancereuze aandoening en aangezien geen andere precancereuze aandoeningen tot dusver beschreven zijn, kan de waststelling van het tijdsinterval waarop onderzoek van de resectiemaag herhaald dient te worden, slechts arbitrair plaatsvinden. Bij patiënten, bij wie op grond van geringe slijmvliesafwijkingen bij endoscopie de verdenking op een stompcarcinoom in een vroege fase wordt uitgesproken en waarbij dit histologisch niet wordt bevestigd, zal controle endoscopisch onderzoek kunnen plaatsvinden na 3 tot 6 maanden. Wanneer er endoscopisch geen verdenking op een wroegcarcinoom bestaat en histologisch onderzoek van multipele biopten negatief blijkt te zijn, zal her-onderzoek kunnen plaatsvinden na een termi.jn van 1 tot 2 jaar.

Aangezien een curatief chirurgisch ingrijpen (totale of subtotale maagresectie) bij oudere patiënten met cardiovasculaire afwijkingen, een pulmonaal lijden en andere aandoeningen een duidelijk verhoogd operatierisico met zich meebrengt, dient bij de selectie van patiënten, die in aanmerking komen voor onderzoek, gesteld te worden, dat patiënten met een duidelijk verhoogd risico van onderzoek uitgesloten dienen te worden. In verband met de potentiële mogelijkheid van lasertherapie bij patiënten met een vroegcarcinoom van de maagstomp, dient nog opgemerkt te worden, dat het vroegcarcinoom multifocaal aanwezig kan zijn. Een gerichte lasertherapie zal derhalve niet goed mogelijk zijn. De vraag komt naar voren of bij eventueel toepassen van deze behandeling het noodzakelijk vaker te herhalen endoscopische controleonderzoek een haalbare kaart is bij de genoemde groep oudere patiënten. 


\section{Hoofdstuk 13}

\section{Conclusies}

Uit de bestudering van de literatuur en de gegevens van voorliggend onderzoek kunnen de volgende conclusies naar voren gebracht worden:

1. Hoewel er mogelijk verschillende pathogenetische mechanismen ten grondslag liggen aan de ontwikkeling van het carcinoom van de restmaag ten aanzien van de localisatie stoma en corpus, zijn er wat betreft gemiddelde leeftijd en gemiddeld interval, klachtenpatroon, endoscopische en histologische beelden geen werschillen van enige betekenis waarneembaar. Het heeft derhalve geen praktische consequenties het carcinoom van de restmaag naar localisatie te onderscheiden.

2. Door gebrek aan essentiële gegevens uit de periode van de operatie van de populatie patiēnten, die in het verleden in de regio Maastricht een maggresectie heeft ondergaan, is het niet mogelijk gebleken van deze patiënten een frequentie van voorkomen van het stompcarcinoom te berekenen.

Bij onderzoek van 617 patiënten met een BI- en BII-resectiemaag, meer dan 10 jaar postoperatief, werd een stompcarcinoom vaker gezien bij patiënten na een BII-resectie (468 patiènten, 48 stompcarcinomen $=10.3 \%)$ dan na een BI-resectie ( 149 patiënten, 2 stompcarcinomen $=1.3 \%)$. Het verschil is significant $(p<0.01)$.

3. Bij vergelijking van endoscopische en histologische beelden van niet-carcinoompatiënten met een BI-resectiemaag, meer dan 10 jaar postoperatief, onderscheiden naar het al of niet aanwezig zijn van klachten, worden er endoscopisch bij de patiënten met klachten significant meer ulceratieve/erosieve laesies vastgesteld $(p<0.05)$.

Histologisch bestaan er ten aanzien van de bestudeerde fenomenen geen significante verschillen, die in verband te brengen zijn met de klachten van de patiënt. Op grond van de gegevens van histologisch onderzoek komt de vraag naar voren, of klachten van deze patiènten mogen worden toegeschreven aan bij onderzoek vastgestelde afwijkingen van de maag, zoals een gastritis.

Bij vergelijking van endoscopische en histologische beelden van niet-carcinoompatiënten met een BII-resectiemaag, meer dan 10 jaar postoperatief, onderscheiden naar het al of niet aanwezig zijn van klachten, worden er endoscopisch bij de patiënten met klachten significant meer ulceratieve/erosieve laesies vasitgesteld $(p<0.02)$.

Histologisch bestaan er ten aanzien van de bestudeerde fenomenen geen significante verschillen, die in verband te brengen zijn met de klachten van de patiënt. Op grond van de gegevens van histologisch onderzoek kan de vraag gesteld worden of klachten van deze patiënten mogen worden toegeschreven aan bij onderzoek vastgestelde afwijkingen van de maag, zoals een gastritis.

4. De frequentie van woorkomen van het stompcarcinoom bij patienten met een BI-resectiemaag met en zonder klachten (106 patiënten met klachten, 2 stompcarcinomen $=1.9 \% ; 43$ patiënten zonder klachten, 0 stompcarcinomen $=0.0 \%$ ) verschilt niet significant. De prognose van thet stompcarcinoom bij symptomatische patienten is slecht.

De frequentie van voorkomen van het stompcarcinoom bij patiënten met een Bll-resectiemaag met en zonder klachten (118 patiënten met klachten, 14 stompcarcinomen $=11.8 \%$; 138 patiënten zonder klachten, 5 stompcarcinomen $=3.6 \%)$ verschilt significant $(\mathrm{p}<0.02)$. Het stompcarcinoom kan bij de symptoomloze patiënt als een vroegcarcinoom, vaak multifocaal van origine, ontdekt worden bij vroegtijdig onderzoek; de prognose van deze patiënten is goed. Het stompcarcinoom bij de symptomatische patiënt wordt vrijwel steeds in een latere fase vastgesteld; de prognose is in het algemeen slecht.

5. Bij vergelijking van endoscopische en histologische beelden van drie groepen niet-carcinoompatiënten onderscheiden naar de aanwezigheid van een BI- en BII-maag (groep A: met klachten 1970 tot en met 1979; groep B: met klachten 1980 tot en met 1982; groep C: zonder klachten 1980 tot en met 1982), meer dan 10 jaar postoperatief, komen de volgende gegevens naar voren:

- ter hoogte van het stoma van de BII-maag wordt frequenter slijmvlies van het antrumkarakter gezien dan ter hoogte wan het stoma van de $B I-m a a g ;$ in twee van de drie onderzochte groepen (groep A en $C$ ) is dit verschil significant $(p<0.01)$; 
- ter hoogte wan het stoma van de BII-maag wordt frequenter het fenomeen cysteuze verwijding van klierbuizen gezien dan ter hoogte van het stoma van de BI-maag; in twee van de drie onderzochte groepen (groep $B$ en $C$ ) is dit verschil significant $(p<0.02$ resp. $p<0.01$ ); het fenomeen cysteuze verwijding van klierbuizen ter hoogte van het stoma van de BII-maag kan gelden als een kenmerkend afwijkende bevinding van het stoma van de Bll-maag;

- ter hoogte wan de BII-maag wordt frequenter bij endoscopie een duidelijke hoeveeliheid gal gezien dan bij de BI-maag; in de twee hierop onderzochte groepen (groep B en C) is het verschil significant $(p<0.01$ resp. $p<0.05)$;

- ter hoogte van de BII-maag blijkt het stompcarcinoom frequenter voor te komen dan in de BI-maag; het verschill is in éen van de drie groepen (groep B) significant $(\mathrm{p}<0.02)$.

6. Wanneer zich bij patiënten met een BII-maag meer dan 20 jaar postoperatief een bloeding voordoet, dient, zeker wanneer er vamuit de anamnese geen potentiële oorzaak voor de bloeding naar voren komt, sterk rekening gehouden te worden met de mogelijkheid van een stompcarcinoom. De prognose van deze patiënten met een carcinoom van de restmaag is in het algemeen slecht.

7. Hoewel op basis wan bestudeerd materiaal geen definitieve uitspraken ten aanzien van het histologisch fenomeen matige dysplasie gedaan kunnen worden, komen uit dit onderzoek de volgende gegevens maar voren:

- ter vaststelling van het fenomeen matige dysplasie dienen multipele biopten te worden genomen ter hoogte van het stoma;

- het fenomeen matige dysplasie komt in vrijwel gelijke mate voor ter hoogte van het stoma zowel in de BI- als de BII-resectiemaag;

- het fenomeen matige dysplasie komt vaker voor ter hoogte van het stoma van patiënten met een carcinoom van de restmaag, dan bij patiënten zonder carcinoom;

- bij controle-onderzoek van patiënten met een matige dysplasie ter hoogte van het stoma, wordt ondanks het nemen van multipele biopten, slechts bij ongeveer de helft van deze patiënten opnieuw een matige dysplasie vastgesteld;

- het fenomeen matige dysplasie ter hoogte van het stoma kan niet zonder meer beschouwd worden als een precancereuze afwijking.

8. De voorwaarden voor een toelaatbare screening van symptoomloze patiënten met een resectiemaag aan een kritische beschouwing onderwerpend, lijkt aan de eisen hiervan niet zonder meer te kunnen worden voldaan.

9. Het blijkt mogelijk uit de populatie patiënten met een BI- en BHI-resectiemaag patiënten te selecteren, in aanmerking komend voor endoscopisch en histologisch onderzoek voor de vroegdiagnostiek van een stompcarcinoom in een nog curatieve fase. Deze patiënten kunnen als volgt worden gekarakteriseerd: patiënten met een BII-resectiemaag, vanaf 20 jaar postoperatief, zonder aandoeningen, waardoor een verhoogd operatierisico aanwezig is. 


\section{Chapter 12}

\section{Discussion}

In the following discussion, based on data acquired from examining literature and the results from my own study, the following items are under discussion:

1. the definition of the stump-carcinoma;

2. the frequency of occurrence of the stump-carcinoma after a BI-and a BII-resection;

3a. comparison of endoscopical and histological pictures of non-carcinoma patients with a Bl-re. section stomach, more than 10 years post-operative, differentiated according to the existence or non-existence of complaints, examined in the period from 1980 up to and including 1982;

3b. comparison of endoscopical and histological pictures of non-carcinoma patients with a BIIresection stomach, more than 10 years post-operative, differentiated according to the existence or non-existence of complaints, examined in the period from 1980 up to and including 1982 ;

4a. comparison of the frequency of occurrence of the stump-carcinoma and the prognosis of the stump-carcinoma of patients with a BI-resection stomach, more than 10 years post-operative, differentiated according to the existence or non-existence of complaints, examined in the period from 1970 up to and including 1982 ;

4b. comparison of the frequency of occurrence of the stump-carcinoma and the prognosis of the stump-carcinoma of patients with a BlI-resection stomach, more than 10 years post-operative, differentiated according to the existence or non-existence of complaints, examined in the period from 1970 up to and including 1982 ;

5a. comparison of data from patients with a BII- and a BII-stomach, more than 10 years postoperative, examined because of complaints in the period from 1970 up to and including 1979 (group A);

5b. comparison of data from patients with a BI- and a BII-resection stomach, more than 10 years post-operative, examined because of complaints in the period from 1980 up to and including 1982 (group B);

$5 \mathrm{c}$. comparison of data from patients with no symptoms with a BI- and a BII-resection stomach, more than 10 years post-operative, examined for the occurrence of a stump-carcinoma in the period from 1980 up to and including 1982 (group C);

6. the meaning of the symptom haemorrhage as a late post-operative complication with patients with a BII-resection stomach, examined in the period from 1970 up to and including 1982;

7. the meaning of the histological phenomenon of moderate dysplasia as a possible premalignant characteristic of the stump-carcinoma;

8. the meaning of a endoscopicall and histological examination of patients with no symptoms with a BI- and a BII-resection stomach, more than 10 years post-operative;

9. selection of patients with a resection stomach who can be considered for an examination for the occurrence of a stump-carcinoma.

\section{ad. 1 The definition of the stump-carcinoma}

In literature is by stump-carcinoma understood every carcinoma wherever located in the gastric remnant, more than 5 years after the primary operation which took place because of a histologically proved benign disease. Where as to the appearance of the pathogenetical mechanisms from experimental animal research and clinical studies indeed it is not proved, yet it is made acceptable, that the biliary reflux plays a prominent part in the development of the carcinoma of the stoma of the operated stomach, it seems to be significant to make a distinction between carcinomas of the gastric remnant, located at stoma level and carcinomas located elsewhere, par* ticularly at the proximal corpus and the cardia. The stoma-carcinoma may be considered to have developed from changes in the mucous membrane in relationship with the phenomenon biliary reflux, which can be related to the procedure of the primary operation. The carcinomas located elsewhere in the remaining part of the stomach could then be classed in the category of "ordinary stomach carcinomas" , however not to be associated with the phenomenon biliary reflux as far as the origin is concerned. 
Under the plausibility that the stump-carcinoma is frequently seen as a late complication of the BII-resection and that the biliary reflux plays a prominent part in the pathogenesis of this carcinoma located at stoma level, in literature the following advice is given in respect of therapeutics of the peptic ulcer disease: conservative therapeutics with medicines like the histamine II receptorantagonists, or else surgical therapeutics in the sense of a highly selective vagotomy or eventually a resection according to a biliary reflux preventing procedure.

The question arises as to how far clinical distinctions exist between a carcinoma occuring at stoma level and a carcinoma located elsewhere in the remaining part of the stomach. In the study under discussion, 48 carcinomas were diagnosed in the BII-resection stomachs, 2 carcinomas in the BIresection stomachs, more than 10 years after a primary operation because of a benign lesion. Twenty of these 48 carcinomas accurred at stoma level, 18 at the stoma and corpus level, while 10 carcinomas were diagnosed at corpus level. The average age of the patients is: in the category stoma, stoma/corpus and corpus carcinoma successively $69.2,67.4$ and 68.8 year, while the average interwal was calculated for $34.5,33,3$ and 29,4 year.

At stoma level a carcinoma of the intestinal type was found 16 times and one of the diffuse type four times, carcinomas at stoma and corpus level appeared to be of the intestinal type 14 times, four times of the diffuse type, while the corpus carcinoma histologically show the intestinal type seven times and the diffuse type three times.

Equally in respect of the pattern of complaints and the endoscopical and histological pictures there are no clear differences between carcinomas of various locations. Consequently there are no practical consequences for distinguishing carcinomas after their localization in the resection stomach.

\section{ad.2. The frequency of occurrence of the stump carcinoma after a BI-and a BII-resection}

The frequency of occurrence of the carcinoma in the BI- and BIl-resection stomach is given with great fluctuation, ranging from 0.0 to $17.6 \%$, depending on the category of patients examined. Results are mostly given from autopsy statistics, clinical retrospective examination and endoscopical retrospective examination. Frequencies of occurrence of the carcinoma are occasionally given from prospective endoscopical examination, in which examination takes place in different time intervals from the operation, in which the drop out of patients is considerable due to death and refusing to undergo the endoscopical examination.

Because generally the conditions that can be set for the prospective examination are not fulfilled there is barely any reliable information about the frequency of occurrence of the carcinoma in the gastric remnant.

Because of lack of essential information on the population of patients who had a stomach resection in the region of Maastricht in the past, it has not been possible to calculate a frequency of occurrence of the stump-carcinoma with these patients.

From the series of endoscopically and histologically studied patients with a BI- and BII-resection stomach, more than 10 years post-operative, the frequency of occurrence of the carcinoma are calculated for:

- 292 patients with a BII-resection stomach, more than 10 years post-operative, studied because of complaints in the period from 1970 up to and including 1982:34 stump-carcinomas $=11.6 \%$.

- 138 patients with no symptoms with a BII--resection stomach, more than 10 years post-operative, examined on the occurrence of a stump-carcinoma in the period from 1980 up to and including $1982: 5$ stump-carcinomas $=3.6 \%$.

- 38 patients with a BII-stomach resection, more than 10 years post-operative, studied because of stomach-haemorrhage in the period from 1970 up to and including 1982:9 stump-carcinomas $=23.7 \%$.

106 patients with a $\mathrm{BI}$-stomach resection, more than 10 years post-operative, studied in the period from 1970 up to and including 1982, because of complaints: 2 stump-carcinomas = $1.9 \%$

- 43 patients with no complaints with a BI-stomach resection, more than 10 years post-operative, examined on the occurrence of a stump-carcinoma in the period from 1980 up to and including 1982: no stumpcarcinomas $=0.0 \%$.

With a total number of 468 patients with a BII-resection, more than 10 years post-operative, 48 patients were found with a stump-carcinoma $=10.3 \%$.

With a total number of 149 patients with a BI-resection, more than 10 years post-operative, 2 patients were found with a stump-carcinoma $=1.3 \%$. 
ad.3a. Comparison of endoscopical and histological pictures of non-carcinoma patients with a $B I$-resection stomach, more than 10 years post-operative, differentiated according to the existence or non-existence of complaints, examined in the period from 1980 up to and including 1982

When groups of non-carcinoma patients with a BI-resection stomach more than 10 years postoperative, differentiated by complaints or no complaints are compared according to endoscopjcal and histological pictures, for this comparison the group non-carcinoma patients with a BI-resection stomach with complaints from the period 1980 up to and including 1982 and the group non-carcinoma patients with a BI-resection stomach with no complaints from the period 1980 up to and including 1982 will be considered. In this period endoscopial pictures were evaluated according to protocol, for histological examination at least 4 biopsies at stoma level and 4 biopsies at corpus level were taken from the gastric remnant. This was not the case in the period from 1970 up to and including 1979.

The general data from the endoscopical examination of the groups non-carcinoma patients with a BI-resection stomach with and with no complaints are mentioned in Table 12.1.

Tabel 12.1. General endoscopical data of the 49 patients with a BI-stomach with complaints and the 43 pat tients with a BI-stomach with no complaints...

\begin{tabular}{llll}
\hline endoscopical data/ number of patients & $\begin{array}{l}\text { with complaints } \\
\%\end{array}$ & $\begin{array}{c}n o \text { complaints } \\
\% \\
n=43\end{array}$ \\
& & $n=49$ & 97.7 \\
stoma & normal & 98.0 & 2.3 \\
& convergency of folds & 2.0 & 0.0 \\
stomagastritis & stenosis & 0.0 & 11.6 \\
& none & 4.1 & 51.2 \\
& moderate & 55.1 & 37.2 \\
corpusgastritis & severe & 40.8 & 37.2 \\
& none & 36.7 & 53.5 \\
amount of bile & moderate & 51.0 & 9.3 \\
& severe & 12.3 & 53.5 \\
& none & 49.0 & 27.9 \\
suspect stoma & moderate & 38.8 & 18.6 \\
& large & 12.3 & 0.0 \\
\hline
\end{tabular}

Significant differences were not seen with regards to the configuration of the stoma, the frequency and the severity of the stoma and corpus gastritis, the amount of bile at the level of the resection stomach.

When comparing the special features that arose with endoscopical examination (see Table 12.2), the only significant difference is the number of ulcerative/erosive lesions: occurring in the symptomatic group with $16.3 \%$ and in the group with no symptoms with only $2.3 \%$ of the cases $(p<0.05)$. These data are in line with the existence or non-existence of complaints with these groups of patients.

Table 12.2. Special endoscopical findings with the 49 patients with a BI-stomach with complaints and the 43 patients with a BI-stomach with no complaints

\begin{tabular}{|c|c|c|}
\hline endoscopical data/number of patients & $\begin{array}{l}\text { with complaints } \\
\% \\
n=49\end{array}$ & $\begin{array}{l}\text { nocomplaints } \\
\% \\
n=43\end{array}$ \\
\hline $\begin{array}{l}\text { prominent folds stoma } \\
\text { white marks stoma/corpus } \\
\text { duodenal ulcer } \\
\text { stoma ulcer } \\
\text { prestoma ulcer } \\
\text { duodenal/stoma erosion } \\
\text { friable mucous membrane } \\
\text { suspect prestoma area } \\
\text { xantelasmata } \\
\text { polyps }\end{array}$ & $\left.\begin{array}{l}12.2 \\
6.1 \\
8.2 \\
2.0 \\
2.0 \\
4.1 \\
0.0 \\
2.0 \\
8.2 \\
2.0\end{array}\right] 16.3$ & $\begin{array}{l}4.6 \\
7.0 \\
0.0 \\
2.3 \\
0.0 \\
0.0 \\
4.6 \\
0.0 \\
9.3 \\
4.6\end{array}$ \\
\hline
\end{tabular}

*** $\mathrm{p}<0.05$, chi-square-test 
Histological (see Table 12.3) a cystic dilatation of the glandular tubules at stoma level is significantly more often seen with patients with complaints $(p<0.05)$. A mild inflammation of the corpus is significantly more often seen with patients with complaints $(p<0.01)$, while a moderate inflammation of the corpus is significantly more often seen with patients with no complaints $(\mathrm{p}<0.05)$. Otherwise there are no significant differences on histological llevel between these patients with and with no complaints.

Concluding, it can be said that no clear relationship exists between the inflammation and the pattern of complaints. The question arises if , with a number of patients, complaints may be interpreted as caused by a lesion of the stomach.

Tabel 12.3. Data of histological examination of the 49 patients with a BI-stomach with complaints ( 47 stoma and 46 corpus biopsies) and the 42 patients with BI-stomachs with no complaints ( 42 stoma and 42 corpus biopsies).

\begin{tabular}{|c|c|c|c|c|}
\hline & histological data/number of pa & tients & $\begin{array}{l}\text { with complaints } \\
\% \\
n=47 / 46\end{array}$ & $\begin{array}{l}\text { no complaints } \\
\% \\
n=42\end{array}$ \\
\hline \multirow[t]{3}{*}{$\mathrm{s}$} & character mucous membrane & antrum & 31.9 & 16.7 \\
\hline & stoma & corpus & 63.8 & 78.6 \\
\hline & & antrum/corpus & 4.3 & 4.7 \\
\hline \multirow[t]{3}{*}{$\mathrm{T}$} & inflammation stoma & none & 19.1 & 14.3 \\
\hline & & focal & 10.6 & 26.2 \\
\hline & & diffuse & 70.3 & 59.5 \\
\hline \multirow[t]{3}{*}{$\mathrm{O}$} & inflammation stoma & none & 19.1 & 14.3 \\
\hline & & mild & 38.4 & 31.0 \\
\hline & & moderate & 40.4 & 47.6 \\
\hline \multirow[t]{3}{*}{ M } & & severe & 2.1. & 7.1 \\
\hline & cystic dilatation & & 48.9 & $26.2^{* * *}$ \\
\hline & intestinal metaplasia & & 23.4 & 21.4 \\
\hline \multirow[t]{2}{*}{ A } & dysplasia & mild & 36.2 & 33.3 \\
\hline & & moderate & 2.1 & 9.5 \\
\hline \multirow[t]{3}{*}{ C } & inflammation corpus & none & 28.3 & 38.1 \\
\hline & & focal & 17.4 & 23.8 \\
\hline & & diffuse & 54.3 & 38.1 \\
\hline \multirow[t]{3}{*}{$\mathrm{O}$} & inflammation corpus & none & 28.3 & 38.1 \\
\hline & & mild & 45.7 & $11.9^{*}$ \\
\hline & & moderate & 23.9 & $45.2 * * *$ \\
\hline \multirow[t]{3}{*}{$R$} & & severe & 2.1 & 4.8 \\
\hline & cystic dilatation & & 6.5 & 4.8 \\
\hline & intestinal metaplasia & & 8.7 & 14.3 \\
\hline \multirow[t]{2}{*}{$\mathrm{P}$} & dysplasia & mild & 0.0 & 0.0 \\
\hline & & moderate & 0.0 & 0.0 \\
\hline \multirow[t]{2}{*}{$\mathrm{U}$} & atrophic gastritis & & 28.3 & 19.0 \\
\hline & parietal cells & sufficient & 71.7 & 81.0 \\
\hline \multirow[t]{2}{*}{$S$} & & decreased & 15.2 & 9.5 \\
\hline & & absent & 13.1 & 9.5 \\
\hline
\end{tabular}

p $p<0.01{ }^{* * *} \mathrm{p}<0.05$, chi-square-test

ad $3 b$. Comparison of endoscopical and histological pictures of non-carcinoma patients with a $B I$-resection stomach, more than 10 years post-operative, differentiated according to the existence or non-existence of complaints, examined in the period from 1980 up to and including 1982

When groups of non-carcinoma patients with a BII-resection stomach, more than 10 years postoperative, differentiated according to the existence or non-existence of complaints, are compared as far as endoscopical and histological pictures are concerned, then the following groups 
will be considered for comparison: group BII-patients with complaints from the period 1980 up to and including 1982 and the group BlI-patients with no complaints from the period 1980 up to and. including 1982. In this period endoscopical pictures were evaluated according to protocol: for histological examination at least 4 biopsies at stoma level were taken and 4 biopsies at corpus level of the gastric remnant. This was not the case in the period from 1970 up to and including 1979.

The general data of the endoscopical examination of the groups BII-patients with and with no complaints are mentioned in Table 12.4.

Tabel 12.4. General endoscopical data of the 104 patients with a BII-stomach with complaints and the 133 patients with a BII-stomach with no complaints

\begin{tabular}{|c|c|c|c|}
\hline \multicolumn{2}{|c|}{ endoscopicaldata/number of patients } & \multirow{2}{*}{$\begin{array}{l}\text { with complaimts } \\
\% \\
n=104 \\
923\end{array}$} & \multirow{2}{*}{$\begin{array}{l}\text { no complaines } \\
\% \\
n=133 \\
89.5\end{array}$} \\
\hline stoma & normal & & \\
\hline & convergency of folds & 6.7 & 9.0 \\
\hline & stenosis & 1.0 & 1.5 \\
\hline \multirow{3}{*}{ stomagastratitis } & none & 1.0 & 0.0 \\
\hline & moderate & 31.7 & 32.3 \\
\hline & severe & 67.3 & 67.7 \\
\hline \multirow[t]{3}{*}{ corpusgastritis } & none & 29.8 & $11.3^{*}$ \\
\hline & moderate & 57.7 & $74.4^{*}$ \\
\hline & severe & 12.5 & 14.3 \\
\hline \multirow[t]{3}{*}{ amount of bile } & none & 19.2 & 24.8 \\
\hline & moderate & 37.5 & 37.6 \\
\hline & $\operatorname{large}$ & 43.3 & 37.6 \\
\hline
\end{tabular}

${ }^{*} \mathrm{p}<0.011$, chi-square-test

It appears that significantly more often a corpus-gastritis is not found with patients with complaints $(\mathrm{p}<0.01)$, a moderate serious gastritis is significantly more often seen with patients with no complaints than with patients with complaints $(p<0.01)$. It can be specified that there is no clear relationship between the existence or non existence of complaints and the occurrence of a stoma and corpus gastritis. On comparing the particularities determined on endoscopical examination (see Table 12.5), it becomes evident that ulcerative/erosive lesions are significantly more frequently seen with symptomatic patients than which patients with no symptons with a BII-resection stomach $(p<0.01)$.

This fact is positively correlated to the existence of complaints. Apart from that there are only a few significant differences in the endoscopical pictures of both groups of patients.

Tabel 12.5. Special endoscopical findings with the 104 patients with a BII-stomach with complaints and the 133 patients with $\mathrm{B}$ BI-stomach with no complaints

\begin{tabular}{lll}
\hline endoscopicaldata/mumber of patients & $\begin{array}{c}\text { with complaints } \\
\%\end{array}$ & $\begin{array}{c}n \text { nocomplaints } \\
\% \\
n=1.33\end{array}$ \\
\hline prominent folds stoma & $n=104$ & 6.8 \\
jejunal mucous membrane on stoma & 14.4 & 6.0 \\
white marks stoma/corpus & 8.6 & 9.1 \\
jejunal ulcer & 9.6 & 1.5 \\
stoma ulcer & 7.7 & 0.0 \\
prestoma ulcer & 1.9 \\
jejunall erosion & 0.9 & 0.7 \\
suspect prestoma ulcer & 0.9 & 0.0 \\
xantelasmata & 0.9 & 0.0 \\
adenomatous tissue & 7.7 & 12.0 \\
friable mucous membrane stoma & 0.0 & 1.5 \\
polyps & 0.0 & 2.3 \\
oesophagitis & 0.0 & 3.0 \\
\hline
\end{tabular}

* p 00.01 , chil-square-test 
On comparing the pictures on histological level (see Tabel 12.6) a focal inflammation at corpus level seems to occur significantly more frequently with patients with no complaints $(\mathrm{p}<0.02)$.

The same can be applied to the histological phenomenon intestinal metaplasia of the corpus $(\mathrm{p}<0.02)$. No clear relationship can be seen between the existence or non-existence of complaints and abnormalities at histological level.

Tabel 12.6 Data on histological examination of the 104 pitients with a BII-stomach with complaints (104 stoma and 103 corpus biopsies) and the 133 patients with a BII-stomach with no complaints (133 stoma and 133 corpus biopsies)

\begin{tabular}{|c|c|c|c|c|}
\hline & histological data/rumber of pa & itients: & $\begin{array}{l}\text { with complaints } \\
\% \\
n=104 / 103\end{array}$ & $\begin{array}{l}\text { no complaints } \\
\% \\
n=1.33\end{array}$ \\
\hline \multirow[t]{3}{*}{$\mathrm{s}$} & character mucous membrane & antrum & 44.2 & 47.4 \\
\hline & stomat & corpus & 50.0 & 48.9 \\
\hline & & antrum/corpus & 5.8 & 3.7 \\
\hline \multirow[t]{3}{*}{$\mathrm{T}$} & inflammation stomat & none & 9.6 & 18.0 \\
\hline & & focal & 20.2 & 21.2 \\
\hline & & diffuse & 70.2 & 60.9 \\
\hline \multirow[t]{3}{*}{0} & inflammation stoma & none & 9.6 & 18.0 \\
\hline & & mild! & 40.4 & 42.2 \\
\hline & & moderate & 38.5 & 33.8 \\
\hline \multirow[t]{3}{*}{ M } & & severe & 11.5 & 6.0 \\
\hline & cystic dilatation & & 70.2 & 74.4 \\
\hline & intestinal metaplasia & & 16.3 & 21.8 \\
\hline \multirow[t]{2}{*}{ A } & dysplasia & milld & 45.2 & 53.4 \\
\hline & & moderate & 7.7 & 6.8 \\
\hline \multirow[t]{3}{*}{$\overline{\mathrm{C}}$} & inflanmation corpus & none & 28.2 & 21.8 \\
\hline & & focal & 13.6 & $26.3^{* * 4}$ \\
\hline & & diffuse & 58.2 & 51.9 \\
\hline \multirow[t]{3}{*}{ O } & inflammation corpus & none & 28.2 & 21.8 \\
\hline & & mnild & 27.2 & 27.8 \\
\hline & & moderate & 35.9 & 38.3 \\
\hline \multirow[t]{3}{*}{$\mathrm{R}$} & & severe & 8.7 & 12.1 \\
\hline & cystic dilatation & & 12.6 & 10.5 \\
\hline & intestinal metaplasia & & 10.7 & $23.3^{* * *}$ \\
\hline \multirow[t]{2}{*}{$\mathrm{P}$} & dysplasia & mild & 8.7 & 6.0 \\
\hline & atrophic gastritis & & 29.1 & 36.8 \\
\hline \multirow[t]{3}{*}{$\mathrm{U}$} & parietal cells & sufficient & 68.0 & 57.9 \\
\hline & & decreased & 18.4 & 29.3 \\
\hline & & absent & 13.6 & 12.8 \\
\hline
\end{tabular}

" p<0,02, chi-square-test

ad. 4a. Comparison of frequency of occurrence of the stump-carcinoma and the prognosis of the stump carcinoma of patients with , BI-resection stomach, more than 10 years post-operative, differentiated according to the existence or non-existence of complaints, examined in the period from 1970 up to and including 1982

When comparing the frequency of occurrence of the stump-carcinoma and the prognosis of the stump-carcinoma, the group of patients with a BI-resection stomach from the period 1970 up to and including 1979 , is implicated too. When comparing the findings, the fact is taken into account that the period of examining of the group of patients with complaints is spread over a period of 13 years, and the period of examining of the group with no complaints is spread over a period of 3 years. With the patients with a BI-resection stomach, more than 10 years post-operative, examined because of complaints in the period from 1970 up to and including 1982, a stump-carcinoma was found twice. With patients with no symptoms, examined on the occurrence of a stump-carcinoma in the period from 1980 up to and including 1982, no stump-carcinoma was diagnosed. It can be specified that in the period from 1970 up to and including 1982 , the frequency of occurrence of the stump-carcinoma in the BI-resection stomach is small, this frequency is $1.9 \%$ with those patients $(n=106)$ examined because of complaints, $1.3 \%$ of the total group of patients with a Bl-resection stomach $(n=149)$, examined during this period. The prognosis of 
both the symptomatic patients with a stump-carcinoma appeared to be extremely bad, one month after the diagnosis was set both patients died.

ad. $4 b$ Comparison of frequency of occurrence of the stump-carcinoma and the prognosis of the stump-carcinoma of patients with a BII-resection stomach, more than 10 years post-operative, differentiated according to the existence or non-existence of complaints, examined in the period from 1970 up to and including 1982

When comparing the frequency of occurrence of the stump-carcinoma and the prognosis of the stump-carcinoma, the group of patients with a BII-stomach from the period from 1970 up to and including 1979 , is involved too. It is taken into account that the period of examining the patients with complaints is spread over a period of 13 years, and the period of examining the patients with no complaints over 3 years. With 292 patients with a BII-resection stomach, more than 10 years post-operative, examined because of complaints in the period from 1970 up to and including 1982, a stump-carcinoma was diagnosed 34 times: $11.6 \%$. In the period from 1970 up to and in. cluding 1979,20 stump-carcinomas were diagnosed with 174 patients $(11.5 \%)$, in the period from 1980 up to and including 1982, a stump-carcinoma was diagnosed 14 times with 118 patients: $(11.8 \%)$.

With 138 patients with no complaints a stump-carcinoma was diagnosed 5 times: $(3.6 \%)$ in the period from 1980 up to and including 1982. On comparing these percentages of stump-carcinomas in the period from 1980 up to and including 1982, it becomes evident that the percentage is $11.8 \%$ with symptomatic patients and $3.6 \%$ with patients with no symptoms. The difference is significant $(\mathrm{p}<0.02)$.

With regards to the problem of the prognosis, the data of the 34 symptomatic patients with a stump-carcinoma are mentioned under Table 12.7. There seems to be clear correlation between the extent of the malignant process and the period of surviving. With the 5 patients with no symptoms with a stump-carcinoma it turned out to be an early gastric-carcinoma in all five cases. One patient died post-operative as a result of a lung-embolism, one patient committed suicide in a depressive mood. The three other patients are alive in a general good condition. The average period of survival of these three patients is so far (February 1983) 13 months.

There seems a clear difference of prognosis: with patients with symptomatic stump-carcinoma the prognosis is mostly bad because of the extent of the process, with patients with a stump-carcinoma at the stage when there are no symptoms, it is often a case of an early carcinoma of which the prognosis, after intended curative surgical intervention, is good.

Table 12.7 Different ways of treatment and their corresponding period of survival of 34 symptomatic pa* tients with a stump-carcinoma

\begin{tabular}{|c|c|c|c|c|c|c|}
\hline form of treatmont & $\begin{array}{l}\text { total number } \\
\text { of patients }\end{array}$ & $\begin{array}{l}\text { mean period } \\
\text { of survival in } \\
\text { months }\end{array}$ & $\begin{array}{l}\text { number of } \\
\text { deceased } \\
\text { patients }\end{array}$ & $\begin{array}{l}\text { mean period } \\
\text { of survival } \\
\text { in months }\end{array}$ & $\begin{array}{l}\text { number of } \\
\text { patients } \\
\text { still alive }\end{array}$ & $\begin{array}{l}\text { meanperiod } \\
\text { of survival } \\
\text { in months }\end{array}$ \\
\hline $\begin{array}{l}\text { sub-total } \\
\text { stomach-resection } \\
\text { restricted }\end{array}$ & 5 & 47.6 & 2 & 75.0 & 3 & 29.3 \\
\hline stomach resection & 4 & 23.2 & 4 & 23.2 & . & - \\
\hline $\begin{array}{l}\text { inoperable } \\
\text { nooperation }\end{array}$ & 11 & 5.5 & $\mathbb{1}$ & 5.5 & - & - \\
\hline $\begin{array}{l}\text { because of process } \\
\text { no operation }\end{array}$ & 6 & 1.2 & 6 & 1.2 & . & 。 \\
\hline $\begin{array}{l}\text { because of age } \\
\text { died }\end{array}$ & 6 & 18.8 & 4 & 17.5 & 2 & 21.5 \\
\hline post-operative & 2 & . & - & - & - & - \\
\hline
\end{tabular}

* extent of process and/or metastasis

ad 5 a Comparison of data from patients with a BI- and a BII-resection slomach, more than 10 years post-operative, examined because of complaints in the period from 1970 up to and including 1979 (group A) 
When information from examining the groups of patients with a BI-and BII-stomach resection, examined in the period from 1970 up to and including 1979, is compared, it appears that a stumpcarcinoma proportionally occurred more frequently with patients with a BII-resection stomach (BI-stomach: $3.5 \%$, BIl-stomach: 11.5\%). The difference does not seem to be significant with these small numbers of stump-carcinomas. The groups are well comparable with regards to the mean age and the mean interval

Histological intormation about the groups of non-carcinoma patients with a BI-and a BII-resecfion stomach is being compared, in order to check if there are differences which are possibly relevant with regard to the problem of the frequency of occurrence of the stump-carcinoma in the BI- thind the BII-stomach.

It involves 55 patients with a BI-stomach (the mean age is 57.3 years; the mean interval 19.3 years), 154 patients with a BIImstomach (mean age 57.4 years; mean interval 22.8 years).

Tatble 12.8 Comparison of the data of the examination of the 55 non-carcinoma patients with a BI-stomach ( 54 stoma and 50 corpus biopsies) and the 154 non-carcinoma patients with a BII-stoma (149 stoma and 145 corpus biopsies)

\begin{tabular}{|c|c|c|c|}
\hline data of examination/number of patients & $\begin{array}{l}(\%) \\
n=54 / 50\end{array}$ & $\begin{array}{l}\text { BI-stomach } \\
(\%) \\
n=149145\end{array}$ & BII-stomach \\
\hline character mucous membrane stoma: & $\begin{array}{l}\text { antrum } \\
\text { corpus }\end{array}$ & $\begin{array}{l}20.4 \\
77.8\end{array}$ & $\begin{array}{l}43.8^{*} \\
51.7^{*}\end{array}$ \\
\hline stomagastritis & $\begin{array}{l}\text { mild } \\
\text { moderate }\end{array}$ & $\begin{array}{l}37.0 \\
55.6\end{array}$ & $\begin{array}{l}46.3 \\
43.6^{* * * *}\end{array}$ \\
\hline cystic dilatation gland-tubules stoma & & 58.2 & 73.1 \\
\hline intestinal metaplasia stoma & & 7.3 & 14.11 \\
\hline dysplasiata stomá & $\begin{array}{l}\text { mild } \\
\text { moderate }\end{array}$ & $\begin{array}{r}16.7 \\
1.8\end{array}$ & $\begin{array}{r}26.2 \\
2,0\end{array}$ \\
\hline corpusgastritis & mild & $\begin{array}{l}40.0 \\
360\end{array}$ & $\begin{array}{l}46.2 \\
32.4\end{array}$ \\
\hline intestinal metaplasiáa corpus & & 6.0 & 9.0 \\
\hline dysplasia corpus & mild & 0.0 & 2.8 \\
\hline atrophic gastritis corpus & & 36.0 & 26.9 \\
\hline
\end{tabular}

"p<0.01*** p p $<0.05$, chisquare-test

When comparing the data (see Table 12.8) then the stoma mucous membrane of the antrum character is significantly more often seen with the group BII-stomach than with the group BIstomach $(\mathrm{p}<0.01)$; intestinal metaplasia at stoma level appears twice as frequently with the group BII-stomach than with the group BI-stomach, the difference is not significant. Cystic dilataltion of the glandular tubules appears less frequently at stomat level with patients with a BIstomach than with patients with a Bll-stomach. This difference is not significant.

No answer can be given from the present data to the question why the stump-carcinoma occurs three times as much with patients with a BII-stomach as with patients with a BI-stomach. One could wonder if the double frequency of appearance of the antrum mucous membranc at stoma level of the patients with a BII-stomach has any significance. Does the mucous membrane of the BII-stomach change more frequently than that of the B -stomach from corpus into antrum type under the influence of biliary reflux? Does this increase the possibility of a stump-carcinoma through contimuous irritation by biliary reflux? This question can not be answered, not even with data from literature.

ad 5 b. Comparison of data from patients with a $B I$-and a $B I$-resection stomach, more than 10 years post-operative, examined because of complaints in the period from 1980 up to and including 1982 (Group B)

When comparing information from examining patients with a BI-and a BII-resection stomach, examined because of complaints in the period from 1980 up to and including 1982, it becomes evident that a stump-carcinoma occurres significantly more frequently with patients with a BIIstomach $(\mathrm{p}<0.02)$. The groups are well comparable with regard to mean age and mean interval. Information about the groups non-carcinoma patients with a Bl-and a BII-stomach is being compared, in order to check if there are differences which are possibly relevant to the problem of the frequency of occurrence of the stump-carcinoma in the BI- and the BII-stomach. It concerns 49 
patients with a BI-stomach (mean age 61.5 years, interwal 20.7 years) and 104 patients with a BI. stomach (mean age 62.0 years, mean interval 26.1 years).

Table 12.9 Comparison of the data of the examination of the 49 non carcinoma patients with a BI-stomach (47 stoma and 46 corpus biopsies) and the 104 non-carcinoma patients witli a BII-stomach (104 stoma and 103 corpus biopsies)

\begin{tabular}{|c|c|c|c|}
\hline data of examination/number of patients & & $\begin{array}{l}\text { BI-sromach } \\
(\%) \\
n=47 / 46\end{array}$ & $\begin{array}{l}\text { BH-sromach } \\
(\%) \\
n=104 / 103\end{array}$ \\
\hline character mucous membrane stoma & $\begin{array}{l}\text { artrum } \\
\text { corpus }\end{array}$ & $\begin{array}{l}31.9 \\
63.8\end{array}$ & $\begin{array}{l}44.2 \\
50.0^{* * *}\end{array}$ \\
\hline stomagastritis & mild & 38.4 & 40.4 \\
\hline $\begin{array}{l}\text { cystic dilatation gland-tubules stoma } \\
\text { intestinal metaplasia stoma }\end{array}$ & & $\begin{array}{l}48.9 \\
23.4\end{array}$ & $\begin{array}{l}70.2^{* *} \\
16.3\end{array}$ \\
\hline dysplasia stoma & $\begin{array}{l}\text { mild } \\
\text { moderate }\end{array}$ & $\begin{array}{r}36.2 \\
2.1\end{array}$ & $\begin{array}{r}45.2 \\
7.7\end{array}$ \\
\hline corpus gastritis & $\begin{array}{l}\text { mild } \\
\text { moderate }\end{array}$ & $\begin{array}{l}45.7 \\
23.9\end{array}$ & $\begin{array}{l}27.2^{* * 48} \\
35.9\end{array}$ \\
\hline intestinal metaplasia corpus & & 8.7 & 10.7 \\
\hline dysplasia corpus & mild & $\begin{array}{r}0.0 \\
28.3\end{array}$ & $8,7^{* * 4 *}$ \\
\hline $\begin{array}{l}\text { atrophic gastritis corpus } \\
\text { amount of bile in gastric remnant }\end{array}$ & moderate & $\begin{array}{l}28.3 \\
38.8 \\
12.2\end{array}$ & $\begin{array}{l}29.1 \\
37.5 \\
43.3\end{array}$ \\
\hline
\end{tabular}

* $p<0.01 * * 0<0.02 * * * 0<0.05$, chi-square-test

On comparing the data (see Table 12.9) some clear differences are apparent. Mucous membrane of the character of the corpus is significantly more often seen at stoma level with the BI-stomach $(p<0.05)$, dilatation of the glandular tubules at stoma level is significantly more often seen with the BII-stomach $(p<0.02)$. A mild inflammation of the corpus is significantly more often seen with the BI-stomach ( $\mathrm{p}<0.05$ ), a mild dysplasia of the corpus-epithelium is significantly more frequent with the BII-stomach $(\mathrm{p}<0.05)$.

A large amount of bile appears significantly more often with the BII-stomach $(p<0.01)$. Informa* tion from literature (animal-experimental-research by Dahm and Werner 1973, Langhans a.o. 1980) support the supposition, that a relationship exists between the severity of the biliary reflux in the gastric remnant and the to this positively correlated risk of development of a stumpcarcinoma.

The hypotheses that as a result of a less severe biliary reflux in the BI-resection stomach a stumpcarcinoma would develop on a much longer period, that under the influence of a biliary reflux the mucous membrane of the stoma would change from a corpus type into a antrum type, which would then mean a greater risk of a stump-carcinoma through continuous irritation by biliary reflux, are speculative. Opinions differ about the meaning of a moderate dysplasia as a precancerous condition of the resected stomach.

ad $5 \mathrm{c}$ Comparison of data from patients with no symptoms with a BI- and a BII-resection stomach, more than 10 years post-operative, examined for the occurrence of a stump-carcinoma in the period from 1980 up to and including 1982 (group C)

When the information about patients with no symptoms with a BI-resection stomach and with a BII-resection stomach, examined in the period from 1980 up to and including 1982, after the same procedure on the existence of a stump-carcinoma, is compared, it become evident that a stump-carcinoma actually exists in the BII-stomach ( 5 out of 138 patients) and does not exist in the BI-stomach (0 out of 43 patients). The difference is not significant. The groups are wel comparable with regard to the mean age and the mean interval. The data about the groups non-carcinoma patients with a BI-stomach and a BII-stomach are being compared in order to check if there are differences which may be relevant to the problem of the frequency of occurrence of the stump-carcinoma in the BI- and the BII-stomach. It concerns 43 patients with a BI-stomach (mean age 61.4 years; mean interval 23.0 years) and 133 patients with a BII-stomacl (mean age 61.9 years; mean interval 25.4 years). 
Trbel 12.10 Comparison of the data resulting from the examination of the 42 non-carcinoma patients with a BI-stonach ( 42 stoma and 42 corpus biopsies) and the 133 non-carcinoma patients with a BII stomach (133 stoma and 133 corpus biopsies)

\begin{tabular}{llll}
\hline data of examination/mumber of patients & & $\begin{array}{l}\text { BI-stomach } \\
(\%) \\
n=42\end{array}$ & $\begin{array}{l}\text { BH-stomach } \\
(\%) \\
n=133\end{array}$ \\
\hline character mucous membrane stoma & antrum & 1.6 .7 & $47.4^{*}$ \\
stoma gastritis & corpus & 78.6 & $48.9^{*}$ \\
cystic dilatation & mild & 31.0 & 42.2 \\
gland-tubules stomat & moderate & 47.6 & 38.8 \\
intestinal metaplasia stomat & & 26.2 & $74.4^{*}$ \\
dysplasia stomia & & 21.4 & 21.8 \\
& mild & 33.3 & $53.4^{* * *}$ \\
corpus gastritis & moderate & 9.5 & 6.8 \\
intestinal metaplasia corpus & mild & 11.9 & $27.8^{* * *}$ \\
dysplasia corpus & moderate & 45.2 & 38.3 \\
atrophic gastritis corpus & & 14.3 & 23.3 \\
amount of bile in gastric & mild & 0.0 & 6.0 \\
rennant & & 19.0 & $36.8^{*}$ \\
& & 27.9 & 37.6 \\
\hline
\end{tabular}

* $p<0.01$ ** $p<0.02$ ** * $p<0.05$, chi-square test

On comparing the results (see table 12.10 ) some significant differences are apparent. Mucous membrane of the antrum character is significantly more often seen at stoma level of the BlIstomach $(p<0.01)$, mucous membrane of the corpus character at stoma level of the BI-stomach $(p<0.01)$. Cystic dilatation of glandular tubules is significantly mote often seen at stoma level of the BII-stomach ( $p<0.01)$; the same is valid for the phenomenon mild dysplasia $(p<0.05)$. A mild inflammation of the corpus and atrophic gastritis too are significantly more often diagnosed with patients with a BII-stomach $(\mathrm{p}<0.05)$. With endoscopy, a large amount of bile is significantly more often diagnosed with patients with a BII-stomach $(p<0.05)$.

Information from literature (animal-experimental-research Dahm and Werner 1973, Langhans a.o. 1980) support the supposition that a relationship exists between the severity of the biliary reflux in the resection stomach and an enhanced risk of a stump-carcinoma. The hypotheses that under the influence of the biliary reflux the mucous membrane of the stoma would change from at corpus type into an antrum type, that the antrum mucous membrane would be predisposed to the development of a stumpcarcinoma when continuously irritated by biliary reflux, are speculative. A moderate dysplasia at stoma level, by some people regarded as a premalignant condition, occurs in this series as frequently with patients with a Bl-resection stomach as with patients with a Bll-resection stomach (including the 5 patients with a stump-carcinoma). This information might militate against the theory, that the phenomenon moderate dysplasia is premalignant.

ad. 6. The meaning of the symptom haenorrhage as a late post-operativce complication with patients with a BII-resection sromach, examined in the period from 1970 up to and including 1982

In the period from 1970 up to and including 1982, 51 patients with a BII-resection stomach were endoscopical examined because of symptoms of a haemorrhage of the upper digestive tract. The primary operation took place with 38 patients, more than 10 years before the examination. With 9 of the 38 patients $(23.7 \%)$ a stump carcinoma was diagnosed endoscopically and histologically. Six of the 9 carcinomatpatients had no complaints of losing appetite, weight loss, pyrosis, belching, nausea, vomiting or pain. Fifteen of the 42 non-carcinoma patients $(35.7 \%$ ) had no complaints either.

When looking into the anamnesis for facts which may be a possible cause for the haemorrhage, such as anticoagulant therapy, the use of analgetics, allcoholabuse and the like, with one of the 9 carcinoma patients (1.1.1\%) and with 18 of the 42 non-carcinoma patients (42.8\%), a potential cause for the haemorrhage was found there. 
With the operation it became ewident that the carcinoma was inoperable with 2 patients, a resection was carried out 5 times. Two patients were not operated on because of an advanced age and a not good general condition in one case, the age and the extent of the process in the other case. Two patients died as a consequence of complications of the operation, 4 patients died after an average period of 13.5 months $(4,8,18$ and 24 months), 3 patients are still alive in February 1983 , after an average period of 24.3 months. The prognosis of the group of patients therefore is bad, but seems somewhat better than the prognosis of the patients with whom a stump-carcinoma was diagnosed because of complaints such as losing appetite and considerable weightloss. When therefore with patients with a BlI-resection stomach, more than 20 years post-operative, a haemorrhage occurs, the possibility of a carcinoma in the gastric remnant should be considered, certainly when no potential cause is found for the haemorrhage in the anamnesis.

\section{ad. 7. The meaning of the histological phenomenon of moderate dysplasia as a possible premalig- nant characteristic of the stump-carcinoma}

Because of the question if the phenomenon moderate dysplasia at stoma level has any significance as a precancerous condition in the resected stomach, the various series of patients with a BI- and BII-resection stomach were examined for the existence of a moderate dysplasia at stoma level.

The frequency of occurrence may be expressed as follows:

(patients with and with no carcinomas in the gastric remnant are mentioned separately)

- group BII-patients with complaints, period 1970 up to and including 1979:

o 149 non-carcinoma patients: three times moderate dysplasia $=2.0 \%$

- 20 carcinoma patients: three times moderate dysplasia $=15.0 \%$

Remark: with 11 carcinoma patients the stoma can not be assessed (because diffuse infiltration of the carcinoma, 7 times; because of lacking information, 4 times);

- group BII-patients with complaints, period 1980 up to and including 1982:

o 104 non-carcinoma patients, 8 times moderate dysplasia $=7.7 \%$

o 14 carcinoma patients: twice moderate dysplasia $=14.3 \%$

Remark: stoma can not be assessed with 4 carcinoma patients (diffuse infiltration by carcinoma);

- group BII-patients with no complaints, period 1980 up to and including 1982:

o 133 non-carcinoma patients: nine times moderate dysplasia $=6.8 \%$

- 5 carcinoma patients: four times moderate dysplasia $=80.0 \%$;

- group BII patients with haemorrhage, period 1970 up to and including 1982:

o 34 non-carcinoma patients: none moderate dysplasia $=0.0 \%$

o 9 carcinoma patients: twice moderate dysplasia $=22.2 \%$

Remark: with three carcinoma patients the stoma could not be assessed (no information);

- group BI-patients with complaints, period 1970 up to and including 1979:

o 54 non-carcinoma patients: one moderate dysplasia $=1.8 \%$

o 2 carcinoma patients: one moderate dysplasia $=50.0 \%$

Remark: with one patient the stoma could not be assessed (diffuse infiltration by carcinoma);

- group BI-patients with complaints, period 1980 up to and including 1982:

o 47 non-carcinoma patients: one moderate dysplasia $=2.1 \%$;

- group BI-patients with no complaints, period 1980 up 10 and including 1982 :

o 42 non-carcinoma patients: four moderate dysplasia $=9.5 \%$.

It should be noted that in the period from 1970 up to and including 1979, fewer biopsies were taken at stoma level, which might be a reason for the diagnosis of only a small number of moderate dysplasia at stoma level in that period.

Calculated over the 420 non carcinoma patients with a BII-resection stomach, a moderate dysplasia is seen 20 times $(4.8 \%)$; with the 48 carcinoma patients with a BII-resection stomach, moderate dysplasia is diagnosed 11 times $(22.9 \%)$, but it should be noted that the stoma could not be assessed 18 times (diffuse infiltration by carcinoma, 11 times; no histological information, 7 times).

With the 104 non-carcinoma patients with a BI-resection stomach a moderate dysplasia at stoma level was diagnosed six times $(4.2 \%)$; with the 2 carcinoma patients with a BI-resection stomach a moderate dysplasia at stoma level occurred once; due to diffuse infiltration of stoma by the carcinoma tissue this phenomenon could not be assessed in one case. 
With the 20 non-carcinoma patients with a BII-resection stomach, with whom a moderate dysplasia at stoma level was diagnosed, an endoscopical control examination took place with 11 patients after approximately one year, in the course of which a moderate dysplasia occurred again in six cases $(54.4 \%)$, in five cases there was no such funding. The other patients have refused until now to undergo this control-examination. Among them are 3 patients with whom the first examination took place 7,11 and 12 years ago. These patients have no complaints and are in a good general condition.

With four of the six patients with a BI-resection stomach, with whom a moderate dysplasia at stoma level was diagnosed, a control endoscopical examination took place in approximately one year, in the course of which a dysplasia occurred again twice $(50.0 \%)$, absence of this phenomenon was diagnosed twice. The other two patients have refused to undergo this control-examination until now.

Although no definite opinion based on this material can be given in respect of the histological phenomenon moderate dysplasid, the following information arose from this examination:

- the phenomenon moderate dysplasia occurred almost equally at stoma level with the BI- as with the BII-resection stomach;

- the phenomenon moderate dysplasia is more often seen at stoma level with patients with a car. cinoma in the gastric remnant that with patients with no carcinoma;

- in order to diagnose the phenomenon moderate dysplasia at stoma level, multiple biopsies should be taken;

- with a control examination of patients with a moderate dysplasia at stoma level, the phenomenon was again diagnosed with only half the number of patients;

the phenomenon moderate dysplasia cannot simply be regarded as a precancerous condition.

\section{ad. 8. The meaning of endoscopical and histological examination of patients with no symptoms with a $B I$-and BII-resection stomach, more than 10 years post-operative}

In order to make a curative treatment of the carcinoma in the gastric remnant possible, this carcinoma should be diagnosed at an early stage. This seems possible when examining patients with no complaints, and a skilled endoscopist closely examining the stomach especially on minor changes of the mucous membrane and taking multiple biopsies for histological examination.

In order to make it possible to give an answer to the question if it is attainable to screen the patients with a resection-stomach, the conditions to which the early diagnostic should apply must be looked upon (van Es 1980):

- secondary prevention should improve the prognosis or the chance of surviving, or should reduce the disadvantages to be expected of the disease;

- the examination required should be easy to accept and hardly burdening for the patients; the examination should involve no risks for the patients;

- risks and disadvantages of a possible treatment should be in proportion to the advantages which may be gained;

early symptoms must lead with great certainty to the development of the disease within measurable time;

- if screening should be applied the disease should have such a frequency that the result can be called reasonable in extent, or so serious that the discovery will have very important consequences;

- for the examination should a method be available which is both sensitive and specific;

- it must be claimed that the cost (material and man-power) should be in proportion to the other costs of health care and in balance with the total budget; it can also be required that the cost and benefit should be in balance.

When these conditions are consecutively taken into further consideration, it may be commented:

- from our examination it appears that the chances of survival of patients curatively operated on because of a carcinoma in the gastric remnant, which was diagnosed at an early stage, seem to be considerably improved, compared to the chances of survival of the patients of whom the diagnosis was made in the symptomatic stage. Considering the fact that the progression of the stomach carcinoma in the premalignant stage should probably be measured in decades, in the early stage in years and in the last stage in months, it should be remarked that patients with a carcinoma in an early stage may well live in all probability for years without complaints, also if they are not operated. The five years period of survival is significantly better after operation of 
the carcinoma in an early stage (carcinoma limited to the mucosa/submucosa) than after an operation in the advanced stage.

- An endoscopical examination seems rather burdening and not easy to accept for a number of patients, in a sence, that they rather dread it, due to stories from friends, neighbours and other people. These patients are often rather restless during the examination and retch regularly, which makes the examination for them quite unpleasant compared to the patients who undergo the examination in a relaxed state. Informing the patient about the examination and the appli cation of light sedatives may reduce the unpleasant effects of the examination. In the scheme of the examination of patients with no symptoms, for a carcinoma in the gastric remnant, more than 10 years post-operative, the G.P.'s were informed by means of a letter, about the character and the purposes of the examination. It was left with them to select patients for this examination and to inform them about the background of this examination. The number of patients who refused the examination after this conversation with the G.P., is not known. "The patients who had this examination, in general did not find the experience too unpleasant. Negative reactions were received twice: one of not being unformed about the procedure of taking biopsies (stomach complaints after the examination, find himself in the roll of a patient), one with regard to the financial aspect of the examunation. In general it can be said that endoscopical examination of the stomach cannot be qualified as being a great burden or as not easily acceptable to patients.

- The hazards of the gastroscopy are small in general. The only risk with the set procedure seems to be the chance of a considerable haemorrhage afterwards. This problem occurred with 5 of the 630 endoscoped patients $(=0.79 \%)$, it was necessary twice to hospitalize a patient $(0.32 \%)$. Though it may be said that the risk of somatization is present with patients with no complaints, when they are confronted with the information of a possible lesion of the stomach or a possible development of it in the near future, the only alternative to avoid this risk utterly seems to be the ostrich-policy.

- Risks and disadvantages of the surgical therapeutics that will be instituted seem to be in proportion with the advantages that will be gained, when on selecting the patients the dangers of a possible operative procedure are taken into account and patients with a high risk are excluded.

- When histological characterising features, indicating the existence of a carcinoma are valid as early symptoms, then it can be said that in this case there will be symptoms of the disease such as losing appetite, weightloss, belching, nausea, vomiting or pain, etc. within measurable time. - When the population of patients to be screened, with a resection stomach can be clearly selected, on grounds of available criteria, from the great number of patients that had a stomach operation, the frequency of occurrence of the stump-carcinoma with this group will, in all probability, be high enough to call the results of this examination reasonable. Anyway the severity of the lesion is such that diagnosing it has important consequences.

- Endoscopy is a sensitive examining methodology as far as lesions suspect for a malignant process can be ascertained macroscopically by a skilled endoscopist, in which by histological examination of taken biopsies, the diagnosis carcinoma can be confirmed by a skilled pathologistanatomist. However, carcinomas in an early stage can more often not be recognized endoscopically-macroscopically and multiple biopsies must be taken. Histological examination can only bring the diagnosis early carcinoma when the biopsies are taken of the "right" spot. Therefore a combination of factors (an experienced endoscopist and pathologist-anatomist, the number of biopsies taken) conditions the sensitiveness of this examniation. The specificness of the examination (endoscopy and histology) appears to be good.

- When careful selection is carried out according to available criteria, it secms that the requirements, costs should be in proportion with other costs of health care, should be in balance with the total budget, can be met. With regard to the demand that cost and benefit should be in balance, it should be suggested that it cannot be assessed to what degree this requirement can be met, as long as it is not clear what negative aspects screening has in the sence of somatization of patients with no complaints untill now etc.

Regarding all the conditions for admissible screening of patients with a resection stomach with no complaints, it seems not possible to meet the requirements easily. The limited knowledge about the natural course of the stump-carcinoma due to the lack of long-range follow-up studies of nonoperated patients and of the as precancerous regarded conditions, makes it almost impossible to assess the usefulness of screening. 
Examination of patients with a resection-stomach with no complaints offers the only possibility to diagnose the carcinoma at a curative stage. It seems to be reasonable to check if there are valid criteria on the grounds of which patients can be selected for this examination.

- The results of our study indicate that a carcinoma of the resection stomach is significantly more often seen with patients with a BII-resection stomach than with patients with a BI-resection stomach. Therefore the BII-resection stomach seems to run a greater risk to develop a stumpcarcinoma.

- Because of the bad prognosis of the carcinoma in the operated stomach, diagnosed in the symptomatic stage, in literature the advice is given to examine patients with a resection stomach, from 10 years post-operative regularly, endoscopically and histologically. Because the interval between the operation and the diagnosis of the carcinoma of the operated stomach has an average of 30 years, it seems that the point of time to start the examination, 10 years post-operative, is too soon. In that case examination would be carried out too frequently on patients who at that point run little risk. This involves high costs on one hand, and on the other hand, the possibility that patients who had an endoscopical examination several times, refuse to have another one at a stage where the chance of a carcinome is clearly increased. In order to set the best possible time for the examination to take place, the results of the examination were statistically arranged.

Three patient groups were studied:

- 292 patients with a BII-stomach, examined because of complaints in the period from 1970 up to and including 1982, with this group 34 carcinomas were diagnosed (group C);

- 51 patients with a BII-stomach, examined because of the symptom haemorrhage in the period from 1970 up to and including 1982, with this group 9 carcinomas were diagnosed (group $\mathrm{H}$ );

- 138 patients with a BII-stomach with no complaints, examined in the period from 1980 up to and including 1982, with this group 5 carcinomas were diagnosed (group NC).

With the groups $\mathrm{C}$ and $\mathrm{H}$ most of the carcinomas were diagnosed in a late stage, the prognosis of these patients proved to be bad.. Naturally it cannot be determined when these carcinomas were in an early stage and could still have been treated curatively. The starting-point for the calculation of the time for the examination on an early carcinoma was therefore group $\mathrm{NC}$, with which all carcinomas were diagnosed at an early stage. Table 12.11 indicates the mean tumourfree time with the standard-error, based on tumour-free survival curves for the groups $\mathrm{C}, \mathrm{H}$ and NC. Because the longest tumour-free time for the group NC (43 years) was shorter that the longest time of the groups $C$ and $H$ ( 50 resp. 49 years), with these two latter groups the mean is calculated over the period of $0-43$ years. In this way the groups are easier to compare. These means and standard-errors are marked with an " under the tables $12.11,12.12$ and 12.13 .

Tabel 12.11 Mean tumour-free time with the standard-error of the groups C, H and NC

\begin{tabular}{llll}
\hline & $C$ & $H$ & $N C$ \\
\hline mean & $39.23^{*}$ & $38.87^{*}$ & 41.57 \\
s.e. & $.602^{*}$ & $1.083^{*}$ & .657 \\
\hline
\end{tabular}

The difference between the groups $\mathrm{C}$ and $\mathrm{H}$ appeared to be non significant $(\mathrm{p}=0.575 \log$ ranktest), the difference between the groups $C$ and NC was significant $(p=0,011$, logranktest), while the difference between the groups $\mathrm{H}$ and $\mathrm{NC}$ did appear to be significant $(\mathrm{p}=0.019 \log$ ranktest).

Tabel 12.11 indicates the mean tumour-free time with the standard-error when the groups $\mathbb{C}$ and $\mathrm{H}$ are put together and compared to the group NC. The difference appears to be significant $(\mathrm{p}=0.007$ logranktest) .

Tabel 12.12. Mean tumour-free time and standard-error of the groups $\mathrm{C}+\mathbb{H}$ and $\mathrm{NC}$

\begin{tabular}{lrr}
\hline & $\mathrm{C}+\mathrm{H}$ & $\mathrm{NC}$ \\
\hline mean & $38.97^{*}$ & 41.57 \\
s.e. & $.541^{*}$ & .657 \\
\hline
\end{tabular}


Figure 12.1 shows the tumour-free survival curve of the groups $\mathrm{C}, \mathrm{H}$ and $\mathrm{NC}$. This curve shows. at every point of time the percentage of patients that as yet have no carcinoma.

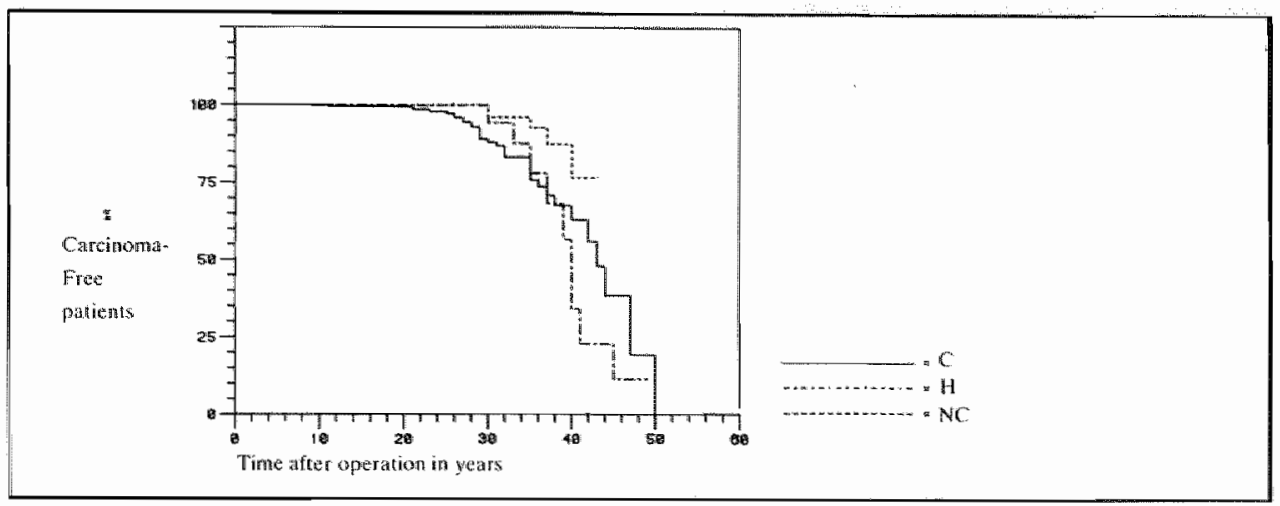

Figure 12.1

Tumour-free survival curves of the groups $\mathrm{C}, \mathrm{NC}$ and $\mathrm{H}$

From this it appears that in the various groups 20 years post-operative, the number of patients with no carcinoma is practically $100 \%$. Thirty years after the primary operation the carcinoma percentage is about $100 \%$ in the group with a haemorrhage and in the group with no complaints, while in the group with complaints this is about $88 \%$.

When a $95 \%$ reliability-interwal is calculated for the 99 th percentile of the NC-group (the point on which $99 \%$ of the group with no symptoms has no carcinoma as yet), this turns out to be the interval $30-40$.

Because in literature it is indicated that the time interval between primary operation to carcinoma diagnosis is longer according as the patient was operated at an earlier age, this was checked with regards to the carcinoma patients involved in our study. The patients were divided into four groups according to the age when primary operated; younger than 27 years of age, 27 up to and including 33 years of age, 34 up to and including 41 years of age and over 42 years of age. The information is given in table 12.13 .

Table 12.13. Age when operated and mean tumour-free time with standard-error

\begin{tabular}{|c|c|c|c|c|}
\hline age in years & $\leq 27$ & $27-34$ & $34-42$ & $\geq 42$ \\
\hline mean & $40.96^{\circ}$ & $39.42^{*}$ & 39.52 & $38.21 \%$ \\
\hline s.e. & $.708^{*}$ & $.772^{*}$ & .872 & $1.529^{*}$ \\
\hline
\end{tabular}

Although there seems to be a slight trend toward the direction of the occurrence of the carcinoma at an earlier point with older patients, the differences, especially between the extreem groups, are not significant ( $p=0.169$ logranktest). From this it can be concluded that the age at the time of the operation is of little influence to the point of time when the carcinoma occurs. It should be expressly remarked with these statistical data, that in view of the small number of carcinomas with respect to the number of patients examined, estimates of tumour-free curves and parameters are in particular inaccurate. Taking this into account, it seems reasonable to start examining patients with no complaints, with a BII-resection stomach from 20 years postoperative.

- Because the phenomenon moderate dysplasia cannot be regarded as a precancerous condition and because no other precancerous lesions have been described so far, the indication of the time-interval when the examination of the resection-stomach should be repeated, can only take place arbitrary. Patients with whom the suspicion of an early stump-carcinoma is pronounced on grounds of a slight abnormality of the mucous membrane on endoscopy, and in which this is not histologicailly confirmed, an endoscopical examination can take place after three to six months. When there is no endoscopical suspicion of an early carcinoma and histological examination of multiple biopsies appears to be negative, then re-examination can take place after a period of between 1 to 2 years. 
Because curative surgical intervention (total or sub-total stomach resection) with older patients with cardiovascular diseases, pulmonall lesions and other organ failure, involves a notably higher operating risk, it should be regarded when selecting patients considered for examination, that patients with notably higher operating risks should be excluded for examination. In relationship with the potential possibility of laser therapy for patients with an early carcinoma of the stomach-stump, it should further be mentioned, that the early-carcinoma may exist multifocally. Consequently, focussing a laserbeam will not be very possible. The question arises if with the potential application of this therapy it will be possible to carry out the frequent endoscopical controlmexaminations, which necessarily must take place, with this group of older patients mentioned. 


\section{Conclusions}

From studying literature as well as the information from the study on subject, the following conclusions can be put forward:

1. Though there may be different pathogenetic mechanisms underlying the development of the carcinoma of the gastric remnant, with regard to the locating of stoma and corpus, there are no differences perceptible of any importance related to average age and interval, pattern of complaints, endoscopical and histological pictures. So there are no practical comsequences to distinguish the carcinoma of the gastric remnant according to localizing.

2. Because of lack of essential information from the period of the operation of the population patients who had a stomach resection in the region of Maastricht in the past, it was not possible to calculate a frequency of occurrence of the stump-carcinoma with these patients. On examining 617 patients with a BI- and BII-resection stomach, more than 10 years post-operative, a stump-carcinoma was more frequently seen with patients after a BII-resection (468 patients. 48 stump-carcinomas $=10.3 \%$ ) than after a BI-resection (149 patients, 2 stump-carcinomas $=1.3 \%)$. The difference is significant $(p<0.01)$.

3. On comparison of endoscopical and histological pictures of non-carcinoma patients with a BIresection stomach, more than 10 years post-operative, distinguished after the existence or non-existence of complaints, there are significantly more ulcerative/erosive lesions diagnosed $(p<0.05)$ endoscopically with the patients with complaints.

Histological there exist no significant differences with regard to the studied phenomenons, that could be related to the patients' complaints. On grounds of information from histological examination the question arises if complaints of these patients can be related to diseases of the stomach such as e.g. gastritis, diagnosed during the examination. On comparison of endoscopical and histological pictures of non-carcinoma patients with a BII-resection stomach, more than 10 years post-operative, distinguished after the existence or non-existence of complaints, there are significantly more ulcerativelerosive lesions endoscopically diagnosed $(\mathrm{p}<0.02)$ with patients with complaints. Histologically there are no significant differences in regard to the studied phenomenons, which could be related to the patients' complaints. On grounds of data from histological examination, the question may arise if complaints from these patients may be related to diseases of the stomach, like e.g. gastritis, diagnosed during the examination.

4. The frequency of occurrence of the stump-carcinoma with patients with a BI-resection stomach with and with no complaints (106 patients with complaints, 2 stump-carcinomas $=$ $1.9 \% ; 43$ patients with no complaints, 0 stump-carcinomas $=0.0 \%$ ) does not differ significantly. The prognosis of the stump carcinoma with symptomatic patients is bad.

The frequency of occurrence of the stump-carcinoma with patients with a Bll-rescction stomach with and with no complaints (118 with complaints, 14 stump-carcinomas $=\| 1.8 \%$; 138 patients with no complaints, 5 stump-carcinomas $=3,6 \%)$ differs significantly $(p<0,02)$. With patients with no symptoms the stump-carcinoma may be detected at an early examination as an early carcinoma, often of multifocal origin; the prognosis with these patients is good. The stump-carcinoma of the symptomatic patients is nearly always diagnosed at a later stage; in general the prognosis is bad.

5. On comparison of endoscopical and histological pictures of three groups of non-carcinoma patients, distinguished after the existence of a BI- and a Bll-stomach (group A: with complaints, from 1970 up to and including 1979; group B: with complaints from 1980 up to and including 1982; group C: no complaints from 1980 up to and including 1982;), more than 10 years post-operative, the following data results:

- mucous membrane of the antrum-character is more frequently seen with the BII-stomach on stoma level than with the BI-stomach on stoma level; with two of the 3 groups examined (groups $A$ and $C$ ) this difference is significant $(\mathrm{p}<0.01)$;

- at stoma level of the BII-stomach the phenomenon cystic dilatation of the glandular tubules is more frequently seen than at stoma level of the BI-stomach; with 2 of the 3 groups examined (groups $B$ and $C$ ) this difference is significant $(p<0.02$ resp. $p<0.01$ ); the phenomenon cystic dilatation of the glandular tubules at stoma level of the BII-stomach 
may count as a characteristic abnormal feature of the stoma of the BII-stomach;

- on endoscopy a large amount of bile is more frequently seen at BUI-stomach level than with the BI-stomach; with the two groups (groups B and C) examined on this the difference is significant $(p<0.01$ resp. $p<0.05)$;

- the stump-carcinoma seems to occur more often at the BII-stomach level than in the BIstomach; the difference is significant $(\mathrm{p}<0.02)$ with one of the three groups (group B).

6. When a haemorrhage occurs with patients with a BII-stomach, more than 20 years postoperative, the possibility of a stump-carcinoma ought to be strongly considered, especially when no potential cause for the haemorrhage is found with the anamnesis. The prognosis of these patients with a carcinoma of the stomach-stump is generally bad.

7. Though no definite opinions with regard to the histological phenomenon moderate dysplasia can be given, on grounds of studie material, the following data appear from this study;

- to diagnose the phenomenon moderate dysplasia, multiple biopsies ought to be taken at stoma level:

- the phenomenon moderate dysplasia occurs almost equally at stoma level with the BI- and the BII-resection stomach;

- the phenomenon moderate dysplasia occurs more often at stoma level with patients with a carcinoma of the stomach-stump than with patients with no carcinoma;

- on a control-examination of patients with moderate dysplasia at stoma level, a moderate dysplasia is diagnosed again with only half the number of patients, although multiple biopies wera taken;

- the phenomenon moderate dysplasia at stoma level cannot simply be considered as a precancerous condition.

8. Considering very critically the conditions for an acceptable screening of patients with a resection stomach with no complaints, it seems that requirements camnot be met simply.

9. It seems to be possible to select patients, from the population of patients with a BI- and a BIIresection stomach, who are considered for endoscopical and histological examination for an early diagnosis of a stump-carcinoma still at a curative stage. These patients can be characterized as follows: patients with a BII-resection stomach, from 20 years post-operative, with no diseases through which a greater operating risk exists. 


\section{Literatuurlijst}

Albert H, Nowotny K. Das primäre Stumplkarzinom und seine klinische Bedeutung; Zentralb] Chir 3: 78; 1970.

Bähr R, Röhrle-Lehmann S, Geisbe H. Statistische Untersuchungen zur Atiologie des Magenstumpfkarzinoms; Med Welt 31: 123; 1980.

Beatson GT. Carcinoma of the stomach after gastro-jejunostomy; $\mathbb{B r}$ Med J 1: 15; 1926.

Berkowitz D, Cooney R, Bralow SP. Carcinoma of the stomach appearing after previous gastric surgery for benign ulcer disease; Gastroenterology 36: 691; 1959.

Billroth CAT. Offenes Schreiben an Herrn Dr L Wittelshöfer; Wien Med Wochenschr 31: 1427; 1881.

Boeckl O, Lill H. Ueber das Magenstumpfkarzinom; Münch Med Wochenschr 105: 615; 1963.

Boer J de, Huibregtse K. Tytgat GNJ. Gastric carcinoma after partial gastrectomy; Tijdschr Gastroent 3: 158;1978.

Borg I. Bille admixture in gastric juice in health and in peptic ulcer before and after operation according to Billroth II and Billroth I; Acta Chir Scand (suppl) 251: 97; 1959.

Bosseckert H, Kreibich U. Magenstumptkarzinom bei Routinegastroskopien; Dtsch Z Verdauu Stoffwechselkr 40: $63 ; 1980$.

Böttcher $\mathbb{H}$, Hantschmann N. Das Magenstumpfkarzinom; Med Klin 68: 175; 1973.

Braun $\mathrm{H}$. Uber Gastro-enterostomie und gleichzeitig ausgeführte Entero-anastomose; Arch Klin Chir 45: 361; 1893.

Brünner $\mathrm{H}$, Krieg H, Daniels V. Ergebnisse nach Gastrektomie mit Passage wiederherstellung nach Longmire; Med Welt 33: 237; 1982.

Busman DC. Results of highly selective vagotomy; Academisch Proefschrift RL Maastricht; Schrijen-Lippertz, Voerendaal 1983.

Clemençon $G$, Baumgartner R, Leuthold E, Miller G, Neiger A. Das Karzinom des operierten Magen; Dtsch Med Wochenschr 101: 1015; 1976.

Dahm K, Eichen R, Mitschke H. Das Krebsrisiko im Resektionsmagen; Langenbecks Arch Chir $344: 71 ; 1977$.

Dahm K, Eichfuss HP, Koch W. Cancer of the gastric stump after Billroth II resection; Front Gastrointest Res 5: 164; 1979.

Dahm K, Rehner M. Das Karzinom im operierten Magen. Stuttgart, Thieme 1975.

Dahm K, Werner B. Experimentelles Anastomosencarcinom. Ein beitrag zur Pathogenese des Magenstumpfcarcinom; Langenbecks Arch Chir 333: 21.1; 1973.

Denk H, Salzer G. 21 Jahre Ulkuschirurgie an der Klinik Denk in Wien 1933-1954; Gastroenterologie 88: $94 ; 1957$.

Dick W, Rösch W. Rezidivulkus und Karzinom im operierten Magen; Med Welt 32: 611.; 1981.

Dirschmid K, Vogel W, Troyer E. Magenstumpfpolypen; Leber Magen Darm 11: $136 ; 1981$.

Domellö $L$, Eriksson $S$, Janunger $K G$. Precancerous changes and carcinoma of the gastric stump after resection for benign ulcer disease; Chir Gastroent 10: 263; 1976.

Domellö L, Eriksson S, Janunger KG. Late precancerous changes and carcinoma of the gastric stump after Billroth II resection; Am J Surg 132: 26; 1976.

Domellöf L, Eriksson S, Janunger KG. Carcinoma and possible precancerous changes of the gastric stump after Billroth UI resection; Gastroenterology $73: 462 ; 1977$.

Domellöf $\mathrm{L}$, Janunger $\mathrm{KG}$. The risk for gastric carcinoma after partial gastrectomy; Am J Surg $134: 581 ; 1977$.

Domellöf L, Reddy BS, Weisburger $I H$. Microflora and deconjugation of bille acids in alkaline reflux after partial gastrectomy; Am J Surg 140: 291; 1980.

Dony A, Witte Cl de, Serste JP, Deschreyer M. Le cancer du moignon gastrique après gastrectomie pour ulcère * Acta Gastroenterol Belg 36: 544; 1973.

Dougherty SH. Foster CA, Eisenberg MM. Stomach cancer following gastric surgery for benign disease; Arch Surg 117: 294; 1982.

Dragstedt $\mathbb{L} R$, Owens FM. Supradiaphragmatic section of vagus nerves in the treatment of duodenal ulcer; Proc Soc Exp Biol 53: 152; 1943.

Dragoni G. Il carcinoma del moncone gastrico; Minerva Med 54: 462; 1963 .

Eberlein TJ, Lorenzo FV, Webster MW. Gastric carcinoma following operation for peptic ullcer disease; Ann Surg 187: 251; 1978.

Eichelter $G$. Spontanperforation des paralytisch erweiterten Duodenalschenkels 4 Jahre nach subtotaler Magenresektion wegen Ulcus; Deutsche. Ztschr Chir 222: 106; 1930. 
Es J van. Patient en huisarts; Utrecht, Bohn Scheltema \& Holkema 1980.

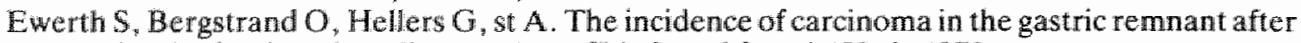
resection for benign ulces disease; Acta Chir Scand Suppl 482:2; 1978 .

Finsterer $H$. Ausgedehnte Magenresektion bei Ulcus duodeni statt der einfachen Duodenalresektion bzw Pylorusausschaltung; Zbl Chir 45: 434; 1918.

Frankson C. Selective abdominal vagotomy; Acta Chir Scand 96: 409; 1948.

Franzin $G$, Novelli P. Gastritis cystica profunda; Histopathology 5: 535; 1981.

Freedman MA, Berne CJ. Gastric carcinoma of gastrojejunal stoma; Gastroenterology 27: 210; 1954.

Fuifta S. Biology of early gastric carcinoma; Pathology Research and Practice 163; 297: 1978.

Geboes $K$, Rutgeers $P$, Broeckaert L, Vantrappen $G$, Desmet $V$. Histologic appearances of endoscopic gastric mucosal biopsies 10-20 years after partial gastrectomy; Ann Surg 192: 179; 1980.

Geile D, Ultsch B. Endoscopic examination of the operated stomach; Endoscopy 9: 115; 1977.

Gerstenberg E, Albrecht A, Krentz K, Voth H. Das Magenstumpfkarzinom: eine Spätkomplikation des operierten Magen?; Dtsch Med Wochenschr 90: 2195; 1965.

Giacosa A. Molinari F, Perasso A, Cheli R. Endoscopic experience in the diagnosis of gastric stump cancer; Front Gastrointest Res 5: 160; 1979.

Griesser $G$, Schmidt H. Statistische Erhebungen über die Häufigkeit des Karzinoms nach Magenoperation wegen eines Geschwürleidens; Med Welt 35: 1.836; 1964.

Grosse H. Das Magenstumptkarzinom im Sektionsgut; Dtsch Z Verdau -u Stoffwechselkr 38: $137 ; 1978$.

Grundmann E. Histologie und Histogenese des Magen-Frühcarcinoms; Therapiewoche 24: $3824 ; 1974$.

Grüngreiff K, Kleine FD, Höts T, Kleine S. Magenoperierte Patienten - Eine retrospektive Betrachtung; Z Ges Inn Med 33: 433; 1978.

Hacker von V. Zur Kasuristik der Magenresektion und Gastro-enterostomien; Arch Klin Chir $32: 616 ; 1885$.

Haemers S, Hoste P, Elewaut A, Alderweireldt W, Mortier G, van Maele V, Barbier F. Het maagstompcarcinoom; Ned Tijdschr Geneesk 124: 636; 1980.

Hammar $E$. The localization of precancerous changes and carcinoma after previous gastric operation for benign condition; Acta Path Microbiol Scand 84: 495; 1976.

Harkins HN, Jesseph JE, Stevenson JK, Nyhus LM. The combined operation for peptic ulcer; Arch Surg 80: 743; 1960.

Hebold G. Das Karzinom im Restmagen; Med Klinik 53: 1813; 1958.

Heinzel J, Laqué H. Magenkarzinome nach frühere Resktion wegen Ulkus Ventriculi bzw Duodeni, Langenbecks Arch Chir 278: 87; 1954.

Helsingen $\mathbb{N}$, Hillestad $L$. Cancer development in the gastric stump after partial gastrectomy for ulcer; Ann Surg 143: 173; 1956.

Hermanek P. Riemann JF. The operated stomach - still a precancerous condition? Endoscopy 14: 113; 1982.

Hilbe G, Salzer GM, Huss $H$, Kutchera H. Die Carcinomgefahrdung des Resektionsmagens; Langenbecks Arch Klin Chir 323: 142; 1968.

Holle F, Hart W. Form- und Funktionsgerechte Operation. Ein Grundsatz moderner Ulkuschirurgie; Arch Klin Chir 309: 205; 1965.

Hünicke H, Schröder H, Peter U. Bericht über 20 Magenstumpfkarzinome; Zbl Chir 105: 167; 1980.

Jablokow VR, Aranha GV, Reyes CV. Gastric stomal polypoid hyperplasia: Report of four cases; I Surg Oncol 19: 106; 1982.

Iackson RG. Anatomic study of the vagus nerves with a technic of transabdominal selective gastric vagus resection. Arch Surg 57: 333; 1948.

Janunger $\mathrm{KG}$, Domellöf $\mathbb{L}$. Gastric polyps and precancerous mucosal changes after parial gastrectomy. Acta Chir Scand 144: 293; 1978.

Kaiser C, Zanoni G, Eglin RE. Klinische Spätkontrolle 11-20 Jahre nach Magenresektion Billroth I wegen Gastroduodenalulzera; Helv Chir Acta 41: 125; 1974.

Kawai K, Miyaoka T, Kohli U. Evaluation of early gastric cancer from the clinical point of view. In: Grundmann E, Grunze H, Witte S. Early gastric cancer; Berlin: Springer; 1974.

Kidokoro T, Serata S, Hayashida Y, Urabe M, Yamashita K, Watanabe S, Maekawa K. Magenfrühkarzinom in Japan - Ergebnisse. In; Beger H, Bergemann W, Oshima H. Das Magenkarzinom; Stuttgart: Thieme; 1980. 
Kivilaakso E, Hakkiluoto A, Kalima TV, Sipponen P. Relative risk of stump cancer following partial gastrectomy. Br J Surg 64: 336; 1977.

Klarfeld J, Resnick G. Gastric remnant carcinoma; Cancer 44: 1129; 1979.

Kobayashi S, Prolla JC, Kirsner JB. Late gastric carcinoma developping after surgery for benign conditions. Digestive Diseases 15: 905; 1970.

Konjetzny GE. Der Magenkrebs; Stuttgart: Enke Verlag; 1938.

Kootz F. Das Magenstumpfkarzinom nach Operation eines benignen Magenleidens; Bruns Beitr Klin Chir 215: $275 ; 1967$.

Kratochvil P, Brandstätter G. Endoskopie des BII-resezierten Magens; Wiener Med Wochenschr 16: 508; 1977.

Krause U. Late prognosis after partial gastrectomy for ulcus. A follow-up study of 361 patients operated upon from 1905 to 1933. Acta Chir Scand 114: 341; 1957.

Krentz K. Integrated atlas of gastric diseases; Stuttgart: Thieme; 1976.

Kronberger $\mathbb{L}$, Haffner $H$. Uber das primäre Stumpfkarzinom nach Ulkusresektion Chirurg 39 : $118 ; 1968$.

Kühlmayer R, Rokitansky O. Das Magenstumpfkarzinom als Spätproblem der Ulkuschirurgie; Langenbecks Arch Klin Chir 278: 361; 1954.

Langhans P, Heger RA, Hohenstein J. Das Krebsrisiko des operierten Magens. Z Allg Med 56: $1360 ; 1980$.

Langhans P, Heger RA, Hohenstein J, Schlake W, Bünte H. Operationsequel carcinoma of the stomach. Experimental studies of surgical techniques with or without resection. World J Surg $5: 595 ; 1981$.

Lauren P. The two histological maintypes of gastric carcinoma: Diffuse and so-called intestinal type carcinoma. Acta Path Microbiol Scand 64: 31; 1965.

Liavaag K. Cancer development in gastric stump after partial gastrectomy for peptic ulcer. Ann Surg 155: 103; 1962.

Lüders $\mathbb{K}$, Radomsky J, Ungeheuer $\mathbb{E}$. Magenstumpfkarzinom. Med Klin 74: 91; 1979.

Marquardt H, Rufino F, Weisburger JH. On the aetiology of gastric cancer: Mutagenicity of four extracts after incubation with nitrite; Fd Cosmet Toxicol 15: 97; 1977.

Mason MK. Surface carcinoma of the stomach. Gut 6: 185; 1965.

Mitschke H. Pathologisch-anatomische Grundlagen der Krebsrisikoerkrankungen und des Frühcarcinoms des Magens. Chirurg 49: 465; 1978.

Morgenstern L, Yamakawa T, Seltzer D. Carcinoma of the gastric stump. Am J Surg 125: 29; 1973.

Mörl H. Spättodesursachen bei Magenresezierten nach Billroth II. Med Klinik 62: 1904; 1967.

Morson BC, Sobin LH, Grundmann E, Johansen A, Nagayo T, Serck-Hansen A. Precancerous conditions and epithelial dysplasia in the stomach. J Clin Pathol 33: 711; 1980.

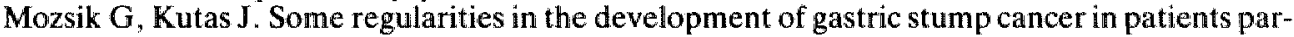
tially gastrectomized for duodenal ulcus. Acta Med Acad Scient Hung 37: 67; 1980.

Nagayo T. Histological diagnosis of biopsied gastric mucosa with special reference to that of borderline lesions. Gann Monogr Cancer Res 11: 245; 1971.

Nagayo T, Yokoyama $\mathrm{H}$. Cancer of the gastrointestinal tract. Early plaases and diagnostic features. JAMA 228: 888; 1974.

Nicholls JC. Carcinoma of the stomach following partial gastrectomy for benign gastroduodenal lesion. Brit J Surg 61: 224; 1974.

Nicholls JC. Stump cancer following gastric surgery. World J Surg $3: 731 ; 1979$.

Oehlert W, Keller P, Henke M, Strauch M. Die Dysplasien der Magenschleimhaut. Dtsch Med Wochenschr 100: 1950; 1975.

Offerhaus GJA, Stadt van de J, Huibregtse K, Olffen van GH, Tytgat GNJ. De betekenis van dysplasie bij onderzoek naar een maligne proces. Ned Tijdschr Geneesk 126:2320; 1982.

Orlando R, Welch JP. Carcinoma of the stomach after gastric operation. Am J Surg 141: 487; 1981.

Oscarson JEA. 27 Kongr Int Ges Chir 1978; Ref Med Klinik 73: 625; 1978.

Osnes M, Lotveit T, Myren J, Serck-Hanssen A. Early gastric carcinoma in patients with a Billroth II partial gastrectomy. Endoscopy 9: 45; 1977.

Owen DR. Carcinoma after gastroenterostomy. Brit Med J 1: 825; 1926.

Peitsch W, Becker HD. Frequency and prognosis of gastric stump cancer. Front Gastro-int Res 5: $170 ; 1979$.

Peitsch W, Becker HD. Was ist gesichert in der Pathogenese und Häufigkeit des primären Carcinoms im operierten Magen? Chirurg 50: 33; 1979. 
Peitsch W, Burkhardi K. Zur Pathogenese und Klinik des Magenstumpfcarcinoms; Langenbecks Arch Chir 341: 195; 1976.

Peters H, Schubert HJ, Reifferscheid M. Das Karzinom im Restmagen nach Resektion wegen gutartigen Befunde. Langenbecks Arch Chir 336: 219; 1974.

Prinz H. Uber Krebsbildungen im Gastroenterostomierung und deren Bedeutung für die Lehre won der Krebsentstehung im Magen. Langenbecks Arch Chir 191: 140; 1938.

Proot $L$, Derom F. Sequelen na maagchirurgie voor een ulcus-diathese. Tijdschr Gastroent 5 : $355 ; 1978$.

Radornsky J, Lüders K, Ungeheuer E. Chirurgische Behandlung des Magenstumpfkarzinoms. Münch Med Wochenschr 120: 557; 1978.

Rauwerda JA. Het malagstompcarcinoom. Acad Proefschrift VU Amsterdam. Swado Grafigroep BV Amsterdam, 1979.

Rauwerda JA. Het maagstompcarcinoom. Ned Tijdschr Geneesk 124: 632; 1980.

Rehner M, Soehendra N, Werner B. Klinik und Diagnostik. In: Dahm K, Rehner M. Das Karzinom im operierten Magen. Suttgart: Thieme Verlag; 1975.

Reissigl H, Schwamberger K. Endoskopie beim operierten Magen. Akt Gastrologie 5: 169; 1976.

Reissigl H, Schwamberger K. Billroth II retrokolisch. Z Allg Med 57: 673; 1981.

Rösch W, Elster K. Gastrointestinale Präkanzerosen. Baden-Baden Brussel: Witzstrock; 1977.

Rösch W. Endoskopische Diagnostik und Therapie bei Krebsrisikoerkrankungen und beim Frühcarcinom des Magens. Chirurg 49:473; 1978.

Rydygier L. Die erste Magenresektion bei Magengeschwür. Zbl Chir 9: 198; 1882.

Saegesser F, James D. Cancer of the gastric stump after partial gastrectomy (Billroth II principle) for ulcer. Cancer 29: 1150; 1972.

Savage A, Jones S. Histological appearances of the gastric mucosa 15-27 years after partial gastrectomy. J Clin Path 32: 179; 1979.

Schade ROK. The borderline between benign and malignant lesions in the stomach. In: Grundmann E, Grunze H, Witte S. Early gastric cancer; Berlin Heidelberg New York: Springer Verlag; 1974.

Schlag P. Nachsorge nach Operation eines Magenkarzinoms. Ztsch Allg Med 54; 129; 1978.

Schlag $\mathrm{P}$, Ulrich $\mathrm{H}$, Merkle $\mathrm{P}$, Böckler R, Peter M, Herfarth $\mathrm{C}$. Are nitrite and $\mathrm{N}$-nitroso compounds in gastric juice risk factors for carcinoma in the operated stomach. Lancet $1: 727 ; 1980$.

Schlag $P$, Wonka W, Meyer $H$, Feyerabend $G$, Merkle P. Bakterielle Besiedlung und Nitritbildung im Magen nach gastroenteromie. Langenbecks Arch Chir 344: 109; 1977.

Schmid E. Carcinoma of the gastric stump. Tijdschr Gastroenterol 20: $285 ; 1977$.

Schmid E, Vollmer R, Adlung J. Blaich E, Goebell H, Heinkel K, Kimmig JM, Probst M. Zur endoskopischen Diagnostik des Karzinoms im operierten Magen. Ztschr Grastroent 14: 521 ; 1976.

Schnitzier J. Uber Magenchirurgie. Erfahrungen und Betrachtungen. Med Klinik 17: 713; 1914.

Schönleben K, Langhans P. Schlake W, Kautz G, Bünte H. Gastric stump carcinoma. Carcinogenic factors and possible preventive measures. Acta Hepato-Gastroenterol 26: 239; 1979.

Schrumpf E, Stadaas J, Myren J, Serck-Hanssen A. Aune S, Osnes M. Mucosal changes in the gastric stump 20-25 years after partial gastrectomy. Lancet II: $467 ; 1977$.

Schumpelick V. Postoperative alkalische Refluxgastritis. In: Refluxkrankheit des Magens; Stuttgart: Enke; 1979 .

Schumpelick V, Begemann F, Peterhof G, Flasshoff D. Reflux und Refluxkrankheit im Resektionsmagen. Langenbecks Arch Chir 348: 61; 1979.

Schwamberger K, Reissigl H, Troyer E. Das Magenstumptkarzinom. Ztschr Allg Med 55: 439; 1979.

Schwarz H. Berichte aus chirurgische Gesellschaften. Zentrallbl 532: 3000; 1926.

Shafik A. New technique of gastro-jejunal anastomosis after partial gastrectomy. Am J Surg 142: $398 ; 1981$.

Stalsberg $H$, Takstal $\mathrm{S}$. Stomach cancer following gastric surgery for benign conditions. Lancet 27: $1175 ; 1971$.

Stalsberg H, Taksdal S. Stomach cancer following gastric surgery for benign conditions. Cancer 31: $162 ; 1973$

Stemmermann GN, Hayashi T. Hyperplastic polyps of the gastric mucosa adjacent to gastroenterostomy stomas. Am J Clin Pathol 71: 341; 1979.

Stokkeland M, Schrumpf E, Serck-Hanssen A, Myren J, Osnes M, Stadaas J. Incidence of malignancies of the Billroth II operated stomach. Scand J Gastroent (Suppl) 67: 169; 1981. 
Taksdal S, Stalsberg H. Histology of gastric carcinoma occurring after gastric surgery for benign conditions. Cancer 32: 162;1973.

Tautenhahn P, Richter J, Wittig KH. Das Karzinom in voroperierten magen. Z rtzl Fortbild 73: $228 ; 1979$.

Terjesen T, Erichsen HG. Carcinoma of the gastric stump after operation for benign gastro-duodenal ulcer. Acta Chir Scand 142: 256; 1976.

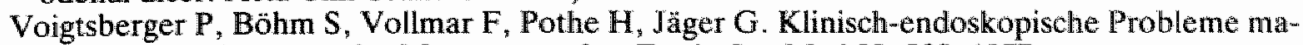
ligner Veränderungen des Magenstumpfes. Ztschr Inn Med 32: 200; 1977.

Weinberg JA, Stempien SJ, Movius HJ, Dagradi AE. Vagotomy and pyloroplasty in the treatment of duodenal ulcer. Amer J Surg 92: 202; 1956.

Welvaart K, Warnsinck HM. Hoe vaak komt magstompcarcinoom voor? Ned Tijdschr Geneesk 126: 2374; 1982 .

Werner B, Leppin A, Seiler I, Mitschke H, Soehendra $\mathbb{N}$, Farthmann E, Rehner M, Dahm K. Duodenaler Reflux und Gastritis im Billroth-1-Magen. Dtsch Med Wochenschr 100: 2385; 1975.

Whitehead R. Mucosal biopsy of the gastrointestinal tract. Londen Saunders; 1973.

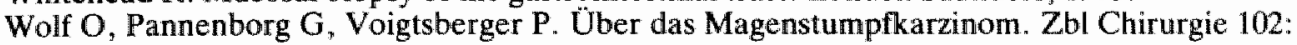
$1183 ; 1977$.

Wölfler A. Gastroenterostomie. Zbl Chirurgie 8: 705; 1881. 


\section{Dankwoord}

Allen die hebben bijgedragen aan het tot stand komen wan dit proefschrift, ben ik bijzonder dankbaar.

Prof. Co Greep, dic zich bereid verklaarde dit proefschrift te begeleiden, hetgeen op de hem aigen, voortvarende wijze is gebeurd. Vanuit hecht gebouwde stellingen is deze these toegevoegd aan zijn zillveren vloot. De internist heeft van de chirurg geleerd!

Prof. Victor Swaen, die microscopisch nauwkeurig het proefschrift van kritische kanttekeningen heeft voorzien.

Prof. Guus Flendrig, die door een scherpziende internistische bril het proefschrift tot een bekeken zaak gemaakt heeft.

Prof. A.J.Ch. Haex, die het manuscript zorgvuldig bestudeerde en zijn nihill obstat verleende, als was het een Leidenswerhaal.

Prof. Ferd Sturmans, die op zijn specifieke wijze het werk screende op gevoelige punten. Van zijn adviezen heb ik frequent gebruik gemaakt.

Jan-Willem Arends, die in een coup honderdtallen preparaten in de maag gesplitst kreeg ter (her)beoordeling, hetgeen woor hem niet onverteerbaar bleek. Het proef-schrift zou zonder zijn kritisch oog de keuken niet verlaten hebben.

Lex Volovich, die de computer tot vervoering bracht. De resultaten spreken voor zich.

Chris Voskamp, die op hem tekenende wijze een wetenschappelijk werk van voor het oog aantrekkelijke kanten weet te voorzien.

Dick Bezem, die in velerlei opzicht coördinerend en de puntjes op de i zettend, het drukker gehad heeft dan menigeen. Met Astrid de Boer verzorgde hij de lay-out en produktie.

Tiny Wouters-Lenssen, die met de hand, typemachime, tekstverwerker en een altijd goed humeur's morgens om 6 uur en "s avonds laat duistere plannen omzette in een heldere tekst. Zij heeft veel vraagtekens tot verdwijnen gebracht.

Marja de Greeve-Dietvorst, Lucie Jongen-Huls en Margo Neven-Penninger, die assisteerden bij de gastroscopie, endoscopische verslagen af- en aansleepten, histologische preparaten te voorschijn toverden uit stoffige archieven en vele endoscopische dia's de revue lieten passeren.

De firma Smith Kline \& French B.V., die het verschijnen van dit proefschrift financieel ondersteunde.

Joan, Luc, Natalie, Ariane, Sabine en Gigi, die mij na de afronding van het proefschrift zullen blijwen stimuleren, ditmaal in het kader van een resocialisatie proces. 


\section{Curriculum vitae:}

08-05-1938 Geboren te Maastricht.

1950 - 1956 Gymnasium bèta - van Veldeke College te Maastricht.

1956 - 1963 Studie geneeskunde aan de Rijkskuniversiteit te Groningen.

1963 - 1965 Militaire Dienst.

1965 - 1969 Opleiding tot internist in het Ziekenhuis St. Annadal te Maastricht (Hoofd van de Opleiding: J.M. Coenegracht).

1969 - 1970 Stage gastroenterologie in het Wilhelmina Gasthuis te Amsterdam (Hoofd van de Afdelling: Dr. A.H. Wiebenga).

vanaf 1970 Werkzaam in Ziekenhuis St. Annadal als algemeen internist met belangstelling gastroenterologie; eveneens verbonden aan de afdeling Haemodialyse (tot 1975) en de afdeling Intensive Care (tot 1981); vanaf 1978 tevens coördinator van het Diagnostisch Centrum. 


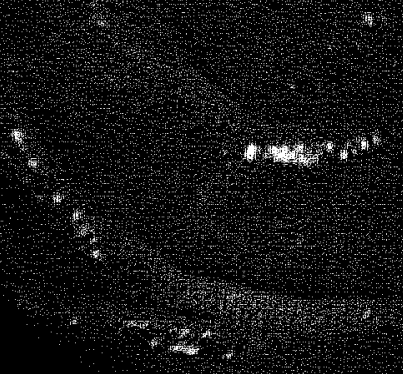

1. Normatal duodenumslijmvlies (Bl-magg).

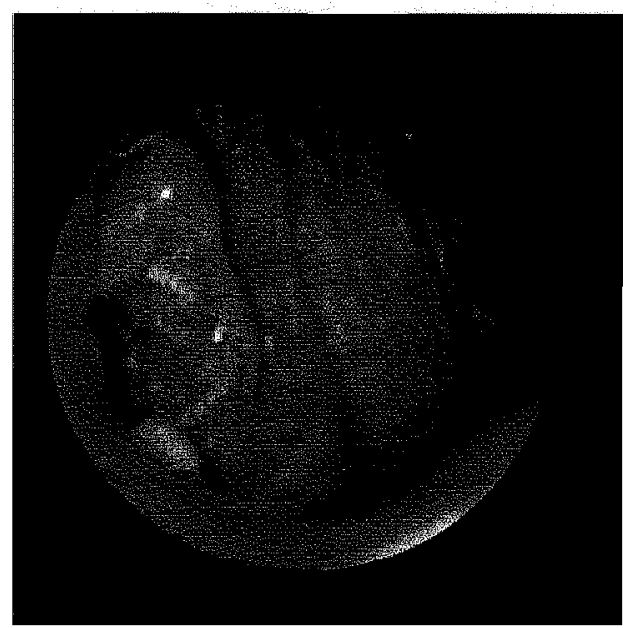

3. Via stoma Bill-mage dicht op jejunumslijmylies en toregung hoi afvoerende lifs.

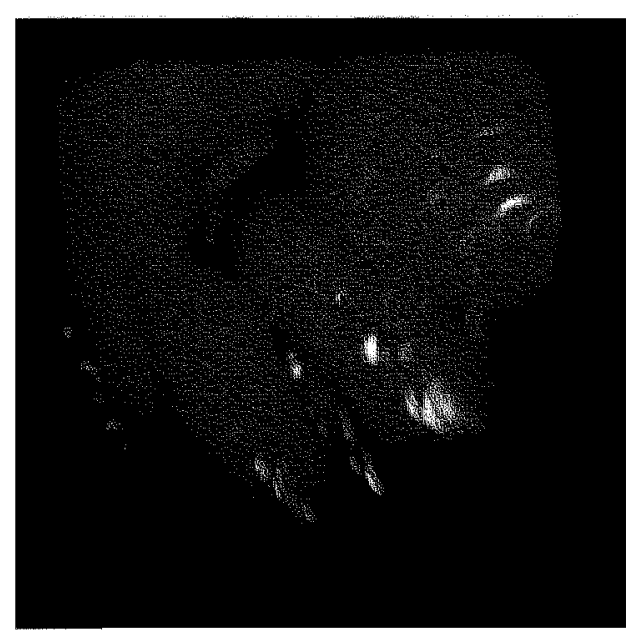

5. Nauw stoma BHl-magh.
2. Jejurum: brug tussen aan-en afwoerende lis (BHmaag).

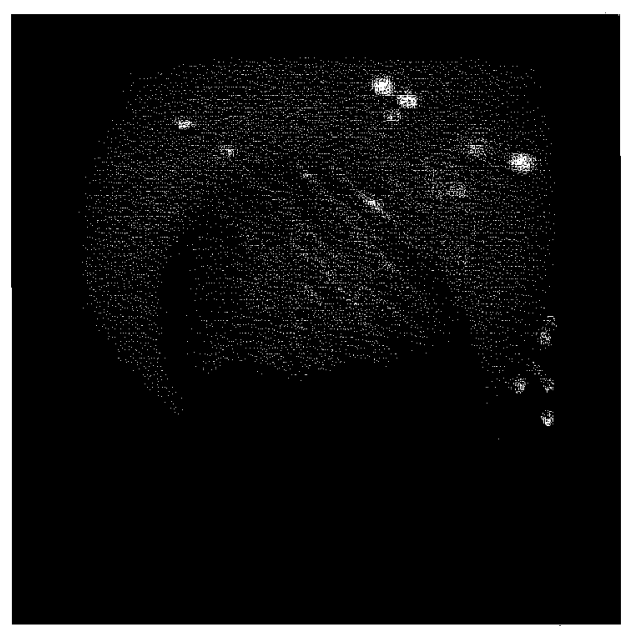

4. Vlak stoma BII-mang met tekenen matige stomagastritis.

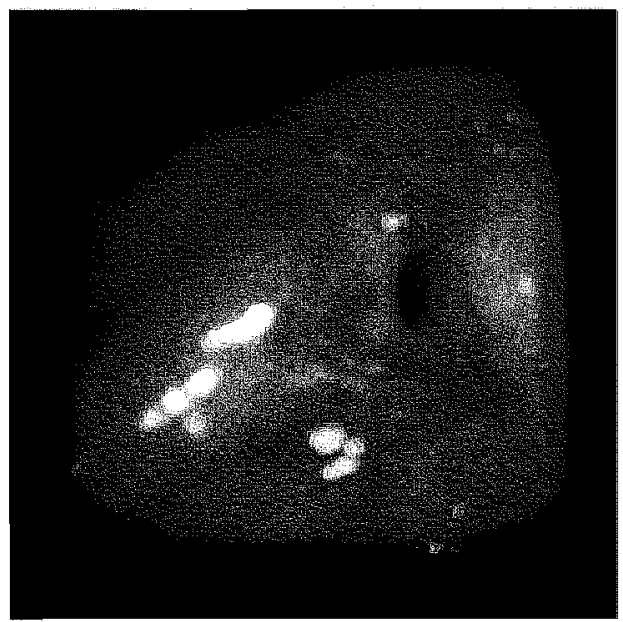

6. Vernauwd stoma BIL-maag met duidelijk geinjiceerden sanguinolent slijmvlies. 


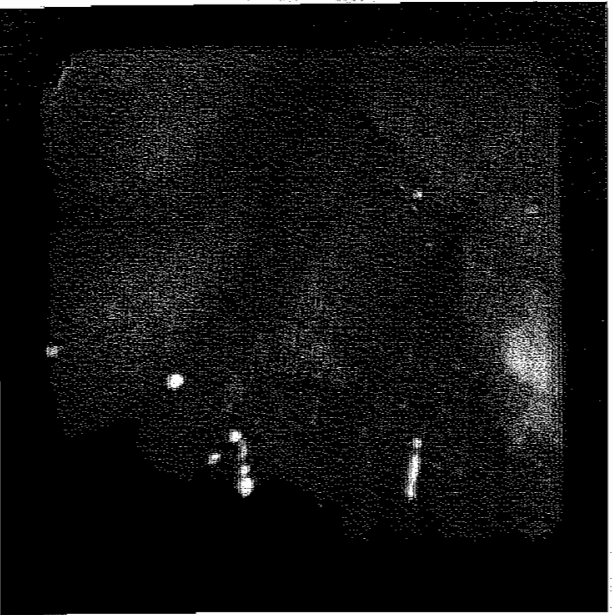

7. Matig geinjiceerde, licht sanguinolente plooien bij stona BII-maag.

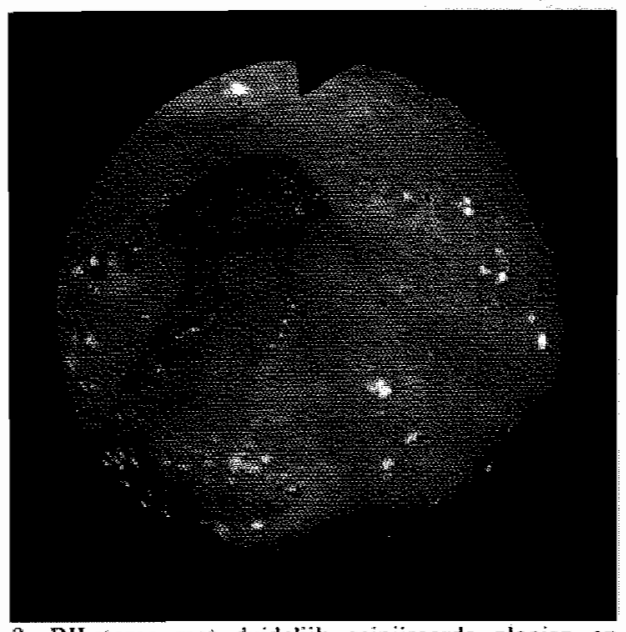

9. BII stoma met duidelijk geinjiceerde plooien en geringe hoeverelheid gall.

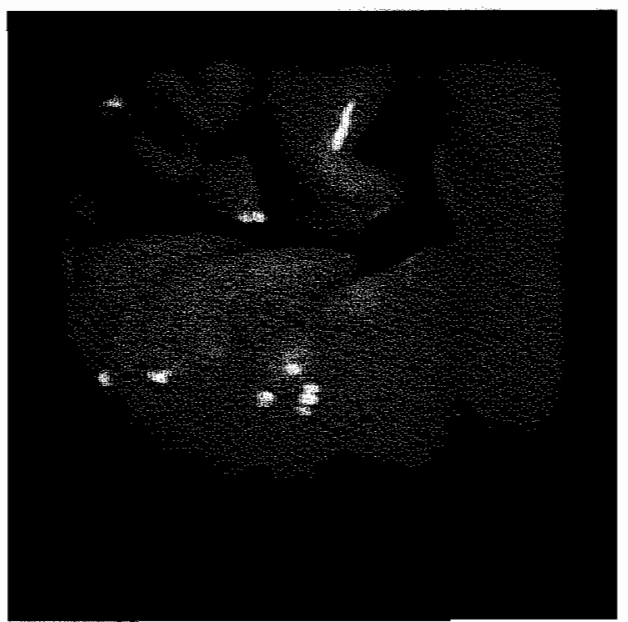

11. Jejunumslijmwhes overgrijpend op stomarand BIImaag.

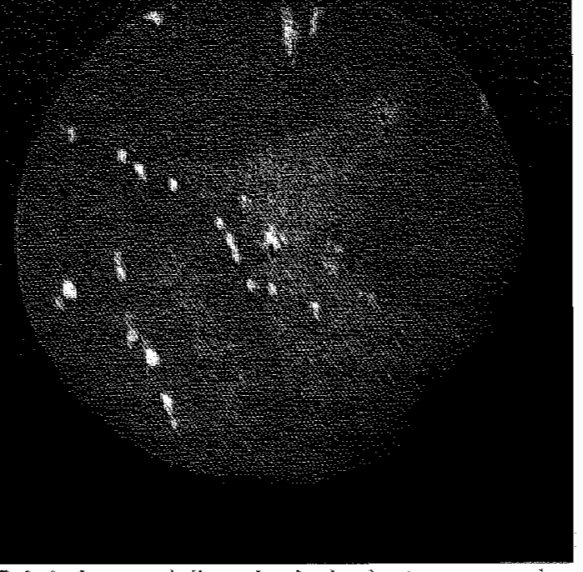

8. Enkele forse, geinjiceerde plooven in stoma tomgeving BII-maag, met gerimge hoveelheid gal.

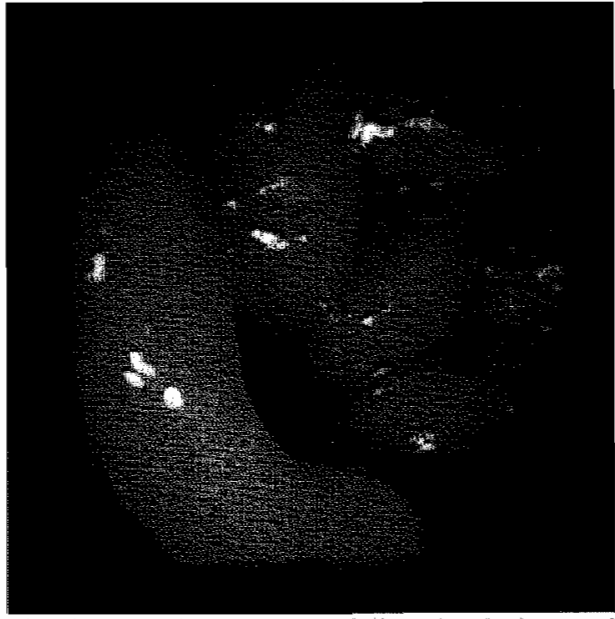

10. Matige oedemateus en geinjiceerde plooien tond stoma Blímag.

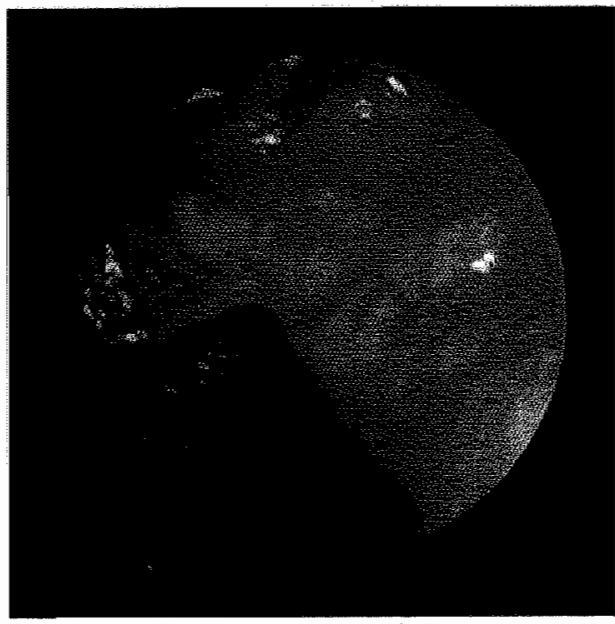

12. Jejunumslijmwlies ap stomarand BII-magh. 


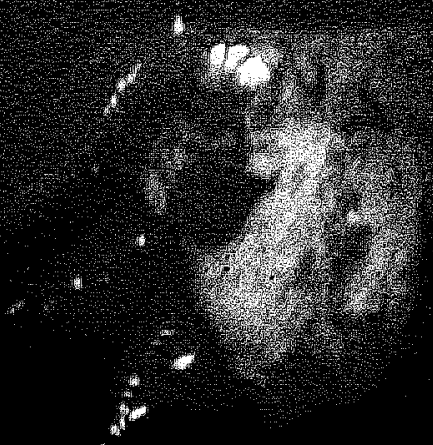

13. Gallig beslag lichi geinjiceerde jejunumplooien Bllmatag.

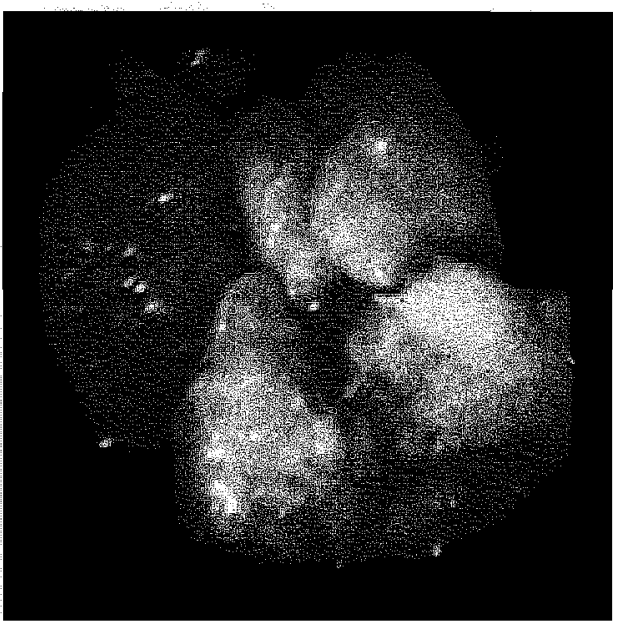

15. Met gal geimpregneerde voedsellesten Brl-mang.

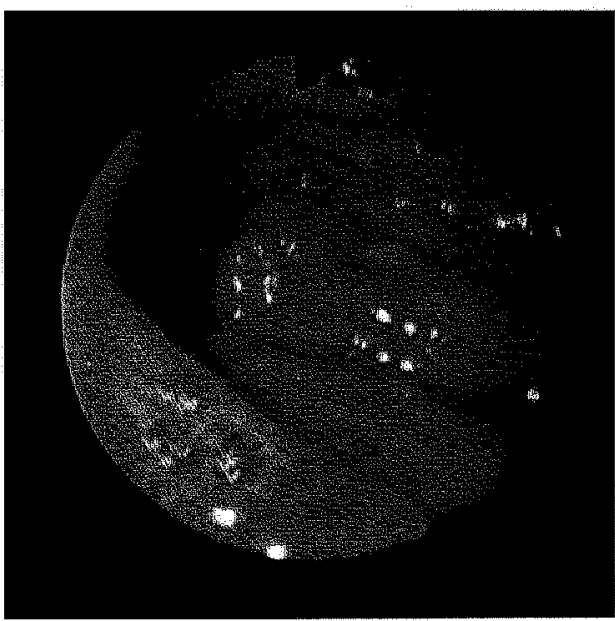

17. Xantelasmatta in praestoma-regio BTHmasy

18. Winttige plekken rond stoma Bll-mang (PA: intestimale metaplasie)

16. Xantelasma op geinjiceerde plooi in praestomaregio Bll-matag.



14. Duidelijk geinjjiceerd corpusslijmvlies BIT-maag, met gallig retentiemateriaal

th

1)

(1)
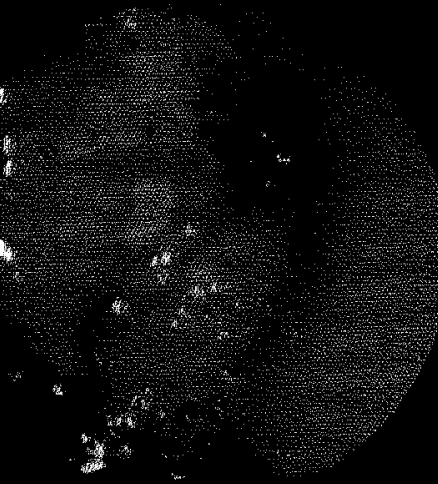


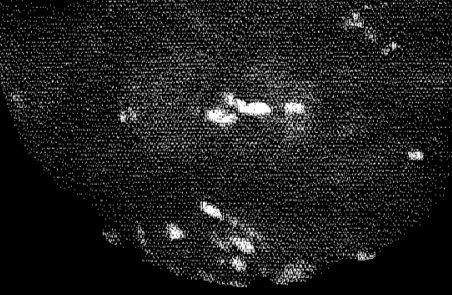

19. Wintige plekken grote curvatuurzijde stoma BlI-maag (PA: intestionale metaplasie met matige atypie).

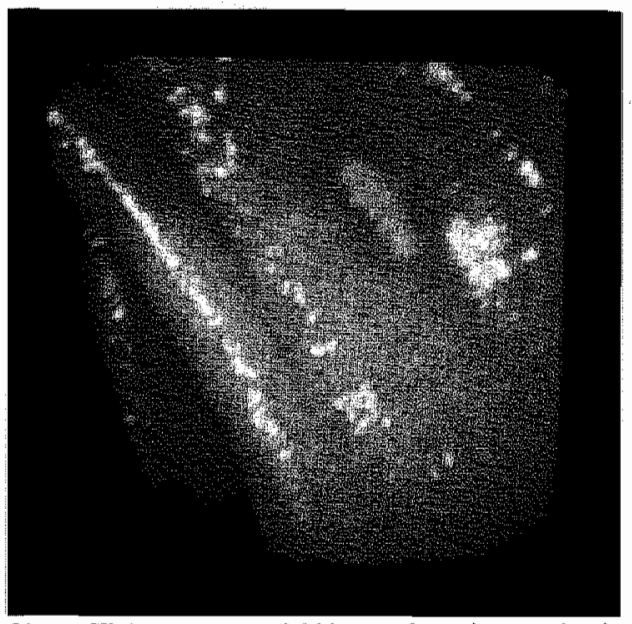

21. Kleine opperwlakkig ulceratieve lagesie jejunumblijmwlies Bli-natag.

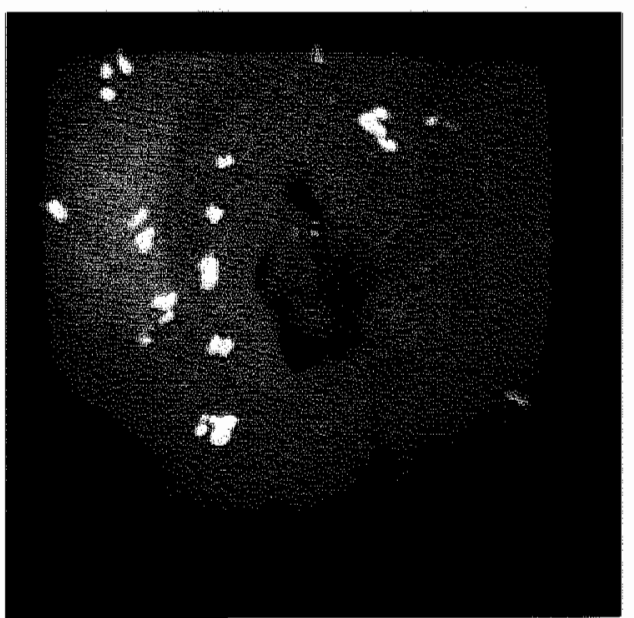

23. Ovaalvormig ulcus voorwandzijde stoma BIl-maag (PA: benigne ulcusi).

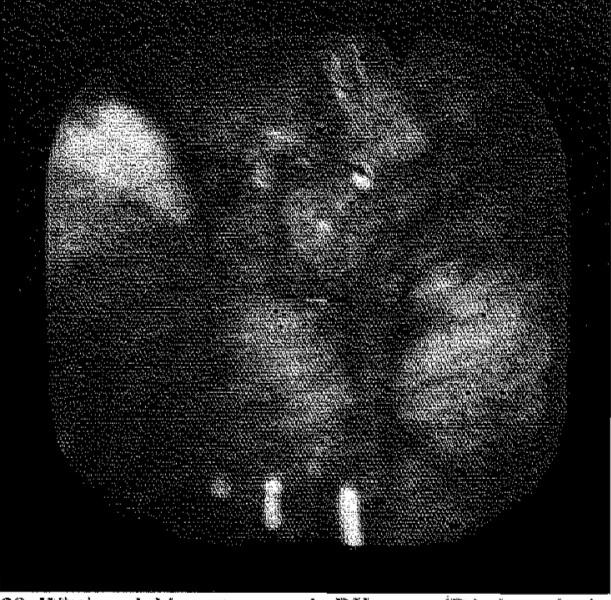

20. Wittige plekken stornaregio BII-maga (PA: inntestinale netaplasie)

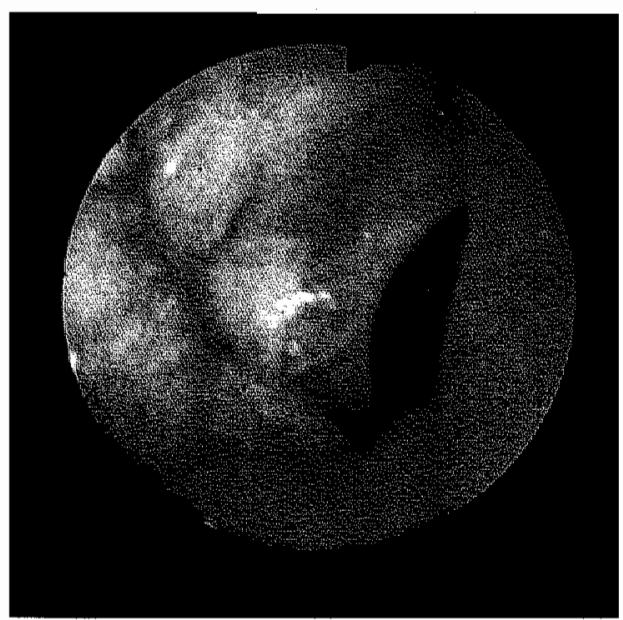

22. Ulcusputje jejunumzijde stoma BII-maag.

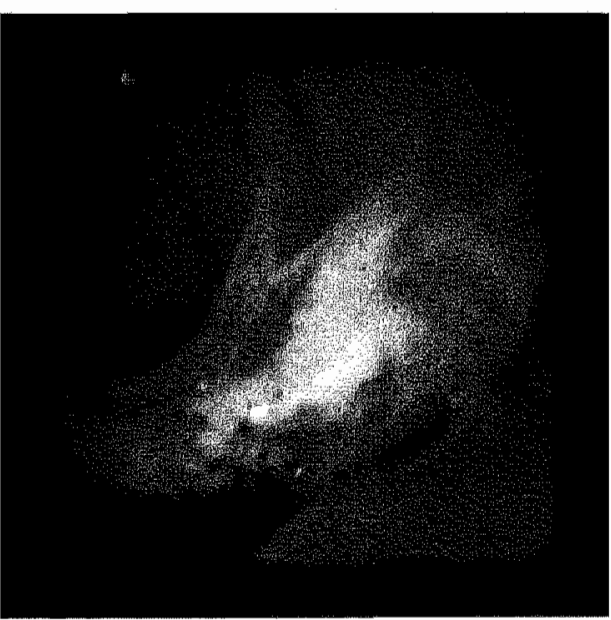

24. Groot ulcus in praestomaregio BI1-matig (PA : benign

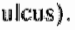




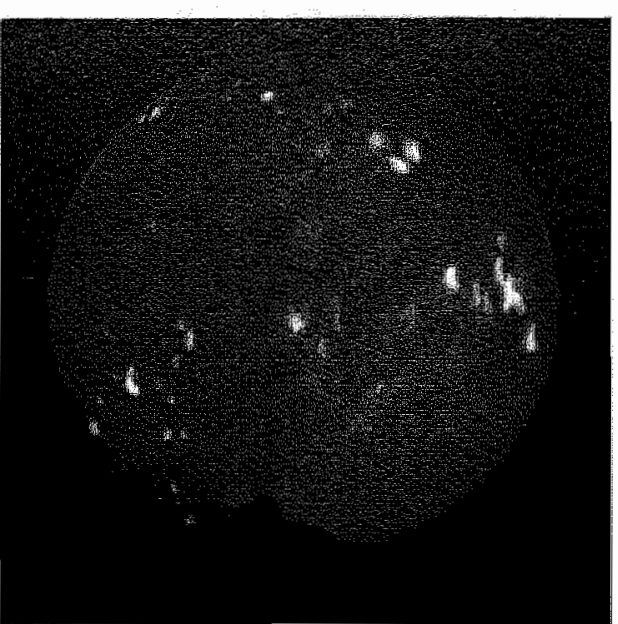

25. Klein poliepje corpus BIl-mag (PA: chronische ontstekingy.

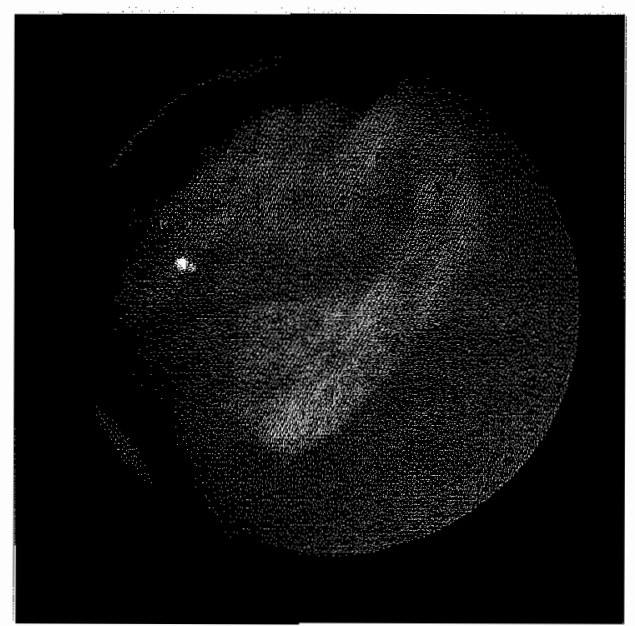

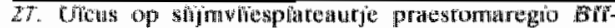
matag, stuspect woor chrcinoom (PA: geen maligne cellen) 79 jr.patt. bl. 44

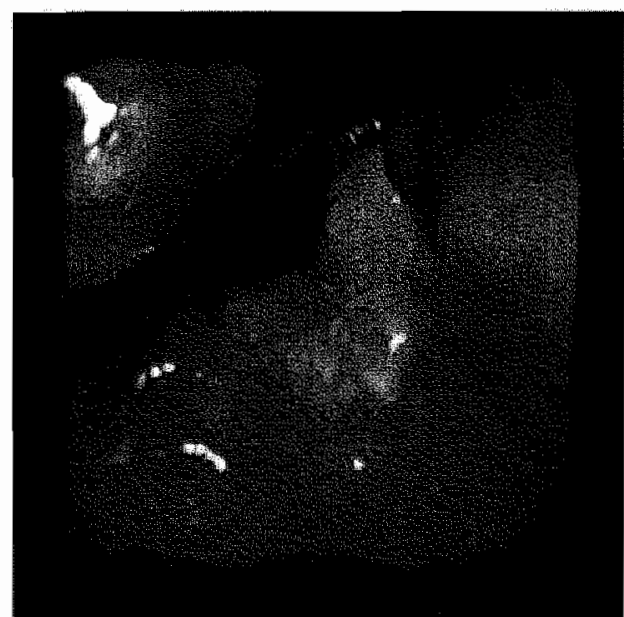

29. Proliferatict proces distale oesofagus (doorgroei cardiactrcinoom (3t1-naag), pat. 20 bl. 33.
26. Sli moliesflap woorwandijide corpus Bill-maag (PA: adenomateus weefsel met matige afypie). pat 9 bl. 51 .

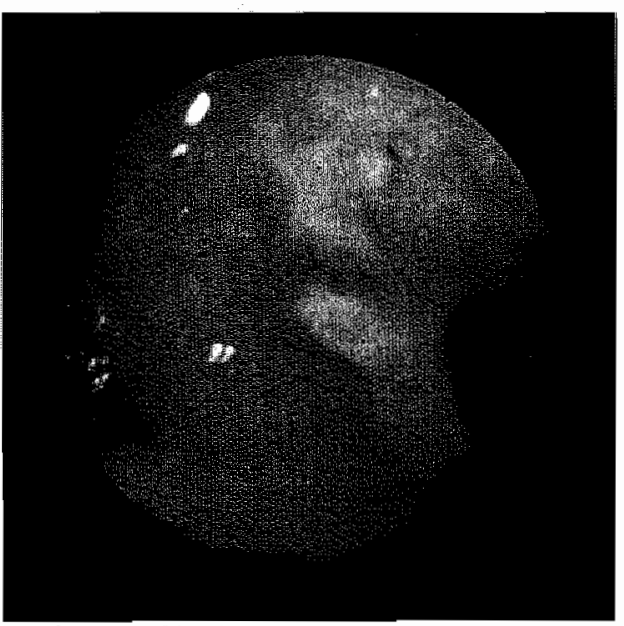

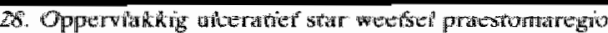
Bll-maag, wijzend op carcinoom (PA: carcinoom). pat. 7 b. 69 .

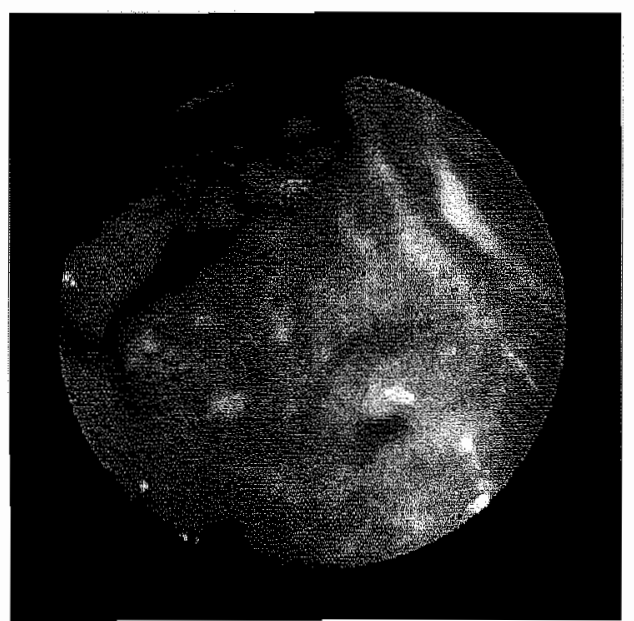

30. Geinfiltreerd weefsel grote curvatuurziijde stoma BIImaag, wizzend op carcinoon (PA: carcinoom). pat. $8 \mathrm{bl}$. 43. 


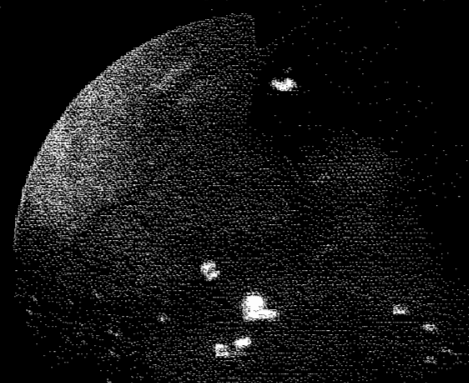

31. Proliferatief weetsel stomarand grote curvatunzijde BII-maag, wijzend op carcinoom (PA: carcinoom). pat. 13 bl. 33 .

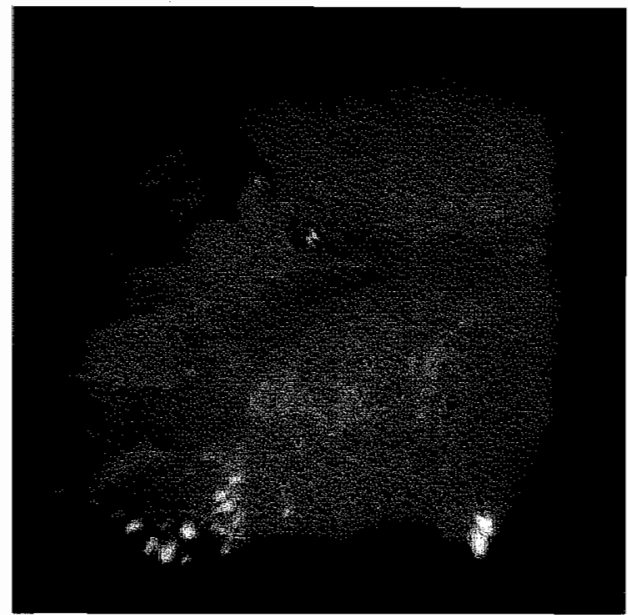

33. Diffuus geinfiltreerd weeflsel stoma BII-matag, wijend op carcinoom (P. carcinoom), pat. I d bl. 33 .

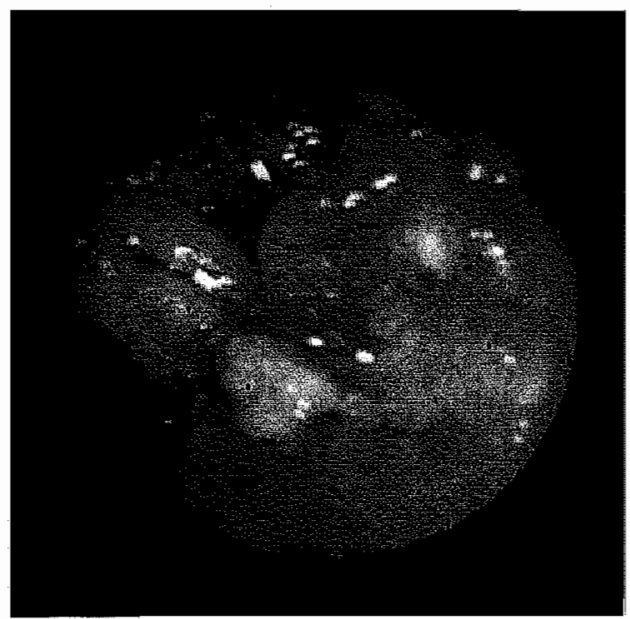

35. Ulceratice en proliferatief weefsel grote curvatuun corpus BII maag, wijend op carcinoom ( $\mathrm{PA}$ : carcinoom). part. 14 bll 43 .

34. Zeer forse plooi kleine curvatumirifide praestoma BUI. mag, wijzend op cathoom ( $\mathrm{P}$ : carcinoom) pat. 10. bl. 32 .

32. Onregelmatig ulceratief meefsel kinleine curvaluurzijde stoma BII-nuage, wijzend op carcinoom (PA carcinoom). pat. $10 \mathrm{bl} .43$.
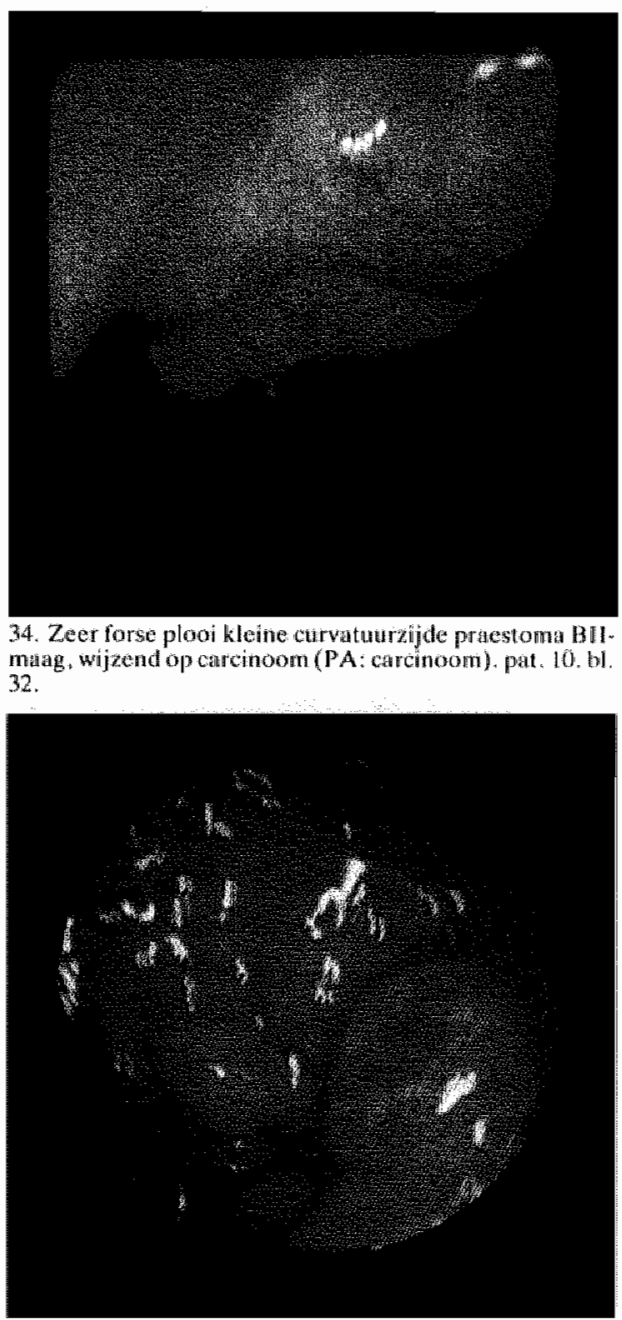

36. Polipoïd werdikte plooi, licht ulceratief, stomanceios Bll-maag, suspect voor carcinoom (PA: carcinoom) pat. d.d. juli 1983 , niet opgenomen in studic: 


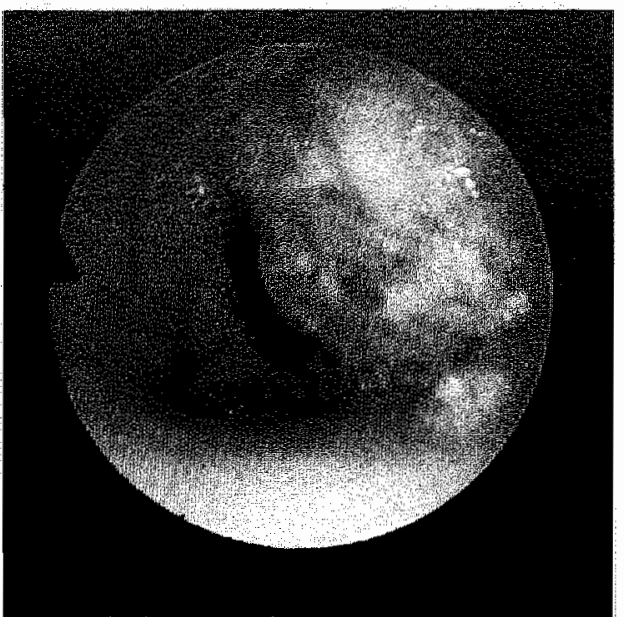

37. Polipoide tumor kleine curvatunrzijde corpus Bllmaga, wijzend op carcinoom (PA: chronische ontsteking). patt. 13 bi 43 .

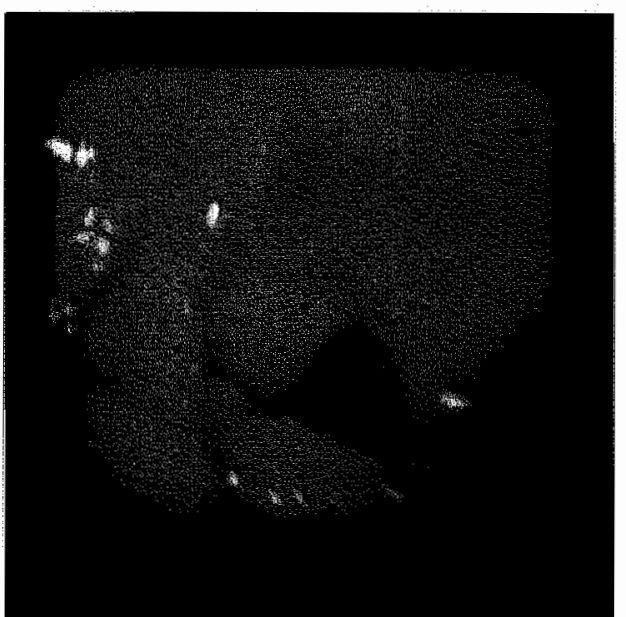

39. Geringe mabloeding biopsieplaats stomaregio But matag.

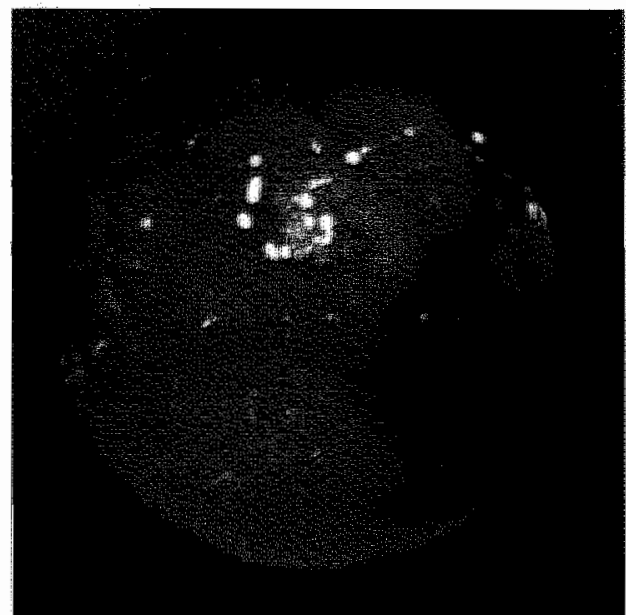

38. Dikwallig geinliltreerd, wittig, sanguinolent weofsel stomaregio Bll maja, wijend op carcinoom (PA: car cinoom). pat. 7 , b... 43 .

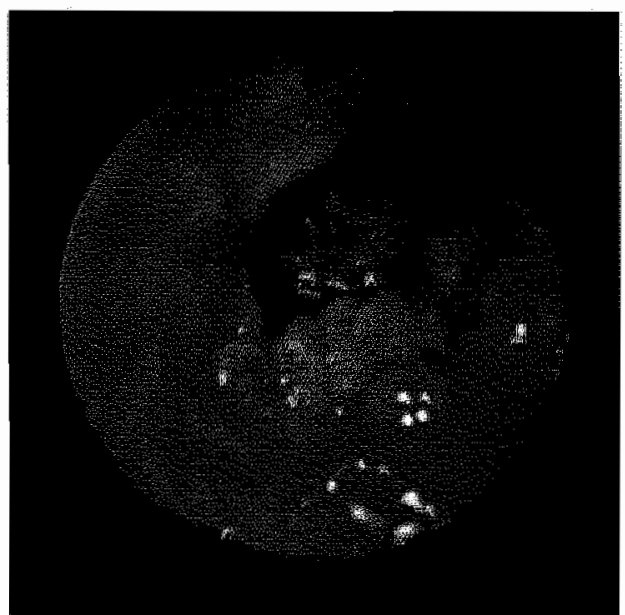

40. Nabloeding biopsiepladts stomaregio BH -mang 
9. Biopsie uit stoma:

Lichte atypie van het oppervlakkige epithes l hyperchromasie wan kernen en anisokaryose. Lamina propria: lichte chron. ontsteking met verwijding van opp. capillaren.

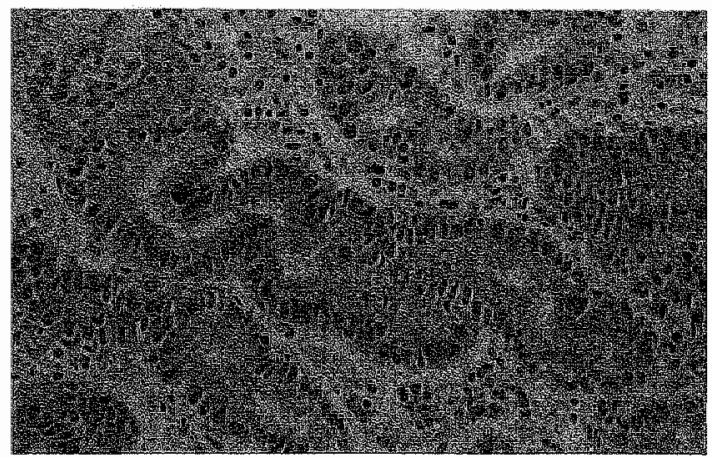

II. Biopsie uit stoma:

Matige atypie met anisokaryose, hyperchromasie wan de kernen, omregelmatige kernangschikking en meerdere mitosefiguren.

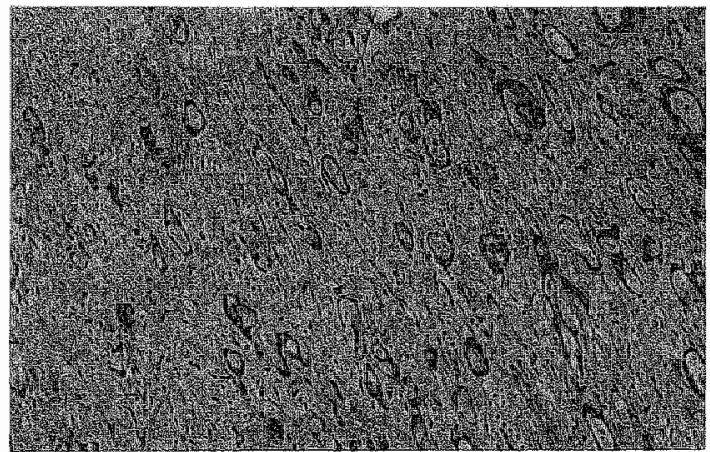

13. Biopsie uit stompcarcinoom:

Inteshinaal catcinoon: de grillig gevornde klierbuizen zäjr bekleed met atypisch epiheel en gelegen in cen fibreus stroma.

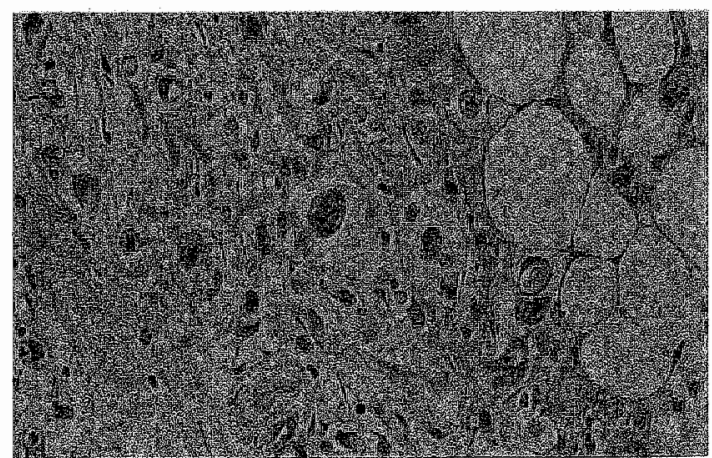

15. Biopsie uit stompcarcinoom:

Diffuus carcinoom: individuëte carcinooncellen temidden van en jil stroma. Een aantal zegelringeellen is te on derscheiden.

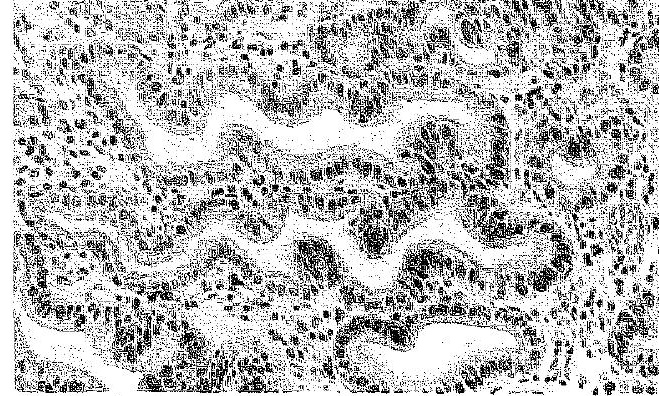

10. Biopsic uit stoma:

Lichte atypien de klierbuizen zijing grillig van worm en bevat enkele mitosen.

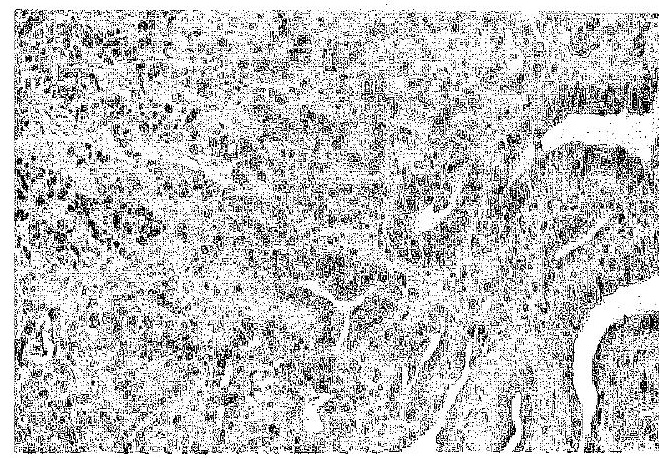

12. Biopsie uit stoma:

Ernstige afypie c. 9 . carcinoma in situ. Do hyperchromatis kernen liggen onordelijk gerangschikt in grillige klientbu De kernen zijn belangrijk groter dan normat.

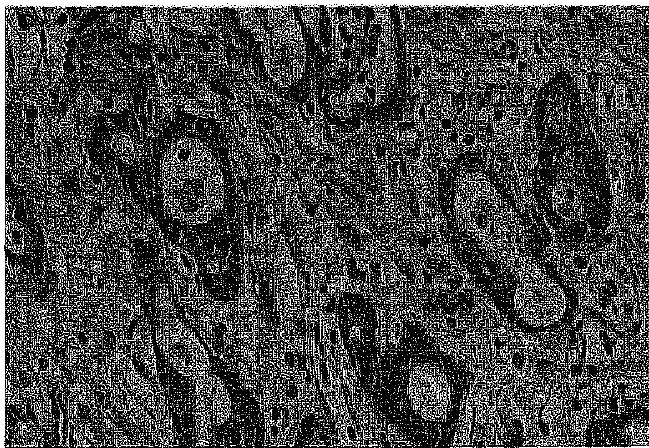

14. Biopsic uit wtompcarcinom:

Intestinat carcinoorn: de garillig gewormde klicrowzen beklecd met alypisch opitheel en gelegen in cen fib stroma (deckergroting van 13 ). 